\title{
De arbeidsmarkt naar opleiding en beroep tot 2006
}

Citation for published version (APA):

Cörvers, F., Diephuis, B. J., Golsteyn, B. H. H., Marey, P. S., \& Smits, W. (2001). De arbeidsmarkt naar opleiding en beroep tot 2006. Researchcentrum voor Onderwijs en Arbeidsmarkt, Faculteit der Economische Wetenschappen. ROA Reports No. 8 https://doi.org/10.26481/umarep.2001008

Document status and date:

Published: 01/01/2001

DOI:

10.26481/umarep.2001008

Document Version:

Publisher's PDF, also known as Version of record

\section{Please check the document version of this publication:}

- A submitted manuscript is the version of the article upon submission and before peer-review. There can be important differences between the submitted version and the official published version of record.

People interested in the research are advised to contact the author for the final version of the publication, or visit the DOI to the publisher's website.

- The final author version and the galley proof are versions of the publication after peer review.

- The final published version features the final layout of the paper including the volume, issue and page numbers.

Link to publication

\footnotetext{
General rights rights.

- You may freely distribute the URL identifying the publication in the public portal. please follow below link for the End User Agreement:

www.umlib.nl/taverne-license

Take down policy

If you believe that this document breaches copyright please contact us at:

repository@maastrichtuniversity.nl

providing details and we will investigate your claim.
}

Copyright and moral rights for the publications made accessible in the public portal are retained by the authors and/or other copyright owners and it is a condition of accessing publications that users recognise and abide by the legal requirements associated with these

- Users may download and print one copy of any publication from the public portal for the purpose of private study or research.

- You may not further distribute the material or use it for any profit-making activity or commercial gain

If the publication is distributed under the terms of Article $25 \mathrm{fa}$ of the Dutch Copyright Act, indicated by the "Taverne" license above, 


\section{De arbeidsmarkt naar opleiding en beroep tot 2006}

ROA-R-2001/8

Researchcentrum voor Onderwijs en Arbeidsmarkt

Faculteit der Economische Wetenschappen en Bedrijfskunde Universiteit Maastricht

Maastricht, november 2001 
Niets uit deze uitgave mag worden verveelwoudigd en/of openbaar gemaakt door middel van druk, fotocopie, microfilm, of op welke wijze ook, zonder voorafgaande schriftelijke toestemming van de directeur van het Researchcentrum voor Onderwijs en Arbeidsmarkt. In geval van overname van het data-materiaal moet telkens als bron worden vermeld 'Researchcentrum voor Onderwijs en Arbeidsmarkt' of 'ROA'. Van publicaties waarin gebruik wordt gemaakı van gegevens uit dit rapport ontvangen wij gaarne een exemplaar.

Hoewel de grootst mogelijke zorg is besteed aan de inhoud van dit rapport, kan het ROA in generlei opzicht verantwoordelijkheid op zich nemen voor eventuele onvolledigheden of onjuistheden.

Dit rapport maakt deel uit van het Project Onderwijs Arbeidsmarkt (POA). Dit project wordt gefinancierd door het Ministerie van Onderwijs, Cultuur en Wetenschappen, het Arbeidsbureau Nederland, het LDC Expertisecentrum voor Loopbaanvraagstukken en het Ministerie van Landbouw, Natuurbeheer en Visserij. 


\section{Inhoud}

Ten geleide 1

Resumé

$\begin{array}{ll}\text { Overzicht tabellen en figuren } & \mathrm{X} 1\end{array}$

Doel en opzet van de arbeidsmarktprognoses $\quad$ XV

1 De arbeidsmarkt in vogelvludnt $\mathbb{1}$

1.1 De verwachte arbeidsmarktontwikkeling I

1.2 Werkgelegenheidsontwikkeling naar bedrijfssector 4

1.3 Werkgelegenheidsontwikkeling naar beroepsklasse

1.4 Werkgelegenheidsontwikkeling naar opleidingsniveau 7

1.5 Toekomstige arbeidsmarktperspectieven naar opleidingsnivean 10

2 Ontwikkelingen op de arbeidsmarkt, 2001-2006 1.5

$\begin{array}{ll}2.1 & \text { Uitbreidingsvraag } \\ 2.2 & 1.3\end{array}$

2.2 Vervangingsvratag 17

2.3 Baanopeningen $\quad 22$

2.4 Arbeidsmarktinstroom 29)

3 De aansluiting tussen onderwijs en arbeidsmarkt 33

3.1 Huidige aansluitingsproblemen 33

3.2 Toekomstige arbeidsmarktperspectieven en knelpunten in de personeelsvoorziening nat opleiding 42

3.3 Toekomstige knelpunten in de personeelsvoorziening natr beroep

+ Het onlxenulte arbeidspotenticel

4.1 Inleiding 55

4.2 Ontwikkeling en kenmerken van cle potentiële lxerepsilevolking 58

4.3 Concurrentiepositie van het onbenut arlyeidspotentied

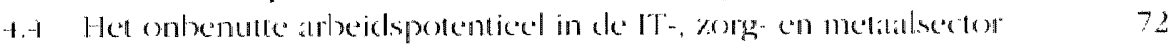

5 De amboudende krapte op de arbeidsmarkt 7t)

Biilage A. Enkele centrale begrippen 91

Billage B. Classificaties natar sector, beroep en opleding yo

Bijlage C. Verkrijghare arbeidsmarktinformatic per bedryjesector. beroepsgroep of opleidingstype 


\section{Ten geleide}

Met dit rapport wil het Researchcentrum voor Onderwijs en Arbeidsmarkt (ROA) inzich geven in de huiclige en de toekomstige arbeidsmarktsituatie van de verschillende beroepsklassen en opleidingscategorieën. Hierbij gaat de centrale aandacht uit naar de verwachte ontwikkelingen op de middellange termijn. Er is voor een tijdshorizon van vijf jaar gekozen, om een zo goed mogelijk beeld te kunnen geven van de arbeidsmarktsituatie bij afstuderen van degenen die thans aan het begin van hun studie staan. Deze informatie is van belang voor zowel hel geven van voorlichting atan degenen die aan een opleiding willen beginnen als het nemen van beleidsbeslissingen door instanties die betrokken zijn bij de aansluiting tussen het onderwijs en de arbeidsmarkt. De voorlichtingsfunctie wordt in het bijzonder vervuld door het LDC Expertisecentrum voor Loopbaanvraagstukken, die de arbeidsmarktinformatie van hel ROA verwerkt in zijn voorlichtingsproducten ten behoeve van loopbaanoriëntatie en begeleiding. Het voorliggende rapport is echter in het bijzonder bedoeld voor de beleidsontwikkeling van de overheid, de arbeidsvoorzieningsorganisaties, de sociale partners en hel onderwijsveld.

Het rapport is de zesde uitgave van het tweejatrlijkse overzicht dat het ROA malak in her kader van het Project Onderwijs-Arbeidsmarkt (POA). Hoewel het POA-informaticsysteem gegevens bevat op het aggregatieniveau van 127 beroepsgroepen en 104 opleidingstypen, spitsen de beschrijvingen en analyses in het rapport zich toe op de grote lijnen van de huidige en toekomstige arbeidsmarktontwikkelingen. Dit word gedatan op basis van de onderscheiden 11 beroepsklassen en 17 opleidingscategorieën. Wel wordi op verschillende plaatsen in het rapport verwezen naar opvallende ontwikkelingen ten aanzien van bepaalde beroepsgroepen en opleidingstypen. Ook is voor het eerst exen overzicht van de tabellen en figuren opgenomen aan het begin van het rapport. In bijlage B wordt een overzicht gegeven van de beknople en uitgebreicle classificatices nalar sector, beroep en opleiding. In bijlage C worde een volledig overzichl gegeven valn de arbeidsmarktinformatie die voor bedrifssectoren, beroepsgroepen en opleidingstypen beschikbatar is uit het POA-informatiesysteem. Deze informatic is niet meer \%als voorheen in een Statistische Bijlage verkriighatr, maar kan wel hij hel ROA bestedd worleden.

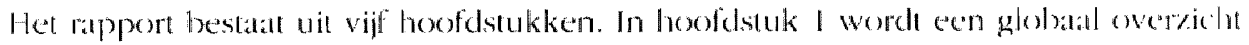
gegeven wan de ontwikkelingen die voor de periokle $2001-2006$ zijn te verwachlen op cle arbeidsmarkt. In hoofdlstuk 2 worden voor de jaren $2001-2000$ de meesil saillante arbeidsmarktontwikkelingen nar opleiding en beroep in beeld gebracht. In heoblatuk 3 staal de alanshluiting tussen onderwijs en arbeidlsmarki centralal. Het hoofdsuluk gatal eerst nader in op de actuele ansluitingsproblematick op de arlxeidsmarki. Vervolgens word ingegatan op de toekomstige arbeidsmarkiperspectieven voor scheolverlatlets on de conjuncturgeveeligheid wan de verwachte werkgelegenhesdsgesei. In hes hoofdstuk word ook veel alandacht besteed an de knelpunten in de personeclsworsicning natap opleiding en beroep die werkgevers kunnen verwacheen Daarbij worde tevens ingegatan op de substitutiemogetijkheden die zij hebloen tussen mensen mex ean versthillende opleidingsachtergrond. 
In hoofdstuk 4 wordt uitgebreid stilgestaan bij de omvang en samenstelling van her onbenutte arbeidspotentieel. Hierbij wordt nagegaan in welke mate het potentieel van werklozen en niet-participerenden is geslonken gedurende de jaren van hoogconjunctutur, en of dit potentieel kan bijdragen aan een verlichting van de verwachte aanhoudende krapte op de arbeidsmarkt in de komende jaren. Tevens wordt ingegaan op de vraag of werklozen en herintreders gezien hun opleidings- en ervaringsachtergrond kunnen concurreren met schoolverlaters en reeds werkenden. Hoofdstuk 5 begint met een algemeen overzicht van het percentage schoolverlaters, werkenden, werklozen en niet-participerenden waarvoor werkgevers naar verwachting knelpunten in de personeelsvoorziening zullen ervaren. Vervolgens wordt nader ingegaan op enkele factoren die samenhangen met de alanhoudende krapte op de arbeidsmarkt. De onderwerpen die hierbij worden aangesneden zijn de upgrading van opleidingseisen, de samenhang tussen de uitstroom van personeel en leeftijd, geslacht en arbeidsomstancligheden, de invloed van het voortijdig schoolverlaten op de arbeidsmarktinstroom, en de verwachte arbeidsmarktperspectieven van mensen die een post-initiële opleiding hebben afgesloten.

In het rapport wordt slechts in beperkte mate ingegaan op de gehanteerde onderzoeksmethoden, de gehanteerde classificaties, enz. Daarvoor wordt verwezen naar de specifieke werkdocumenten en research memoranda van het ROA. In het binnenkort uit te brengen werkdocument Methodiek arbeidsmarktprognoses en -indicatoren 20012006 word een totaloverzicht gegeven van de voor deze versie van het tweejaarlijkse rapport gebruikte methodieken. Er wordt aan het begin van dit rapport wel kort ingegaan op de gebruiksdoelen van de prognoses en een globaal overzicht gegeven van het gebruikte prognosemodel. Dalarnaasi worden in bijlage A enkele centrale begrippen nader omschreven met verwijzingen nat de publicaties warin over het desbetreffende aspect nadere informatie is te vinden. Bovendien verschijnt er vrijwel gelijktijclig met dit rapport de ROA-classificatiegicls, watarin uitgebreide overzichten worden gegeven van de namen en coderingen van de sectoren, beroepen en opleidingen die binnen POA gelameerd worden en de koppelingen tussen de classificaties van het Centraal Bureau voor de Staltistick (CIBS) en het ROA. Vermelelenswaardig is nog dat na afloop van de prognoseperiode het ROA de voorspelkwalitest van cle verwachte vraig- en aanbodontwikkelingen nat heroep en opleiding evalueert. Uit het latste evaluatierapport blijkl onder meer dat voor de prognoseperiode 1993-1998 in 52\% van de ongeveer 100 opleidingstypen de juiste van de viff mogelijke typeringen werd gegeven. Voor $83 \%$ van de opleidingstypen werd de juiste of de angrenzende typering voorspeld.

Aan het POA-projed word financieel bijgedragen door het Ministerie van Onderwijs. Cultur en Wetenschappen, het Arbeiclsbureau Nederland, het LDC Experisecentrum vorof loophatanvatagstukken en het Ministerie van Landbouw. Natumbeheer en Visserij. De projectleiding is in handen van dr. F. Cövers. Aan dit rappont en het bijlbehorende POA-inlormatiesystem is meegewerkt door dr L. Borghans. drs. B.J. Diephuis, S. Dijksman, drs. B. Golsteyn, prol. dr. A. de Grip, prof. dr. J.A.M. Heijke. R. Leclerca. drs. Ph.s. Matrey en drs. W. Smits.

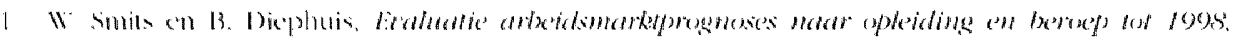

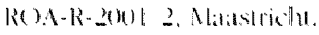


Onze dank gaat uit naar de leden van de begeleidingscommissie en de commissic van financiers voor hun deskundige en enthousiaste begeleiding van het project: Prof. dr. $\mathrm{H}$. Ganzeboom (voorzitter begeleidingscommissie, Rijksuniversiteit Utrech), drs. A. Bouman (Arbeidsbureau Nederland), mevr. drs. L. Brinkman (Ministerie van Economische Zaken, dhr. H. Daale (HES Amsterdam), dr. ir. F.Y. Dijkstra (Ministerie van Onderwijs, Cultuur en Wetenschappen), drs. M.G.K. Einerhand (Ministerie van Sociale Zaken en Werkgelegenheid), dhr. K. Koning (LDC Expertisecentrum voor Loopbaanvraagstukken), dr. P.W.C. Koning (Centraal Planbureau). ir. J.E.M. Lint (Ministerie van Landbouw, Natuurbeheer en Visserij), mevr. drs. J.G. van der Meer (Ministerie van Onderwijs, Cultuur en Wetenschappen), drs. M.A. Siers (Arbeidsbureau Nederland), drs. J. van der Valk (Centraal Bureau voor de Statistiek), dr. P.M. Veen (Ministerie van Onderwijs, Cultuur en Wetenschappen), dr. H.H. van der Velde (Ministerie van Onderwijs, Cultuur en Wetenschappen) en drs. J.P. Vosse (Organisaltie voor Strategisch Arbeidsmarktonderzoek), drs. P.H.J. Vrancken (Ministeric van Onderwijs, Cultuur en Wetenschappen) en dhr. C. Wielemaker (COLO).

Maastricht, november 2001

Prof.dr. J.A.M. Heijke

Directeur 


\section{Resumé}

\section{De arbeidsmarkt op macro-niveau tot 2006}

- Voor de periode 2001-2006 wordt op basis van prognoses van hel Centrat Planbureau een gemiddelde werkgelegenheidsgroei verwacht van 1.2\% per jaar (in personen), hetgeen beduidend is lager dan de $2,7 \%$ in de afgelopen periode $1990-$ 2000. De verwachte jaarlijkse uitstroom van werkenden over de prognoseperiode zal ten opzichte van de afgelopen periode slechts licht toenemen van $3.8 \%$ natu 4.1\%. De sterke daling van de werkgelegenheidstoename zorgt er voor dat per salcto het aantal baanopeningen anzienlijk zal dalen, van $6,5 \%$ gemiddeld per jaar in de afgelopen periode nat $5,3 \%$ in de prognoseperiode.

- De sectoren die het grootste deel van de werkgelegenheidsgroei voor hun rekening nemen, zijn de dienstensectoren bandel en reparatie, boreca en zakelijke dienstverlening, en kwartaire diensten (waaronder de gezondheidszorg). Bovendien wordt er, ondanks de teruglopende conjunctuur, een bovengemiddelde groei van de sector bouw en onroerend goed verwacht. Voor deze sectoren geld echter dat de hoge groeiciflers van de tweede helli van de jaren negentig valk meer dan gehalveerd worden. De werkgelegenheid zal natar verwachuing clalen in de scctoren

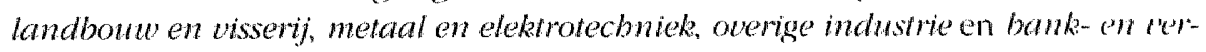
zekeringswezen. Met name voor de laatste sector wordt een overgang verwacht van de grote werkgelegenheidsgroei gedurende de afgelopen jaren nat een krimp van de werkgelegenheid in de prognoseperiode. Voor de sector energie worcli dairentegen verwacht dat de werkgelegenheid zich enigszins zal herstellen.

- De daling van de vragg naar arbeid op macro-niveau leidt niet tot een evenredige vermindering van de spanning op de arbeidsmarkt. omdal ook het anabxh van

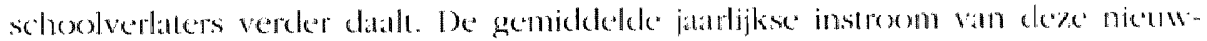
komers op de arbeidsmarkl daalt vanwege de ontgroening van de berocpsilevel-

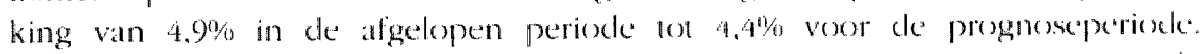
Aangezien cle claling van het atantal batanopeningen groter is dan de dalling valn de. arbeidsmarktinstroom van schoolverlaters, lijkt de spanning op de arbeidsmarkt in de periode 2001-2006 iets al te nemen ten opziche van de poriode 1996-2000) 10\% afnemende spanning op macro-niveau zegl echter nog weinig over de vrata- ats

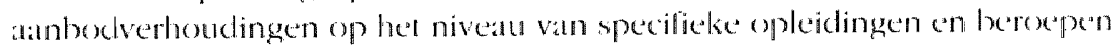

\section{Toekomstige arbeidsmarktperspectieven}

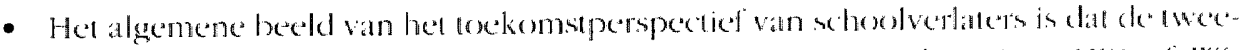

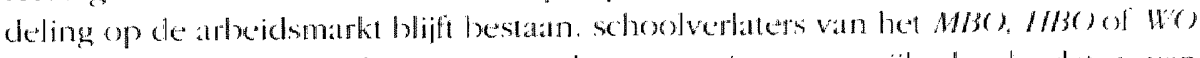

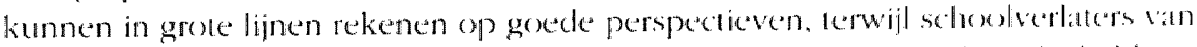

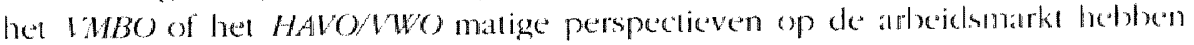
Rum $40 \%$ van het totat alantal schoolverlaters hecf een (zeer) goed perspectied terwijl het percentage schoolverlaters met een slech of matig perspectiel bijna coen groot is. Voor de viffaarsperiode van 2001 tot 2006 betekent dit dat 125.000 van ale 
ca. 340.000 schoolverlaters die jarlijks instromen op de arbeidsmarkt, een ongunstig arbeidsmarktperspectief hebben.

- Het zijn voornamelijk schoolverlaters van het $V M B O$ en het HAVO/VWO die met de gevolgen van de matige toekomstperspectieven, zoals werkloosheid, slechtere arbeidsvoorwaarden en werk onder het opleidingsniveau, worden geconfronteerd. Daarbij steekt het slechte arbeidsmarktperspectief voor VMBO economie extra ongunstig af als gevolg van de verwachte erg hoge arbeidsmarktinstroom van schoolverlaters met deze opleidingsachtergrond. Toch zijn de toekomstige arbeidsmarktperspectieven voor schoolverlaters van sommige opleidingstypen op VMBOniveau gunstiger, zoals bij $V M B O$ beveiliging.

- Het blijkt dat het toekomstig arbeidsmarktperspectief redelijk is voor de schoolverlaters die nagenoeg ongeschoold zijn. Deze schoolverlaters zijn voor een belangrijk deel 'drop outs' van het VMBO die slechts basisonderwijs hebben gevolgd. Het redelijke arbeidsmarktperspectief kan verklaard worden uit de hoge vervangingsvraag voor ongeschoolden ten gevolge van de doorstroom van werkenden met deze opleidingsachtergrond die alsnog een vervolgopleiding afronden. Bovendien is er sprake van een krimpende werkgelegenheid. Deze manifesteert zich met name in een hoge arbeidsmarktuitstroom op relatief jonge leeftijd, maar gaat niet ten koste van het arbeidsmarktperspectief van de schoolverlaters

- De perspectieven voor schoolverlaters van het $M B O$ zijn met name goed in de richtingen MBO landbouw en techniek en MBO economie. Het aantal schoolverlaters met een ongunstig arbeidsmarktperspectief binnen $M B O$ dienstverlening en gezondheidszorg is daarentegen aanzienlijk (40\%). Dit komt vooral door het relatief grote aantal schoolverlaters binnen deze opleidingscategorie van MBO sociaalcultureel en $M B O$ witerlijke verzorging, watarvoor een matig perspectief geldt. Datarentegen heelt bijvoorbeeld $M B O$ verpleging een zeer goed arbeidsmarktperspectief vanwege de lage arbeidsmarktinstroom en de hoge vervangingsvraig.

- Silnowlvetlaters van het HBO ol WO kunnen in het algemeen goede tor zeet goede abeidsmarktperspectieven verwachen. Voor schoolverlaters van het hoget onderwijs zipn er alleen voor enkele opleidingstypen van het $H B O$ slechte of matige

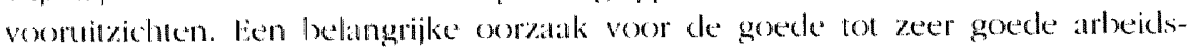
markiperspectieven is dall voor de hoger opgeleiden van zowel hel $H B O$ als hel WO de: arbeidsmarktinstrom geen gelijke tred houd mer de werkgelegenheidsgroei. Het verwachte gemiddelde alantal HBO-ers dat op de arletidsmarkt instroomt. blift met ongeveer 58.000 personen per jatar gedijk. Datrentegen dablt het alantal wo-ers

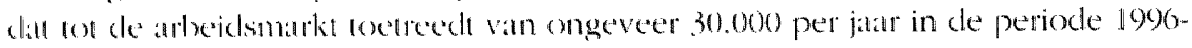
2000 natar ruin 20.0060 : ifgestudereden gemidedeld per jatar in periode $2001-2006$.

\section{Conjunctuurgevoeligheid van toekomstperspectieven}

- Vour ongeveer cen kwant van de schoolverlaters is het lockomstige arbeidsmarkiperspecticl omathankelijk van de conjuncturele ontwikkelingen. Deze schoolverlatlers heblen vectal een opleiding gerich op de zorgsector. matr er zijn eveneens schoolverlaters van opleidingstypen buten deze sector wiens batankansen 
nauwelijks onderhevig zijn aan conjuncturele fluctuaties, zoals MMBO administratie, bandel en mode, MBO milieu en groene numte. HBO bibliotheek en documentatie en WO theologie.

- Als de economie in een dal terechtkomt zal ruim eenderde deel van de schoolverlaters voor wie nu een gunstig perspectief op de arbeidsmarkt wordt voorzien, het risico van een forse verslechtering van de arbeidsmarktsituatie lopen. Het betrefi hier vooral schoolverlaters van vele technische en in mindere mate economische opleidingstypen die het meeste risico lopen. zoals o.a. MBO boum, MBO installatietechniek, HBO bouwkunde en WO bouwkunde, HBO civiele tecbniek en WO civiele techniek, HBO commerciële economie en WO bedrifskunde.

\section{Knelpunten in de personeelsvoorziening}

- Het spiegelbeeld van de arbeidsmarktperspectieven voor schoolverlaters zijn de toekomstige knelpunten in de personeelsvoorziening voor werkgevers. Ook hier komt de eerder genoemde tweedeling van de arbeidsmarkt duidelijk naar voren: er zijn vrijwel alleen grote tot zeer grote knelpunten in de personeelsvoorziening voor MBO'ers, HBO'ers en WO'ers. Deze knelpunten hebben betrekking op $40 \%$ van de schoolverlaters, terwijl voor maar liefst de helft van de schoolverlaters geen knclpunten op de arbeidsmarkt bestaan.

- De pedagogiscbe beroepen en de medische en paramedische beroepon geven de grootste toekomstige knelpunten in de personeelsvoorziening te zien. Dit wordi voornamelijk veroorzaakt door de hoge vervangingsvragg en de lage arbeidsmarktinstroom van schoolverlaters met een geschikte opleidingsachtergrond voot de $z^{2}$ beroepen. Dit betekent dat knelpunten in de personeelsvoorziening voor de beroepen in het onderwijs en de zorg de komende jaren het grootst blijven. Voor ck: agrarische beroepen, de transportberoepen en de verzorgende en dienstrertenende' beroepen worden daarentegen vrijwel geen knelpunten verwacht.

\section{Onbenut arbeidspotentieel}

- De omvang van het onbenut arbeidspotentieed van werklozen en nict-participerenden is tussen 1994 en 1999 gedald van 3,3 miljoen natr 2,8 miljoen mensen. Bowendien is ook de simenstelling van het onbenut arbeiclspolentient vanuil arbeidsmarktperspectief ten ongunste veranderd: het alandeel personen in hel onlonutte arbeidspotentieel dat beschikbatr is voor werk (ind. werklozen), is tussen 1994 en 1909 gedaald van $25 \%$ naar $17 \%$. Dit hangt wataschijnlijk voor cen |xelangrijk gecleelte samen mel de verbeterde conjunctuur sinds 1994, watardor degenen die het meest bereid waren om betald werk te verrichten daar oxk voor een belangrijk deel reeds in zijn geslatagd.

- Terwijl in 2000 de werkloze beropsbevolking minder dan $4 \%$ titmalkie van de beroepsbevolking, was dat in 1994 nog ruim $8 \%$. Het blijkt dat niet allecen led keserroir van werklozen meedeint op de golven van de conjunctum, matr dall helsellike geldt woor degenen die niet participeren op de arbeidsmarkt. Er is velelesende recken om ben daadwerkelijk als een "stille reserve" te bestempeten dic ten tijele van luom 
conjunctuur kan worden ingezet. Deze 'stille reserve" zal bij een eventuele overgang natr een rumere arbeidsmarkt mogelijk weer toenemen. De 'stille reserve' vergroot: derhalve de flexibiliteit van het arbeidsaanbod en het aanpassingsvermogen van de arbeidsmarkt.

- Vrouwen zijn oververtegenwoordigd onder de werklozen: ongeveer $60 \%$ van de werklozen is vrouw. Jongeren zijn met name onder de kortdurig werklozen sterk oververtegenwoordigd. Bij een tegenvallende conjunctuur lopen zij het risico langer werkloos te worden, walardoor hun kans op werk verder afneemt. Onder de nietparticiperenden die weliswat beschikbaar zijn voor dle arbeidsmarkt maar niet actief op zoek zijn nat betaald werk, zijn veel vrouwen van middelbare leeftijd. Meer dan de helft van de beschikbare niet-participerenden is lager opgeleid. De relatief grote groep van beschilkbare niet-participerenden in de leeftijdsklasse van 50 tot en met 64 jaar heeft, in combinatie met andere factoren als langdurige inactiviteit, een lage opleiding en geringe inspanningen voor het zoeken naar een baan. slechts een kleine kans op betaald werk. In de grote groep niet-participerenden die geen behoefte hebben aan betaald werk, zijn vrouwen, lager opgeleiden en personen uit de oudere leeftijdsklasse sterk oververtegenwoordigd.

- Hoewel het gemiddelde opleidlingsniveau van het onbenut arbeidspotentieel is gestegen tussen 1994 en 1999, is de achterstand qua opleidingsniveau ten opzichte van de werkenden even groot gebleven. In 1999 ligt het aandeel personen in hed onbenutte atbeidspotentieel dat minimaal een middelbare opleiding heeft afgesloten, met $45 \%$ beduidend lager dan de $72 \%$ voor de werkende beroepsbevolking. Dit betekent dat non-participatie vooral een zaak is van de lager opgeleiden.

- In alle opleidingsrichtingen daialt het onbenutte arbeidspotentieel als percentage van de potentiële beroepslbevolking naarmate het opleidingsniveau hoger is. Een verklaring hiervoor is dat de grotere investeringen in onderwijs cloor hoger opgeteiden en de grolewe 'opportunily cost' valn he" niel-werken voor hoger opgeleiden een extra 'prikkel' vou hen zijn om te werken. Datarnats baten opleidingsrichungen watatin relatied veel mannen eon opleiding hebben gevolgd, zoals landbouw en

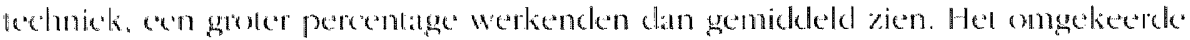
is he'l geval vour richtingen watrin relatief ved vrouwen exn opleiding hebben afgerond, zoals velzorging of clienswertenung en gezondheidszorg.

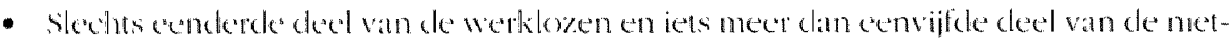

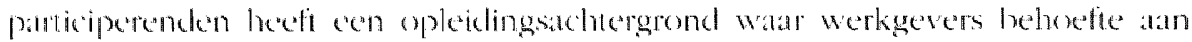

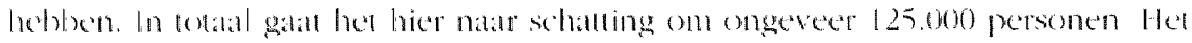
groxste decl van cke werklozen en beschikbare niet-participerenden dient echer crest om- of bijgesethookl te worden om voldoende productief te kunnen zijn Hun

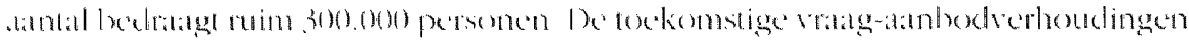

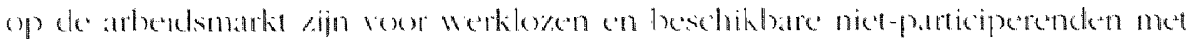

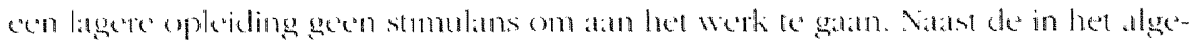

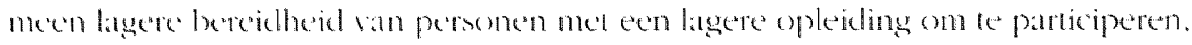

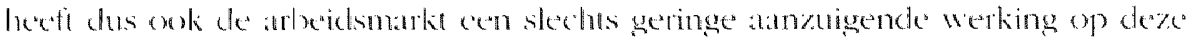
persenten om ke giduln participeren 
- Voor de arbeidsmarkt van beroepen in de IT-, zorg- en metaalsector geld dat werklozen en herintreders goed kunnen concurreren met schoolverlaters als ze een passende opleiding hebben en relevante werkervaring hebben opgedaan gedurende hun werkzame arbeidsleven. Langdurig werklozen en herintreders zonder relevante werkervaring hebben met name in de I'T en de zorgsector een erg slechte concurrentiepositie ten opzichte van schoolverlaters. Werkgevers hebben voor de meeste beroepen in de drie sectoren een voorkeur voor werkenden boven herintreders en langdurig werklozen. Waarschijnlijk speelt scholingsveroudering deze laatste twee groepen parten. Kortdurig werklozen zonder ervaring kunnen op de arbeidsmarkt echter wel redelijk concurreren met zowel schoolverlaters als reeds werkenden. Knelpunten in de personeelsvoorziening leiden in de zorgsector met name tot openstaande vacatures, terwij in de metalsecror en de IT eerder minder geschilite kandidaten worden aangenomen. Daar staat tegenover dat in de zorgsector herintreders met een geschikte vooropleiding en relevante werkervaring beter kunnen concurreren met reeds werkende kandidaten, hergeen de kans op knelpunten juist verkleint.

- Voor de IT-sector zijn er nog nauwelijks werklozen en niet-participerencien mer een goed aansluitende opleiding en relevante werkervaring. Voor de zorg- en de netalilsector lijkt er in eerste instantie genoeg aanbod te zijn uit het onbenutte arbeidspotentieel om te voldoen atn het verwachte vaagoverschot in 2006. Verreweg het grootste deel van dit onbenutte arbeidspotentieel is echter niet beschikbat voor de arbeidsmarkt. De inzet van werklozen en niet-participerenden die wet beschikhalar voor de arbeidsmarkt zijn, zal voor ruim een derde kunnen bijdragen aan het verminderen van het verwachte vraagoverschot in 2006 in de zorgsector: In de metialsector is dat voor ongeveer de helft van de verwachte tekorten. Bij deze controntittie van het potentiële arbeidsaanbod en het verwachte vraagoverschot moet echter rekening worden gehouden met de kwalitatieve discrepanties. Zo bestat het onlxenutte arbeidspotentieel van de zorg- en metaalsector voor een belangrijk deel uit personen met een VMBO-opleiding. Walarvor geen valagoverschor worde verwacht.

\section{Upgrading}

- Eén van cle betangrijke oorzaken van hel tekort an hoger opgeleiden is ke upgriat-

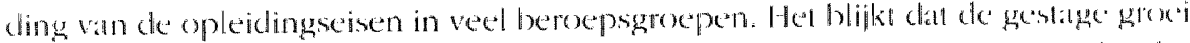

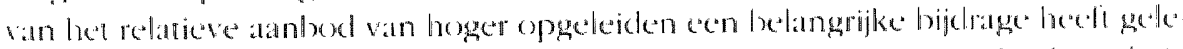

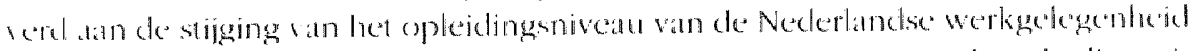

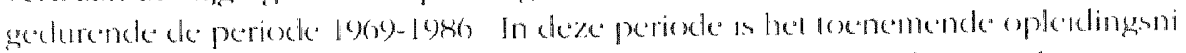

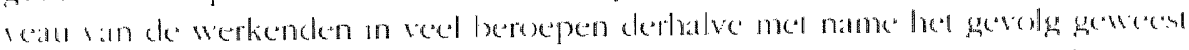

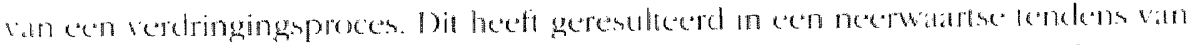

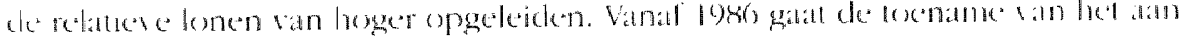

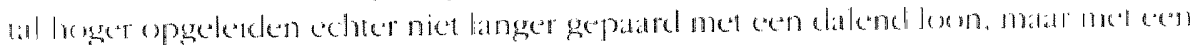

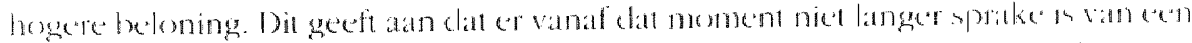

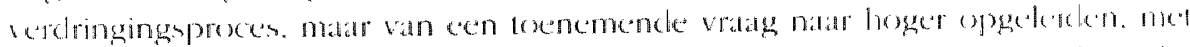

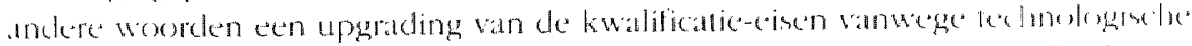

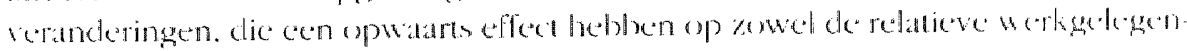
herd al de relatieve lonem van hoger opgeteiden 
- Naarmate bedrifssectoren meer uitgeven aan R\&D, wordi de vraag naar hoger opgeleiden groter ten koste van de vraag naar middelbaar en lager opgeleiden. Uitgaven aan ICT leiden daarentegen vooral tot een toename in de vraag naar middelbaar en hoger opgeleiden ten koste van lager opgeleiden en ongeschoolden. De snelheid van het upgradingsproces wordt met name bepaald door de diffusie van technologische vernieuwingen en de mede daaraan gerelateerde organisatorische veranderingen. Historisch gezien zijn R\&D-uitgaven aanmerkelijk meer variabel dan ICT-uiggaven en vormen derhalve de belangrijkste oorzaak van veranderingen in de snetheid van het upgradingsproces. Met name de verwachte verhoging van de R\&Duitgaven zal de komende jaren bijdragen aan een hogere snelheid van het upgradingsproces.

\section{Post-initieel onderwijs}

- Van 2001 tot 2006 zullen nar verwachting in totaal bijna 1,7 miljoen schoolverlaters tol de arbeidsmarkt toetreden. Van deze schoolverlaters is ca. $75 \%$ afkomstig uit het initiële en ca. $25 \%$ uit het post-initiële onderwijs. Het post-initiële onderwijs heeft met name een hoog aandeel in de totale arbeidsmarktinstroom van het HAVO/VWO en de drie opleidingscategorieën binnen het $M B O$.

- Een groot deel van de schoolverlaters met als hoogst voltooide opleiding basisonderwits, VMBO theorie of HAVO/VWO gaat een post-initiële vervolgopleiding volgen na cle instroom op de arbeidsmarkt. Een cleel van deze schoolverlaters is eerder in de schoolkopbaan niet succesvol geweest in het afronden van de initiële vervolgopleiding. Het post-initiële onderwijs biedt aan deze 'drop outs' een tweede kans terwij] zij reeds op de arbeidsmarkt participeren.

- Schoolverlaters krijgen door het volgen van een post-initiële opleiding een beter lockomstperspectief dan de sichoolverlaters die een initiële opleiding hebben gevolgd. Een verklaring hiervoor zou kunnen zijn dau de post-initiële opleidingen worden bekostigd door individuele personen en bedrijven. watrdoor bij de beslissing valn het volgen van een dergelijke opleicling een betere kosten-baten afweging wordel gemanki dan bij de initièle opleidingen. Dit impliceert dat de post-initiële opleidingen gemiddeld mest markteonform zijn dan de initiële opleidingen. 


\section{Overzicht tabellen en figuren}

Figuur 1 Globale opzet prognosemodel

\section{Hoofdstuk 1}

Tabel 1.1 Arbeidsmarktontwikkeling 1996-2000 en de prognoses voor de periode 2001-2006, gemiddelde jaarlijkse percentages

Tabel 1.2 Ontwikkeling van het aantal werkenden per bedriffsector 1996-2000 en de uitbreidingsvraag naar bedrijfssector 2001-2006, gemiddelde jaarlijkse percentages

Tabel 1.3 Ontwikkeling van het aantal werkenden per beroepsklasse 1996-2000 en de uitbreidingsvraag naar beroepsklasse 2001-2006, gemiddelde jaarlijkse percentages

Tabel 1.4 Ontwikkeling van het aantal werkenden per opleidingsniveau 1996-2000 en de uitbreidingsvraag naar opleidingsniveau 2001-2006, gemiddelde jaarlijkse percentages

Tabel 1.5 Componenten van de vraagontwikkeling per opleidingsniveau (netto-effecten ${ }^{*}$ ), 2001-2006

Tabel 1.6 Uitbreidingsvraag, vervangingsvraag en arbeickmarktinstroom (gemiddelde jaarlijkse percentages) en de daaruit volgende toekomstige arbeidmarktperspectieven per opleidingsniveau, 2001-2006

Tabel 1.7 Percentage schoolverlaters waarvoor een goed tot zeer goed arbeidsmarktperspectief wordt verwacht per opleidingsniveau. 2001-2006

\section{Hoofdstuk 2}

Tabel 2.1 Uitbreidingsvraag naar beroepsklasse, in aantal en als percentage van de werkgelegenlheid, 2001-2006

Figuur 2.1 Uitbreidingsvrag nat beroepsklasse, prognose 2001-2006 en realisatie 1996-2000. als gemiddeld jiarlijks percentage van de werkgelegenheid

Tabel 2.2 Uitbreidingsvraag natr opleidingscalegoric. in alantal en als percentage van de werkgelegenheid, $2001-2006$

Figuur 2.2 Uitbreidingsvratg natr opleidingscategorie, prognose 2001-2006 en realisatie 1996-2000, als gemiddeld jarlijks percentage van de werkgelegentueicl

Talbel 2.3 Verrangingsvalag nata beroepskbasse, in alantal en als percentage van de werkgelegenheid, 2001-2006

Figutr 2.3 Vertangingsvraag nat beroepsklasse. prognose 2001-2006 en realisatie 1996-2000, als gemidelekd jaarlijks percentage van de werkgelegenheid

Taldet 2.-1 Vervangingsvratag natr opleidingscategorice, in alatal en als percentage van de werkgelegenheid, 2001-2006

Figuur 2. 4 Venangingsvrag natr opleddingscategorie. prognose $2001-20000$ 
en realisatie 1996-2000, als gemiddeld jaarlijks percentage van de werkgelegenheid

Tabel 2.5 Baanopeningen naar beroepsklasse, in aantal en als percentage van de werkgelegenheid, 2001-2006

Figuur 2.5 Baanopeningen naar beroepsklasse, prognose 2001 en realisatie 1996-2000, als gemiddeld jaarlijks percentage van de werkgelegenheid

Tabel 2.6 Baanopeningen naar opleidingscategorie, in aantal en als percentage van de werkgelegenheid, 2001-2006

Figuur 2.6 Baanopeningen naar opleidingscategorie, prognose 2001-2006 en realisatie 1996-2000, als gemiddeld jaarlijks percentage van de werkgelegenheid

Tabel 2.7 Instroom op de arbeidsmarkt naar opleidingscategorie, in aantal en als percentage van de werkgelegenheid, 2001-2006

Figuur 2.7 Arbeidsmarktinstroom naar opleidingscategorie, prognose 2001-2006 en realisatie 1996-2000, als gemiddeld jaarlijks percentage van de werkgelegenheid

Tabel 2.8 Arbeidsmarktinstroom van personen van het post-initiële onderwijs per opleidingscategorie, percentage van de totale arbeidsmarktinstroom, 2001-2006

Hoofdstuk 3

Tabel 3.1 Werkloosheidspercentage beroepsbevolking naar opleidingsniveau, 1994 en 2000

Tabe] 3.2 Werkloosheidspercentage schoolverlaters naar opleidingscategorie, 1998 en 2000

Tabel 3.3 Procentuele gemiddelde jaarlijkse stijging van het gemiddelde bruto maandloon voor schoolverlaters tussen 1998 en 2000 natr opleidingscategorie*

riguur 3.1 Percuntage deeltijdarbeid tegenover percentage flexibel werk onder schoolverlaters, per opleidingscattegorie*, 2000

Figuur 3.2 Werklox sheidspercentage tegenover percentage onderbenutting onder sichoolverlaters, per opleidingscattegorie*. 2000

lïguur 3.3 Percentage onderbenutting tegenover werk buiten eigen vakrichting onder schoolverlaters. per opleidingscategorie*. 2000

Figunar 3.4 De arbeidsmarktsituatie van schoolverlaters in 2000 natar zes dimensies per opleidingscategorie"

Talbel 3.4 Inclicator toekonstige atbeidsmatrktperspectieven (ITA) en Indicator toekomstige knelpunten in de personeelsvoorziening natr opleiclingseategorie (ITKP)

Taldel 3.5 Pereentige schoolverlaters naar verwach arbeidsmalktperspectief in 2000. per opleiclingscalegorie

1:10el 3.6 Percentage shoolverlaters natar verwachte knelpunten in de persone elsworkiening in 2006, per opleidingsaltegorie

Tahed 3.7 Percentage schoolverlaters met verwacht arbeidsmarktperspectief 101 2006 in relatie tor de conjuncturgevoeligheid van de werkgelegenheid

Talyel is indicator toekomstige knelpunten in de personeelswoorziening 
Tabel 3.9 Percentage werkenden naar de typering van de verwachte knelpunten in de personeelsvoorziening naar beroepsgroep (ITKB) in 2006

Tabel 3.10 Percentage werkenden waarvoor knelpunten in de personeelsvoorziening tot 2006 worden verwacht in relatie tot de substitutiemogelijkheden van personeel voor werkgevers

\section{Hoofdstuk 4}

Figuur 4.1 Onbenut arbeidspotentieel naar afnemende bereidheid om betaald werk te verrichten

Tabel 4.1 Onbenut arbeidspotentieel, excl. studenten en scholieren

Tabel 4.2 Onbenut arbeidspotentieel, excl. studenten en scholieren, aandeel met minimaal MBO-niveau of hoget

Tabel 4.3 Werkenden, werklozen en beschikbare niet-participerenden van de potentiële beroepsbevolking, excl. studenten en scholieren, naar achtergrondkenmerken, 1999

Tabel 4.4 Niet-beschikbare niet-participerenden van de potentiële beroepsbevolking, excl. studenten en scholieren, naar achtergrondkenmerken, 1999

Tabel 4.5 Arbeidsmarktpositie onbenutte arbeidspotentieel (exclusief scholieren en studenten) als percentage van de potentiële beroepsbevolking naar opleidingscaregorie, gemiddelde 1998-1999

Tabel 4.6 De kans om te worden verkozen boven een werkende kandidaat met gelijke opleiding en ervaring"

Tabel 4.7 De kans dat werklozen en herintreders met relevante werkervaring worden verkozen boven een tien jaas jongere schoolverlater ${ }^{*}$

Tabel 4.8 De kans dat werklozen en herintreders met een goed aansluitende opleiding en relevante werkervaring worken verkozen boven een tien jaar jongere schoolverlater met een niet goed aansluitende opleiding*

Tabel 4.9 De kans dat werklozen en herintreders zonder relevante werkervaring worden verkozen boven een vijf jalar jongere schoolverlater met een gelijke opleiding"

Tabel 4.10 Het effect van knelpunten in de personeelsvoorziening en cle kwaliteit van het arbeidsaanbod op de selectiecriteria

Tabel 4.11 Belangrijkste opleidingstypen in cle 1T-, zorg- en metaalsector

Tabel 4 12 Aandeel werklozen en niet-participerenden in cle potentiële beroepsbevolking (exclusief studenten en scholieren) voor drie sectoren. naar opleidingsniveau, gemiddelde 199k-1999

Tabel 4.13 Aantal werklozen en niet-participerenden mel een geschikte opleiding matr zonder relevante werkervaring in relatic tot het verwachte vraagoverschot in de IT-, zorg- en metaalsector, gemiddelde 1998-1999)

Tabel +14 Beroepsgroepen in de IT-, zorg-en metaalsector walar werklozen en herintreders relevante werkervaring kunnen 
Tabel 4.15 Aantal werklozen en niet-participerenden met een geschikte opleiding én relevante werkervaring in relatie tot het verwachte vraagoverschot in de IT-, zorg- en metaalsector, gemiddelde 1998-1999

\section{Hoofdstuk 5}

Tabel 5.1 Percentage van de schoolverlaters en de potentiële beroepsbevolking waarvoor werkgevers naar verwachting met (vrijwel) geen of juist (zeer) grote knelpunten in de personeelsvoorziening zullen worden geconfronteerd in 2006

Tabel 5.2 Vrouwen en ouderen (50-64 jaar) naar beroepsklasse, als percentage van de werkgelegenheid, gemiddelde 1999-2000. en uitstroom, gemiddeld jaarlijks percentage van de werkgelegenheid, 2001-2006

Tabel 5.3 Voorkomen van arbeidsomstandigheden naar beroepsklasse, 1998

Tabel 5.4. Arbeiclsmarktinstroom van voortijdig schoolverlaters naar hoogste voltooide opleidingstype, als gemidcleld percentage van totale jaarlijkse arbeidsmarktinstroom, 2001-2006

Tabel 5.5 Gediplomeerde schoolverlaters van het post-initiële vervolgonderwijs naar vooropleiding, gemiddeld jaarlijks, 2001-2006

Tabel 5.6 Indicator toekomstig arbeidsmarktperspectief van schoolverlaters met post-initiële opleiding ten opzichte van hun vooropleiding, 2001-2006

Tabel 5.7 Indicator toekomstig arbeiclsmarktperspectief van schoolverlaters met cen post-initiële ten opzichte van een initiële opleiding, 2001-2006 


\section{Doel en opzet van de arbeidsmarktprognoses}

\section{Doel}

Dit rapport van het Researchcentrum voor Onderwijs en Arbeidsmarkt (ROA) biedt een overzicht van de huidige en toekomstige ontwikkelingen op de Nederlandse arbeidsmarkt in de periode 2001-2006. Het gepresenteerde overzicht heeft als doel inzicht te verschaffen in de actuele situatie en de prognoses van beroepen en opleidingen op de arbeidsmarkt. De prognoses worden elke twee jar herhaald voor een nieuwe periode van vijf jaar:

Een belangrijke doelgroep van de prognoses wordt gevormd door jongeren die voor de keuze van een (vervolg)opleiding staan. De prognoseresultaten stellen hen in staat hun keuze te funderen op de arbeidsmarktperspectieven die de verschillende opleidingen bieden op de middellange termijn. Deze voorlichtingsfunctie wordt in het bijzonder vervuld door het LDC Expertisecentrum voor Loopbanvraagstukken. Daarnaast is de geboden informatie bedoeld voor het onderwijsbeleid. Daarbij kan vooral gedach worden aan onderwijsinstellingen en hun financiers die overwegen nieuwe opleidingen te beginnen of bestaande aan te passen. Een derde, en steeds belangrijker wordende, doelgroep zijn de werkgevers voor wie de prognose-uitkomsten aanwijzingen geven waar zich in de toekomst problemen in de personeelsvoorziening zullen voordoen, zodat zij hierop kunnen anticiperen. In de vierde plats zijn de arbeidsmarktprognoses bedoeld voor het arbeidsvoorzieningsbeleid. Met name voor het in dit verband gevoerde scholingsbeleid kunnen de prognoses een belangrijke signaalwerking helsben. Daarbij moet wel de kanttekening worden gemaakt clat de scholing van werkzoekenden doorgaans een kortere doorlooptijd heeft dan de opleidingen in het initiële onclerwijs. Daarom worden bijvoorbeeld in het Regionaal Arbeidsmarkt Informatiesysteem Limburg ( $R A L L$ ), dat onder meer is ontwikkeld ten behoeve van het scholingsbeleid van Arbeidsvoorziening Limburg, korte-lemijn arbeidsmanktprognosses opgesteld ${ }^{2}$. Ten slonte zijn cle prognoses bedoetd voor het arbeidsmarkbeleid in rume zin. Datarbij kan gedacht worden atan o.a. het doelgroepenbeleid, het heleid gericht op hed vergroten van de arbeidsmarktparticipatie en het arbeidsmaldibeleticl ten alanzien van de onderkant van de arbeidsmarki.

\section{Prognosemodel}

Bij het maken van de arbeidsmarklprognoses is uitgegaan van een stroomcijler-alanpak. Bij deze alanpak worden prognoses gemaka van de stromen van en nata de arlerids markt in een bepatale toekomstige periode. Deze benadering heeli als verordecel dall de processen in kara worden gebracht die van belang zijn voor de onlwikkeling van valag

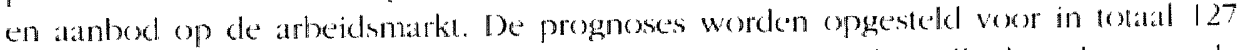
beroepsgropen en 104 opleidingstypen. gespreid over de volle breede valn de arbeidsmatkt. Van belang is dat de prognoses, en ook de overige opgenomen

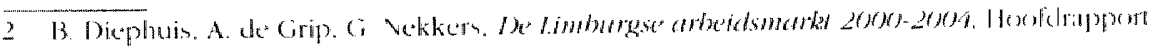
ROA-R-zom 1. Matastrieht 
arbeidsmarktgegevens, in dit rapport worden gepubliceerd op het niveau van 11 beroepsklassen en 17 opleidingscategorieèn. De onderliggende beroepsgroepen en opleidingstypen zijn opgenomen in bijlage B van dit rapport.

Figuur I

\section{Globale opzet prognosemodel}

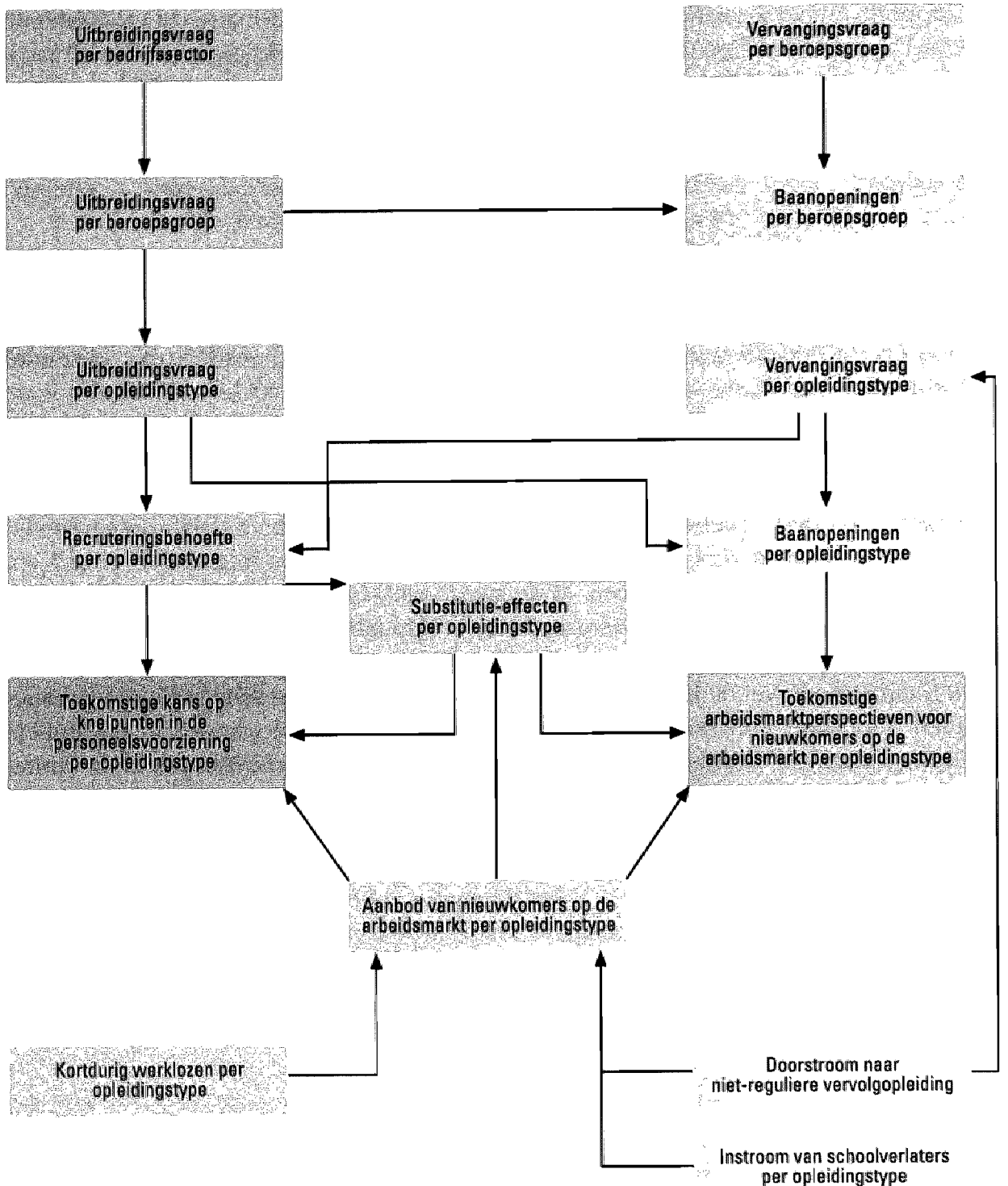

Piguur I geefteen seluematisch overzicht vin hel prognosemodel Een stromgrootheid

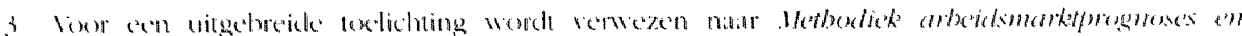

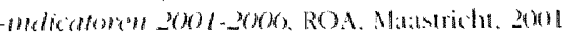


die van belang is voor de vraagzijde van de arbeidsmarkt is de uitbreidingsvraag, die de ontwikkeling weergeeft van de werkgelegenheid in een bepaalde beroepsgroep of voor een bepaald opleidingstype. De prognoses van de uitbreidingswraag zijn gebaseerd op de werkgelegenheidsprognoses voor bedriffssectoren van het Central Planbureau (CPB). Hierbij is uitgegaan van het zogenaamde 'Global Competition scenario' in een lange-termijnverkenning van het $\mathrm{CPB}^{*}$. De keuze voor dit scenario in plaats van één van de twee overige scenario's ('Divided Europe' en 'European Coordination') is ingegeven door de constatering dat de economische en arbeidsmarktontwikkelingen sinds 1997 het meest overeenkomen met dit scenario. Global Competition gat uit van een grote technologische ontwikkeling en een sterke intemationalisering. Tevens spelen in dit scenario het marktmechanisme en de grote economische dynamiek in de vorm van liberalisatie, deregulering en felle concurrentie, een belangrijke rol. Een andere karakteristiek van Global Competition is een soberdere inrichting van de verzorgingsstat met een overheid die zich toelegt op de uitvoering van haar klassieke taken, zoals onderwijs, infrastructuur en openbaar bestuur. In afwijking van dit lange-termijnscenario is voor de prognoses van de uitbreidingsvraag voor 2001 en 2002 gebruik gemaakt van het Centraal Economisch Plan 2001 (CEP) van het CPB. Door het gebruik van deze kortetermijnprognoses wordt het gehanteerde lange-termijnscenario gecortigeerd met de meer recente inzichten in de groeiverwachtingen van het CEP.

In aansluiting op de prognoses van de uitbreidingsvraag voor bedrijfssectoren worden door het ROA prognoses gemaakt van de verschuivingen in de beroepenstructuur binnen de onderscheiden bedrijfssectoren. Hierdoor kan er rekening gehouden worclen met het feit dat binnen een bedriffssector bepaalde beroepsgroepen zich sneller ontwikkelen dan andere. Vervolgens wordt bepaald welke implicaties de voorspelde groei van de verschillende beroepsgroepen heeft voor de uitbreidingsvraag per opleidingstype. Hierbij wordt rekening gehouden met het optreden van verschuivingen in de opleidingenstructuur binnen beroepsgroepen. De uitbreidingsvraag per opleidingstype heeft betrekking op het aantal personen met een bepaalde opleidingsachtergrond, dat werkgevers zouden willen annemen om te kunnen voorzien in een grotere vaag natar goederen en diensten. De feilelijke ontwikkeling van het aantal werkenden per opleidingstype zal hier doorgaans van afwijken door de, mede door de ontwikkeling van hed arbeidsaanbod, veranderende schaarsteverhoudingen en de als gevolg clatrvith optredende substitutieprocessen.

Natast uitbreidingsvraag is er op de arbeidsmarki sprake van verronghgsonatag door - al dan niet vervroegde - pensionering, arbeidsongeschiktheid, tijclelijke terugtreding valn de arbeidsmarkt, beroepsmobiliteit, ed. Fr word overigens alleen van vervangingsvratag gesproken woor zover het vertrek van een werknemer ook daadwerkelijk heidt to vraag natr een nieuwkomer Als het vertrek van een arbeidskrach geloruikt word om een werkgelegenheidskrimp te effectueren, is er geen sprake van vervangingsvralag. Deze utstroom is immers niet relevant voor nieuwkomers. 1)il belekent dal nict de volledige arbeidsmarktuitstroom daadwerkelijk leidt tot vervangingsvratag

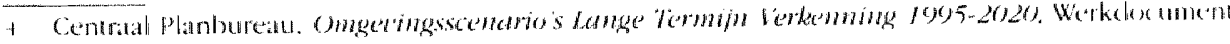
vo. $8 \%$. Den Hage jog 
Bovendien is er een belangrijk verschil tussen de vervangingsvraag per beroepsgroep en per opleidingstype. De beroepsmobiliteit is namelijk wel van invloed op de vervangingsvraag per beroepsgroep, maar heeft geen effect op de vervangingsvraag per opleidingstype. Het veranderen van beroep heeft immers geen gevolgen voor de opleidingsstructuur van de werkgelegenheid. Daarentegen kan een werkende door het aftonden van een vervolgopleiding in feite 'uitstromen' naar een ander opleidingstype. In dat geval is er sprake van een vervangingsvraag bij het opleidingstype waartoe de vooropleiding van deze werkende wordt gerekend.

Bij toename van de werkgelegenheid vormen de uitbreidingsvraag en de vervangingsvraag tezamen de baanopeningen voor nieuwkomers op de arbeidsmarkt. Bij krimpende werkgelegenheid kan er alleen sprake zijn van baanopeningen uit hoofde van vervangingsvraag.

Tegenover de totale vraag naar nieuwkomers staat het verwachte aanbod van nieuwkomers, dat bestaat uit de toekomstige arbeidsmarktinstroom van scboolverlaters en de doorstroom naar een ander opleidingstype vanwege het afronden van post-initiële vervolgopleidingen in de prognoseperiode en het nog boven de markt zwevende aanbod van kortdurig werklozen an het begin van deze periode. Verondersteld wordt dat langdurig werklozen, die langer dan een jar op zoek zijn naar werk, geen serieuze concurrenten meer vormen voor schoolverlaters. De prognoses van de instroom van schoolverlaters op de arbeidsmarkt hebben als uitgangspunt de Referentieraming 2001 van het Ministerie van Onderwijs, Cultuu' en Wetenschappen met betrekking tot de verwachte uitstroom uit het initiële onderwijs. Door het ROA zijn deze prognoses nader verbijzonderd en aangevuld met prognoses van de doorstroom natar het post-initiële onderwijs.

Door de verwachte vraag- en aanbodstromen met elkaar te confronteren word per opleidingstype een indicatie verkregen van de toekomstige arbeidsmarktperspectieven voor nieuwkomers op cle arbeidsmarkt. De watade van de Indicator Toekomstige Arbeidsmarktperspectienen (ITA) geeft alan welke vraag-aanbod-discrepantie er per opleidingstype te verwachen is. Als het arbeidsambod kleiner is dan de vratg, en de ITA dus kleiner dan of gelijk is aan 1,00, word het arbeidsmarktperspectief als goed geryperel. Als de walade van de ITA zelfs kleiner dan of gelijk is aan 0,85 dan wordi gesproken van een zeer goed arlseidsmarktperspectief. Wanneer de ITA daarentegen een walarde heeft tussen de 1,00 en 1.05 en het alanbodoverschon niet veel groter is dan watt als frictic kan worden beschourwd, wordt gesproken van een redelijk arbeidsmarktperspectiel. Bij een hogere walarele van cle ITA word het arbeidsmarktperspectief vorr het destretreffende opleidingstype als matig, of als de l"TA zelfs groter is dan 1,15 , als slecbtatangeduid.

lien atanboloverschot impliceert echter niet vanzellsprekend dat de deshetreffende groep werkloos zal worken en een anboltekon betekent niel automatisch dat er sprake al zijn van onvervulde valcallures. Het is immers ook mogelijk dal werkgevers

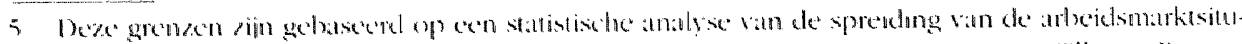

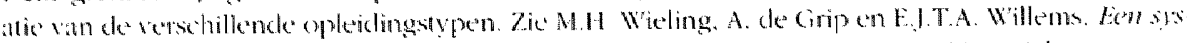

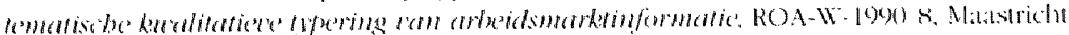


hun eisen aanpassen en mensen aannemen met een andere opleidingsachtergrond dan aanvankelijk gevraagd werd. Schoolverlaters met een opleiding waarvoor het aanbod de vraag overtreft ervaren in een dergelijke situatie een verslechtering van hun positie doordat zij bijvoorbeeld vaker beneden hun niveau of buiten hun vakrichting moeten werken, slechter beloond worden of vaker genoegen moeten nemen met part-time werk, terwijl men liever een full-time betrekking had. Omgekeerd zal bij een tekortschietend aanbod de positie van schoolverlaters verbeteren. Deze hoeven in dat geval minder vaak genoegen te nemen met een functie op een lager niveau, een lagere beloning e.d.

Bij de opleidingen die door opleidingstypen met een aanbodoverschor worden verdrongen, zal het aantal baanopeningen vanwege dit substitutieproces kleiner worden. Daarentegen zal er voor de opleidingen die verwant zijn aan de opleidingen met een tekortschietend aanbod juist sprake zijn van extra baanopeningen. Deze passieve substitutie-effecten zijn derhalve, wanneer er sprake is van knelpunten, van belang voor de arbeidsmarkt-perspectieven van de desbetreffende opleidingen.

De vraag-aanbod-confrontatie geeft voor elk opleidingstype ook een indicatie van de toekomstige knelpunten in de personeelsvoorziening. Daarbij bepalen de uitbreidingsen vervangingsvraag samen de recruteringsbehoefte per opleidingstype. Bij krimpende werkgelegenheid voor een bepaald opleidingstype wordt deze recruteringsbehoefte op een andere wijze berekend dan het aantal baanopeningen voor nieuwkomers op de arbeidsmarkt. In dat geval bestaat immers vanuit het perspectief van bedrijven de mogelijkheid om de gedwongen uitstroom van het zittende personeel te vermincleren. Zeker wanneer bedrijven geconfronteerd worden met een krappe arbeidsmarkt voor een bepaald opleidingstype, mag worden aangenomen dat zij van deze mogelijkheid gebruik zullen maken.

In dit rapport staat het in kaart brengen van de aansluitingsproblematiek tussen onderwijs en arbeidsmarkt verbijzonderd nata de onderscheiden opleidingstypen centratil. In aanvulling daarop wordt inzicht gegeven in de implicaties die de valag-atanbodverloudingen voor de onderscheiden opleidingstypen hebben woor de knelpunten in de personeelswoorziening per beroepsgroep. Inzicht in de knelpunten natar beroepsgrocp is vor verschillende gebruikers en gebruiksdoelen relevant. Voor werkgevers kan inzicht in de knelpunten natar beroepsgroep van belang zijn voor hun wervings- en personeelsbeleid. Op de tweede platsts kunnen (langdurig) werklozen of werkenden dic op zoek zijn naar een andere werkkring gebruik maken van de inlormatice in hun orientatie nald een nieuwe of andere werkkring. Natuw met clit iweede getoruiksckel salmenhangend zijn bij- en omscholingsprogramma's doorgatans geticht op een bepatalde beroepsgroep. Inzicht in de knelpunten naar beroep kan een derhalve leidratat aijn bij het opzetten van dergelijke scholingsprogrammats.

Door de totale verwachte vradg in de prognoseperiode in het betreffende beroxp $10^{\circ}$ rellteren alan enerzijds de wijze waarop werkgevers de valag heogen in le vullen gua

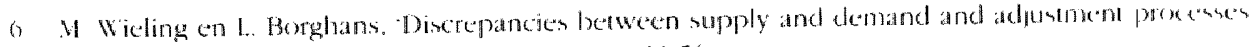

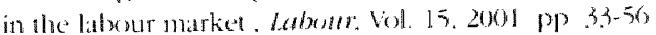


opleidingsachtergrond van de arbeidskrachten en anderzijds de vraag-aanbodverhoudingen voor de voor dat beroep relevante opleidingstypen, wordt een indicatie verkregen van de problemen die werkgevers bij het werven van personeel zullen ondervinden. Wanneer voor een bepaald beroep kennis en vaardigheden vereist zijn die met name alanwezig zijn bij mensen met een bepaalde opleidingsachtergrond waarvoor grote tekorten worden verwacht, zullen werkgevers grote moeite hebben personeel te vinden dat over de in dat beroep vereiste kwalificaties beschikt. Wanneer het hier over zeer beroepsspecifieke expertise gaat, zullen de knelpunten extra groot zijn, aangezien er in dat geval weinig alternatieven voorhanden zijn.

Wanneer het daarentegen meer algemene competenties betreft, kan de werkgever doorgaans mensen met een andere opleidingsachtergrond aantrekken?

In veel gevallen wordt in dit rapport, naast een getalsmatige indicatie, een kwalitatieve typering gegeven van de prognose. Het doel van deze kwalitatieve typeringen is tweeledig. Enerzijds vereenvoudigt de typering de interpretatie van de cijfers. Anderzijds wordt door middel van deze kwalitatieve typeringen rekening gehouden met de onzekerheidsmarges waarmee het opstellen van prognoses gepaard gaat.

De ir alit rapport gehanterede methodick voor het in katrt brengen san de knelpunten in de perso-

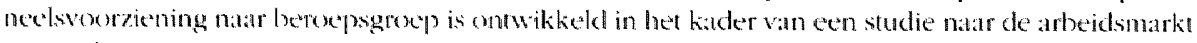

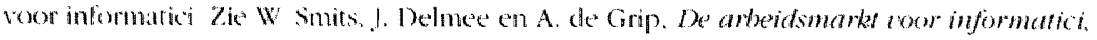

ROA-R-19)8.2. Matastrichth 


\section{De arbeidsmarkt in vogelvlucht}

In dit boofdstuk worden de boofdlinen van de verwachte arbeidsmarktontwikkelingen van 2001 tot 2006 weergegeven. Het boofdsuk begint met cen verantwoording van de macro-economische groeiprognoses en de achteriggende economiscbe en sociale ontwikkelingen, welke een belangrijke invloed bebben op de ontwikkeling van vraag en aanbod op de arbeidsmarkt. Vervolgens worden de verschuivingen in de bedrijfsector: beroepen-en opleidingenstructuur van de werkgelegenheid bekeken. Daarbij zal telkens een vergelijking worden gemaakt met de ontwikkelingen in de afgelopen jaren. Ten slotte wordt een overzicbt gegeven van de verwacbte arbeidsmarktperspectieven voor schoolverlaters op de verscbillende opleidingsniveaus.

\subsection{De verwachte arbeidsmarktontwikkeling}

De in dit rapport gepresenteerde prognoses van de werkgelegenheidsontwikkeling voor de periode 2001-2006 zijn gebaseerd op de korte-termijnprognoses tot en met $2002^{\circ}$ en het 'Global Competition scenario' uil de lange-termijnverkenning tol 2020 van het Centraal Planbureau (CPB)". Dit betekent dat de jaarlijkse werkgelegenheidsgroei in personen naar verwachting afneemt van 1,75\% in 2001 tot ongeveer $1 \%$ in 2006. De gemiddelde jaarlijkse werkgelegenheidsgroei (in personen) in de prognoseperiode bedraagt $1,2 \%$, beduidend lager dan de $2,7 \%$ in de afgelopen periode 1996-2000.

De vertraging tot en met 2002 wordt veroorzaakt door de neergaande conjunctuur. Volgens de Macro Economische Verkenning 2002 van het CPB neemt de groei van het Bruto Binnenlands Product (BBP) af van 3,5\% in 2000 tot $2 \%$ in 2001 en 2002. Hoewel deze groeiciffers beduidend lager zijn dan de eerder dit jaar gepresenteerde prognoses in het Centraal Economisch Plan 2001 (respectievelijk 3\% in 2001 en 2\% in 2002), is de neerwartse aanpassing van de werkgelegenheidsgroei veel minder groot. Deze beperkt zich tot een neerwaartse a anpassing tol $0,75 \%$ in 2002 in plats van $1.25 \%$, $10 \%$ wijl de prognose voor de werkgelegenheidsgroei in 2001 op $1.75 \%$ gehandhafd is. Deze neerwartse aanpassing van de werkgelegenheidsgroei op de korte lermijn heefi derhalve weinig invloed op de in dit rapport veronderstelde werkgelegenheidsgroci op de middellange termijn.

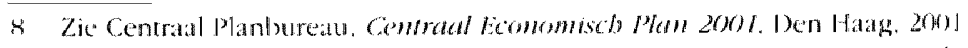

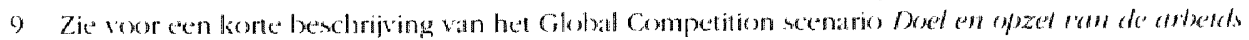
maktprognoses aan hel begin van dit rappon 
Voor de middellange termijn wordt in dit rapport uitgegaan van, zoals hierboven opgemerkt, het Global Competition scenario. In dit scenario spelen technologische ontwikkelingen en internationalisering een belangrijke rol voor de werkgelegenheidsgroei. Van de drie scenario's uit de lange-termijnverkenning van het CPB, sluit het Global Competition scenario het beste aan bij de feitelijke economische en werkgelegenheidsontwikkeling vanaf 1995 tot $2001^{10}$. In dit scenario wordt uitgegaan van een gemiddelde BBP-groei van $3 \%$ per jaar, terwijl er een gemiddelde jaarlijkse werkgelegenheidsgroei (in arbeidsjaren) van 1,1\% wordt voorzien. Dit laatste komt goed overeen met een middellange-termijnraming door het $\mathrm{CPB}$ van de macro-economische groei van de werkgelegenheid in de periode 2002-2006". Deze raming van het CPB gaat uit van de potentiële groei van de economie zonder overbelasting of onderbenutting van de productiecapaciteit, waardoor conjuncturele fluctuaties geen rol spelen.

Hoe groot de exacte negatieve gevolgen van de afvlakkende wereldconjunctuur in combinatie met de terroristische aanslagen in de Verenigde Staten zullen zijn voor de Nederlandse economie en arbeidsmarkt, is op dit moment moeilijk te voorzien. Uit de hierboven genoemde ramingen van het CPB wordt in elk geval duidelijk dat de werkgelegenheidsgroei voor de komende periode beduidend lager zal zijn dan tussen 1996 en 2000. In tabel 1.1 wordt de voor de komende jaren verwachte werkgelegenheidsgroei in personen van $1,2 \%$ gemiddeld per jaar (ten opzichte van het basisjaar 2000) afgezet tegen de gerealiseerde werkgelegenheidstoename in de periode 1996-2000. In totaal gaat het over de periode 2001-2006 om een toename in de werkgelegenheid van ongeveer 85.000 personen gemiddeld per jaar.

Tabel 1.1

Arbeidsmarktontwikkeling 1996-2000 en de prognoses voor de periode 2001-2006, gemiddelde jaarlijkse percentages

1996-2000

$\%$

2.7

Werkgelegenlleidstoename

Arbeidsmarkitulstroom

Bamomeningen

Instonon schoolvertates
3,8

6.5

4.9
2001-2006

$\%$

1,2

4.1

5.3

4,4

Bron: ROACPN)

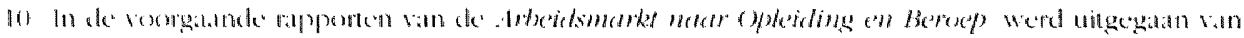

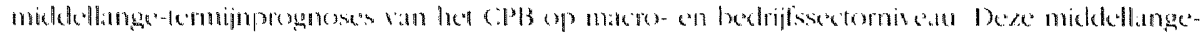

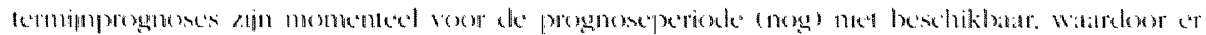

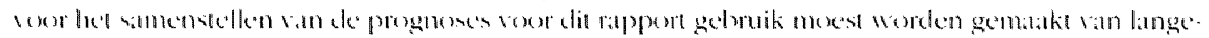

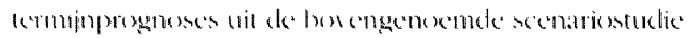

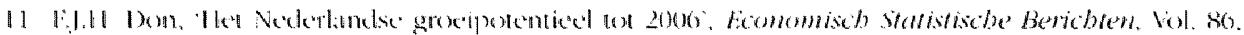

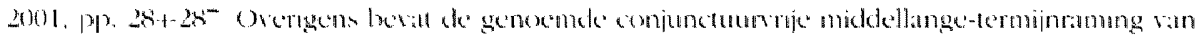

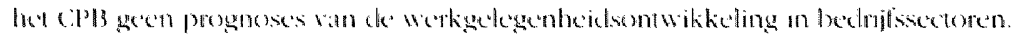


Voor een beoordeling van de spanning op de arbeidsmarkt op macro-niveau zijn tevens de verwachte uitstroom van werkenden en de verwachte instroom van schoolverlaters op de arbeidsmarkt van belang ${ }^{12}$. Tabel 1.1 laat zien dat de uitstroom van werkenden over de periode 2001-2006 ten opzichte van de afgelopen periode naar verwachting slechts licht zal toenemen van 3,8\% naar $4,1 \%$, Hieruit blijkt dat het vertrek van werkenden van de arbeidsmarkt op ongeveer hetzelfde niveau blift. Werkgevers hebben er door de grote krapte op de arbeidsmarkt belang bij de uitstroom ondanks de verdergaande vergrijzing te beperken, en lijken daarin ten dele te slagen. Over de prognoseperiode komen gemiddeld per jaar ongeveer 325.000 banen vrij door de uitstroom van werkenden

Een deel van de banen die door de uitstroom van werkenden vrijkomen wordt echter niet opgevuld. Op sommige segmenten van de arbeidsmarkt valt het vertrek van werkenden samen met bijvoorbeeld bedrijfssaneringen en reorganisaties. De in beginsel vrijkomende arbeidsplaatsen bij het vertrek van personeel (bijvoorbeeld bij natuurlijke afvloeiing) worden daardoor niet opnieuw bezet. De hiermee gepaard gaande krimp van de werkgelegenheid bedraagt in de prognoseperiode naar verwachting ongeveer 55.000 personen gemiddeld per jaar ${ }^{13}$. De resterende uitstroom van ca. 275.000 personen gemiddeld per jaar zal moeten worden opgevuld door nieuwkomers. Een deel van deze vervangingsvraag ontstaat overigens cloordat personen van opleidingsachtergrond veranderen door het volgen van een niveauverhogende of richtingveranderende additionele opleiding naast hun werk ${ }^{13}$. Hierdoor ontstaan arbeidsplaatsen voor anderen met de "oude' opleidingsachtergrond. Het gaat hierbij naar schatting om 85.000 arbeidsplaatsen per jaar.

De sterke daling van de werkgelegenheidstoename zorgt er voor dat per salclo het aantal baanopeningen aanzienlijk zal dalen, van $6,5 \%$ gemiddeld per jaar in de afgelopen periode naar $5,3 \%$ in de prognoseperiode. De daling van de vraag naar arbeid op macro-niveau leidt echter niet tot een evenredige vermindering van de spanning op de arbeidsmarkt, omdat ook het aanbod van schoolverlaters verder daalt. De instroom van deze nieuwkomers op de arbeidsmarkt daalt vanwege de 'ontgroening' van de beroepsbevolking van $4.9 \%$ tot $4,4 \%$. Het aantal schoolverlaters dalt op de arbeidsmarkt instroomt zal over de prognoseperiode jaarlijks gemiddeld ongeveer 425.000 zijn, wilaronder de eerder genoemde 85.000 werkenden die een additionele opleiding heblon afgerond. Aangezien de daling van het aantal baanopeningen groter is dan de daling van de arbeidsmarktinstroom van schoolverlaters, lijkt de spanning op de arlocidsmarki in de periode 2001-2006 iets af te nemen ten opzichte van de periode 1996-20000. Uiterard zegt deze afnemende spanning op macro-niveau nog weinig over de vratagen aanbodverhoudingen op het niveau van specifieke opleidingen en beroepen

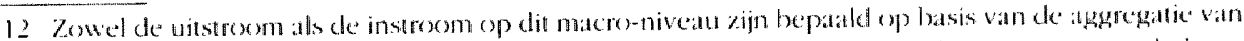

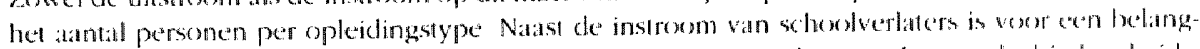

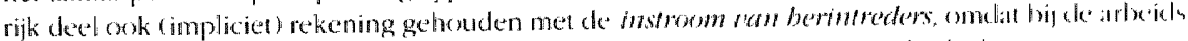

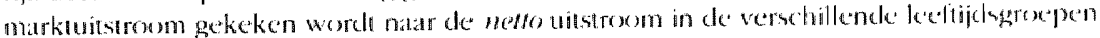

1.3 Met deze werkgekegenheidskrimp is al rekening gehouden bij het bepaten van de (ne'llon werkgelegenhedatoename

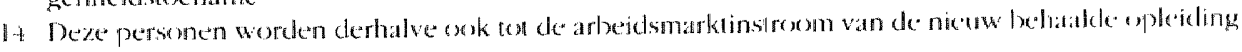
gerekend. 
Een andere belangrijke kanttekening die gemaakt kan worden is dat er aan het begin van de periode 1996-2000 nog een hoge werkloosheid heerste en een 'stille reserve" bestond waarvan een alanzienlijk aantal personen beschikbaar voor de arbeidsmarkt was. Dit arbeidsreservoir is anno 2001 dusdanig geslonken dat hieruit voor veel segmenten van de arbeidsmarkt nauwelijks nog geput kan worden. Voor werkgevers betekent dit dat het verlengen van het werkzame arbeidsleven van oudere werknemers en het voorkomen dat vrouwen zich terugtrekken van de arbeidsmarkt voor de zorg van hun kinderen en huishouden, nog belangrijker zullen worden dan voorheen om de knelpunten in de personeelsvoorziening te verlichten ${ }^{15}$.

\subsection{Werkgelegenheidsontwikkeling naar bedrijfssector}

De sectorale ontwikkelingen in de werkgelegenheid wijzen tot op heden op een voortschrijdende 'tertiairisering' van de economie, waarbij zowel de zakelijke dienstverlening als de kwartaire sector een rol spelen. In tabel 1.2 wordt dit uitgedrukt door de hoge gemiddelde jaarlijkse groeicijfers in de periode 1996-2000 van het bank-en verzekeringswezen, de boreca en zakelijke dienstverlening, en de kwartaire diensten. Verder heeft ook de conjuncturgevoelige sector bouw en onroerend goed de afgelopen jaren een opmerkelijk hoge groei laten zien.

Tabel 1.2

Ontwikkeling van het aantal werkenden per bedrilfssector 1996-2000 en de uitbreidingsvraag naar bedrijfssector 2001-2006, gemiddelde jaarlijkse percentages

Bedrijfssector

Landbouw en visserij

Vooding

Chente

Metaral en elektrotechntek

overlge indenstrite

Finesgite

Bouw en onroerend goed.

Handel en repantic

Transport en commounicatus

Bunk- en verezekertingswezten

Horeca en zakelijke dienstverlening

Kw:urtaire diensten

Overheid en onderwijs

'Total (ind, sector onbekend)
Aantal werkenden

gem. 1999-2000

$$
\begin{array}{r}
211.000 \\
160.000 \\
125.000 \\
526.000 \\
215.000 \\
53.500 \\
517.500 \\
919.500 \\
425.000 \\
275.500 \\
1.103 .000 \\
1.133 .500 \\
967.000 \\
6.861000
\end{array}
$$

1996-2000

$\%$

$-1,5$

0,4

$-1,1$

0,8

0,6

$-3.9$

3,9

2.3

3,0

6,1

6,5

3.7

1.4

2.7
2001-2006

\section{$\%$}

$-2,1$

0,8

0,8

$-0,2$

$-0,9$

0,3

1.7

1.6

1,0

$-0,4$

2,7

1,3

1,1

1,2

Bron: ROA(POA) / CPBB(Global Competition, (WB) / CBS(BBBB)

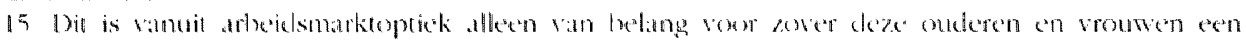

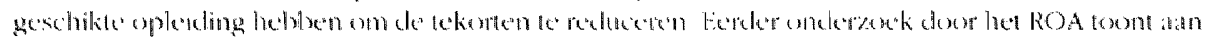

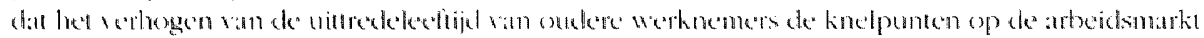

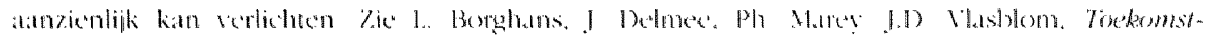

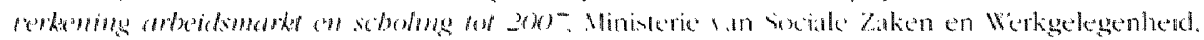
ben Haig, lous 
Tabel 1.2 geeft tevens een overzicht van de verwachte werkgelegenheidsontwikkeling in de diverse bedrijfssectoren over de middellange termijn ${ }^{16}$. De vertraging van de groei van de werkgelegenheid van $2,7 \%$ in de periode $1996-2000$ tot $1,2 \%$ in de periode 2001 2006 treft de meeste sectoren. In het door snelle technologische ontwikkelingen en verdergaande internationalisering gekenmerkte Global Competition scenario (zie paragraf 1.1) wordt echter een gunstige ontwikkeling voorzien voor de hoog- en middelwaardige delen van de voedingsmiddelenindustrie en de chemische industrie. Dit vertaalt zich in een hogere groei voor de voedingssector, en een omslag in de werkgelegenheidsontwikkeling van krimp naar groei voor de chemische industrie.

In tegenstelling tot de industriële sectoren, is er in de dienstsectoren in het algemeen minder ruimte voor verbetering van de arbeidsproductiviteit. De economische groei in deze sectoren, met name met betrekking tot de traditionele diensten, vertalt zich clatrdoor doorgaans meer in werkgelegenheidsgroei dan bij de industriële sectoren. Voor de ICT-diensten geldt echter dat de productiviteitsstijgingen aanzienlijk kunnen zijn, en kan de werkgelegenheidsgroei in belangrijke mate gerelateerd worden aan de toename van de consumptieve bestedingen aan deze diensten ". De sectoren die hel grootste deel van de werkgelegenheidsgroei voor hun rekening nemen, zijn clan ook de dienstensectoren bandel en reparatie, boreca en zakelijke dienstverlening, en kuartair" diensten. De groei van de kuartaire diensten, waaronder de gezondheidszorg, ligt nata verwachting op een lager niveau dan in de voorgaande periode, maar is nog sleeds iets hoger dan gemiddeld. De boreca en zakelijke dienstverkning blift qua werkgelegenheid de snelst groeiende sector, hoewel de hoge groeiciflers van de tweede helft van de jaren negentig meer dan gehalveerd worden. Hetzelfde geldt overigens ook voor de bouwsector, waarvoor ondanks de verwachte teruglopende conjunctuur een bovengemiddelde werkgelegenheidsgroei wordt verwacht.

Voor de andere sectoren in tabel 1.2 geldt dat de werkgelegenheid in de landboutu en visserij onveranderd blijft krimpen. De werkgelegenheid in de metaal en elektrotechniek en de overige industrie zal eveneens afnemen, na een solide groei in de tweede helf van de jaren negentig. In de energie-sector zal de werkgetegenheid zich enigszins herstellen. In deze sector lijkt de periode van rationalisaties voorlopig voorbij. De werkgelegenheidsgroei in de handel en reparatie en cle transport en communicatio daalt, hoewel de verwachte werkgelegenheidsgroei voot de handel en reparatic hoget dan het gemiddelde ligl voor de komende periode. De krachtige groeispurt valn hel bomk-en verzekeringstezen in de algelopen jaren, neemt snel al en zal na 2002 zellis omslatan in een krimpencle werkgelegenheid de werkgelegenheid in de sector onerbeid en onderwijs zal daarentegen blijven groeien, matr valt voor de komende jaren wel terug tot iets onder hel gemiddelde'

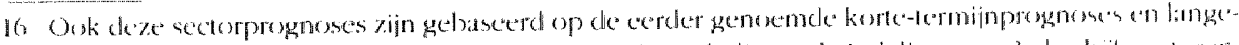

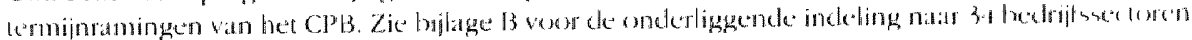
De sectorprognoses zijn echer alleen beschikbat voor do konte seeforindeling

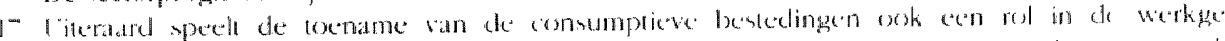

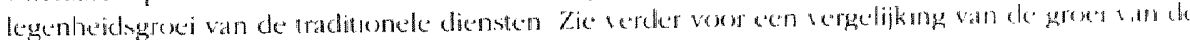

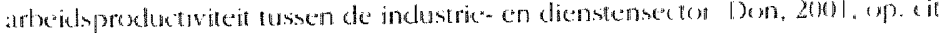

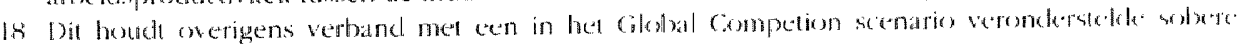
dienswerlening van de overheic 


\subsection{Werkgelegenheidsontwikkeling naar beroepsklasse}

Door zowwel veranderingen van de werkgelegenheid in de verschillende bedrifssectoren als vernieuwingen in de productietechnieken en de organisatie, treden er verschuivingen op in de beroepenstructuur van de werkgelegenheid. De eerstgenoemde veranderingen zijn meer intersectoraal van aard, en worden onder andere bepaald door de ontwikkelingen in het bestedingsgedrag van consumenten en de beschikbaarheid van productiefactoren. De veranderingen in de productietechnieken en de organisatievormen zijn daarentegen meer intrasectoraal van aard, en hangen samen met het innovatie- en concurrentievermogen van bedrijven in deze sectoren.

Tabel 1.3 geeft een overzicht van de gerealiseerde en de verwachte werkgelegenheidsontwikkeling per beroepsklasse voor respectievelijk de periodes 1996-2000 en 20012006. De gevolgen van de tertiairisering komen duidelijk naar voren: de werkgelegenheidsontwikkeling blift relatief hoog voor de (sociaal)-culturele beroepen, informaticaberoepen en economiscb-administratieve beroepen. De werkgelegenheid blift zich, ondanks de beduidend lagere groeiciffers, in de richting van deze beroepen ontwikkelen. Hiermee wordt de trend van de afgelopen jaren doorgezet, zij het met aanmerkelijk minder spectaculaire groeicijfers voor informatici, economen en werkenden met een sociaal-culturele achtergrond dan in de periode 1996-2000.

Tabel 1.3

Ontwikkellng van het aantal werkenden per beroepsklasse 1996-2000 en de uitbreidingsvraag naar beroepsklasse 2001-2006, gemiddelde jaarlijkse percentages

\section{Beroepsklasse}

Pedagogische beroepen

Cullurele beroepen

Agrarische beroepen

Tuchubche en Undustrieheropen

Transportherowen.

Medische en paramedische beroepen

Fonomisch-administratieve beroepen

Informaticaberopen

Siociatil-cullurele beroepen

Ver/argende en diensiverlenende beroepen

Openbrate orde en veiligheidsberopen

Totail (ind. beroep onbekend)

Bron: $\mathrm{KOA}(\mathrm{PO}) \mathrm{A}) / \mathrm{CBS}(\mathrm{B}: \mathrm{BB})$
Aantal werkenden

gem. 1999-2000

355.000

139.000

262.000

]. 483.000

392.000

394.500

1.987 .000

248.500

215.500

1.095 .000

103.500

$\$ 861.000$
1996-2000

$\%$

2001-2006

$\%$

0,7

1,5

$-11,5$

0,0

0,6

0.8

2,1

2.8

3.2

0,6

0.7

1,2

Voor cle mediscbe en parmedische beroepen was dit tot 2001 ook hel geval, mat zal natr verwachting de groei op middellange termijn achterblijven bij de gemiddelde grox. De transportberoepen, de werzorgende en diensterlenende beroepen en de open-

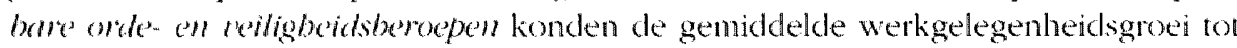
2001 nog goed volgen. matr laten natr verwachting in de periode $2001-2006$ een lager dan gemicklelde groej zien. 
De beroepenstructuur ontwikkelt zich verder ongunstig voor de beroepen in de agrarische en industriële sectoren. Er zal naar verwachting een versnelling van de krimp van de werkgelegenheid in de agrariscbe beroepen optreden, en een stagnatie van de groei in de technische en industrieberoepen. Deze stagnatie van de groei van de techniscbe en industrieberoepen wijst erop dat voor deze beroepen de dalende werkgelegenheid in een aantal sectoren van de industrie, niet opweegt tegen de werkgelegenheidsgroei in de bouwnijverheid en het verwachte herstel van de werkgelegenheidsgroei in de voedingssector en de chemische industrie. De werkgelegenheidsgroei in de pedagogiscbe beroepen daalt licht en blijft lager dan gemiddeld.

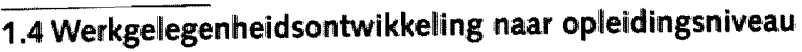

De veranderingen in de uitbreidingsvraag naar opleiding worden niet alleen bepaald door de verschuivingen in het groeitempo van de diverse bedrijfssectoren en beroepsklassen, maar ook door de verschuivingen in de gevraagde kwalificaties binnen beroepen. Toenemende internationalisering, voortschrijdende technologische ontwikkelingen en de daaraan gerelateerde organisatorische veranderingen kunnen belangrijke oorzaken zijn van de toegenomen kwalificatie-vereisten. De technologische ontwikkelingen leiden tot een toenemende complexiteit van veel functies ${ }^{10}$. Daarnaast bewerkstelligen de technologische ontwikkelingen vaak ook organisatorische veranderingen, zoals het schrappen van managementlagen, decentralisering, 'empowerment', en dergelijke, die op hun beurt de kwalificatie-eisen verder doen stijgen ". Fen belangrijke rol speelt daarbij dat massaproductie in alle sectoren plaats maakt voor op cle consument afgestemd maatwerk en een toenemend belang van de kwaliteit van de geleverde goederen en diensten. Het laatste komt tot uiting in de toegenomen aandacht voor kwaliteits-zorg. Zowel bij de meer op proceskwaliteit gerichte kwaliteitszorg (ISOnormering) als bij de meer op het product gerichte kwaliteitszorg (bijvoorbeeld Total Quality Management) is doorgaans meer aandacht voor het belang van goed geschoold personeel ${ }^{n}$. Hierbij gaat het zowel om het eigen personeel als het personeel van de toeleveranciers.

In tabel 1.4 word een overzicht gegeven van de gerealiseerde werkgelegenheidsgroci en de verwachte uitbreidingsvatag nat opleidingsniveau. De gevolgen van cle: upgratding van de gevraagde kwalificaties zijn wat betrefi de gerealiseerde werkgelegenheidsgroei voor de periode $1996-2000 \mathrm{nog}$ niet eencluidig zichubar. De label latal wel zien dat de verwachte gemiddelde jarlijkse groei van de uitbreidingsvrata in het algemeen groter is bij een hoger opleidingsniveau. Er word een alname verwatht van de vraag natr arbeidskrachten mel basisonderwijs en VMBO. terwijl de vraig nata arbeidskrathten met HAVO VWO, MBO, HBO en WO stijgt. Overigens is alleen voor arbeidskrachten met $M B O$ de toename van de vraag groter dan de werkgelegenheidsgroei in cle vooralgatande periode.

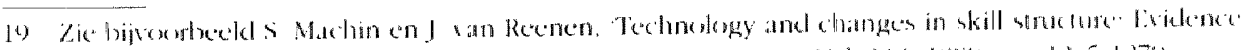

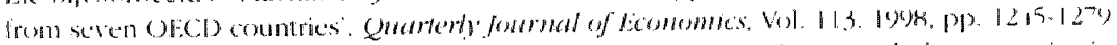

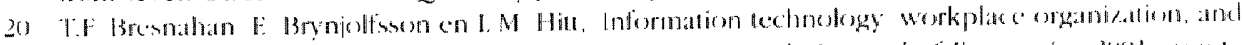

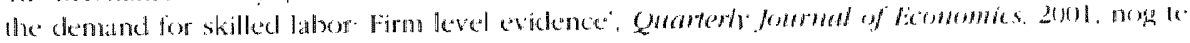
versehimen.

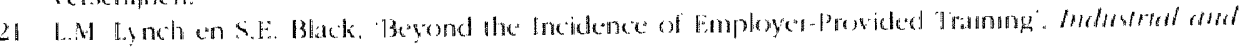

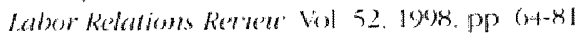


In de periode 1996-2000 hebben schoolverlaters, werklozen en andere niet-werkenden met basisonderwijs als hoogst woltooide opleiding sterk geprofiteerd van de hoge werkgelegenheidsgroei. Aangenomen mag worden dat dit voor een belangrijk deel het gevolg is van de schaarste aan beter opgeleiden, waardoor werkgevers weinig andere opties hadden dan het aantrekken van ongeschoolden ${ }^{22}$. De vraag naar mensen met alleen basisonderwijs zal echter in de komende periode 2001-2006 naar verwachting sterk afnemen. Door terugval van de algehele groei wordt derhalve een daling van de werkgelegenheid verwacht voor de werkenden die nagenoeg als ongeschoold kunnen worden beschouwd. Na een periode van lichte werkgelegenheidsgroei neemt mede als gevolg van de upgrading van de gevraagde kwalificaties, naar verwachting ook de vraag naar arbeidskrachten op VMBO-niveau af.

Tabel 1.4

Ontwikkeling van het aantal werkenden per opleidingsniveau 1996-2000 en de uitbreidingsvraag naar opleldingsniveau 2001-2006, gemiddelde jaarlijkse percentages

\section{Opleidingsniveau}

Basisonderwijs

VMBO

HANONWO

MBO

$\mathrm{HBO}$

WO

Total (incl. opleiding onbekend)
Aantal werkenden

gem. 1999-2000

548.000

1.292 .000

387.000

2.508 .500

1.241 .000

569.000

6.861 .000
1996-2000

\section{$\%$}

3,5

0,2

5,8

1,3

3,4

6,1

2,7
2001-2006

$\%$

$-5,2$

$-1,3$

3,0

1,8

2,8

3.7

1,2

Bron: $\mathrm{ROA}(\mathrm{POA}) / \mathrm{CBS}$ (BBB)

Naast de upgrading van de gevraagde kwalificaties spelen ook andere factoren een rol bij de verschuivingen in de werkgelegenheid naar opleidingsniveau. Tabel 1.5 geeft een overzicht van de verschillende componenten van de verwachte werkgelegenheidsontwikkeling natal opleidingsniveau ${ }^{23}$. Hierbij wordt onderscheid gemaakt tussen:

- verschillen in de werkgelegenheidsontwikkeling van bedrijfsectoren: het bedrijfssectoreffect;

- verschuivingen in de beroepenstructuur binnen bedrifssectoren: het berospseffect:

- veranderingen in de gevralagde opleidingsachtergronden binnen beroepen: hel opleidingseffect. Dil effect geefl de mate van upgrading binnen beroepen weer:

- adklitionele vratg (in positieve of negatieve zin) door a anbodtekorten of a anbodoverschotten bij vanuit arheidsmarktoogpunt verwante opleidingen: het passieve swbstitutioweffect. Dit effect geeft de verdringing van opleidingen weer door opletdingen van een hoger nivealu met aanbodoverschotten of omgekeerd de ambuigendke working clic uitgata van een tekortschietend aanbod op mensen met exen verwante opleidingsichtergrond.

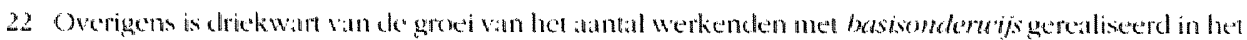
lanste jaat van de pertude $1096-2000$

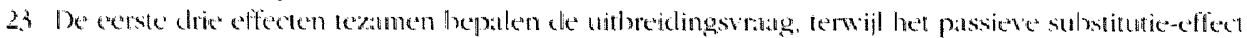

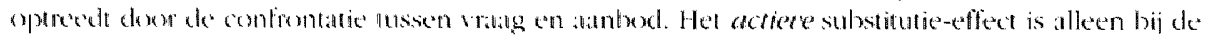
Feitelijke wetkgelegenheidsontwikleling inhegrepen. 1 ex post). Zie ook de witleg in de begrippen-

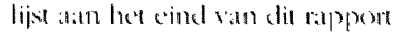


Uit de tabel blijkt dat de verschillen in de werkgelegenheidsgroei ussen bedriffssectoren effect hebben op de verschuivingen in de samenstelling van de werkgelegenheid naar opleidingsniveau. Er is sprake van een lichte toename van dit effect met het opleidingsniveau, van basisonderwijs met $5,7 \%$ tot WO met $6,9 \%$. Dit wijst erop dat de kennisintensieve sectoren, waarbij kennisintensiteit wordt benaderd door de werkgelegenheidssamenstelling naar opleidingsniveau, gemiddeld genomen harder groeien dan de minder kennisintensieve sectoren. De veranderingen in de intersectorale samenstelling van de werkgelegenheid duiden erop dat we ons bewegen in de richting van een kenniseconomie.

label 1.5

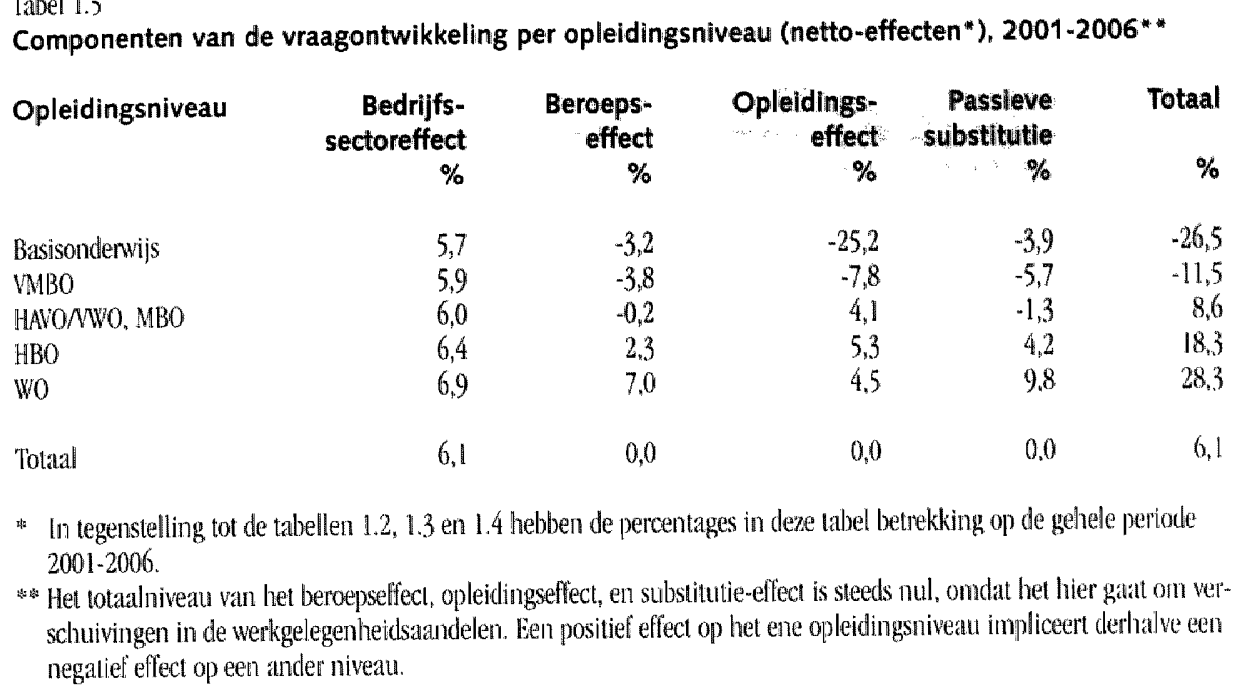

Bron: $\mathrm{ROA}(\mathrm{POA})$

Pas bij het beroepseffect zijn er echter a anzienlijke verschillen tussen opleiclingsniveatus watr te nemen. Door intrasectorale verschuivingen van de beroepenstructure necml cle vraag naar werkenden met een opleidingsniveau tot en met het midelelbare niveall al. terwijl de vraag nar hoger opgeteiden (HBO en WO) toeneemt. Deze berocpseffecten worden nog eens versterkt door veranderingen in de gevraigde opleidingsacthtergersnden binnen beroepen: met name voor het basisonderwijs is er een sterk negall iel opleidingseffect van mar liefst $-25.2 \%$, terwij ook voor het $\mathrm{VMBO}$ een grool negalliel opleidingseffect van $-7,8 \%$ word verwadht. Vero hoger opgeleiden worden de ponsilieve: beroepseffecten versterkt door positieve opleiclingselfecten. watardoor de werkgelegenleid in de periode 2001-2000 voor HBO toeneemt met 5,3\% en W/ med 4, $4 \%$. Fien uizondering op hee patroon vormt het midellare niveatu hier compenseert een posi-

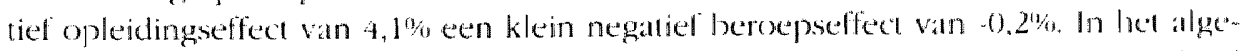
meen wijst ook de groei van de intrasectorale samenstelling van de werkgelegentreid op de ontwikkeling in de richting van een kenniseconomice. De verwachte werkgetegenheidsgroei van beroepen is hoger natrmale het geniddelde opleidingsniveatl van die beroepen hoger is, terwijl bovendien he gemidelede opleidlingsniveallu binnen de. beroexpen stijgt. 
Ten slotte worden de inter- en intrasectorale werkgelegenheidsverschuivingen versterkt door de substitutievraag. Uit de tabel blijkt dat het substitutie-effect voor de periode 2001-2006 op alle opleidingsniveaus in dezelfde richting werkt als het beroepseffect en het opleidingseffect, met uitzondering van het opleidingseffect voor het HAVO/VWO en $M B O$. Met name voor hoger opgeleiden van het $W O$ is het substitutie-effect erg groot. Dit substitutie-effect is het gevolg van de grote aanbodtekorten voor veel opleidingstypen binnen het hoger onderwijs. Hierdoor ontstaat er extra substitutievraag naar verwante opleidingsrichtingen van het hoger onderwijs. Er ontstaat dan als het ware een soort olievlekwerking, waardoor de knelpunten op de arbeidsmarkt zich verspreiden over vrijwel allle opleidingstypen in het hoger onderwijs.

\subsection{Toekomstige arbeidsmarktperspectieven naar opleidingsniveau}

Indien de verwachte baanopeningen per opleidingstype en de verwachte additionele substitutievraag worden geconfronteerd met de instroom van schoolverlaters en de potentiële instroom van kortdurig werklozen, kan een indicatie worden gegeven van de toekomstige arbeidsmarktperspectieven per opleidingstype. Zoals in de vorige paragraaf werd aangegeven is dit in belangrijke mate het gevolg van de verwachte upgrading van cle kwalificatie-eisen en de anzuigende werking die uitgaat van de knelpunten op de arbeidsmarkt bij verwante opleidingen. Tabel 1.6 geeft een overzicht van de verwachte vraag-aanbod stromen en het daaruit resulterende arbeidsmarktperspectief voor schoolverlaters op basis van de Indicator Toekomstig Arbeidsmarktperspectief (ITA). In de tabel zijn de resultaten voor de 104 onderliggende opleidingstypen geaggregeerdi tol de vijf opleidingsniveaus. De ITA geeft de ex ante spanning tussen vraag en aanbod van schoolverlaters aan op basis van de verwachte ontwikkelingen van de uitbreidingsvraag, de vervangingsvraag en de instroom. Een ITA groter dan 1,00 duidt op een ex ante alanbodoverschor en dus een minder gunstig arbeidsmarktperspectief. Naarmate de ITA daalt wordt het perspectief beter.

De arbejclsmarktperspectieven voor schoolverlaters verbeteren met het opleidingsniveatu, althans vanaf het VMBO-niveau: het perspectief voor schoolverlaters met basisonderwijs is beter dan het perspectief voor schoolverlaters van het $V M B O$. Dit relatief nog gunsige arbeidsmarkiperspectiel voor schoolverlaters met basisonderwijs als hoogst voltooble opleiding is opmerkelijk. Deze schoolverlaters zijn voor een belangrijk deel 'drop-outs' van het $V M B O O^{3}$. Hierbij word er overigens vanuit gegaan dall de schoolverlaters op de atreidsmarkt weinig concurrentie ondervinden van de werkendlen met alleen basisondentijs die de komende jaren hun baan zullen verlie$x^{*} n^{* 3}$. De schoolverlaters met alleen basisonderwijs clanken hun redelijke arbeidsmarktpositic atan lat feit dat veel drop-outs er later in hun arbeidsleven voot kiezen om aan eon vervolgopleiding in thet post-initiële onderwijs deel te nemen. Als zij voor een dergelijke opleiding sligen, ontstat er vervangingsvraig natr personen met basisonderwijs. Dil komt to witing in de erg hoge vervangingsiratg voor mensen met alleen

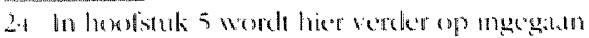

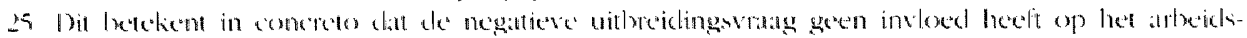

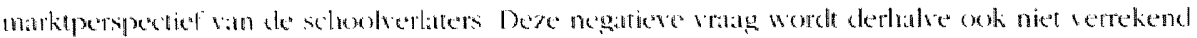

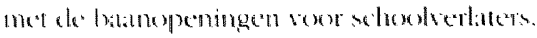


basisonderwijs, die het ontbreken van uitbreidingsvraag, de negatieve substitutievmang en de relatief hoge arbeidsmarktinstroom compenseert. Een dergelijke compensatie is er niet voor schoolverlaters van het $V M B O$, waardoor hun arbeidsmarktperspectief matig is. Ook voor schoolverlaters van het HAVO/VWO zijn de perspectieven matig, ondanks de relatief hoge uitbreidings- en vervangingsvraag. De matige perspectieven zijn vooral een gevolg van de hoge arbeidsmarktinstroom. Evenals bij de arbeidsmarktinstroom van schoolverlaters van het basisonderuijs zijn er relatief veel drop-outs uit het reguliere onderwijs die met HAVONVWO als hoogst voltooide vooropleiding op de arbeidsmarkt instromen. Daarnaast bevinden zich onder de arbeidsmarktinstroom relattief veel werkenden die een post-initiële opleiding op HAVO/VWO-niveau hebben behatid ${ }^{20}$.

Tabel 1.6

Uitbreidingsvraag, vervangingsvraag en arbeidsmarktinstroom (gemiddelde jaarlijkse percentages) en de daaruit volgende toekomstige arbeidmarktperspectieven per opleidingsniveau, 2001-2006

$\begin{array}{lrrrrrr}\text { Opleidingsniveau } & \begin{array}{r}\text { Uitbreidings- } \\ \text { vraag } \\ \%\end{array} & \begin{array}{r}\text { Vervangings- } \\ \text { vraag } \\ \%\end{array} & \begin{array}{r}\text { Substitutle- } \\ \text { vraag } \\ \%\end{array} & \text { Instroom } & \text { ITA } & \text { Typering } \\ & & & & & & \\ \text { Basisonderwijs } & -5,2 & 5,9 & -0,8 & 4,7 & 1,01 & \text { redelijk } \\ \text { MBO } & -1,2 & 3,8 & -1,2 & 4,3 & 1,10 & \text { matig } \\ \text { HAVONW0 } & 3,0 & 4,6 & 0,0 & 8,9 & 1,11 & \text { matigg } \\ \text { MBO } & 1,8 & 3,5 & -0,4 & 4,1 & 0,98 & \text { goed } \\ \text { HBO } & 2,8 & 3,2 & 0,8 & 4,0 & 0,90 & \text { goed } \\ \text { WO } & 3,6 & 2,4 & 1,9 & 3,9 & 0,85 & \text { zeer goed }\end{array}$

Bron: ROA(POA)

Voor de schoolverlaters van het $M B O$ en $H B O$ gelden er goede toekomstperspectieven ${ }^{2-}$, terwijl voor schoolverlaters van het WO zelfs zeer goede perspectieven worden verwadh. Deze gunstige arbeidsmarktperspectieven zijn toe te schrijven alan de hoge uithreidingsvraag en substitutievralag. 1)e vervangingsvraag en de instrom nemen dataentegen juist af met cle stijging van bet opleidingsnive"atu. De fetaticl hoge uitloreiclingsen substitutievraag voor $H B O$ en WO compenseren ochter ruimschoots de achlerblijvende vervangingsvratg. Opvallend is dat de verwachte instrom van personen mel een HBO- of WO-opleiding op de arbeidsmatat als percentage van het aantal wertikenden met een hogere opleiding, achterblift bij de gemiddekde arbeidsmarktinstgom. Ook dit is een oorzak van de goede tor zeer goede arbeidsmarkaperspectieven von HBO'ers en WOers.

Bij het bovenstaande moet in aammerking worden genomen, dat de petspectieven kunnen verschillen tussen de diverse opleidingstypen binnen de vifi onderscheiclen opleidingsnivearts. Tabel 17 geeft aan hoeveel procent van de scheolvertatersop olk oplei-

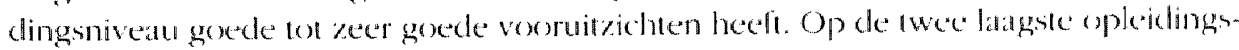

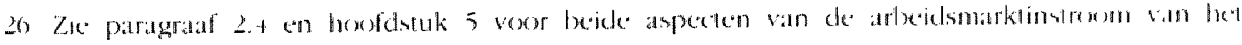
HAIOHO

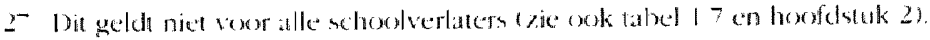


niveaus en het HAVO/VWO heeft bijna geen enkele schoolverlater dergelijke goede vooruitzichten. Op het opleidingsniveau $M B O$ heeft daarentegen $56 \%$ van de schoolverlaters goede tot zeer goede perspectieven op de arbeidsmarkt. Dit betekent dat voor een belangrijk deel van de schoolverlaters van de verschillende opleidingen van het $M B O$ minder goede of zelfs slechte perspectieven worden verwacht (zie hoofdstuk 2). Van de schoolverlaters van het $H B O$ en WO kan het overgrote deel rekenen op goede toekomstperspectieven.

Tabel 1.7

Percentage schoolverlaters waarvoor een goed tot zeer goed arbeidsmarktperspectief wordt verwacht per opleidingsniveau, 2001-2006

\section{Opleidingsniveau}

MBO

$\mathrm{HBO}$

'lotaal

Bron: ROA(PON)

De keerzijde van de goede arbeidsmarktperspectieven voor schoolverlaters wordt door de werkgevers ondervonden in de vorm van knelpunten in de personeelsvoorziening. Zij zullen deze ervaren voor hoger opgeleiden en een belangrijk deel van de opgeleiden met een middelbare beroepsopleiding. Nalar verwachting zullen voor de lager opgeleiden, vanwege de krimpende werkgelegenheid op cle laagste twee opleidingsniveaus, doorgalans geen knelpunten worden ondervonden. 


\section{Ontwikkelingen op de arbeidsmarkt, 2001-2006}

In dit boofdstuk komen de meest opmerkelijke arbeidsmarktontwikkelingen zoals dit worden verwacbt voor de periode 2001-2006 aan de orde, verbijzonderd naar beroep en opleiding. Bij de bespreking van de vraag-en aanbodzijde van de arbeidsmarkt in dit boofdstuk worden 11 beroepsklassen en 17 opleidingscategorieën onderscheiden. Daarbij worden de meest opmerkelijke ontwikkelingen van de onderliggende beroepsgroepen respectievelijk opleidingstypen genoend". Eerst worden de ontwikkelingen aan de vraagzijde van de arbeidsmarkt in de paragrafen 2.1 en 2.2 nader belicht. Hierbij wordt in paragraaf 2.1 ingegaan op de witbreidingstraag voor de onderscheiden beroepsklassen en opleidingscategorieën. Daama wordt in paragraal 2.2 ingegaan op de vervangingsurag voor deze beroepsklassen en opleidingscategorieên. Vervolgens wordt in paragraaf 2.3 een beeld gescbetst van de verwachte baanopeningen. Bij een toename van de werkgelegenbeid vormen vervangingstraag en witbridingstraag tezamen bet aantal baanopeningen voor nienukomess op de arbeidsmarkt Als er sprake is van een negatieve uitbreidingsvraag zijn er echter alleen baanopeningen als gevolg van vervangingsuraag. Tegenover de traag naar mienue arbeidskrachten staat bet verwachte aanbod op de arbeidsmarkt. Een belangrijk deel van bet loskomstige aanbod op de arbeidsmarkt wordt gevormd door de arbeidsmarkinstroom van scboolverlaters. De arbeidsmarktinstroom vanuit het initiele en bet post-initielle onderuijs, verbijzonderd naar opleidingscategorie. komt aan de orde in paragraaf 2.4 .

\subsection{Uitbreidingsvraag}

\section{Beroepen}

Zoals uit tabel 1.1 reeds naar voren kwam, wordt voor de periode 2001-2006 een gemiddeide werkgelegenheidsgroei van $1,2 \%$ verwacht. Na cle sterke groei van de werkgelegenheid in de jaren negentig, keren we darmee terug natar her grocitempo van de jalren tachtig.".

Terwijl de groei van de totale werkgelegenheid voomal wordt bepald doon cle internationale conjunctuur, lijken de verschuivingen van cle samenstelling van cle werkgelegenheid nat bedrijlssector. bercep en opleiding vooral een structureel killakler le helben. watrbij twee belangrijke trends een rol spelen ".

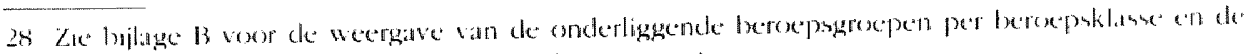
onderhiggende opleidingstypen per opleidingscatcegric

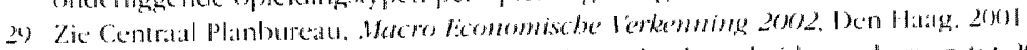

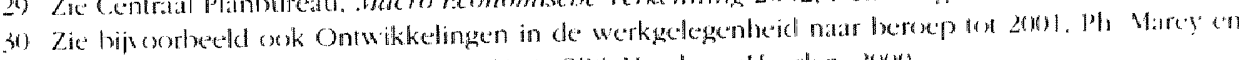

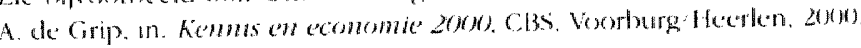


Tabel 2.1

Uitbreidingsvraag naar beroepsklasse, in aantal en als percentage van de werkgelegenheid, 2001-2006

\author{
Beroepsklasse \\ Pedagogische beroepen \\ Culturele beroepen \\ Agrarische beroepen \\ Technische en industrieberoepen \\ Transportberoegen \\ Merlische en paramedische beroepen \\ ficonomisch-administratieve beroepen \\ Informaticaberoepen \\ Social-culturele beroepen \\ Verzorgende en dienstverlenende beroepen \\ Openbare orde- en veiligheidsberoepen \\ Totalal (over alle beroepen)
}

Aantal
13.500
11.000
-18.000
-1.000
10.500
17.500
223.500
31.000
36.500
35.000
3.500

425.000

Totaal

$\%$

Gem. jaarlijks

$\%$

0,7

1,5

$-1,5$

$-0,0$

0,6

0,8

2,1

2,8

3,2

0.6

0,7

1.2

Bron: ROA(POA)

Enerzijds ontwilkkelt de Nederlandse economie zich steeds meer in de richting van een diensteneconomie: zowel de afzetmarkten als de werkgelegenheid zijn onderhevig aan wat wel wordt aangeduid als een 'tertiairisering' van de economie. Deze trend wordt versterkt doordat de productiviteitsgroei in de dienstensector achterblifft bij de industrie". Bovendien richten industriële bedrijven zich steeds meer op hun kernactiviteiten, waardoor er een uitbesteding plaatsvindt van activiteiten (schoonmaak, catering, en dergelijke) aan gespecialiseerde bedrijven in de commerciële dienstverlening. Anderzijds is er ook sprake van een opkomende kenniseconomie, met als gevolg een 'upgrading' van het gevraagcle opleidingsniveau binnen vrijwel alle sectoren van de economie.

I lit talxel 2.1 blijkt dat de voortschrijglende tertiatrisering van de Necterlandse economie niel alleen gevolgen heeth voor cle werkgelegenheidsontwikkelingen natr sector, matr ook 100 tuting $\mathrm{kom}$ in de verschuivende beroepenstructuur van de werkgelegenheid. De sierke gerei in de werkgelegenheid voor sociaal-culturele beroepen, informaticaberopen en economisch-administratiene beroepen in de periode 1096-2000 steekt al legen de lrige groei van lechniscbe en industrieberoepen en de afname in de werkgelegenheid in agrarische beroepen. De\% groeiverschillen zijn mede gebaseerd op de verschuiving van cle sectorale werkgelegenheid in de richling van de clienstverlening len kosile van de landloouw en industrie, zoals in hoofdstuk l reeds natar voren $\mathrm{kwam}$.

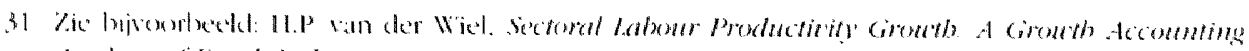

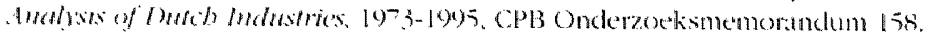


Figuur 2.1

Uitbreidingsvraag naar beroepsklasse, prognose 2001-2006 en realisatie 1996-2000, als gemiddeld jaarlijks percentage van de werkgelegenheid

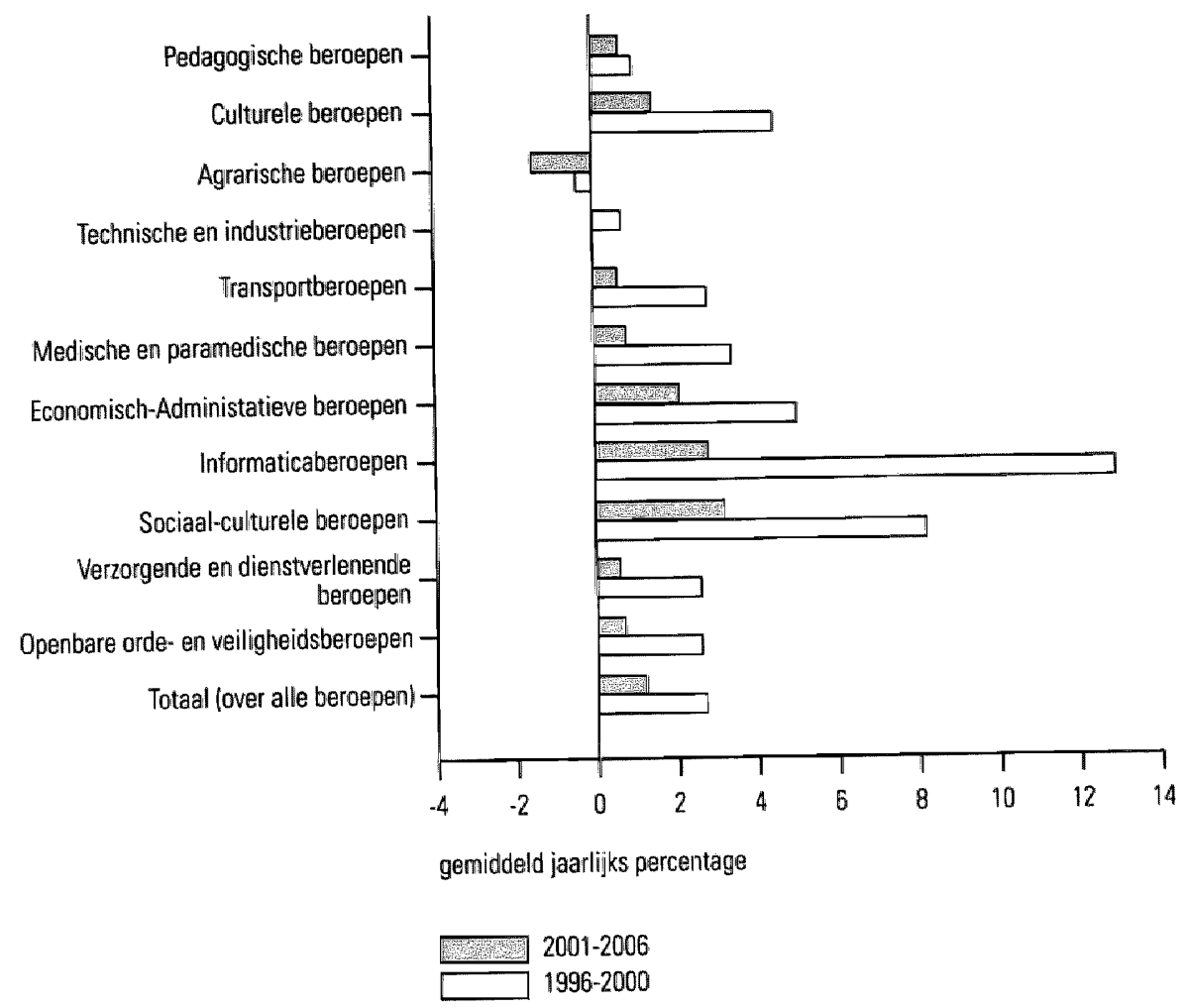

Figuur 2.1 latat zien clat voor de periode 2001-2006, in vergelijking met de altgelopeen jaren, over de hele breedte van de arbeidsmarkt een vertriging van het grocitempo vin de werkgelegenheid word verwacht. Het beeld voor de relatieve ontwikkelingen van beroepen bliff echter naar verwachting hetzelfde. Hierbij komt de werkgelegenlueidsgroei voor technische en industrieberoepen zells tor stilstand. Binnen beroepskbasien kunnen er overigens tussen de onderliggende beroepsgroepen nog ilanzienlijke verschillen optreden. Bij de informaticaberopen bijvoorbeeld, is er sprake van een hoge vithreidingsvratag voor informatici $(5,2 \%)$ en tegelijkertijd een krimpende werkgelegenheid woor tecbnisch systeemanalisten $(-1,8 \%)$.

\section{Opleidingen}

De werkgelegenheidsontwikkelingen van de verschillende opleidingscaltegrièn, zoals wergegeven in tabel 2.2 en figutur 2.2 . Ionen de cumulatie van de twee hierboven besproken trends: de tertiairisering van de sectorale werkgelegenheidsstructum en de upgrading van de beroepenstructur binnen de diverse bedrifssectoren De tertiairisering wordt nog eens versterkt door de geringe groei van de productiviteit in de dienstensector en de 'outsourcing' van taken die buiten de kernactiviteiten van inclustrièle 
bedrijuen vallen aan de commerciële dienstverlening. Ten slotte wordt ook het upgradingsproces van de beroepenstructuur in de verschillende sectoren versterkt doordat er in veel beroepsgroepen sprake is van toenemende kwalificatie-eisen. Door het samenspel van deze ontwikkelingen krijgt Nederland steeds meer het karakter van een kennisintensieve diensteneconomie.

Tabel 2.2

Uitbreidingsvraag naar opleidingscategorie, in aantal en als percentage van de werkgelegenheid, 2001-2006

Opleidingscategorle

Basisonderwis

VMBO theorie

WMBO Landloow en techniek

MMBO economie

VMBO vertorging

HAVOMWO

MBO Landbouw en techniek

MBO economie

MBO dienstverlening en gezondheidszorg

HBO landbouw en tecluniek

HBO economie

HBO onderwijs en sociaal-cullureel

HBO pillamedisch

Wo landbouw en techniek

Wo economie

Wo letteren en social-cultureel

Wo medisch

Totial (over alle beroepen)

Brent ROACPON

$\begin{array}{rrr}\text { Aantal } & \text { Totaal } & \text { Gem. jaarlijks } \\ & \% & \% \\ -121.500 & & -5,2 \\ 5.000 & -23 & 0,2 \\ -58.000 & 1 & -2,5 \\ -11.500 & -12 & -1,2 \\ -15.000 & -6 & -1,7 \\ 59.000 & -8 & 3,0 \\ 109.500 & 16 & 2,0 \\ 63.500 & 10 & 1,5 \\ 52.500 & 8 & 1,4 \\ 33.000 & 7 & 2,2 \\ 58.500 & 11 & 3,5 \\ 50.500 & 19 & 1.8 \\ 29.500 & 9 & 4,1 \\ 19.500 & 22 & 2,6 \\ 55.500 & 14 & 5.1 \\ 37.000 & 28 & 3,9 \\ 1.000 & 20 & 0,3 \\ 425.000 & 2 & 1,2 \\ & & \end{array}$

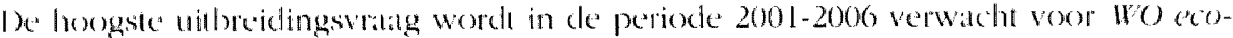
nomic, lerwijl de grootste werkgelegenheidskrimp word voorzien voor mensen met

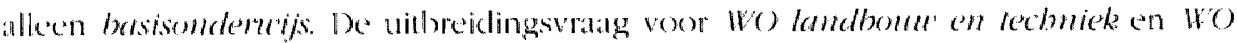

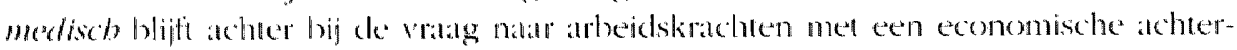
gromd. Hierme word de trend uit de perionde 1996-2000 voortgezet, watarin de werk-

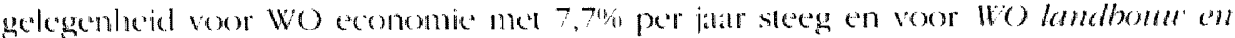

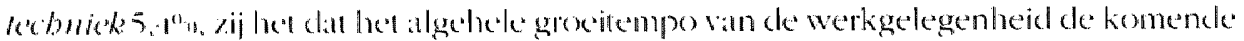

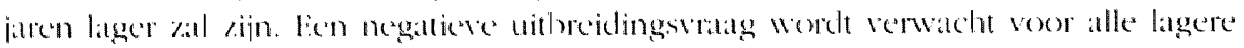

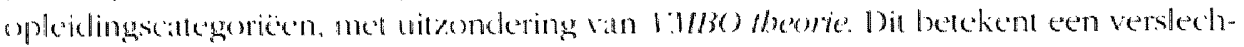

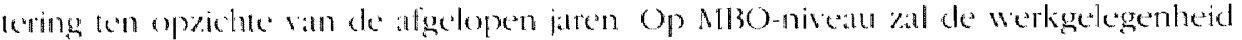

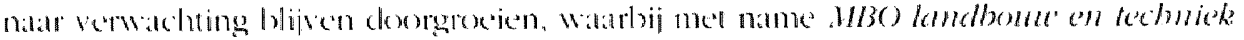

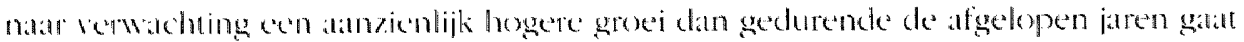

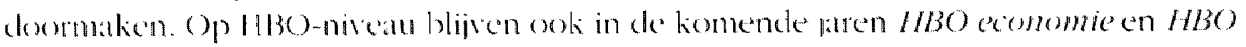

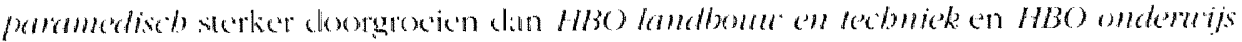

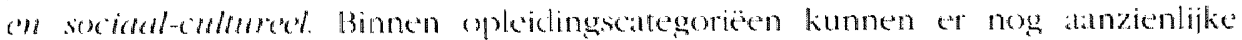


verschillen optreden. Bij WO landbouw en tecbmiek bijvoorbeeld, is de uitbreidingsvraag voor WO landbouw en milieukunde $2,4 \%$ en voor WO informatica en bestumlijke informatiekunde $8,7 \%$.

\section{Figuur 2.2}

Uitbreidingsvraag naar opleidingscategorie, prognose 2001-2006 en realisatie 1996-2000, als gemiddeld jaarlijks percentage van de werkgelegenheid

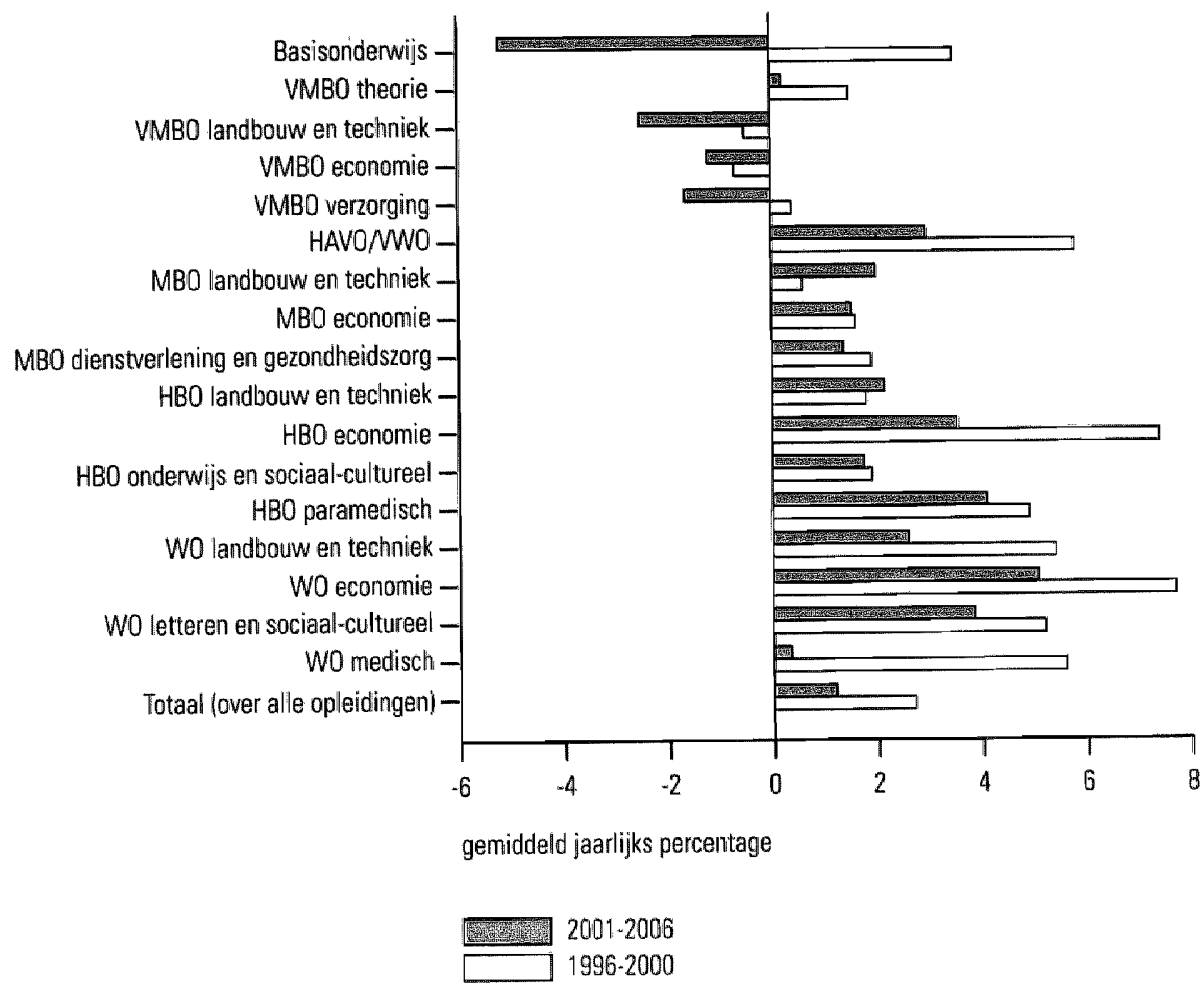

\subsection{Vervangingsvraag}

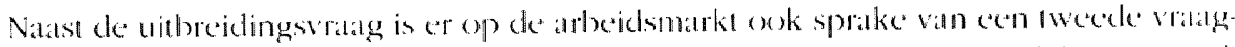

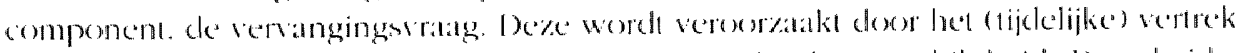

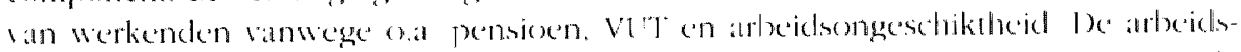
plateren die door dit vertrek vrijkemen dienen. tenzij er sprake is van een krimpende

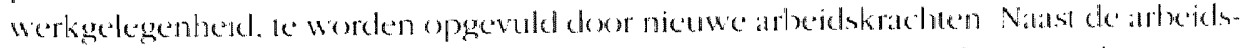

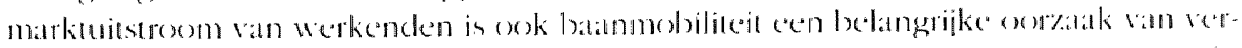

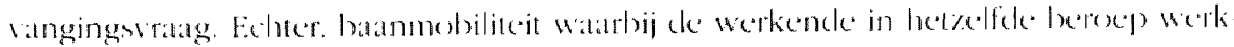

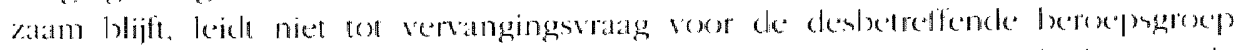

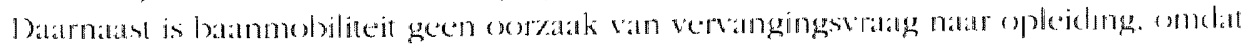
de opleidingsichtergrond wan werkenden met de overstap nata de andere batan inumeres

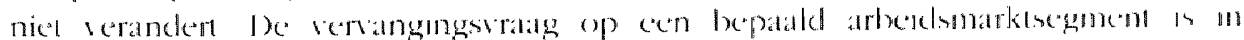


belangrijke mate afhankelijk van de leeftijdsopbouw en de geslachtsverdeling van het personeelsbestand. Daarnaast beinvloeden de arbeidsomstandigheden de omvang van de vervangingsvraag. Hier zal nader op worden ingegaan in hoofdstuk 5 . In deze paragraaf gaat de aandacht wit naar het beschrijven van de verwachte ontwikkelingen van de vervangingsvraag naar beroep en opleiding.

\section{Beroepen}

Wanneer het beroep van de werkenden het uitgangspunt is, bedraagt de totale vervangingsvraag ruim 1.070 .000 werkenden. Dit komt neer op een jaarlijks gemiddeld percentage van 3,0\% van de werkgelegenheid. Dit geeft aan dat de vervangingsbehoefte in het algemeen een belangrijkere vraagcomponent is dan de uitbreidingsvraag. Uit figuur 2.3 blijkt dat de vervangingsvraag, ondanks de verdergaande vergrijzing, naar verwachting nauwelijks toeneemt ten opzichte van de voorbije periode, toen de vervangingsvraag over alle beroepen $2,9 \%$ was. Dit zou erop kunnen duiden dat de uitstroombeperkende maatregelen bij oudere werknemers en bij vrouwen van middelbare leeftijd die kinderen krijgen, enigszins hun vruchten beginnen af te werpen.

De laagste verwachte vervangingsvraag hebben de informaticaberoepen, waarschijnlijk medle door het relatief jonge personeelsbestand in deze beroepsklasse (zie hoofdstuk 5). Uit figuur 2.3 blijkt dat ook de vervangingsvraag voor deze beroepsklasse naar verwachting zal stijgen ten opzichte de periode 1996-2000.

Tabel 2.3

Vervangingsvraag naar beroepsklasse, in aantal en als percentage van de werkgelegenheid, 20012006

\section{Beroepsklasse}

Palagogische beropent

culturele beroepen

Agrarische beroepen

Iechmische en industrieberoepen

Tramsporlberogen

Medische en paranedische beroejen

Ronomisch-adirinistratieve beroepen

lifomaticibersemen

Siociatial-culurele heropen

Verrorgende an dienstverlenender berwen

Opentlate onde- en veiligheidsheropen

Total (ower alle beroenent)

Brom: RON(POA)

$\begin{array}{rrr}\text { Aantal } & \begin{array}{r}\text { Totaal } \\ \%\end{array} & \begin{array}{r}\text { Gem. jaarlijks } \\ \%\end{array} \\ 77.400 & & \\ 23.000 & 21 & 3.9 \\ 45.000 & 16 & 3.0 \\ 232.600 & 17 & 3.3 \\ 54.000 & 15 & 2,9 \\ 72.700 & 14 & 2.6 \\ 338.100 & 18 & 3.3 \\ 18.100 & 16 & 3.1 \\ 27.100 & 9 & 1,7 \\ 161.800 & 13 & 2,4 \\ 16.400 & 15 & 2.8 \\ 1071.800 & 16 & 3.1 \\ & & 3.0\end{array}$

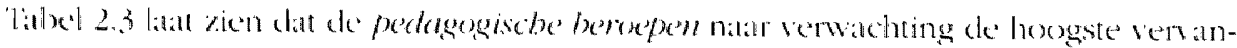

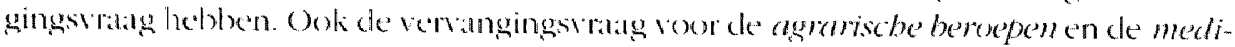

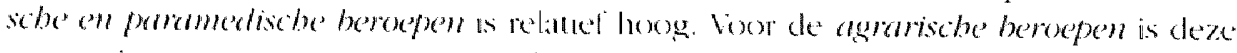

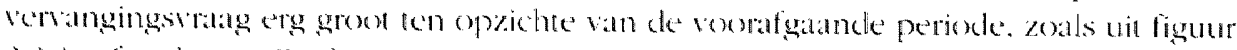

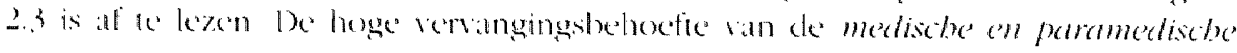


beroepen concentreert zich met name in de beroepsgroepen verpleegbulpen en leerling verpleegkundigen, verplegenden en doktersassistenten, en therapeuten en verpleegkundigen.

Hoewel de vervangingsvraag voor de technische en industrieberoepen naar verwachting gemiddeld is voor de komende jaren, geldt niet voor alle onderliggende beroepsgroepen binnen deze klasse. Veel beroepen binnen de techniek en industrie vertonen weliswaar grote overeenkomsten als het gaat om de personeelskarakteristieken (o.a. weinig werkzame vrouwen) en economische vooruitzichten (conjunctuurgevoelig). toch zijn er ook de nodige verschillen die er voor zorgen dat sommige beroepsgroepen binnen deze klasse duidelijk hogere of lagere vervangingsvaag kunnen verwachten. Vooral de zwaardere beroepen, aangaande de arbeidsomstandigheden (werken met lawaai, werken met trillend gereedschap, kracht zetten, etc.), hebben een relatief hoge vervangingsvraagbehoefte.

Figuur 2.3

Vervangingsvraag naar beroepsklasse, prognose 2001-2006 en realisatie 1996-2000, als gemiddeld jaarlijks percentage van de werkgelegenheid

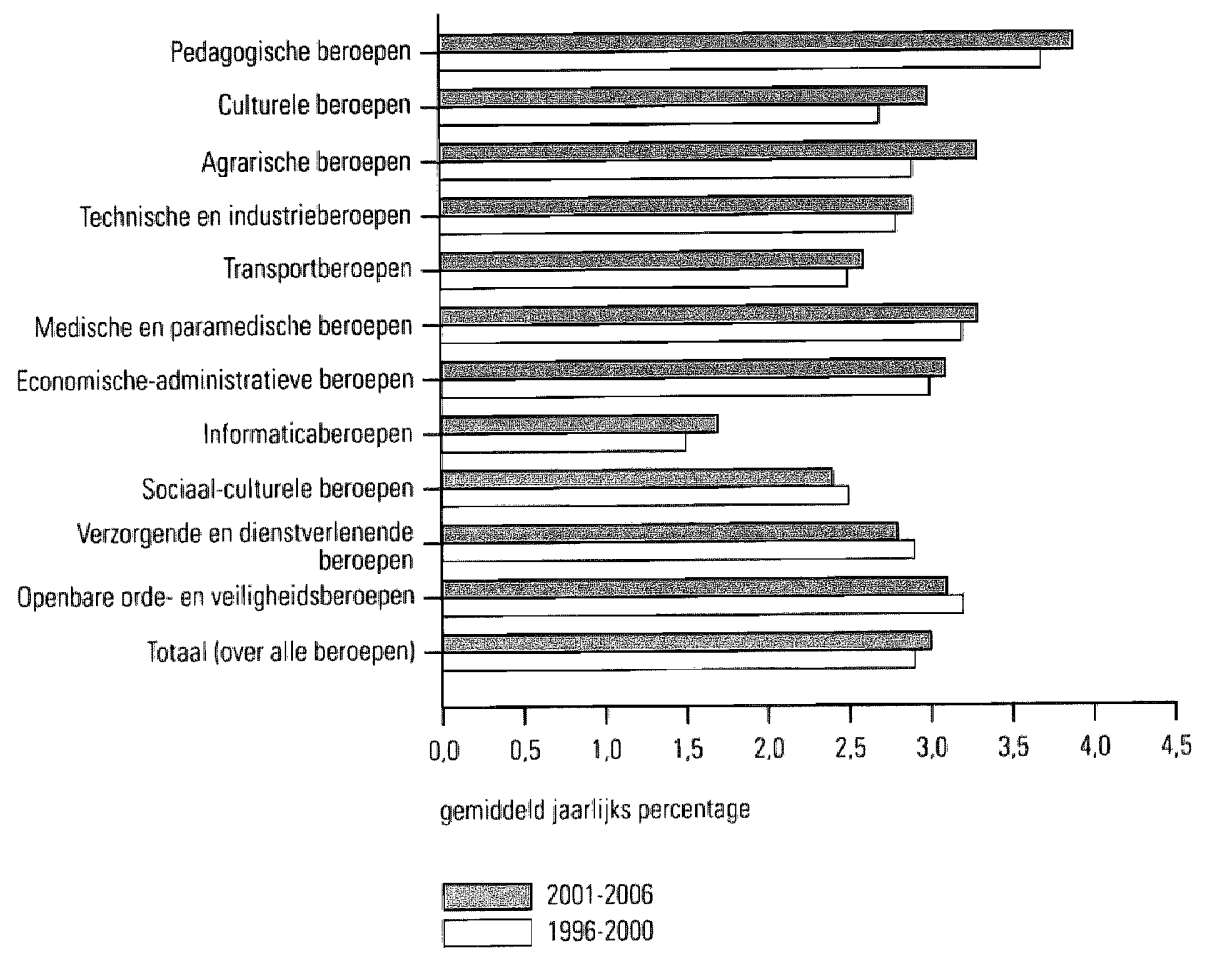

Bron: ROAPP(ON 
De beroepsklasse transportberoepen vormt één van de kleinere beroepsklassen en geeft met $2,6 \%$ jatarlijks gemiddeld een relatief lage vervangingsvraagbehoefte te zien. Deze lage verwachte vervangingsvraag komt voornamelijk woor rekening van de beroepen laders en lossers, cbauffeurs en stewards. Een aantal beroepen onttrekt zich aan dit algemene beeld van de klasse van de transportberoepen en heeft naar verwachting juist wel een relatief hoge vervangingsvraag. Binnen de economiscb-administratieve beroepen hebben twee grote beroepsgroepen, namelijk de receptionisten en administratieve employees en de boekhouders en secretaresses, een relatief hoge verwachte vervangingsvraag, terwijl andere beroepsgroepen, bijvoorbeeld met betrekking tot de accountancy en de organisatieadvisering, slechts een relatief lage verwachte vervangingsvraag hebben.

\section{Opleidingen}

Bij cle vervangingsvraag voor opleidingen speelt naast de uitstroom, die als gevolg van VUT, arbeidsongeschiktheid en pensioen ontstat, ook de doorstroom van werkenden die doorleren een rol. Hel gat hierbij, zoals in hoofdstuk 1 reeds is angegeven naar verwachting om ca. 85.000 personen gemiddeld per jaar. In tabel 2.4 is per opleidingscategorie weergegeven het aantal arbeidsplaatsen clat in de periode 2001-2006 dient te worden opgevuld ten gevolge van de vervangingsvraag. Dit totale aantal arbeiclsplaatsen is weergegeven als percentage van het aantal werkenden met de desbetreffende opleidingsachtergrond. De arbeidsmarkt als totat heeft naar verwachting een vervangingsvraag ter grootte van ruim 1.365 .000 werkenden. Dit komt neer op 3.7\% van de werkgelegenheid. In figuur 2.4 is ter vergelijking ook de vervangingsvraag in de periode 2001-2006 opgenomen. Deze ligt met 3,8\% gemiddeld per jaar op vrijwel hetzelfele niveau als in de prognoseperiode.

De relatief grootste vervangingsvraaghehoefte valt waar te nemen bij basisonderuijs en HAVO/VWO De vervangingsvalag van 172.300 mensen met alleen basisonderutis is

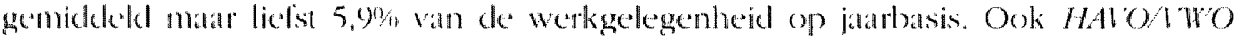
hoeti met $4,6 \%$ cen erg hoge vervangingsvatag. De dercle algemene opleidings-

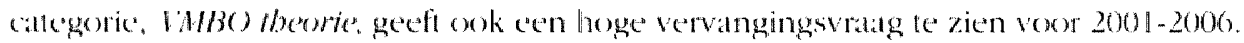
Overigens blijkt uit liguu $2 .+$ dat de vervangingsvatag voor basisonderwijs natar

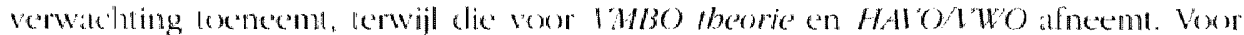

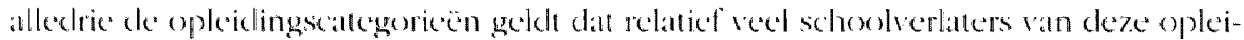

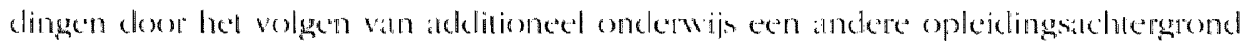

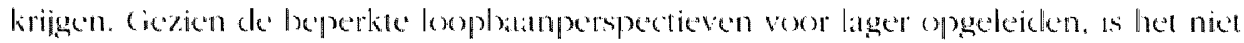
verwonderlijk dat zij hun arbetidsmarktpositie trachen te verbeteren dox het volgen

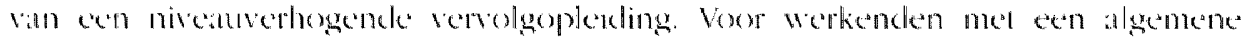

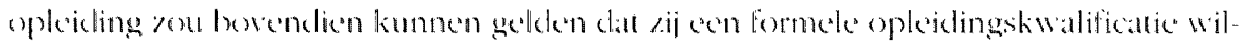

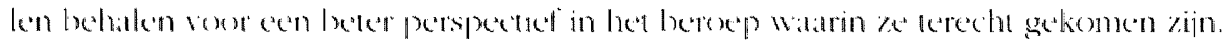


Tabel 2.4

Vervangingsvraag naar opleidingscategorie, in aantal en als percentage van de werkgelegenheid, 2001-2006

\section{Opleidingscategorie}

Basisonderwijs

MBBO theorie

WMBO landbouw en techniek

VMBO economie

VMBO verzorging

HAVONWO

MBO landbouw en techniek

MBO economie

MBO dienstverlening en gezoncheidszorg

HBO landbouw en techniek

HBO economie

HBO onderwijs en sociaal-cultureel

HBO paramedisch

Wo landbouw en techniek

Wo economie

wo letteren en sociaal-cultureel

wo medisch

Totaal (over alle opleidingen)
Aantal:

172.300

103,900

87.000

36.200

40.800

95.600

199.500

152.100

139.300

46.600

37.500

118.000

21.200

16.600

20.100

25.100

10.900

1.366 .600

$\begin{array}{rr}\text { Totaal } & \text { Gem. jaarlijks } \\ \% & \%\end{array}$

33

5,9

4,0

3.3

3.5

4,1

4.6

3,5

3,5

3,5

3,0

2,3

3.9

3,0

2.3

2,0

2,7

3.2

3.7

Bron: ROA(POA)

Uit figuur 2.4 valt verder op dat de vervangingsvaag voor VMBO economie sterk sitigl ten opzichte van de voorafgaande periode. Voorts is de vervangingsvraag voor $H B B($ ) economie laag, evenals de vervangingsvratag voor de opleidingscategorieen op het woniveau, met uizondering van WO medisch. Vooral voor de opleidingstypen WO kand-

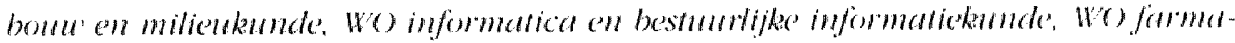

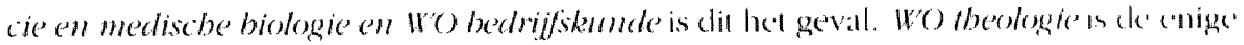
wetenschappelijke opleiding met een hoge verwathe vervangingsvalag. Dit is ver een deel te verklaten doordat het belang van doorlecelers von de vervangingstraiag loij het wo klein is, zoals verwacht kan worden. Dit neemt nied weg dat enen richoingveran-

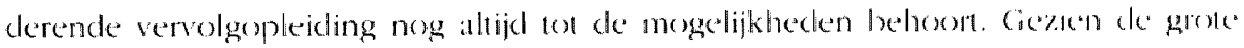

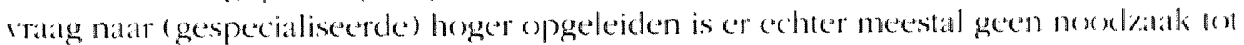
het rolgen van een richtingveranderende opleiding: es is immers voldende werk. 
Piguur 24

Vervangingsvraag naar opleldingscategorie, prognose 2001-2006 en realisatie 1996-2000, als gemiddeld jaarlijks percentage van de werkgelegenheid

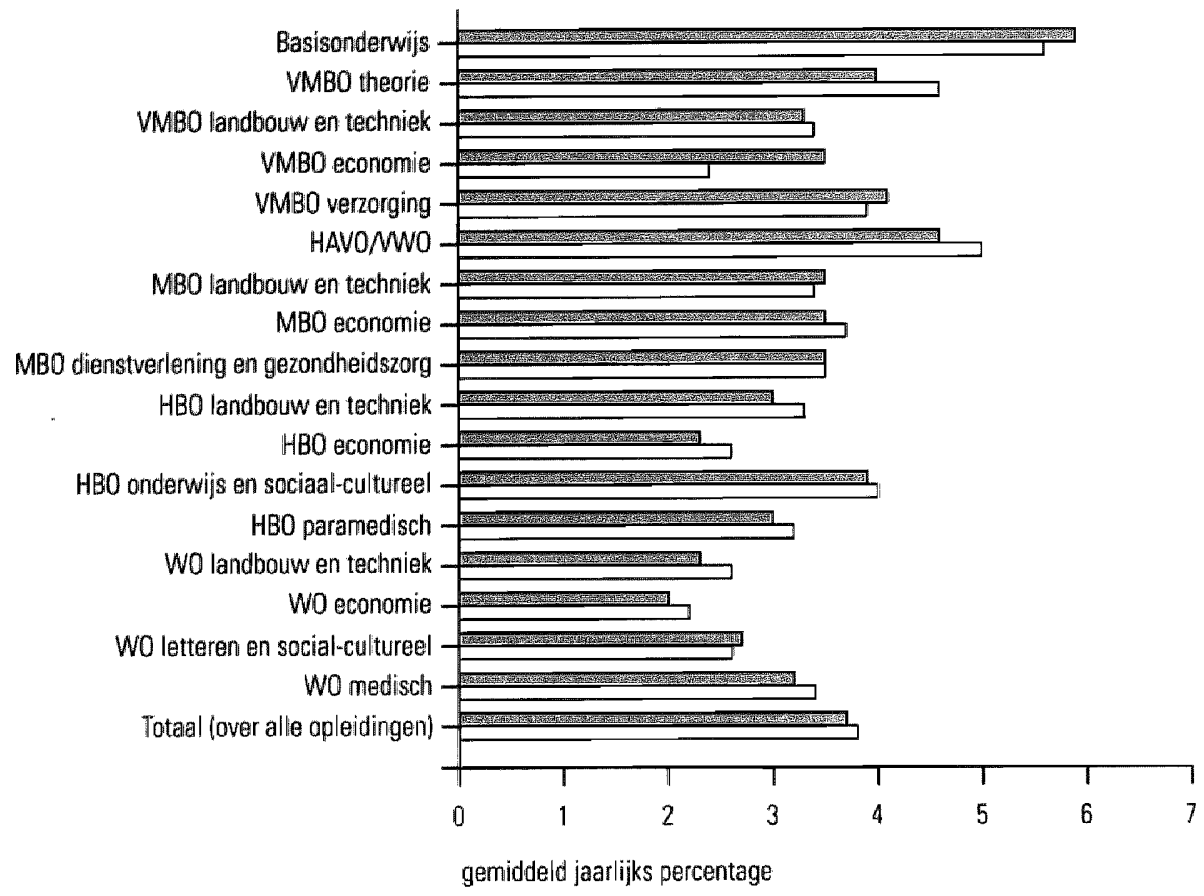

2001-2006

$1996-2000$

Bron: ROA(POA)

\subsection{Baanopeningen}

De totale vriatg natar nicuwkomets op de arbeidsmatrt word weergegeven door de batanopeningen Onder batanopeningen wordt verstatan de vrijkomende loanen per beroepsgroep of oplevelingstype die beschikbatar zijn voor nieuwkomers. Het aantal batanopeningen kan clerhalve worden bepaald door de som van de positieve witbredingswatag en de vervangingsvratag. In het geval van exen verwachte werkgelegen-

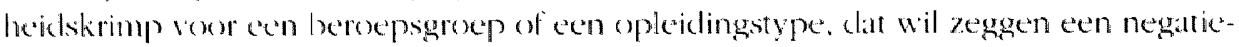

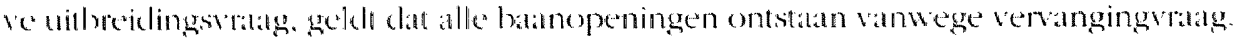


Tabel 2.5 laat zien dat er in de periode 2001-2006 naar verwachting ruim 1.5 miljoen baanopeningen voor nieuwkomers zullen ontstaan Dit komt neer op $4.1 \%$ van de werkgelegenheid per jaar. De vervangingsvraag is daarmee verantwoordelijk voor gemiddeld $70 \%$ van alle baanopeningen.

Uit figuur 2.5 blijkt verder dat het percentage baanopeningen voor alle beroepsklassen een grote daling zal vertonen ten opzichte van de afgelopen jaren. Vooral voor de informaticaberoepen en de sociaal-culturele beroepen wordt een zeer grote daling verwacht. De beroepsklasse sociaal-culiurele beroepen zal naar verwachting een relatief hoog percentage baanopeningen blijven vertonen, namelijk $5.4 \%$ gemiddeld per jaar. Deze grote vraag is vooral het gevolg van een hoge uitbreidingsvraag. Dit is voor de sociaal-culturele beroepen de dominante vraagcomponent, want het aandeel van de vervangingsvraag in de baanopeningen is slechts $43 \%$.

Daarentegen zal de beroepsklasse van informaticaberoepen terugvallen natr een gemiddeld percentage verwachte baanopeningen. De totale vraag naar nieuwkomers op de arbeidsmarkt komt uit op 4,4\% gemiddeld per jaar. Daarbij is hel andeel van de vervangingsvraag in de baanopeningen slechts $39 \%$ is. Het merendeel van de baanopeningen voor nieuwkomers valt derhalve toe te schrijven an de uitbreidingsvrata. De techniscb systeemanalisten onttrekken zich enigzins aan het beeld van de klasse, met een erg laag percentage baanopeningen.

De verwachte baanopeningen voor de pedagogische beroepen bedragen $4,9 \%$ gemicldeld op jaarbasis. Voor de pedagogische beroepen geldn dat de vervangingsvraag de dominante vraagcomponent is, hetgeen mede te verklaren is uit de relatief hoge leeftijcl van de docenten. Sommige beroepsgroepen ontrekken zich aan het gemididelde beeld van de klasse. Zo geld bijvoortbeeld dat de docenten economisch-administratione takken (le graads) een erg hoog percentage baanopeningen te zien geefi, kerwij] de ztreminstractears relatief weinig batanopeningen mogen verwachten.

De culturele beroepen hebben in de periode $2001-2006$ een gemiddeld jaarlijks percentage baanopeningen voor nieuwkomers op de arbeiclsmarki van $4.4^{\text {th }}$ van de werkgelegenheidl. Wederom is de vervangingsvrata, met een danded van $65 \%$, de vormatam-

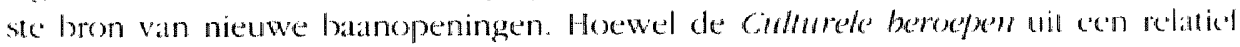
klein aanal beroepsgroepen bestat. gekd hier een zekere diversiteil Bibliobecarisen

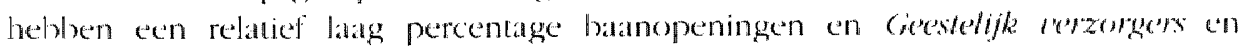
crestelibeen hebben datrenkegen erg een hoog percentage batanespeningen. 
Een erg lage uitbreidingsvraag gecombineerd met een hoge vervangingsvraag resulteert voor de agrarische beroepen in een laag percentage baanopeningen. Er ontstaan naar verwachting baanopeningen voor nieuwkomers binnen dit arbeidsmarktsegment ter grootte van slechts 3,4\% van de werkgelegenheid. Deze banen komen vrijwel uitsluitend voor rekening van de vervangingsvraag (94\%). Dit zou vooral het gevolg kunnen zijn van het grote aandeel van werkenden op oudere leefrijd en de zware arbeidsomstandigheden (zie hoofdstuk 5). Milieubygienisten en agrariscb vertegenuoordigers is de enige beroepsgroep binnen de agrariscbe beroepen met relatief veel baanopeningen. Matar het aantal werkenden van deze beroepsgroep is vrij klein binnen de klasse.

Talbel 2.5

Baanopeningen naar beroepsklasse, in aantal en als percentage van de werkgelegenheid, 2001-2006

Beroepsklasse

Pedagogische beroepen

Cullurele beroepen

Agrarische beroepen

Technische en industrieberoepen

Transportberoepen

Medisclue en paramedische beroepen

Economisch-administratieve beroepen

Informalicaberoepen

Social-cultume beroepen

Verzorgende en dienstwerlenende beroepen

openbare orde- en veiligheidsheroeven

Totalal (over alle betoepen)

Bron: ROACP(OA)
Aantal

97.800

35.300

47.700

267.300

66,900

93.500

576.100

50.300

63.600

205.600

21.200

1.525 .300

\section{Total}

Gem. Jaarlijks

$\%$

$\%$

Belang vervangings

4,9

4,4

3,4

3.3

3,2

4,2

5,1

4,4

5,4

3.5

3.9

4.1 vraag
$\%$

79

65

94

87

80

78

59

36

43

79

78

70

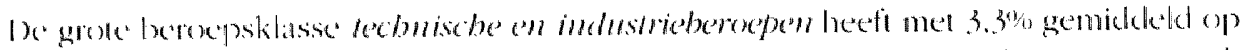
jatriasis een lalag percentage baanopeningen Het grootste deel van deze ralag wordt wederom gevormol deor de vervangingsvatag. Een atantal grote beroepsgroepen met

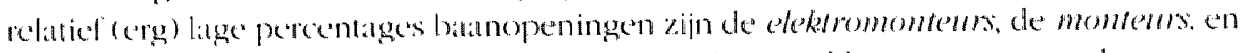

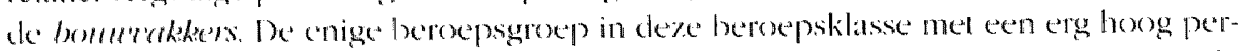

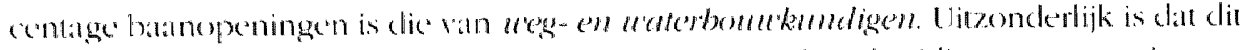

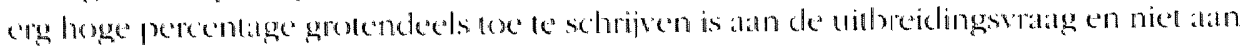

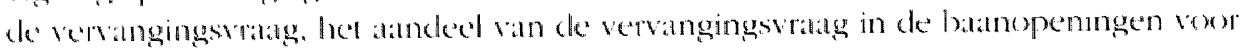

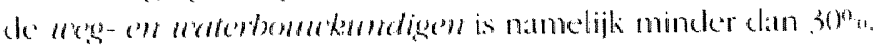

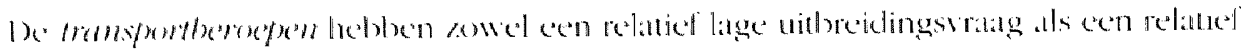

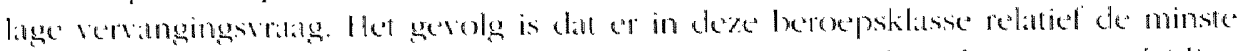

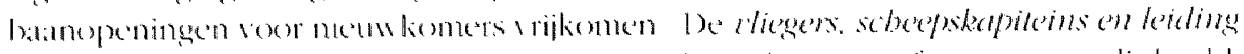

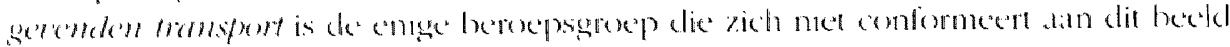


Voor deze beroepsgroep wordt juist een hoog percentage baanopeningen voorspeld.

Voor de beroepsklasse van medische en paramediscbe beroepen is het aantal baanopeningen gemiddeld 4.2\% van de werkgelegenheid op jaarbasis. Met een belangrijk aandeel van vrouwen in het personeelsbestand en relatief zwaar (lichamelijk) werk, is hel niet verwonderlijk dat de vervangingsvraag ook voor deze klasse de belangrijkste bron van baanopeningen is. De verwachting is niet hetzelfde voor alle beroepen binnen de klasse. De beroepsgroep binnen de klasse met het laagste percentage baanopeningen is verpleegbulpen en leerling-verpleegkundigen. Een hoog percentage baanopeningen wordt daarentegen verwacht voor de beroepsgroep therapeuten en verpleeghandigen.

De grootste beroepsklasse in aantal werkenden geeft ook een van de hoogste percentages baanopeningen te zien. De economisch-administratieve beroepen bieden niall verwachting werk aan ca. 575.000 nieuwkomers. Dit is matr liefst 5,1\% gemiddeld per jaar. Vooral de accountants, de leidinggevenden, de managers, en de receptionisten en administratief emplovees tonen erg hoge percentages baanopeningen. Dilarentegen is het percentage baanopeningen voor de verzekeringsagenten erg laag.

\section{Figuur 2.5}

Baanopeningen naar beroepsklasse, prognose 2001 en realisatie 1996-2000, als gemiddeld jaarlijks percentage van de werkgelegenheid

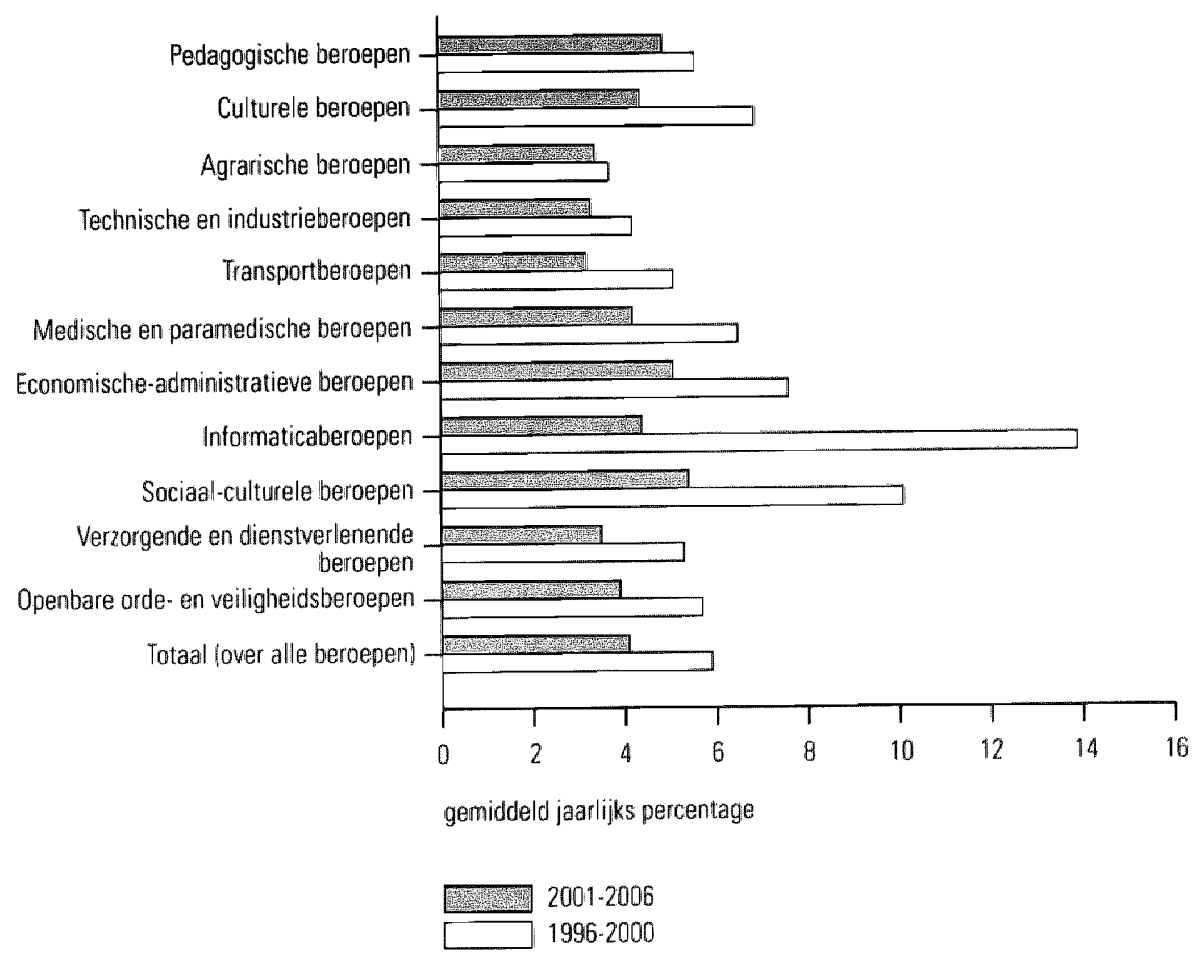


Voor de beroepsklasse van de verzorgende en dienstvertenende beroepen geld dat de vervangingsvraag verantwoordelijk is voor $79 \%$ van het totale aantal baanopeningen. Deze vraag naar nieuwkomers bedragt naar verwachting gemiddeld jaarlijks 3,5\% van de werkgelegenheid. De beroepsklasse geeft zelf een zeer divers beeld te zien: erg lage percentages baanopeningen voor de bulpkracbten boreca en verzorging en de beroepsgroep verzorgend personeel, terwijl de ziekenverzorgenden darantegen een erg hoog percentage baanopeningen heeft. verder geldt ook niet voor alle onderliggende beroepsgroepen dat de vervangingsvraag de dominante vraagcomponent is. Voor de vakkenuullers is bijvoorbeeld de relatief hoge uitbreidingsvraag aanmerkelijk belangrijker.

Zowel de uitbreidingsvraag als de vervangingsvraag zijn voor de klasse van openbare orde- en veiligheidsberoepen gemiddeld, evenals bij gevolg het gemiddelde jaarlijkse percentage baanopeningen ter grootte. Enige variatie binnen de beroepsklasse valt waar te nemen. De politie-inspectetus en officiers hebben naar verwachting relatief veel baanopeningen, en de beroepsgroep van politieagenten. onderofficieren en beveiligingsemployees heeft een laag percentage baanopeningen.

\section{Opleidingen}

In tabel 2.6 is per opleidingscategorie de verwachte ontwikkeling van de baanopeningen in de periode 2001-2006 weergegeven. Het aantal verwachte baanopeningen als gemiddeld jalarlijks percentage van de werkgelegenheid is het hoogst voor $H A V O / V W O$, HBO paramediscb en WO economie. Voor HAVO/VWO is het hoge aantal batanopeningen gerelateerl at de vervangingsvrata, die lhoog is vanwege het doorleergedrag van werkenden met de opleidingsachtergrond HAVO/VWO. Daarbij komt nog de hoge uitbreidingsvraag, waturdoor een erg hoge totale vraag naar nieuwkomers ontstat. Voor HBO paramedisch is het grote antal batanopeningen met name toe te schrijven atan de hoge vitheredingsvratig. wilarbij in hel bijzonder de grote vratag natar personen met een

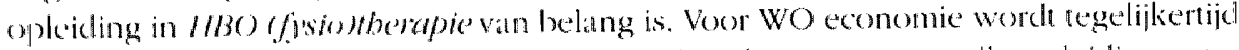

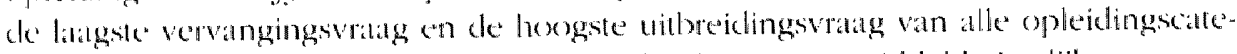

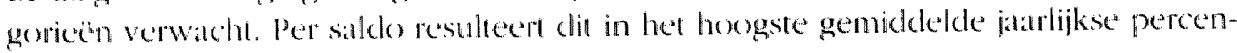
latge verwatche batanopeningen. 
Tabel 2.6

Baanopeningen naar opleidingscategorie, in aantal en als percentage van de werkgelegenheid, 2001-2006

Opleidingscategorie

Basisonderwijs

VMBO theorie

YMBO landbouw en techniek

VMBO economie

WMBO verzorging

HAVONWO

MBO landbouw en techniek

MBO economie

MBO dienstverlening en gezondheidszorg

HBO landlbouw en techniek

$\mathrm{HBO}$ economie

$\mathrm{HBO}$ onderwijs en sociaal-cultureel

HBO paramedisch

Wo landbouw en techniek

Wo economite

Wo letteren en sociaal-cultureel

Wo medisch

Totaal (over alle opleidingen)
Aantal

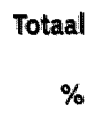

$\%$
Belang

jaarlijks vervangings-

$\%$

$\begin{array}{rr} & \begin{array}{r}\text { Gemiddeld } \\ \text { jaarlljks }\end{array} \\ \% & \%\end{array}$

vraag*
172.300

109.100

91.300

50.300

40.800

154.800

312.500

215.800

212.800

80.400

95.800

174.500

50.500

36.000

75.400

62.000

12.000

2.051 .600

* Is de uitbreidingsvrang negatief, dan is het belang van de vervangingsvrang $100 \%$.

Bron: ROA(POA)

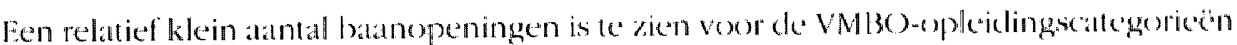
en. opmerkelijk genoeg. WO medisch. Voor deze opleidingscategoricen is ele uillorei-

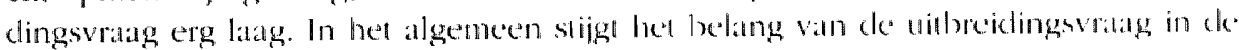

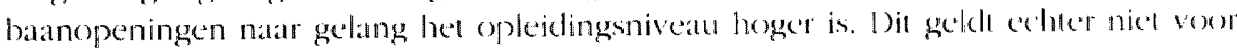
WO medisch.

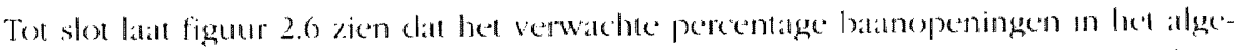

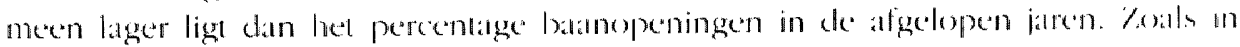

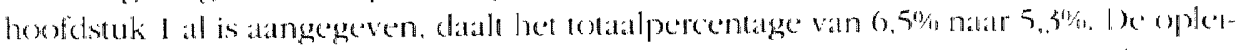

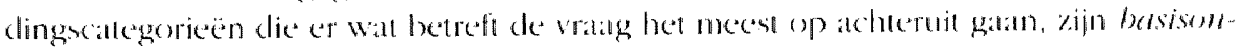

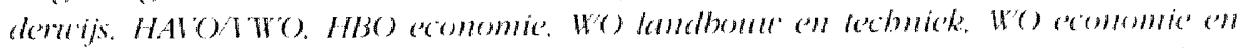

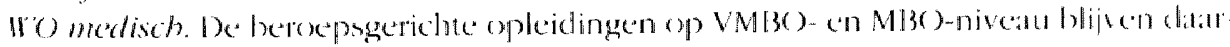
entegen redelijk stabel met betrekking of hel percentage batamepenmgen 
Fiquur 2,6

Baanopeningen naar oplleidingscategorie, prognose 2001-2006 en realisatie 1996-2000, als gemiddeld jaarlijks percentage van de werkgelegenheid

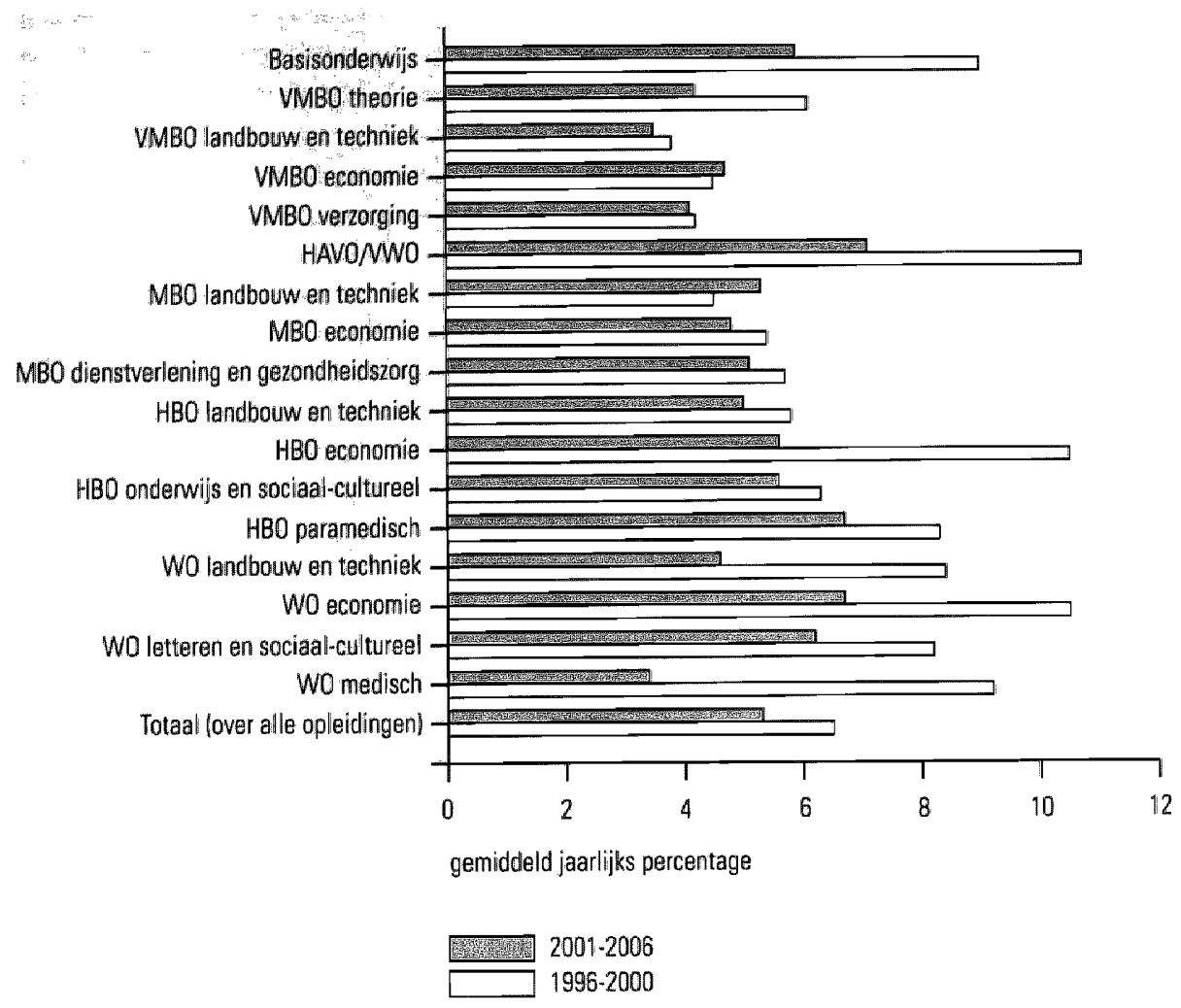

Brom: ROACPOM) 


\subsection{Arbeidsmarktinstroom}

Om een goed beeld te krijgen van de toekomstige situatie op de arbeidsmarkt, dienen naast de ontwikkelingen in de vraag naar arbeid ook de ontwikkelingen van het arbeidsaanbod in kaart te worden gebracht. Binnen dit arbeidsaanbod kunnen een drietal componenten worden onderscheiden: de schoolverlaters, de werklozen en de stille reserve. Voor het bepalen van de toekomstige arbeidsmarkisituatie wordt aangenomen dat schoolverlaters en kortdurig werklozen met elkaar concurreren terwijl langdurig werklozen en de stille reserve een zwakkere arbeidsmarktpositie hebben. Vandaar dat de twee latste groepen buiten beschouwing blijven bij het maken van prognoses van de positie van schoolverlaters op de arbeidsmarki ${ }^{k t}$.

De grootste en belangrijkste component van het arbeidsaanbod bestat wit de voor de komende viff jaar verwachte arbeidsmarktinstroom van schoolverlaters die vanuit het initiële (dag)onderwijs de arbeidsmarkt opstromen. Bovendien worden ook reeds werkenden tot het arbeidsaanbod gerekend indien zij die door middel van post-initieel (avond)onderwijs hun kwalificatieprofiel dusdanig hebben veranderd dat zij vanwege hun gewijzigde opleidingsachtergrond als nieuw anbod op de arbeidsmarkt kunnen worden beschouwd. Daarbij kan gedacht worden aan opleidingen clie het initiělé opleidingsniveau verhogen of opleidingen die de initiële opleidingsrichting wijrigen.

Van 2001 tot 2006 zullen natr verwachting in totaal bijna 1,7 miljoen 'schoolverlaters' 101 de arbeidsmarkt toetreden. Van deze 'schooverlaters' is ca. $75 \%$ affomstig uit her inftiële en ca. 25\% uit het post-initiële onderwijs. In tabel 2.7 worden de instroomprognoses gepresenteerd voor elk van de 17 opleidingscategorieën. Narar verwachting is de groei van schoolverlaters met een $\mathrm{HAVO}$ /VWO-diploma het hoogst. Op een kileine groep na (die direct de arbeidsmarkt opstroomt) hebben de schoolverlaters met de $x^{\circ}$ opleidingsachtergrond eerst een andere opleiding geprobeerd maar zijn datarmee voortijlig gestopt. Het merended van deze schoolverlaters strosm vanwege het vorntijelig

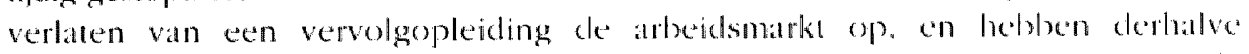
HAVO/VWO als hoogst voltooide initiële opleiding. Een zelfde probleem gelelt vour cke schoolverlaters die slechts basisonderu'ijs heblon genoren".

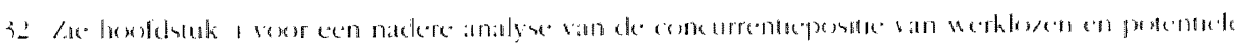

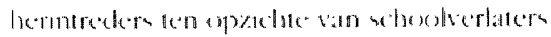

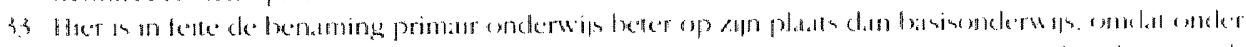

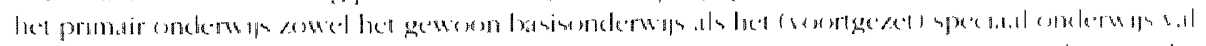

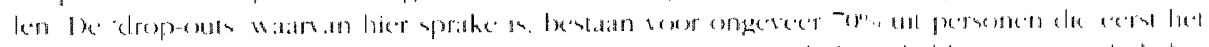

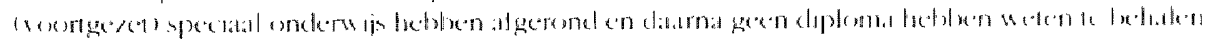
in het hersigenderwis 
Tabel 2.7

Instroom op de arbeidsmarkt naar opleidingscategorie, in aantal en als percentage van de werkgelegenheid, 2001-2006

\section{Opleidingscategorie}

Basisonderwifs

VMBO theorie

VMBO landbouw en techniek

VMBO economie

VMBO verzorging

HALONWO

MBO landbouw en techniek

MBO economie

MBO dienstwerlening en gezondheidszorg

$\mathrm{HBO}$ ]andbouw en lechniek

HBO economie

HBO onderwi|s en sociacl-cultureel

HBO paramedisch

Wo land bouw en techniek

Wo economie

wo letteren en socialal-cultureel

wo medisch

Totaal (over alle opleidingen)
Aantal

134.800

117.000

101.000

60.000

50.500

200.500

234.000

180.000

176.500

50.500

99.000

104.000

30.000

24.500

51.000

40.000

9.500

1.686 .000
Totaal

$\%$

Gem. Jaarlijks

$\%$

4,7

4,5

3,9

5,5

4,9

8,9

4,1

4,1

4,3

3,2

5,7

3.5

4,2

3,3

4,7

4,1

2,7

4.4

Broll: ROA(POA)

De opleidingscategorieën watrvan de instroom in bovenstaande tabel staat weergegeven, bestaan uit verschillende opleidingstypen. De arbeidsmarktinstroom kan binnen dere opleidingscaltegorieèn voor de onderliggende opleidingstypen ianzienlijk versthillen. Zo hecti de opleidingscategorie 1 MBBO economie natar verwachting een hoge arlogiclsmatrkinstrexm. De twee onderliggende opleidingstypen geven exhter een

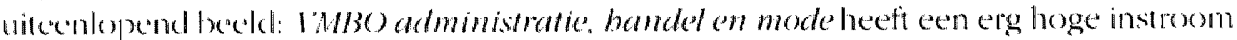
ran schoolverlatters terwijl VMBBO constmptief en letensmiddelentechniek een lage instromn hedt. Iien dergelijke onderliggende diversileit bestalat bij meerdere oplej-

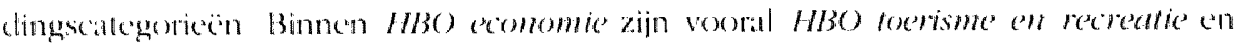

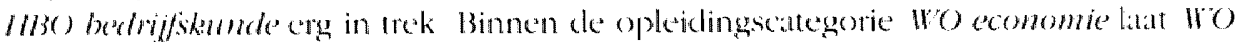
acommanty en belastingen cen lage arbeidsmatktinstrom zien, terwijl binnen de\%e

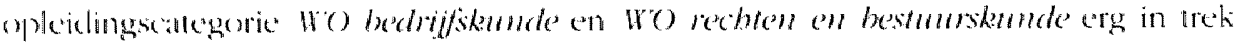
ziin. Ten slote is de verwachte atbeidsmatktinstroom van wo medisch latag, hetgeen samenlangt met de numerus fixus voor leze opleidingen. 
Figuur 2.7

Arbeidsmarktinstroom naar opleidingscategorie, prognose 2001-2006 en realisatie 1996-2000, als gemiddeld jaarlijks percentage van de werkgelegenheid

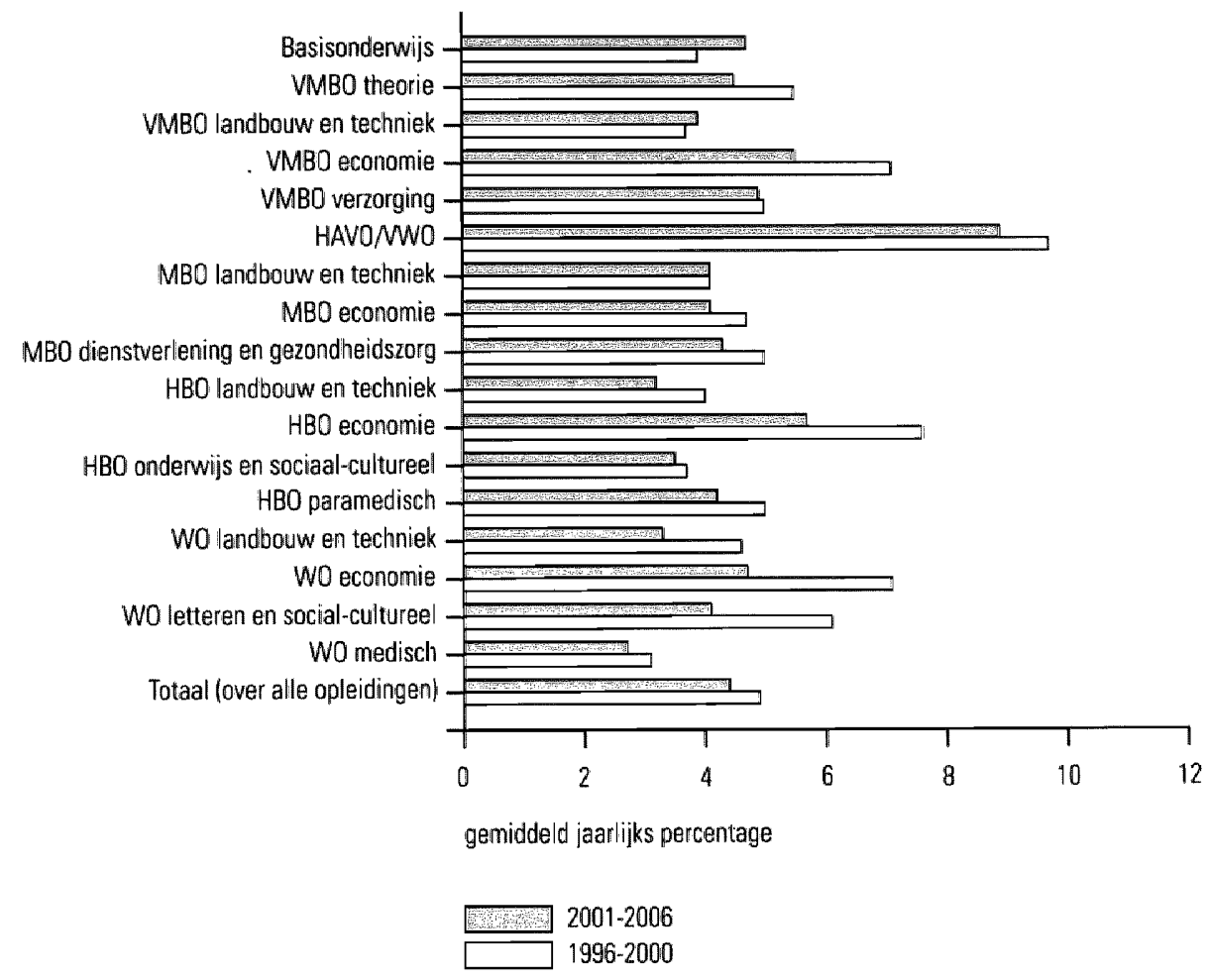

Bron: ROAPOA)

In figuur 2.7 worden de prognoses in een historisch perspecticl gepliallst. In de fighur is te zien dat hoewel de totale instrom op de arlecidsmarkt slechts licht gedatald is, de verschillen voor de afzonderlijke opleidlingscategorieën alanzienlijk kunnen zijn. Ix grooste dalers zijn daarbij natar verwadluing $H B O$ economie en WO economie on W() letleren en sociadal caltureed. Er is bij deze opleiclingscategorieèn colbter nauwelijks sprake van een absolute daling van de instrorm op de arbedsmarkt. De daling wordt

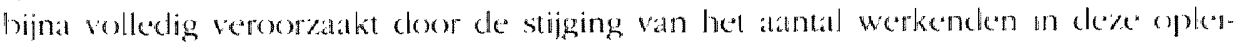

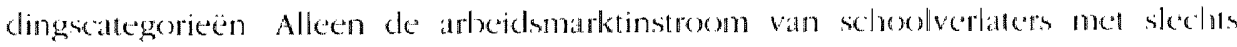

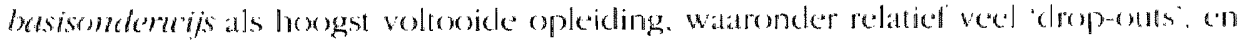

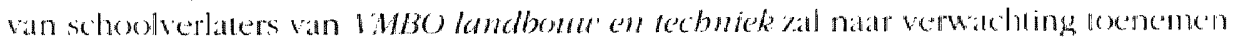

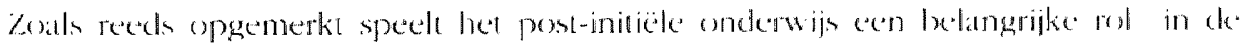

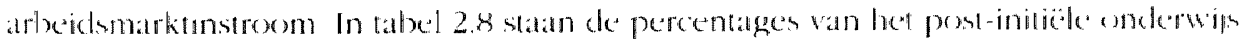
ten opriche van de totale instrom op de arbeidsmarkt 
Tabel 2.8

Arbeidsmarktinstroom van personen van het post-initiële onderwijs per opleidingscategorie, percentage van de totale arbeidsmarktinstroom, 2001-2006

Opleidingscategorie

Post-initieel onderwijs

Basisonderwijs

VMBO theorie

VMBO landbouw en techniek

VMBO economie

VMBO verzorging

HAVONWO

$\mathrm{MBO}$ landbouw en tecliniek

MBO economie

MBO dienstwerlening en gezondheidszory

HBO landbouw en techniek

$\mathrm{HBO}$ economie

$\mathrm{HBO}$ onderwiss en sociaal-cultureel

HBO paramedisch

Wo landlouw en technjek

Wo economie

Wo letteren en sociaal-cultureel

WO medisch

'lotal

Bron: ROA(POA)

Uit deze tabel blijkt dat het post-initiële onderwijs met name een hoog aandeel heeft in cle totale arbeidsmarktinstroom van het $H A V O / V W O$ en de diverse opleidingscategorieèn binnen het $M B O$. Ook bij de cijfers in deze tabel dient echter opgemerkt te worden dat de verschillen tussen de onderliggende opleidingstypen (i.e. het lagere aggregatticniveau) erg groot kunnen zijn. De opleidingscategorie 1MBO kandbonten

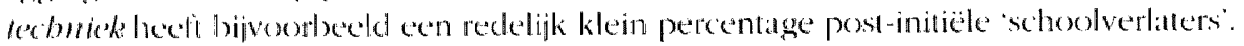
Binnen cle\% opleidingscaltegoric zijn er twee opleidingstypen watar een zeer gron

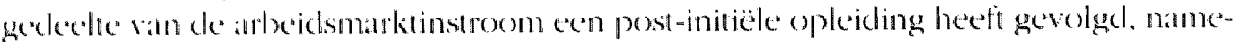

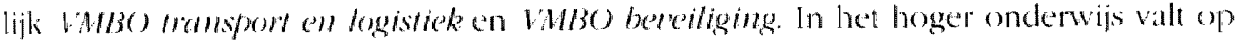
dat $1 / 130$ economice cen hoog percentage arterismarktinstroom van een post-initiëte

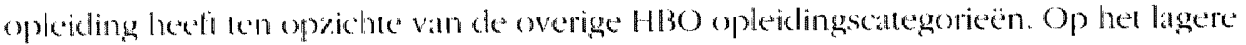

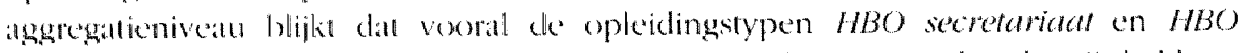

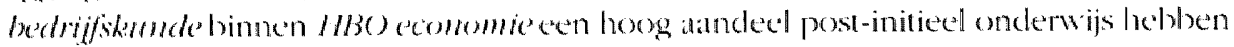

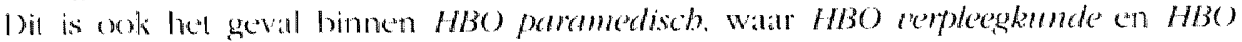

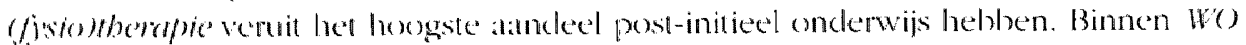

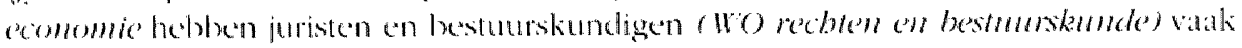

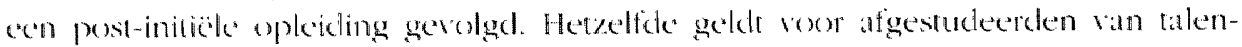

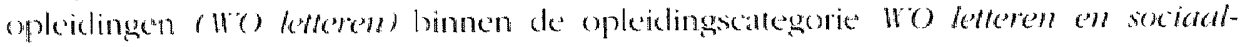
cullurel 


\section{De aansluiting tussen onderwijs en arbeidsmarkt}

In dit boofdstuk wordt een beeld gegeven van de aansiwiting tussen onderwijs en arbeidsmarkt voor schoolverlaters. In paragraaf 3.1 wordt ingegaan op de buidige aansluitingsproblemen per opleidingscategorie. Hierbij uordt in eerste instantie gekseken naar de werkloosbeid. De aansluitingsproblemen kunnen zich ecbter ook op andere manieren uiten ${ }^{3.4}$. Minder zichtbare discrepanties, zoals werk onder bet opleidingsniteau of buiten de eigen vakrichting, kumnen eveneens van belang zijn. In paragraaf 3.2 uorden voor elke opleidingscategorie de toekomstperspectieven tot 2006 van schoolverlaters weergegeven. Hierbij wordt per opleidingscategorie ook ingegaan op bet toekomstperspectief van enkele opmerkelijke onderliggende opleidingstypen. De conjunctunrgevoeligheid van opleidingstypen geeft daabij een breder beeld wan de toekomstige aansluiting tussen opleiding en beroep. In paragraaf 3.3 worden de verwachte knelpurnten in de personeelswoorziening voor werkgevers in beeld gebracht. waarbij tevens aandacht wordt besteed aan de substitutiemogelijkbeden voor wenkesvers tussen personeel met een verschillende opleidingsacblergrond in beroepsgroepen. op deze wijze u'ordt een indruk gegenen wan een risicofactor voor werkgerers ten anzien van de rekrutering wan persomed.

\subsection{Huidige aansluitingsproblemen}

Aansluitingsproblemen tussen het onderwijs en de at teidsmarkt worden veelal beourdeeld door te kijken naar de werkloosheidspercentages onder schoolverlaters me't een bepaalde opleidingsachtergrond. Dit werkloosheidspercentage geeft een indicallie van

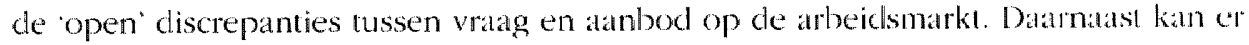
bij de schoolverlaters die wel werk hebben gevonden sprake zijn van 'verborgen' discrepanties. Door het atanbodoverschof kunnen zij genoxlzalkt zijn om werk te aan-

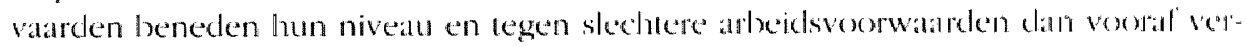
wacht. Schoolverlaters dienen bijvorbectel bij een slechte arleciclsnatrktsituatle vox hun opleiding genoegen te nemen met een tijclelijke in platals van cen vaste atanskelling of met een aanstelling met minder uren dan gewenst (part-lime).

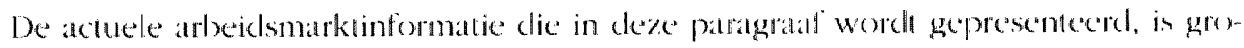

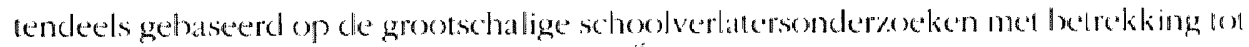

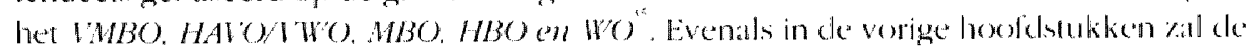

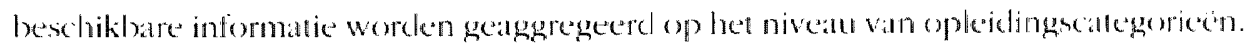

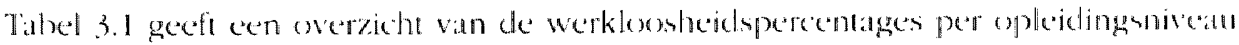

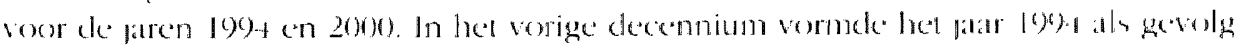

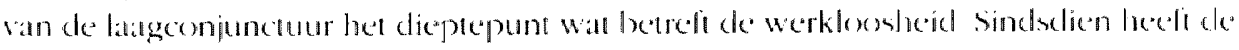

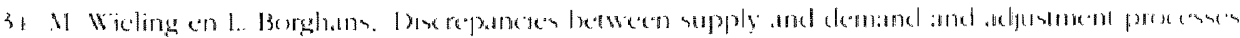

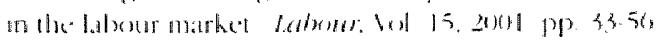

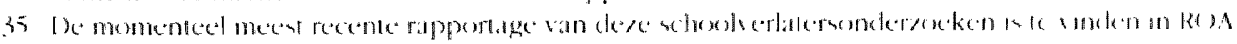

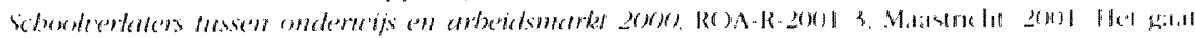

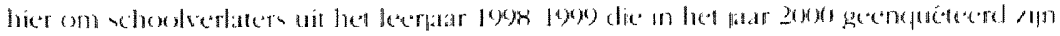


situatie op de arbeidsmarkt zich sterk verbeterd. Uit de tabel blijkt dat de werkloosheid als percentage van de beroepsbevolking is gehalveerd tussen 1994 en 2000 . Voor het basisonderwijs en VMBO tbeorie is de relatieve daling van de werkloosheid iets kleiner dan gemiddeld, in tegenstelling tot het VMBO en het WO. In 2000 was sprake van een zeer krappe arbeidsmarkt, met werkloosheidspercentages die voor het $M B O, H B O$ en WO het niveau van frictiewerkloosheid benaderclen. Dit is de werkloosheid die ontstaat doordat altijd wel een deel van de beroepsbevolking door bijvoorbeeld ontslag of het afsluiten van een opleiding op zoek is naar een baan. Voor werkzoekenden met een algemene opleidingachtergrond (basisonderwijs, VMBO theorie, en HAVO/VWO) is de situatie op de arbeidsmarkt het minst gunstig. Zij hebben de meeste moeite om een baan te vinden.

Tabel 3.1

Werkloosheidspercentage beroepsbevolking naar opleidingsniveau, 1994 en 2000

Basisondewijs
VMBO theorie
VMBO
HNONWO
MBO
HBO
WO
Tolal

1994

$\%$

2000

$\%$

Bron: (BBS(EBB)

Tabel 3.2 latat zien hoe hoog het werkloosheidspercentage onder schoolverlatters wals vor de jaren 1998 en $2000^{*}$. In het algemeen blijk dat zich een verdere verbetering van de werkloosheidssituatie onder schoolverlaters heeft voorgedaan voor schoolverlaters van de opleiding VMBO verzorging is de werkloosheidssituatie a anzienlijk verbeterd. Voor de opleidingscategoriten VMBO landbout en techniek. MBO economie. HBO paramedisch en WO medisch is dere daturentegen enigszins verslechterd, matar blifi zich mot natne vour de schoolverlaters van de latatste drie opleidingscategorieën op een zeer gunstig niveau bevinden. Schoolverlaters van MBO landbontu en techniek. MBO dienstrerlening ("ngezondheidszorg en H") ecomomie hebben cle minste moeite om een bian te vinken. Dadtentegen is de werkloosheid het grootst onder schoolverlaters van

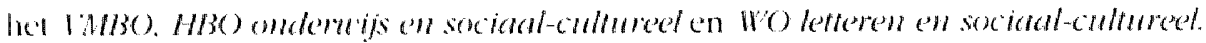

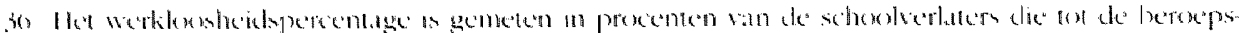

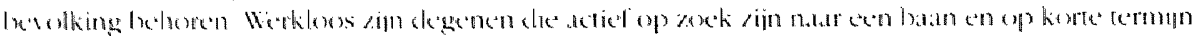

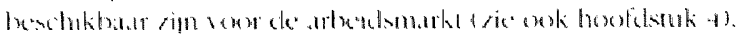


Tabel 3.2

Werkloosheidspercentage schoolverlaters naar opleidingscategorie, 1998 en 2000

Opleidingscategorie

Basisonderwijs

MBBO theorie

VMBO landbouw en techniek

NBBO economie

VMBO verzorging

HAVONWO

MBO landbouw en techniek

MBO economie

MBO dienswerlening en gezondheidszorg

HBO landbouw en techniek

HBO economie

$\mathrm{HBO}$ onderwijs en sociaal-cultureel

HBO paramedisch

Wo landbouw en techniek

Wo economie

Wo letteren en sociaal-cullureel

Wo medisch

Totaal (gemiddeld over alle oplleidingstypen)

Bron: ROA(SIS)

Naast de werkloosheid kan ook de beloning een indicatie zijn voor de aansluiting tussen onderwijs en arbeidsmarkt. Werkgevers die moeite heblen voldoende geschikı personeel te vinden, kunnen proberen hun concurrentiepositie op de arbeidsmarkt te verbeteren door de salarièring natar boven bij te stellen. Tabel 3.3 geeft per opleidingsisec-

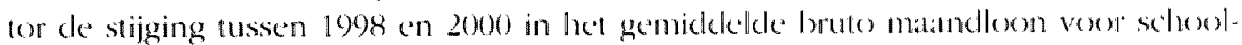
verlaters weer, watabij gecorrigeerd is vour cle inllatic. I te gemidkelde jatalijkse loxnstijging onder schoolverfaters valn $3^{0 \%} 1$ tussen 1998 en $2000 \mathrm{kom}$ goed overeen med de" jaarlijkse stijging van het contractloon van de marktsector in de\%e periocke I te talxel

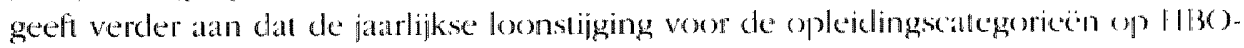
en WO-niveau ongeveer $3 \%$ wats, mel uitzondering valn wo medisc $b$ watr gean lom stijging voor afgestudeerden theeft platsgevonden. Op VMBSO-, HAVO/VW( - en MIBO -

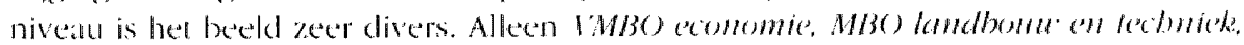
en $M B O$ dienstertening en gezondberdszorg laten een loonsijging zien die lum lowen

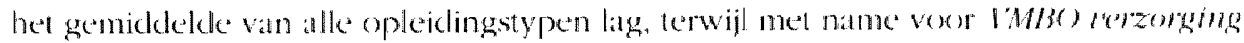
en $M B O$ economie de konstiging laag was.

In figuur 3.1 worden twee verborgen' discrepanties bij cle alanshuiting lussen onderwijs en arbedsmarkt onder schoolverlaters weergegewen. Zij heblxen betrekking op (le. arbeidswoorwataden. met name hel hebben van een part lume diensiverland en een

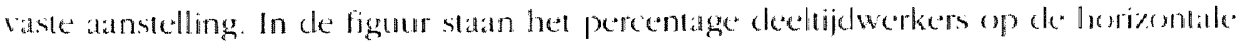
as, en hel percentage flexileck werkers op de verticale as. flet werken in decelijel kan

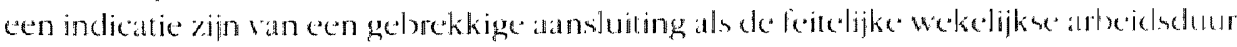
niet orereenkom met de gewenste wekelijkse arbeidadur. I fee percentage schendrer- 
laters met flexibel werk betreft degenen die een tijdelijk contract van korter dan een jaar en geen vooruitzicht op een vast dienstverband hebben, inclusief de schoolverlaters die als uitzend- of oproepkracht werken. Over het algemeen zullen schoolverlaters de zekerheid van een vast dienstverband prefereren boven de onzekerheid van een flexibele aanstelling.

Talbel 3.3

Procentuele gemiddelde jaarlijkse stijging van het gemiddelde bruto maandloon voor schoolverlaters tussen 1998 en 2000 naar opleidingscategorie *

\section{Nr. Opleidingscategorie}

1. Basisonderwijs

2. VMBO theorie

3. VMBO landbouw en techniek

4. WMBO economie

5. VMBO verzorging

6. HANOMWO

7. MBO landbouw en lechniek

8. MBO economie

9. $M B O$ dienstverlening en gezondheidszorg

10. HBO landbouw en techniek

11. HBO economie

12. HBO onderwijs en sociaal-cultureel

13. HBO paramedisch

14. Wo landbouw en tednniek

15. W0 economie

16. Wo letteren en socialal-cultureel

17. W0 medisch

Totual (gemiddeld over alle opleidingstypen)

" Ciecorrigeerd voor inflatie, 1998 is basisijar:

Bron: ROA(SIS)

Fignur 3. I is opgedeeld in vier kwaldranten alan de hand van het gemiddelde percentage scheolverlitters dat in deeltijd werkt of een flexibele atanstelling heeft. De nummers en de hethorende opleidingscategoricën statn in tabel 3.3. In het kwadrant linksonder statan de opleciclingscategoricën watrin relatiel weinig in deeltijl of in een flexibele aanstelling gewerki wordt. Het betreli hier landboure on techniek en economie op MBOen HBO-niveatu. De schoolverlaters van .HBO en HBO landbonu' en techniek en $M B O$

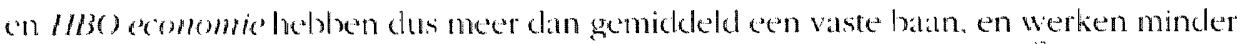

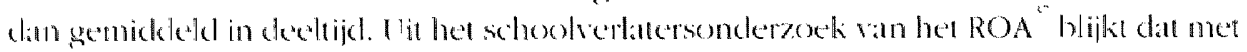

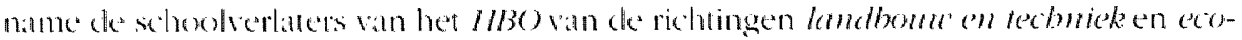

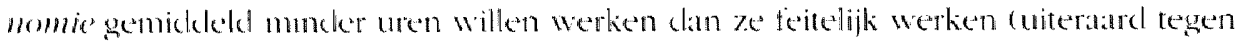
evenredig minder salaris). Dat betekent dat roor deze schoolverlaters de arbeidswoorwatrden vertederen als ze korter en meer in deeleijd kunnen werken

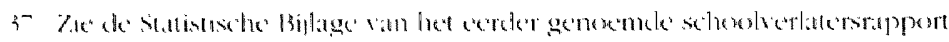


Ook voor de schoolverlaters van WO landbonw en techniek, WO economie en WO medisch in het kwadrant linksboven geldt dat zij gemiddeld minder uren willen werken. In deze opleidingscategorieën komt deeltijdarbeid onder schoolverlaters echter relatief weinig voor. Bovendien hebben schoolverlaters van dleze opleidingscategorieën vaker dan gemiddeld een flexibele in plaats van een vaste aanstelling. Voor de schoolverlaters van WO medisch is het relatief grote aantal flexibele contracten een gevolg van de gebruikelijke tijdelijke arbeidsovereenkomsten na de opleiding tot basisarts, bijvortbeeld in het kader van specialistenopleidingen. In dit geval is er geen duidelijke relatie tussen het percentage werkenden met een flexibele aanstelling en een slechte arbeidsmarktsituatie.

Pigur 3.1

Percentage deeltijdarbeid tegenover percentage flexibel werk onder schoolverlaters, per opleidingscategorie*, 2000

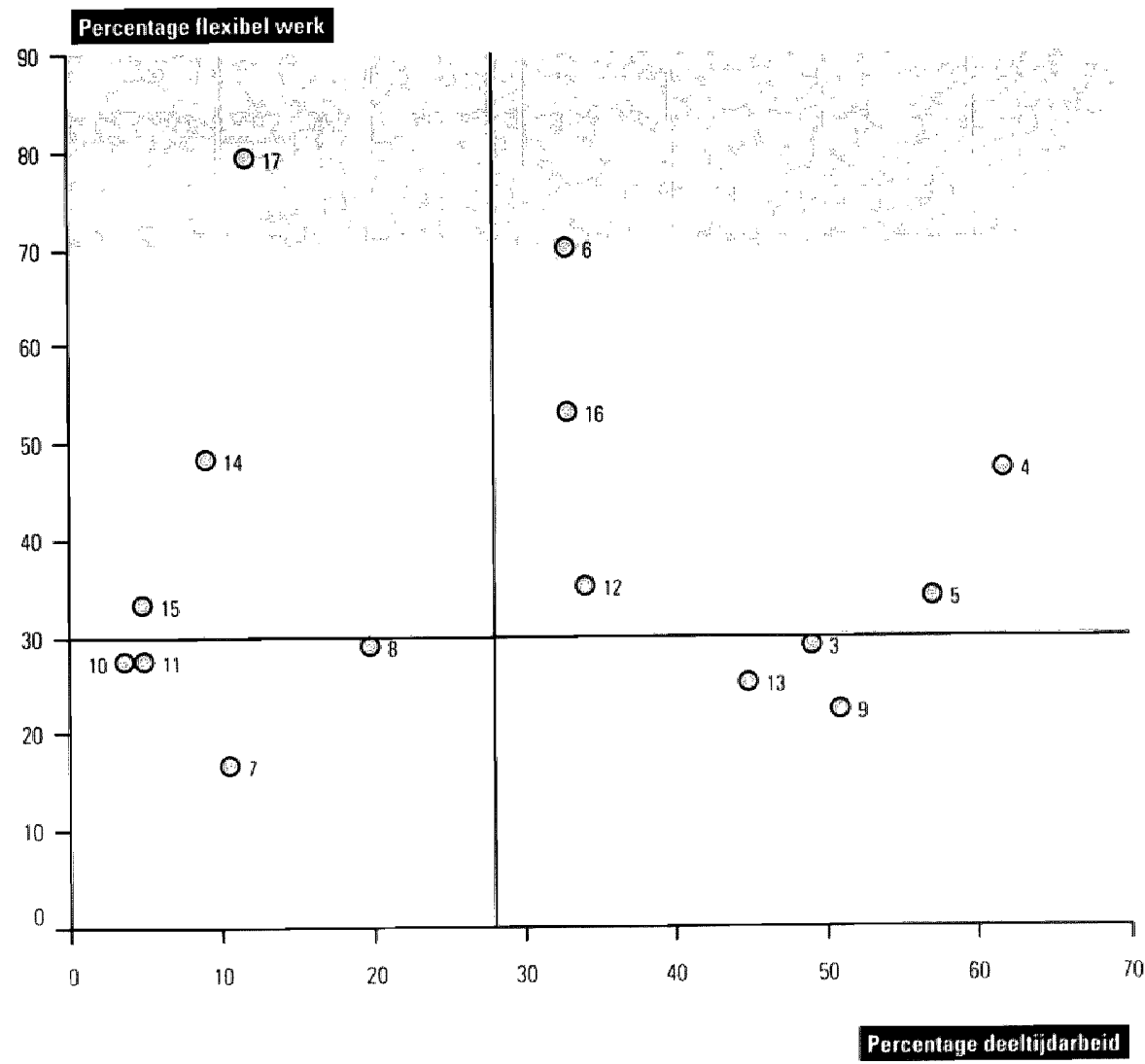

* Zie abel 3.3 vor een owerzicht van de nummers met de betreffende opleidingscategorie. 
De schoolverlaters van VMBO economie, VMBO verzorging, HAVO/VWO en HBO onderwijs en social-cultureet in het kwadrant rechtsboven werken relatief vaak met zowel een flexibele atanstelling als in deeltijd, terwijl ze een vast dienstverband prefereren en, met uitzondering van $H B O$ onderwijs en sociaal-cultureel, juist meer uren willen werken. De arbeidsmarktsituatie is voor de meeste van deze schoolverlaters ten aanzien wan de twee dimensies van figuur 3.1 dus relatief slecht. In het kwadrant rechtsboven is ook de opleidingscategorie WO letteren en saciaal-cultureel opgenomen. De afgesudeerden van deze opleidingscategorie willen vaker dan gemiddeld een kortere werkweek, hetgeen overeenkomt met het relatief hoog percentage van deze opleidingscategorie dat in deeltijd werkt.

De schoolverlaters van VMBO landbouw en techniek in het kwadrant rechtsonder werken relatief vaak in deeltijd, terwijl ze juist over het algemeen een langere werkweek wensen. Aan de andere kant hebluen ze wel vaker dan gemiddeld een vaste aanstelling. Ook de schoolverlaters van MBO dienstverlening en gezondbeidszorg en HBO paramedisch hebben vaker dan gemiddeld een vast dienstverband. Het grote aantal deeltijdwerkers onder de schoolverlaters van VMBO verzorging. MBO dienstuerlening en gezondbeidszorg en HBO paramedisch weerspiegelt het relatief grote aandeel vrouwelijke schoolverlaters in cleze opleidingscategorieën. Toch wensen de schoolverlaters van deze opleidingscategorieèn over het algemeen een langere werkweek.

In figutur 3.2 zijn twee andere dimensies van de aansluiting tussen onderwijs en arbeidsmarkt weergegeven. Hel werkloosheidspercentage onder schoolverlaters op de horizontale as geeft de open discrepanties per opleidingscategorie aan. Het percentage onderbenutting is op de verticale as weergegeven. De onderbenutting van schoolverlatters is een matstaf voor de verborgen discrepanties bij de aansluiting tussen opleiding en beroep. Schoolverlaters kunnen hun risico op werkloosheid verminderen door een baan onder hun opleidingsnivealu te alanvaarden. De kans op onderbenutting binnen cen opleidingscategorie zou derhalve hoger kunnen worden bij een slechtere arbeidsmatktsiltatlice. In dat geval is ar sprake van een trade off tussen werkloosheid en onderlentuing. A:In de andere kant is hel ook mogelijk dal een slechtere arbeidsntaktsiluatie \#) de werkloosheid als de onderlenutting vergrool.

lighur 3.2 is eveneens opgedeceld in vier kwadranten door twee lijnen, een verticale lijn dic hel gemideledele werkloosheidspercentage, en een horizontale lijn die het gemid-

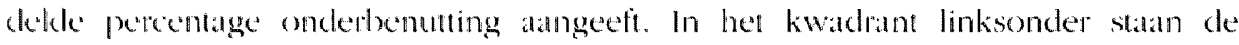

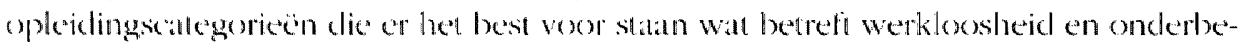
nutuing. De schoolverlaters van de opleidingscategorieën MBO diensterlening en gezondbeidszorg. HIBO landbonu en fechniek en WO medisch worden weinig met werkloosheid gecontionterd, terwijl ze ower thet algeneen nawwelijks banen onder hun oplerellingsniveau hoeven te accepteren. In het kwadrant rechtshoven statan datarcontegen de oplevidingscantegorieën die een bovengemuldekle werkloosheid en onder-

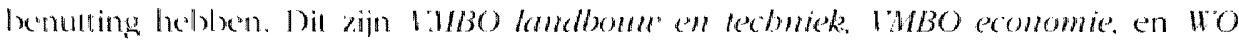

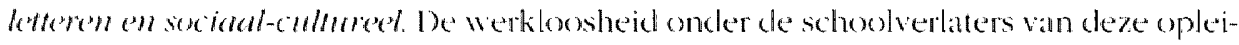
dingscategorieżen zou hoger zijn witgevallen als ze niet waren witgeweken nar banen

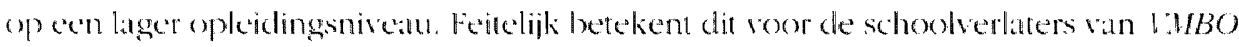

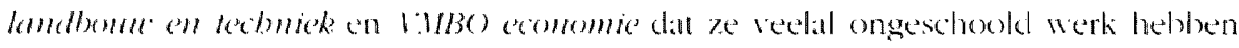

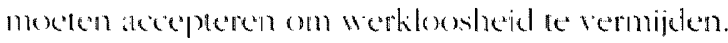


Van de opleidingscategorieën in de kwadranten linksboven en rechtsonder kan gezegd worden dat er sprake is van een 'trade off'. In het vak linksboven valt op dat de onderbenutting met name hoog is onder schoolverlaters van de opleidingscategorie MBO landbouw en tecbniek, terwijl de werkloosheid onder deze schoolverlaters erg laag is. Voor deze schoolverlaters, maar ook voor de schoolverlaters van de opleidingscategorieën WO economie en WO landbouw en techniek geeft het relatief lage werkloosheidspercentage een te rooskleurig beeld van de arbeidsmarktsituatie. Veel van deze schoolverlaters wijken immers uit naar een baan op een lager opleidingsniveau. In hel vak rechtsonder is de onderbenutting onder schoolverlaters van de opleidingscalcgorieën VMBO verzorging. HBO onderwijs en sociaal-cultureel en HBO paramedisch relatief laag, terwijl de werklloosheid boven het gemiddelde ligt. Dit kan verklaard worden doordat schoolverlaters met een leraren- of zorgopleiding weinig uirwijkmogelijkheden buiten het onderwijs of de zorgsector hebben, en daardoor ook moeilijk werk onder hun niveau vinden.

Figuur 3.2

Werkloosheidspercentage tegenover percentage onderbenutting onder schoolverlaters, per opleidingscategorie*, 2000

Percentage onderhenutting

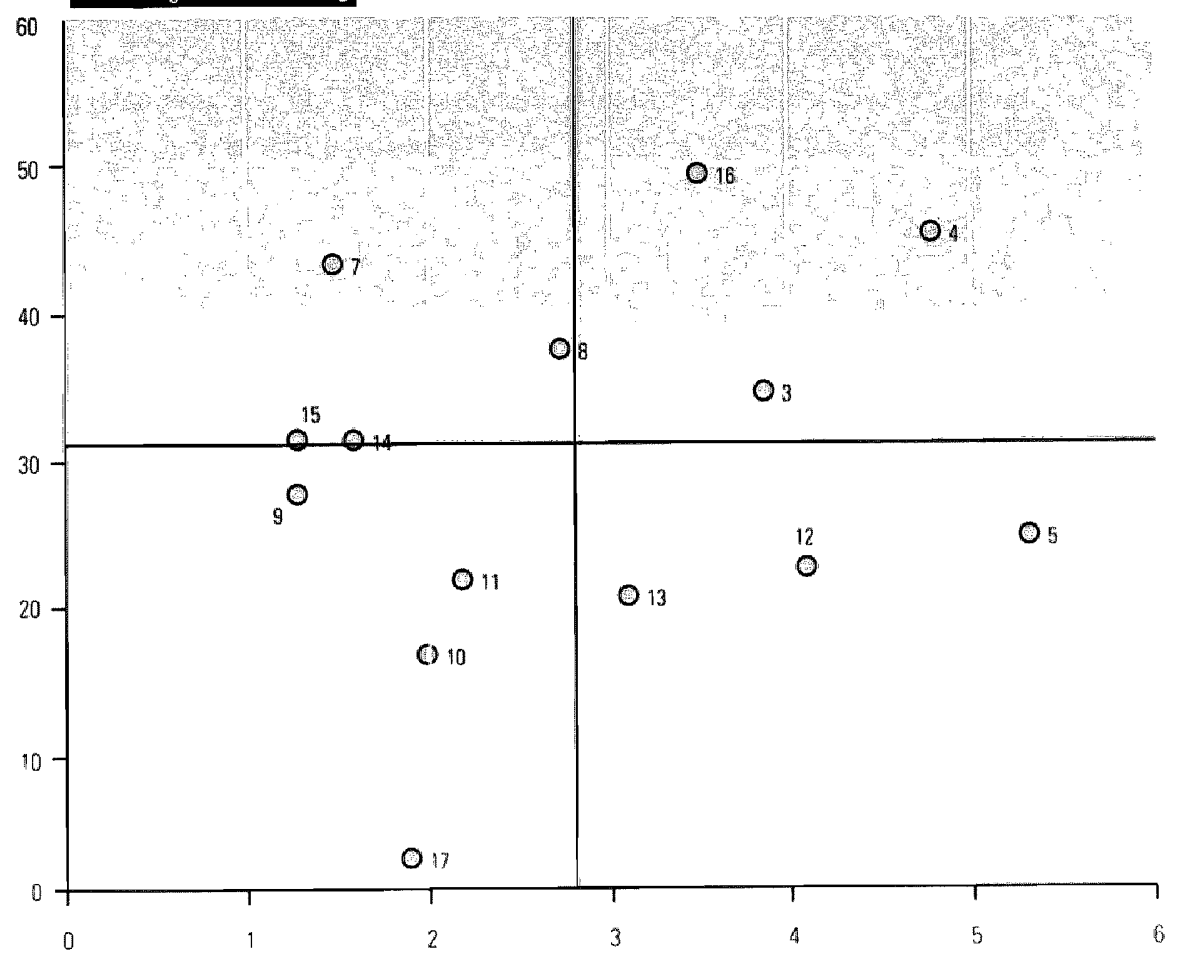

\footnotetext{
* Zie tabel 3 i voor een overziclnt van de nummers met de betreflende oplendingscategonie.
} 
Figuur 3.3 geeft de relatie weer tussen de verborgen discrepanties bij de aansluiting russen onderwijs en arbeidsmarkt, namelijk onderbenutting en werken buiten de vakrichting. In cle figuur wordt per opleidingscategorie het percentage onderbenutting onder schoolverlaters op de horizontale as afgezet tegen het percentage schoolverlaters werkzaam buiten de eigen vakrichting op de verticale as. Een gebrekkige aansluiting tussen onderwijs en arbeidsmarkt kan zich op één van beide. of beide dimensies uiten. De figuur is wederom onderverdeeld in vier kwadranten aan de hand van de gemiddeldes op beide dimensies.

\section{Jiguur 3.3}

Percentage onderbenutting tegenover werk buiten eigen vakrichting onder schoolverlaters, per opleidingscategorie*, 2000

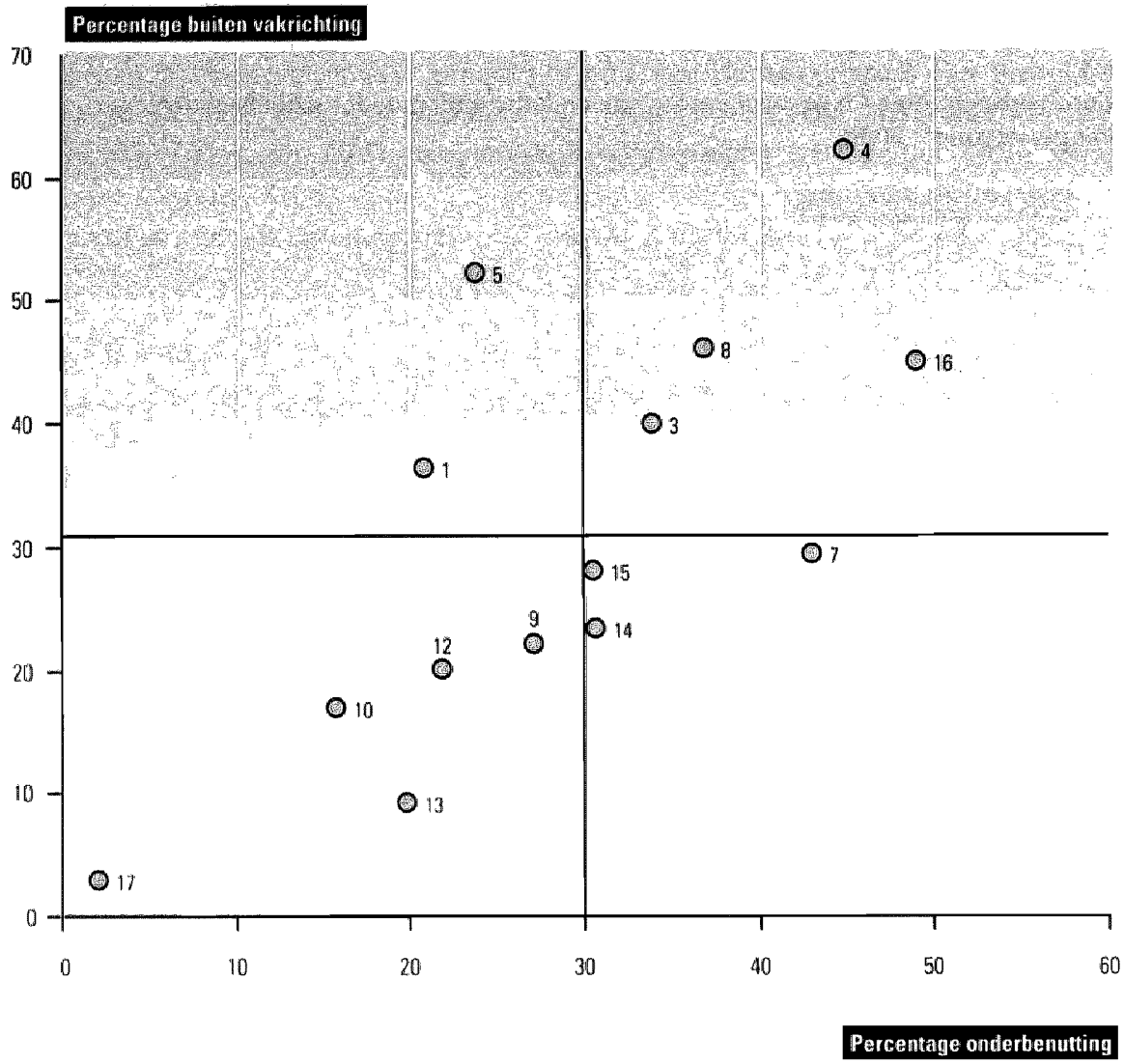

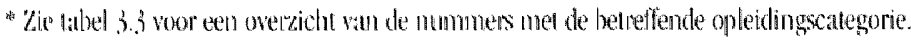

Bron. RoAtSis) 
In het kwadrant linksonder bevinden zich de opleidingscategorieèn MBO diensterenning en gezondbeidszorg, HBO landboww en techniek, HBO onderwijs en sociaal-cultureel, $H B O$ paramedisch en WO medisch, waarvan de schoolverlaters relatiel weinig onder hun niveau of buiten hun vakrichting werken. Deze schoolverlaters hebben op deze twee dimensies een relatief goede atansluiting tussen de gevolgde opleiding en het beroep waarin ze werkzaam zijn. Uit figuur 3.1 is gebleken dat de schoolverlaters van deze opleidingscategorieën, met uitzondering van $H B O$ onderuis en sociaal-cullured en WO medisch, tevens relatief vaak een vaste in plaats van een flexibele aansitelling hebben. Uit figuur 3.2 is bovendien gebleken dat er onder de schoolverlaters van $M B O$ dienstverlening en gezondbeidszorg. HBO landbouu en techniek en WO medisch weinig werkloosheid is. De schoolverlaters van deze opleidingscategorieën helben, mede door het vakspecifieke karakter van hun opleiding, een sterke positie op de arbeiclsmarkı. Dit in tegenstelling tot de werkloosheid onder schoolverlater's van HBO onderuijs en sociaal-culturee en HBO paramedisch. Voor deze schoolverlaters met een opleiding gericht op het onderwijs en de zorgsector is al opgemerkt dat ze weinig uitwijkmogelijkheden hebben, niet alleen onder hun niveau mar ook buiren hun vakrichting zoals uit figuur 3.3 blijkt. Hierdoor vertaalt een relatief slechte situatie op cke arbeidsmarkt voor deze opleidingen zich vooral in een hogere werkloosheid

Uit figuur 3.3 blijkt verder dat met name schoolverlaters van de VMBO-richtingen buiten hun vakrichting werkzaam zijn. Voor VMBO landbotu' en techmick en VMBO aconomie komt daar nog bij dat de schoolverlaters van deze richtingen relitiel vaak onderbenut worden, hetgeen in veel gevallen wil zeggen dat zij ongeschoold werk verrichten. De arbeidsmarktsituatie van schoolverlaters van de drie VMBO-richtingen is, mede gezien de relatief hoge werkloosheid, duidelijk slechter dan voor de hogere opledingsniveaus. Voorts zijn ook schoolverlaters van MBO economie en WO lefleren en sociaal-cullureel relatief valak zowel onder hun niveau als buiten hun vakrichting werkzaam. De arbeidsmarktpositie van deze schoolverlaters is zwak. Schoolverlatters vam WO ketteren en sociad-cultwred zijn lowvendien vaker dan gemiddeld werkloos en heh-

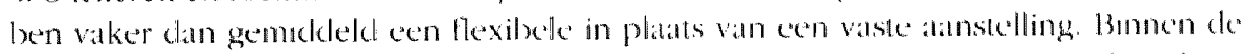

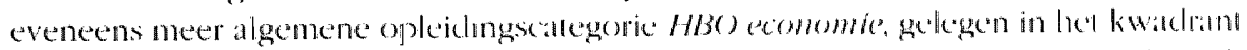
rechtsboven, is het pereentage schosplverlaters dat buten de valkridating wertat ook

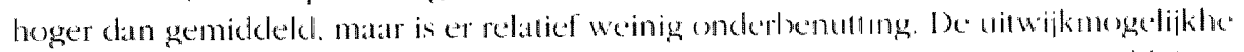
den voor deze schoolverlaters zijn wataschipnlijk voldoencle, wardoor te cen kleinere kans op werkloosheid en een gretere kins op een vaste balan lwbben

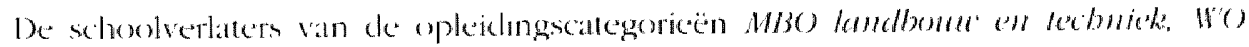

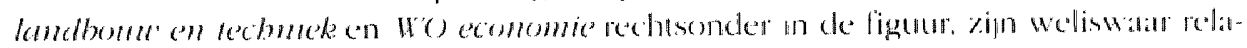

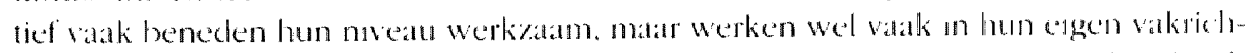

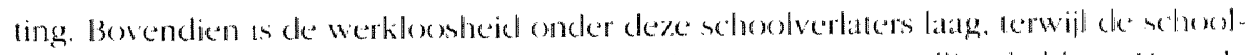

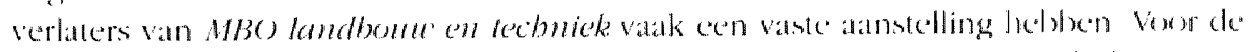

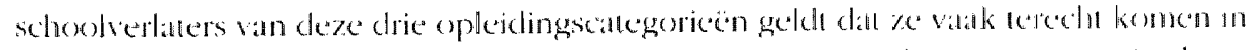
functies in hun ejgen vakrichting. en dal re vanuit een wat lagere statrpostice dengroesen natar een hoger functienivedu.

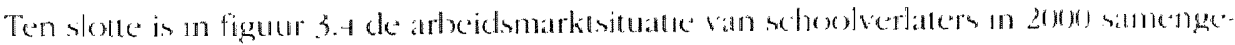

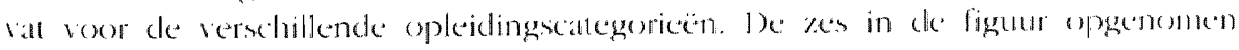


dimensies van de ansluiting tussen onderwijs en arbeidsmarkt zijn eerder in deze paragraaf al bij de afzonderlijke tabellen en figuren besproken.

Figutur 3.4

De arbeidsmarktsituatie van schoolverlaters in 2000 naar zes dimensies per opleidingscategorie*

Werkloosheid Loonstijging Onder- Buiten- Flexibel Deeltijd-
benutting vakrichting werk arbeid

Basisonderwijs

WMBO theorie

WMBO landbouw

en techniek

VMBO economie

VMBO verzorging

HAVONWO

$M B O$ landbouw en techniek

MBO economie

$\mathrm{MBO}$ dienstverlening en

gezondlheidszorg

HBO landbouw en techniek

HBO economie

benutting vakrichtin

werlk arbeid

HBO onderwi|s en

sociaal-cullureel

HBO paramedisch

Wo landbouw en techniek

Wo economie

wo letteren en

socital-cultureel

wo medisch

$\begin{array}{cccccc}+ & 0 & 0 & 0 & 0 & + \\ + & + & + & + & 0 & + \\ + & - & 0 & + & 0 & + \\ - & 0 & & + & + & 0 \\ 0 & + & + & 0 & - & 0 \\ - & + & 0 & 0 & - & + \\ 0 & - & - & - & - & - \\ 0 & 0 & - & 0 & - & - \\ + & + & 0 & - & 0 & 0 \\ 0 & 0 & - & - & - & 0 \\ - & 0 & 0 & 0 & + & - \\ - & 0 & 0 & 0 & 0 & - \\ & 0 & + & 0 & + & 0 \\ 0 & - & - & - & + & 0\end{array}$

* Zie voor de delinitie van de verschillende dimensies de uitleg bij de tabellen en figuren in deze paragraaf. Op elke dimen-

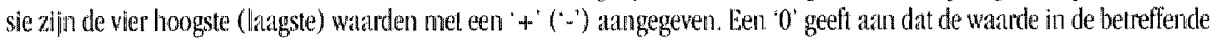
opleidingscategorie rondom de mediane watude ligt. Bij een onbekende warde is er geen teken weergegeven.

Bron: RON(SIS)

\subsection{Toekomstige arbeidsmarktperspectieven en knelpunten in de personeelsvoorziening naar opleiding}

Perspectieven en knelpunten naar opleidingscategorie

Op basis valn de in hoofstuk 2 belichte valag- en anbolontwikkelingen en de darat vortvlosiende sulostitutieprocessen op de arbeidsmarkt kan een indicatie worden gegeven ran de verwachte arleedsmarktperspectieven voor nieuwhomers op de

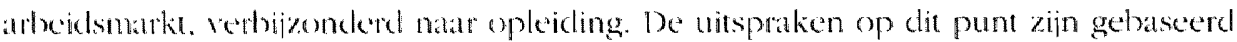
op de medicator Toekomstige Arbejdsmarktperspectieren (ITA), die voor elk opleidings-

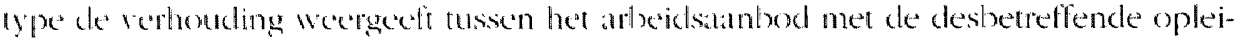

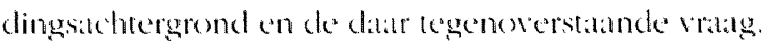

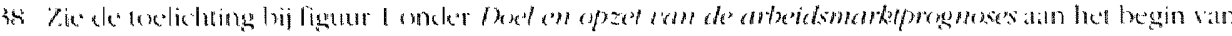
leve rapport 
Als het arbeidsaanbod kleiner is dan de vraag, en de ITA dus kleiner dan of gelijk is wan 1,00, wordt het arbeidsmarktperspectief als goed of zeer goed getypeerd. Schoolverlaters zullen dan naar verwachting betrekkelijk gemakkelijk een baan vinden op een functieniveau en in een -richting waarop men toen men aan de opleiding begon zou mogen rekenen. In het geval van een grote ITA zullen schoolverlaters natar verwachting veel moeite hebben een baan te vinden op een functieniveau en in een richting waarop gerekend mocht worden toen men aan de opleiding begon. Schoolverlaters van het betreffende opleidingstype worden gedwongen een baan in een andere ricliting of beneden hun niveau te accepteren, tegen minder goede arbeidsvoorwaarden te werken, meer en langer tijdelijk werk te accepteren of zullen zelfs werkloos worden. Dit betekent voor schoolverlaters van dit opleidingstype dat de atansluiting tussen opleiding en beroep zal verslechteren.

Wanneer een bepaalde opleiding een goed of zeer goed arbeidsmarktperspectief bredt. dan zal het voor de schoolverlaters met deze opleidingsatchtergrond betrekkelijk gemakkelijk zijn om een goed op de opleiding aansluitende baan te vinclen Daarentegen zal het voor werkgevers juist moeilijk zijn om schoolverlaters met de $z^{*}$ opleidingsachtergrond an te trekken. Een goed arbeidsmarktperspectief voor schoolverlaters zal immers doorgaans samenvallen met grote knelpunten in de personectsvoorziening voor werkgevers.

Om de verwachte toekomstige wervingsproblemen met betrekking tor de verschillende opleidingstypen in beeld te kunnen brengen, is een Indicator Toekomstige Knolpumen in de Personeelsvoorziening (ITKP) ontwikkeld. Zoals in Doel en opzer lan de abeidsmarktprognoses reeds werd aangegeven wijkt deze inclicator alleen van de ITA all bij de opleidingstypen die te kampen hebben met krimpende werkgelegenheid. In dial gevill zullen bedrijven immers, wanneer er sprake is van knelpunten, de mogelijkheid atngrijpen om de gedwongen uitstroom van het zittende personeel af te remmen, walirdoor de vereiste instroom van nieuwkomers lager wordt. Als de ITKP klenner dan of gelijk is aan 1,00 worden de verwadhte knelpunten in de personeelsvoorzienung als groot getypeerd is de lTKP kilerner dan of gelijk atan (1,85. dan wordi zellis gesproken over 'zeer grote' kansen op knelpunten in de personectsvoorziening.

Zoals eerder aangegeven, worden de vraig- en aantoxdontwikkelingen werergegeven op het aggregatieniveau van 17 oplendingscategorieèn, welke 104 onderliggende opler. dingstypen behelzen". Het arbedsmatktperspectef van een onderliggend opledelings-

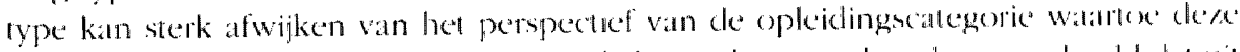
behoort Hierbif zal worden ungegatan na de bespreking van het algemene beckl dial uil

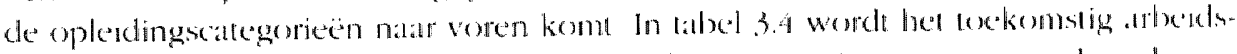
markiperspectief van schoolverlaters per opleidingscalegorie weergegeven dor de exer

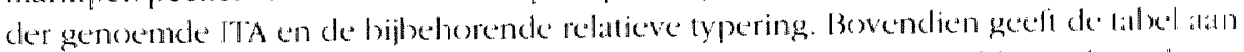

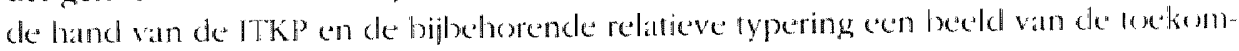
stige knelpunten in the personecelsworziening per oplesidingscallegerie.

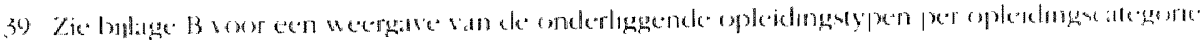


Het blijkt dat het toekomstig arbeidsmarktperspectief redelijk is voor de schoolverlaters die basisonderwijs als hoogst voltooide opleiding hebben afgesloten (voor een belangrijk deel "drop outs" van het VMBO). Het is opmerkelijk dat de schoolverlaters die als ongeschoold kunnen worden beschouwd een redelijk arbeidsmarktperspectief hebben, vooral gezien de doorgaans matige of zelfs slechte perspectieven van de schoolverlaters van het $V M B O$. In hoofdstuk 1 is reeds aangegeven dat dit verklaard kan worden uit de hoge vervangingsvratag voor basisonderwijs ten gevolge van het alsnog afronden van een vervolgopleiding door werkenden met deze opleidingsachtergrond. Dit doorleereffect is (veel) minder groot voor de vier opleidingscategorieën op VMBO-niveau. Hierdoor valt de verwangingsvraag bij deze categorie minder hoog uit dan bij basisonderwijs, en is het toekomstig arbeidsmarktperspectief navenant slechter voor de schoolverlaters van het VMBO. Daarbij steekt het slechte arbeidsmarktperspectief voor VMBO economie extra ongunstig af als gevolg van de erg hoge arbeidsmarktinstroom van schoolverlaters met deze opleidingsachtergrond.

Uit cle ITKP blijkt echter dat werkgevers geen knelpunten in de personeelsvoorziening ondervinden voor schoolverlaters met basisonderwijs. Ook hierop is in hoofdstuk 1 al ingegaan door te wijzen op de relatief grote uitstroom van werkenden met basisonderwijs, waardoor werkgevers in hun vraag naar ongeschoold personeel kunnen voorzien door de uitstroom af te remmen. Deze hoge uitstroom, die zich niet vertaalt in vervangingsvraag maar in een krimpende werkgelegenheid (negatieve uitbreidingsvraag), speelt ook een rol bij de drie beroepsgerichte opleidingscategorieën van het VMBO. Dit is in tabel 3.4 af te lezen uit cle grotere waarcle voor de ITKP dan voor de ITA.

Op het HAVO/NWO/MBO-niveau valt op dau de schoolverlaters van de algemene opleiding HAVO/VWO een matig perspectief hebben, terwijl de schoolverlaters van de drie onderscheiclen opleidingscategorieèn van het $M B O$ in het algemeen een goed perspectief hebben. Dit verschil tussen HAVO/VWO en $M B O$ is voor een grool deel toe te schrijven aan de verwachte erg hoge arbeidsmarktinstroom van schoolverlaters van het HAVO $/ W O$, die de eveneens hoge uitbreidings- en vervangingsvrag natr deze schoolverlaters rumschoots overtreft. Voor MBO landbotra' en techniek. MBO economic. an MBO dienstrerlening en gezondbeidszorg geld dall de instrom iets lager en de uithreidings- en vervangingsvatag iets hoger dan het landelijke gemidkelde liggen. Bij gevolg zijn de knelpunten voor werkgevers bij het atntrekken van MBO-personeel in hel algemeen groos, terwijl er vrijwel geen knelpunten zijn bij het alantrekken van algemeen opgeleid personcel op HAVO/VWO-niveatu. 
Tabel 3.4

Indicator toekomstige arbeidsmarktperspectieven (ITA) en Indicator toekomstige knelpunten in de personeelsvoorziening naar opleidingscategorie (ITKP)

\section{Opleidingscategorie}

Basisonderwijs

WMBO theorie

WBO landbouw en techniek

VMBO economie

IMBO verzorging

HAVONWO

MBO landbouw en techniek

MBO economie

MBO dienstverlening en gezondheidszorg

HBO landbouw en techniek

$\mathrm{HBO}$ economie

HBO onderwijs en socinal-cultureel

HBO paramedisch

Wo landbouw en techniek

wo economie

Wo letteren en sociaal-cultureel

WO medisch
ITA

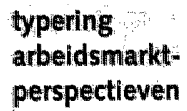

1,01

1,07

1,11

1,18

1,11

1,11

0,99

0,98

1,00

0,89

0,96

0,90

0,88

0,85

0,82

0,87

0,97

redelijk
matig
matig
slechi
matig
matig
goed
goed
goed
goed
goed
goed
goed
zeer goed
zeer goed
goed
goed

ITKP

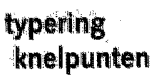

1,21

1,07

1,25

1,24

1.19

1,11

0,99

0,98

1,00

0,89

0,96

0,90

0,88

0,85

0,82

0,87

0.97 geen vrijwel geen

geen

geen

geen

vijiwel geen

groot

groot

groot

grool

grool

groot

groot

zeer groot

zeer grool

grool

grool

Bron: ROA(POA)

Evenals voor het $M B O$ zijn de verwachte arbeidsmarktperspectieven ook gunstig voor de schoolverlaters van alle opleidingscategorieën van het $H B O$ en het WO. Een lxdangrijke reden hiervoor is dat de werkgelegenheid voor deze opleidingscategorieën natur verwachting meer dan gemiddeld zal groeien, met uitzondering van WO medisch, lerwijl de groei van de instroom, met uitzondering van HBO economie en WO economie, duidelijk achterblijf bij de gemiddelde landelijke groei. Hoewel ook de vervangings-

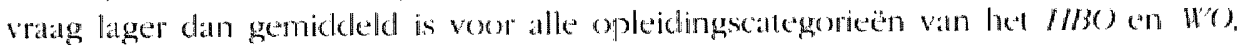

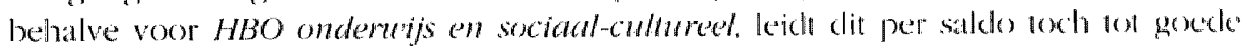
perspectieven voor schoolverlaters van het hoger onderwijs. Werkgevers blijven derhalve geconfronteerd worden met grote kneelpunten op de arlecidsmarkt bij het atantrekken van hoger opgeleid personeel. Vanwege een lage arbaklsmarktinstrom van WO landbotu' en techmiek en een erg hoge uitbreiclingsvrang voor Wo economic, worden voor deze twee opled dingscategorieën zelfs zeer goede arbeidsmarktperspecticven verwacht voor schoolverlaters en zeer grote knelpunten in de personcelsvostziening Overigens is zowel de lage uithreidongsvratag als de lage arbeidsmarktonstrom vour W'O medisch opmerkelijk. I)e knelpunten in de personed svoorziening voor howg opgeleid medisch personeel kunnen edhter nog groter worden als de arbeidsmatklinstrom van schoolverlaters van medische" opleidingen geen gelijke tred houd mel een mogeslijke toename van de uibreiclingsvatag door extrat uitgaven aan de zorgscetor.

Het algemene beekl van het toekomstperspectief van schoolverlaters is clat de tweede-

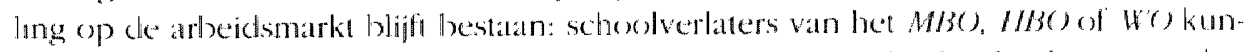
nen in grote liphen rekenen op goede perspectieven. terwijl thoolverlaters van heat 
VMBO of het HAVO/VWO aanzienlijk minder goede perspectieven hebben Een nog scherpere tweedeling doet zich voor ten aanzien van de knelpunten in de personeelsvoorziening voor werkgevers: deze zullen groot tot zeer groot zijn voor personeel met een MBO-, HBO-, WO-opleiding, terwijl er (vrijwel) geen knelpunten verwacht worden voor ongeschoold personeel en mensen met een VMBO- of HAVO/VWO-opleiding.

\section{Verdeling van schoolverlaters naar toekomstperspectief en knelpunten}

Zoals eerder opgemerkt kunnen de toekomstige arbeidsmarktperspectieven van verschillende opleidingstypen binnen eenzelfde opleidingscategorie van elkaar verschillen. In tabel $3.5 \mathrm{komt}$ dit tot uiting in de verdeling van het percentage schoolverlaters naar toekomstig arbeidsmarktperspectief binnen een opleidingscategorie. De verwachte arbeidsmarktperspectieven voor schoolverlaters in 2006 laten in her algemeen een positief beeld zien. Hoewel van de 104 onderscheiden opleidingstypen (zie bijlage B) voor 21 opleidingstypen een slecht of matig en voor 66 opleidingstypen een goed of zeer goed arbeidsmarktperspectief wordt verwacht, geeft een verdeling van het toekomstperspectief naar het percentage schoolverlaters een minder positief beeld.

Uit tabel 3.5 blijkt dat ongeveer $40 \%$ van het total aantal schoolverlaters een (zeer) goed perspectief heeft, maar clat het percentage schoolverlaters met een slecht of matig perspectief bijna even groot is. Voor cle viffaarsperiode van 2001 tot 2006 betekent dit dal 125.000 van de ca. 340.000 schoolverlaters die jaarlijks instromen op de arbeidsmarkt, een ongunstig arbeidsmarktperspectief hebben. Het zijn voornamelijk schoolverlaters van het $V M B O$ en het HAVO/VWO die met de gevolgen hiervan, zoals werkloosheid, slechtere arbeidsvoorwatarden en werk onder het opleidingsniveau, worden geconfronteerd. Toch zijn de toekomstige arbeidsmarktperspectieven voor schoolverlaters van sommige opleidlingstypen op VMBO-niveau gunstig. zoals bijvoorbeeld voor VMBO beveiliging. Voor schoolverlaters van dit opleidingstype wordt zalls een goed arbeidsmarkiperspectief verwacht.

Ook will tahel 3.5 blijkt dalt de perspectieven voor schoolverlaters van het MB3O met name goed zijn voor de richtingen MBO kandbonu' en techniek en MBO economie. Voor selhoolverlaters van deze twee opleidingstichtingen zijn de perspectieven alleen slecht of mallig als zij een opleiding in MBO milien en growe mime, MBO grafiscbe techniek.

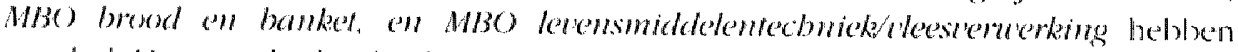
gevolgd. Hel atantal sichoolverlaters mot een ongunstig arbeidsmarktperspectief binnen

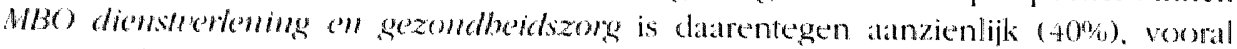
vamwege hed relatief grote antal schoolverlaters van MBO sociad-caltured en $M B O$ miterlijke revzonging, watuvoor een matig perspectief geldt. Datarentegen heeft

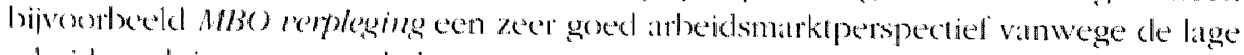
arbeidsmarlitinstroom en de hoge vervangingsvatag.

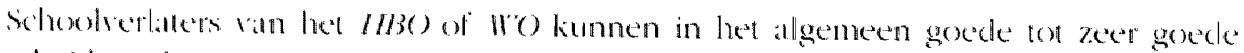

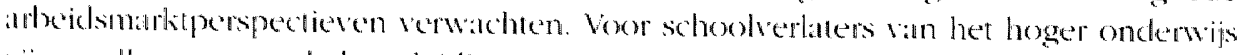
zijin er alleen voor enkele opleidingstypen ran het HBO slechte of matige voonditzichw'n. Binnen de opleidingscategorie HBO ecomomie is het sleche artbeids-

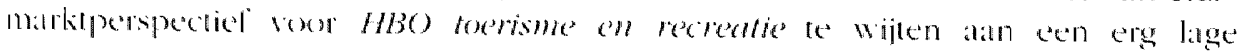


vervangingsvraag en een erg hoge arbeidsmarktinstroom van het niet-reguliere onderwijs. Verder zijn de arbeidsmarktperspectieven voor schoolverlaters van $H B O$ communicatie en journalistiek en $H B O$ personeel en arbeid. beide binnen de opleidingscategorie HBO sociaal-culhureel, matig.

Tabel 3.5

Percentage schoolverlaters naar verwacht arbeidsmarktperspectief in 2006, per opleidingscategorie

Opleidingscategorie

Basisonderwijs

MMBO theorie

VMBO landbouw en techniek

MMBO economie

$M M B O$ verzorging

HAVONWO

MBO landbouw en techniek

MBO economie

MBO diensiverlening en gezondheidszorg

$\mathrm{HBO}$ landbouw en techniek

$H B O$ economie

$H B O$ onderwijs en sociaal-cultureel

HBO paramedisch

Wo landbouw en techniek

Wo economie

Wo letteren en sociaal-cultureel

Wo medisch

Totaal

Bron: ROA(POA)

\section{slecht of matig \\ perspectief$$
\%
$$

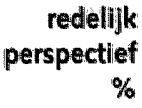

$\%$

100

100

75

75

100

100

14

0

40

0

9

15

0

0

0

0

0

37
0

$20 \quad 5$

250

$0 \quad 0$

$0 \quad 0$

$13 \quad 73$

$39 \quad 61$

$33 \quad 28$

$10 \quad 90$

$35 \quad 56$

$0 \quad 85$

$0 \quad 100$

$0 \quad 100$

$0 \quad 100$

$4 \quad 96$

$13 \quad 87$

22

4

Het spiegelbeeld van de arbeidsmarktperspectieven voor schoolverlaters zijn de lox"komstige knelpunten in de personeelsvoorziening voor werkgevers, welke in lalot 3.6 worden weergegeven. Ook hier komt de eerder genomele tweedeling van de: arbeidsmarkt duidelijk natar voren: er zijn vrijwel alleen grote tot zeer grote knelpunten in de personeelsvoorziening voor MBO'ers, HBO'ers en WO'ers. Deze knelpunten lacesben betrekken op $40 \%$ van de schoolverlaters, terwijl voor matr liefst de helft van de schoolverlaters geen knelpunten op de arbeidsmarkt bestaan. De matschappelijke baten van de publieke investeringen in het onderwijs van de iweede groep schoolverlaters die met name alkomstig zijn van het basisonderwijs, VMBO en HAVO/LWO zulken in eerste instantie relatief klein zijn, zeker in het licht van de alanhouklende groste krapte op de arbeidsmarki" Opvallend is verder nog de opleidingscategorice Mlso dienstertening en gezondbeidszorg. watrbinnen voor MBO sociaal-culthred. Allso) terzorging. MBO witerlijke berzorging en MBO beueging en therafie vrijwel geen

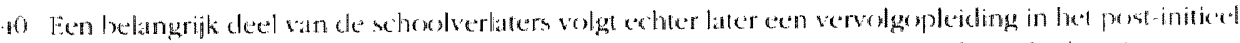

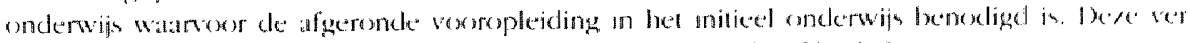

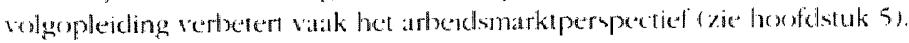


knelpunten in de personeelsvoorziening worden verwacht. Deze opleidingstypen nemen bijna $70 \%$ van de arbeidsmarktinstroom van $M B O$ dienstverlening en gezondbeidszorg voor hun rekening.

Percentage schoolverlaters maar verwachte knelpunten in de personeelsvoorziening in 2006 .

\author{
Tabel 3.6 \\ per opleidingscategorie

\section{Opleldingscategorie}

Basisonderwijs
WMBO theorie
WMBO landbouw en techniek
WMBO economie
WMBO verzorging
HAVO/WWo
MBO landbouw en techniek
MBO economie
MBO dienstverlening en gezondheidszorg
HBO landbouw en techniek
HBO economie
HBO onderwijs en sociaal-cultureel
HBO paranedisch
WO landbouw en techniek
WO economie
WO letteren en social-cultureel
WO medisch
Totaal \\ Basisonderwifs \\ VMBO landlbouw en techniek \\ VMBO economie \\ VMBO verzorging \\ HAVO/WWO \\ MB30 dienstverlening en gezondheidszorg \\ HBO landbouw en techniek \\ HBO economie \\ HBO onderwi|s en sociant-culuree \\ HBO paramedisch \\ o land bouw en techmiek
}

Bron: ROA(POA)

\author{
(vrijwel) geen \\ knelpunten
}

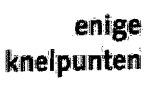

(zeer) grote

knelpunten

$\begin{array}{rrr}100 & 0 & 0 \\ 100 & 0 & 0 \\ 95 & 0 & 5 \\ 100 & 0 & 0 \\ 100 & 0 & 0 \\ 100 & 0 & 0 \\ 14 & 13 & 73 \\ 0 & 39 & 61 \\ 69 & 6 & 25 \\ 0 & 10 & 90 \\ 9 & 35 & 56 \\ 15 & 2 & 83 \\ 0 & 0 & 100 \\ 0 & 0 & 100 \\ 0 & 0 & 100 \\ 0 & 4 & 96 \\ 0 & 13 & 87 \\ & & \\ 50 & & \end{array}$

Toekomstig arbeidsmarktperspectief en conjunctuurgevoeligheid

Om een beter becld te kunnen krijgen van de mogelijke kwetshatheid van de verschillende opleidingscalegorieèn, word hier ingegatan op de conjuncturgevoeligheid van die werkgelegenheid. Dil structureel kenmerk van de arbeidsmarktpositie van een opleidingstype geefi een indicatic van de arbeidsmarkirisicos die de keuze voor een bepaalde opleiding met zich meebrengl. Het arbeidsmarktrisico van een bepaalde opleidingske:uze kom tot uiting in de matle watarin de werkgelegenheid voor de desilestreftende opleidingsachtergrond onderhevig is atn conjuncturele fluctuaties. Wamneer or sterke schommelingen optreden in de werkgelegenheid voor een bepalde

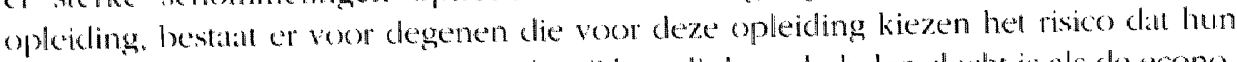
arletismarktpositie op het moment diat zij hun diploma behalen slecht is als de economic dan in een dal verke"ert. Bowendien is er in dall geval sprake van een onzekere werkgelegenheidssituatie op langere termijn. vanwege de grote kans op loekomstig batanverlies als de conjunctuncyclus zich herhatalt, en de economie weer in een dal werehtkomt. Zoals earcler in dit rapport is atungegeren, ligt an de toekomstige arbeidsminkiperspectionen roor de periode $2001-2006$ een gemiclelelde jaarlijkse werkgelegenhedickgroei wan 1.2\% ten gronclislag. Dil kan historisch gezien als een redelijk gunstige werkgelegenhe whontwikkeling worden beschourd. en kom natan 
verwachting ook overeen met een evenwichtig groeipad van de economie tot 2006 (zic hoofdstuk 1).

In tabel 3.7 is voor schoolverlaters met een bepaald toekomstig arbeidsmarktperspectief de gevoeligheid voor de conjuncturele fluctuaties in de werkgelegenheid weergegeven". Uit de tabel volgt dat voor ongeveer een kwart van de schoolverlaters het toekomstige arbeidsmarktperspectief onafhankelijk is van de conjuncturele ontwikkelingen. Deze schoolverlaters thebben veelal een opleiding gericht op de zorgsector. maar er zijn eveneens schoolverlaters van opleidingstypen buiten deze sector wiens baankansen nauwelijks onderhevig zijn aan conjuncturele fluctuaties, zoals VMBO administratie, bandel en mode, MBO milieu en groene nimte, HBO bibliotbeck en documentatie en WO theologie.

Tabel 3.7

Percentage schoolverlaters met verwacht arbeidsmarktperspectlef tot 2006 in relatie tot de conjunctuurgevoeligheid van de werkgelegenheid

\begin{tabular}{|c|c|c|c|}
\hline & $\begin{array}{r}\text { slecht of matig } \\
\text { perspectief }\end{array}$ & $\begin{array}{r}\text { redelijk } \\
\text { perspectlef } \\
\%\end{array}$ & $\begin{array}{l}\text { (zeen) goed } \\
\text { perspectlef } \\
\%\end{array}$ \\
\hline (Erg) lage conjuncturgevoeligheid & 26 & 23 & 25 \\
\hline Gemiddelde conjunctururgevoeligheid & 64 & $6 !$ & 41 \\
\hline (Erg) hoge conjunctuurgevoeligheid & 10 & 16 & 34 \\
\hline Totaal & 100 & 100 & 100 \\
\hline
\end{tabular}

Bron: ROA(POA)

Aan de andere kant heblen de schoolverlaters met een redelijk toekomstig arlecids-

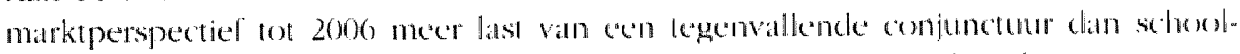
verlaters met een slecht of matig perspectict Dil gekelt in nog veel sterkete mate veon

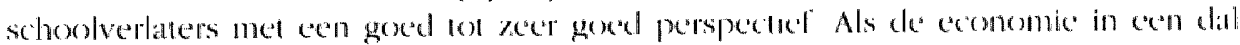
terechtkomt zal rum eenderde deel van de schoolverlaters voor wie nu con gunstig perspectief op de arbeidsmarkt wordt voorzien, het risico van een lorse versted blering

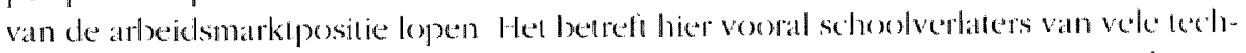
nische en in mindere mate economische opleidngstypen die het me'ste risico lopen,

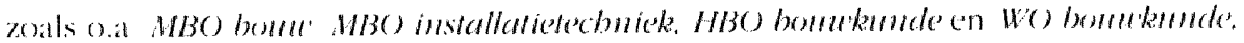

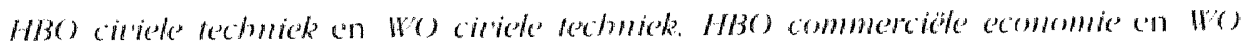
borlitifisumate

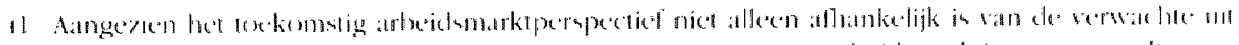

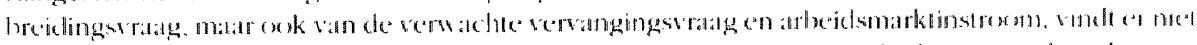

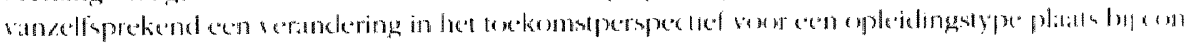
functurele fluctuaties. 


\subsection{Toekomstige knelpunten in de personeelsvoorziening naar beroep}

\section{Knelpunten voor werkgevers naar beroepsklasse}

In de voorgaande paragraaf is een overzicht gegeven van de knelpunten in de personeelsvoorziening, verbijzonderd naar opleidingscategorie, waarmee werkgevers naar verwachting zullen worden geconfronteerd. Deze aansluitingsproblematiek zal zijn weerslag hebben op de arbeidsmarkt voor de verschillende beroepsgroepen. Wanneer voor een bepaald beroep kennis en vaardigheden vereist zijn die met name aanwezig zijn bij mensen met een bepaalde opleidingsachtergrond waarvoor grote tekorten worden verwacht, zullen werkgevers grote moeite hebben personeel te vinden dat over de in dat beroep vereiste kwalificaties beschikt. Wanneer het hier over zeer beroepsspecifieke expertise gaalt, zullen de knelpunten extra groot zijn, aangezien er weinig alternatieven voorhanden zijn. Wanneer het daarentegen meer algemene competenties betreft, kan de werkgever alternatieve bronnen (opleidingen) aanboren.

Om beter inzicht te verschaffen in de wijze warop de in dit hoofdstuk geschetste aansluitingsproblematiek tussen onderwijs en arbeidsmarkt zijn weerslag heeft op de wervingsproblematiek in de verschillende beroepsgroepen, wordt gebruik gemaakt van de Indicator Toekomstige Knelpunten in de Personeelsvoorziening naar Beroepsgroep (ITKB). De ITKB geeft aan in welke mate het voor werkgevers mogelijk is om binnen beroepen de gewenste personeelssamenstelling naar opleidingsachtergrond te realiseren, gegeven de vraag-aanbod-verhoudingen voor de verschillende opleidingstypen. De 1TKB heeft een waarde tussen 0 en 1 . Naarmate de indicator lager wordt, zijn de knelpunten groter voor de opleidingstypen die voor de betreffende beroepsgroep relevant zijn. Werkgevers zullen dan relatief veel moeite hebben nieuw personeel met de door hen gewenste opleidingsachtergrond te vinclen. Wanneer de ITKB daarentegen dicht bij 1 ligt, zullen werkgevers weinig moeite hebben de gewenste personeelssamenstelling binnen het beroep te realiseren. Voor die opleidingen die andacht schenken aan de in datt beroep) relevante kenuis en vatadigheden, worden dan geringe knelpunten verwacht.

Inzicht in de knelpunten natr beroep is voor verschillende gebruikers en gebruiksdoelen relevant. Op de ecrste plats wordt door werkgevers de behoefte atan nieuw personeed primair geformuleed in termen van functiecategorieën of beroepen. Zij zijn immers op zock natr jemand die bepaakle taken - gebundeld in een bepaalde functiecallegorie - binnen de organisattie kan vervullen. Voor werkgevers kan inzich in de knelpunten naar berwepsgroep derhalve van belang zijn voor hun wervings- en personeedslekeik. Op de tweede platats kunnen (langdurig) werklozen of werkenden die op zock zijn natar een andere werkkring gebruik maken van de inlormatie over de knelpunten in cle personectsvoorziening nata beroep in hun orientatie natar een nieuwe of andere werkkting. Natuw met het tweede gebruiksdoel samenhangend zijn de bij- en omsicholingsprogtammas, omdat deze doorgatans gericht zijn op een bepaald beroep. Inzicht in de knelpunten nat beroep kan derhalve een leidrad zijn bij het vormgeven en inrichten van dergelijke scholingsprogramma's.

tit tabel 3.8 blijkt dat de verwachte knelpunten in de personeelswoorziening natar 
beroepsklasse voor de periode 2001-2006 in het algemeen groot zijn. De pedagogische beroepen en de medische en paramedische beroepen geven de grootste toekomstige knelpunten in de personeelsvoorziening te zien. Dit wordt voornamelijk veroorzaakt door de hoge vervangingsvraag en de lage arbeidsmarktinstroom van schoolverlaters met een geschikte opleidingsachtergrond voor deze beroepen. Dit betekent dat knelpunten in de personeelsvoorziening voor de beroepen in het onderwijs en de zorg de komende jaren het grootst blijven. Voor de agrariscbe beroepen, de transportberoepen en de verzorgende en diensterlenende beroepen worden daarentegen vrijwel geen knelpunten verwacht, waarvoor gedeeltelijk de relatief lage uitbreidingsvraag van deze beroepsklassen verantwoordelijk is.

Tabel 3.8

Indicator toekomstige knelpunten in de personeelsvoorziening naar beroepsklasse (ITKB),

2001-2006

\section{Beroepsklasse}

Pedagogische beroepen

Culturele beroepen

Agrarische beroepen

Technische en industrieberoepen

Transportberoepen

Medische en paramedische beroepen

Economisch-administratieve beroepen

Infomaticaberoepen

Sociaal-culturele beroepen

Verzorgende en dienstvertenende beroepen

openbare orde- en veiligheidsberoepen
ITKB

0,86

0,92

0,96

0,94

0,96

0,87

0,93

0,90

0,92

0,97

0,89 typering

zeer gloot groot viljwel geen grool vrijwel geen zeer grool. groot grool groot vrijwel geen groot

Bron: ROA(POA)

\section{Verdeling van werkenden naar knelpunten}

Tabel 3.9 geeft een beeld van de" verdeling van de werkenden binnen de beroepuklisssen nar de typering van de toekomstige knelpunten tn de personeclsvoorzienng. Voor de arbeidsmarkt als geheel laat de tabel zien dat maar liefst $55 \%$ van cle werkenden in beropen werkzam is met grote of zeer grole knelpunten. Slechts $10 \%$, van de werkenden heeft een beroep walrvoor entge knelpunten in de personeelsvoorziening worden verwacht, en $35 \%$ is werk talam on een beroep warvoor geen of vrijwel geen knelpunten worden verwacht" Uit tabel $3.9 \mathrm{koms}$ andermalal duidelijk natar voren datl de'

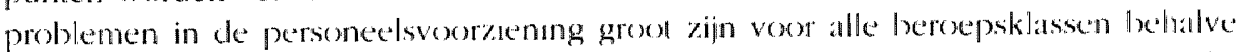

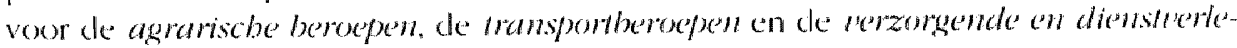
nende beroepen.

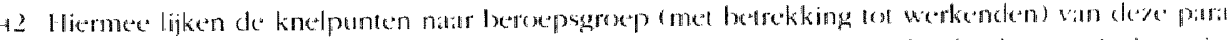

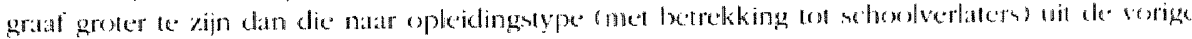
paratigraat 
Tabel 39

Percentage werkenden naar de typering van de verwachte knelpunten in de personeelswoorziening naar beroepsgroep (ITKB) in 2006

Beroepsklasse

Pedagogische beroesen

Culturele beroepen

Agrarische beroepen

Technische en industrieberoepen

Trunsportberoeten

Medische en paramedische beroepen

Rconomisch-administratieve beroepen

Informaticaberoepen

Soclaal-culturele beroepen

Verzorgende en dienstverlenende beroepen

Openbare orde- en veiligheidsberoepen

Totalal

Bron: ROA(POA)

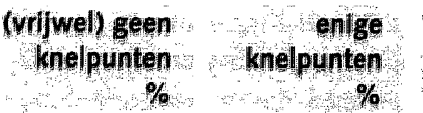

(zeer) grote

knelpunten

\section{$\%$}

97

77

5

53

11

91

75

67

6

100

55

Binnen cle beroepsklasse pedagogiscbe beroepen zijn de zureminstructeurs en de sportinstructeus de enige beroepsgroepen waarvoor werkgevers vrijwel geen knelpunten hoeven te verwachten. De toekomstige knelpunten in cle personeelsvoorziening voor de cullurele beroepen zijn nat verwachting eveneens groot. Vooral de beroepsgroep van geestelijken kenmerkt zich door erg grote knelpunten. Alleen voor de beroepsgroep van grafisch onturerpers worden er geen knelpunten verwacht. De agrariscbe beroepen tonen vrijwel geen toekomstige knelpunten. Gezien de lage groeiverwachtingen voor de agarische sector is dal niet verwonderlijk. De beroepsgroep van milieubygiënisten

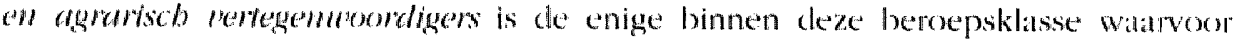
werkgevers grote knelpunten zullen ervaren.

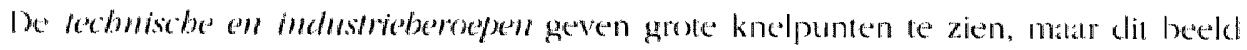
gelde nie voor de gehele beroepsklasse. De beropsklasse is opgebouwd wit een atan-

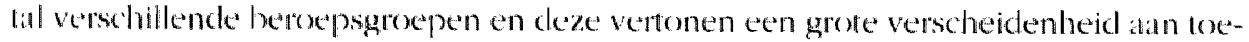
komslige knelpunten. Werkgevers die personeel werven voor de beroepsgroepen l'eg"on waterbonukumdige arbeiders, grafisch productiepersomed. mechanisch operatomen

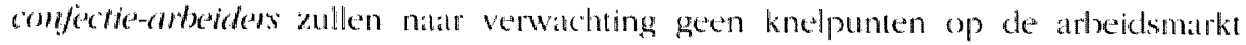
ondervinden. Heel anders is het beesd voor de weg- an waterbonthandigent, de

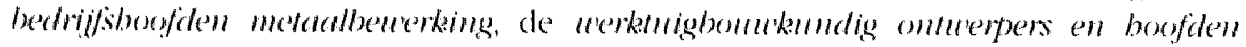
lechnische diemst en de elektrolechnici. Voor dexe beroepsgenepen zullen natar verwikhting grote personele problemen bestatan.

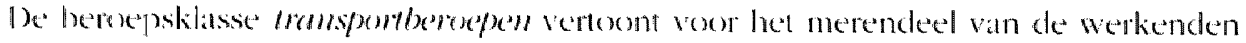
rrijwel geen knelpunten. 1)it komm met name door de gaxte beroepsgroepen laders en

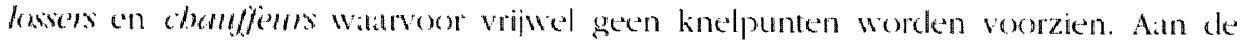
andere kiant zijn cle knelpunten wel grost voor de andere beroepsgroepen van deze

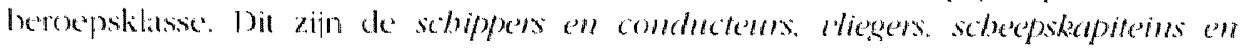




\section{leidinggevenden transport, en stewards.}

De medische en paramedische beroepen vormen, nast de pedagogiscbe beroepen, de beroepsklasse waarvoor zeer grote toekomstige knelpunten worden verwach. De knelpuntenproblematiek is het grootst woor de beroepsgroep venplegenden en doktewasistenten, terwijl werkgevers van de beroepsgroep apotbekes daarentegen slechts enige knelpunten zullen ervaren. Hiermee steekt de laatsigenoemde beroepsgroep relatiel gunstig af tegen andere beroepsgroepen binnen deze beroepsklasse.

Grote knelpunten worden verwacht binnen de grote beroepsklasse van de economischadministratieve beroepen. Dit geldt met name voor de beroepsgroepen economen, organisatieadviseurs en accountants. Minder grote knelpunten in de personeelsvoorziening worden verwacht voor de kantoorbulpen, inpakkers en colportews en de receptionisten en administratieve employees.

De twee beroepsklassen informaticaberoepen en social-culturele beroepen hebben naar verwachting grote toekomstige knelpunten in de personeelsvoorziening. De enige beroepsgroep in deze twee klassen met een relatief gematigde knelpuntenproblemattick aangaande de werving van personeel is de beroepsgroep van programmeurs. De rerzorgende en dienstverlenende beroepen hebben als geheel vrijwel geen knelpunten. maar dat geldt niet voor de beroepsgroepen cafe- en snackbarbonders en bedriflsboofden boreca. De openbare orde-en veiligheidsberoepen ten slote vertoont grote toekomstige knelpunten. Dit geld zowel voor de beroepsklasse als geheel, als voor alle onderliggende beroepsgroepen.

\section{Knelpunten in de personeelsvoorziening en substitutiemogelijkheden voor werkgevers}

De substitutiemogelijkheden voor werkgevers geven aan in hoeverre werkgevers voor een bepaald beroep arbeidskrachten kunnen aantrekken met een uiteenlopende opleidingsachtergrond, zodat ze niel afhankelijk zijn van het arbeidsambod van een bepaald opleidingstype De substitutiemogelijkheden kunnen worden bepatald meel behulp van een spreidingsindex van opleidingen binnen de beroepsgroepen. Heefi cen werkgever grote substitutiemogelijkheden dan kan dil zijn knelpunten wellich verlichten De werkgever kan dan immers besluiten schoolverlaters en werkzockenden van andere opleidingstypen dan de opleidlingstypen valn de eerste vororkear aan te nemen, ceventueel ten koste van enig productiviteitsverlies. Voomwardle - wil din inderdatad esen oplos. sing zijn - is dat er van de andere opleidingstypen voldoende atabod kan worden dangetrokken

Taldel 310 latal zien dall er naluwelijks verschil is tussen de verdeling van werkenden natr substitutiemogelijken voor beresesgroepen warvoor (vrijwel) geen knelpunten worden verwacht in cle personedsvormenieng en beroepsgroepen walarvor siledten

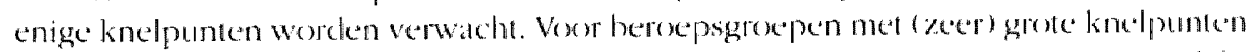
heeft de werkgever malar voor $25 \%$ van de werkenden (erg) kleine sulstituticumogedikheden. De heperkte substituriemogelijkheden vorr deze werkenden kunnen er or raiak van zijn dat de knelpunten in de persone lsvorgiening moeilijk kunnen worden opgelost voor werkgevers kan het van belang zijn om na ke galan of selexolverlatters van alternatieve opleidingstypen toch niel kunnen workten ingezel in sommige van dex

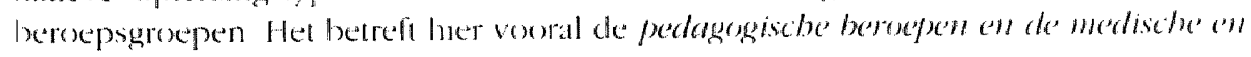


paramediscbe beroepen. Voorts blijkt uit de tabel 3.10 dat werkgevers voor $45 \%$ van de werkenden in beroepsgroepen mell (zeer) grote knelpunten tevens (zeer) grote substitutiemogelijkheden hebben. Dat de knelpunten voor deze beroepsgroepen ondanks de grote substitutiemogelijkheden toch aanzienjijk zijn, impliceen dat er voor de vele opleidingstypen binnen deze beroepsgroepen onvoldoende aanbod is. Werkgevers kunnen dan wellicht aanbodgroepen van de diverse opleidingstypen proberen te bereiken die voorheen niet werden aangeboord of de wervingsinspanningen te intensiveren ten aanzien van schoolverlaters voor de opleidingstypen die nog ondervertegenwoordigd zijn binnen de betreffende beroepsgroepen. Binnen de economiscbe-administratieve beroepen zou dit kunnen gelden voor de bedrifsboofden, organisatie-adviseurs, assistent accountants, commercieel employés.

Tabel 3.10

Percentage werkenden waarvoor knelpunten in de personeelsvoorziening tot 2006 worden verwacht in relatie tot de substitutiemogelijkheden van personeel voor werkgevers

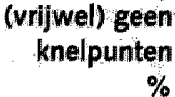

Percentage werkenden waarvoor

(erg) kine substifutiemogelijklieden

Percentage werkenden waarvoor

gemiddelde substitutienogelijkhedlen

Percentage werkenden waarvoor

(erg) grole stubstitutiemogelijkheden

Total

Bron: ROA(POA)
64

100

enige
knelpunten
$\%$

(zeer) grote

knelpunten 


\section{Het onbenutte arbeidspotentieel}

De sterk toegenomen krapte op de arbeidsmarkt beeft de laatste jaren geleid tot ven toenemende aandacht voor de mogelijkheden om bet onbenutte arbeidspotentieel in te schakelen. De werklozen vormen een belangrijk deel van bet onbenutte arbeidspotentieel omdat ze daadwerkelijk op zoek zijn naar betaald werk.". Het grootste deel van bet onbenutte arbeidspotentieel bestaat echter uit de zogeheten niet-participerenden. Deze mensen bieden zich om uiteenlopende redenen niet aan op de arbeidsmarkt: ze bebben buishoudelijke of zorgtaken, studeren, zijn arbeidsongeschikt, verrichten vrijwilligerswerk, zijn vervroegd met pensioen gegaan, etc. Vanuit de imolsboek van bet oplossen of verlicbten van de knelpunten op de arbeidsmarkt. zijn de niet-participerenden die aangeven beschikbaar te zijn voor de arbeidsmarkt relevam. Hun kansen op een eventuele berintrede zijn onder meer afbankelijk van persoonlijke achtergrondkenmerken als leeftij, opleidingsachtergrond, werkervaring en inactiviteitsdum. In verband biermee zullen in dit boofdstuk de volgende vragen centraal staan:

- In welke mate is bet onbenutte arbeidspotentieel qua omvang en samenstelling veranderd in de afgelopen jaren van boogconjunctuur?

- Hoe is de concurrentiepositie van werklozen en berintreders ten opziche wan schoolverlaters op de arbeidsmarkt?

- In welke mate kan bet onbenutte potentieel van werklozen en niet-participerenden, gezien bun persoonlijke acbtergrondkenmerken, voorzien in de toekomstige uraagbeboefte op de krappe arbeidsmarkt?

In paragraaf 4.1 wordt nader ingegaan op de definitie van het onbenutte arbeidspotentieel en op twee dimensies die van belang zijn vamuit bet oogpun van arbeidsaanbodgedrag: de bereidbeid en geschiktheid om (weer) te gaan werken. In paragrall 4.2 uordt de omvang en samenstelling van bet onbenutte arbeidspotentieel in 1999 vergeleken met bet potenticel in 1994. toe'n bet werkloosbeidspercentage bel hoogst fan

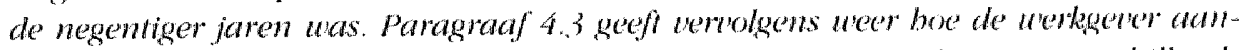
kijkt tegen de geschiktbeid wan werklozen en niet-participerenden met verschillonde acbtergrondkenmerken wat betreft inactivileilsduar. opleiding en enaring. Deze informatie spitst zich toe op de zorg- de metalat-en de 17 -sector In paraglaaf 4.4 word vertolgens in beeld gebracbl boe groot bet onbonutle arbeidspotentiod is tom. deze drie sectoren

\subsection{Inleiding}

Het onlenutte arbeidspotentieel bestat wit het potentied van werklozen en niel-participerenden. Niet-participerenden zijn personen vit de potentiële beroxpsbevolking (1.c. iedereen van 15 tot en met 64 jaar) die noch werkend noch werkloxs zijn. Zij vallen

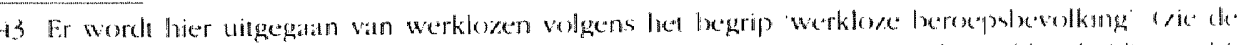

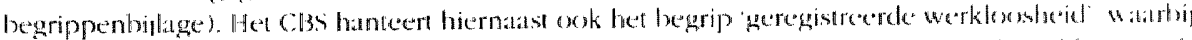

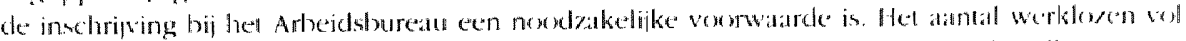

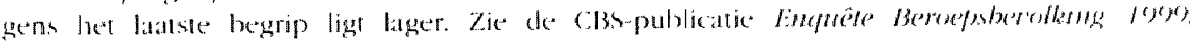
voofburg Ileerlen. 2000 . 
buiten de beroepsbevolking en worden niet tot het arbeidsaanbod gerekend. Deze definitiekwestie vindt zijn oorsprong in de indeling van personen uit de potentiële beroepsbevolking nat de bereidbeid om te werken. Indien men naar een baan zoekt. wordt er een grotere bereidheid getoond om werk te aanvaarden. Bovendien geeft ook de termijn waarop men een betaalde baan kan of wil aanvaarden, aan in welke mate

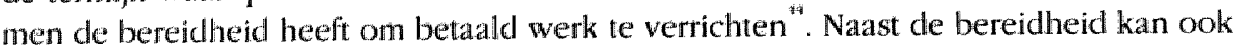
gekeken worden nat de geschiktbeid van personen uit de potentiële beroepsbevolking om betaald werk te verrichten. In beginsel kan ervan worden uitgegaan dat iedereen van 15 tot en met 64 jaar geschikt is om een bepaald beroep uit te oefenen. Vandaar dat de potentiële beroepsbevolking ook wel de beroepsgeschikte bevolking wordt genoemd. In werkelijkheid is echter maar een deel van dle potentiële beroepsbevolking geschikt om betaald werk te verrichten. Hieronder wordt ingegaan op de heterogeniteit van het onbenutte arbeidspotentieel onder werklozen en niet-participerenden ".

Voor de werklozen geldt dat zij tot op het moment van enquêtering geen baan hebben kunnen vinden, ondanks dat ze zich aanbieden op de arbeidsmarkt. Van belang hierbij is dat er altijd een gedeelte van de werklozen is dat na gedwongen of vrijwillig ontslag on welke reden dan ook (tijdelijk werk, bedrijfssanering, verhuizing, etc.) kortstondig op zoek is nata een nieuwe baan en die ook vrij snel vindt. De zoekduur van deze kortstonclig werklozen bepaalt in feite de minimale hoogte van de zogenande frictiewerkloosheid. Om een beeld te krijgen van de geschiktheid van werklozen kan dus gekeken worden nala de werkloosheidsduur, waarbij vaak het criterium van éen jaar wordt alangehouden voor het onderscheid tussen kortdurig en langdurig werklozen. Naturnatte personen langer werkloos zijn, zal het onder meer vanwege de veroudering van hun kennis en vaardigheden doorgaans steeds moeilijker worden om een betalde werkkring te vinden "."

Onder niet-participerenden worden personen gerekend die niet kunnen werken, niet willen werken, niet zoeken natr werk of niet op korte termijn beschikbaar zijn om werk le atunvataden. lit zijn veel mensen die niet participeten op de arbeidsmarkt omdat $x^{*}$ mbesdsomgeschilat zijn ol omdall ze zorglaken en huishoudelijke bezigheden hebhen Binnen de lxeterogene groep van niet-participerenden zipn er echter ook niet-participe-

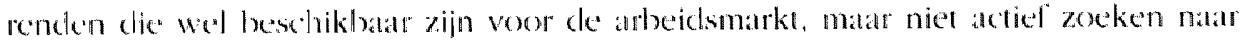
belaald werk. Dit zijn de beschikhare niet-participerenden, die zich op hel grenswlak valn werklossileid en nomparticipatic bevinden.

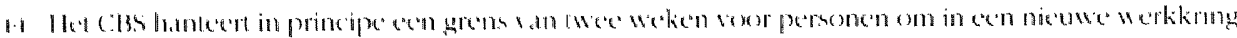

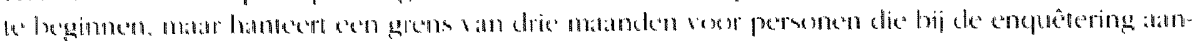

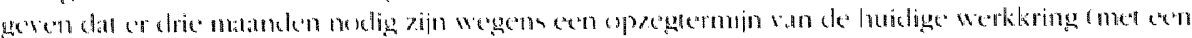

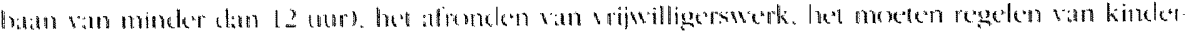

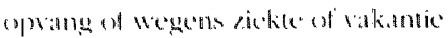

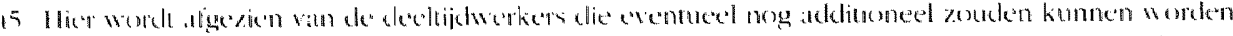

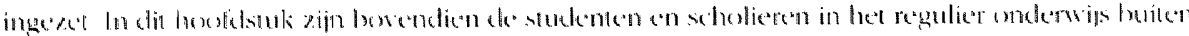

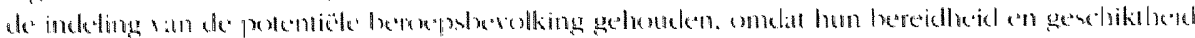

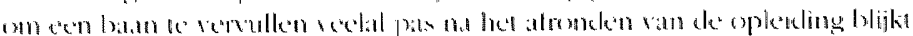

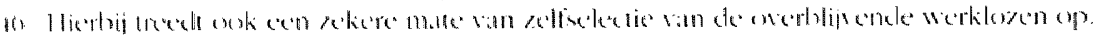


In de internationale literatuur worden de beschikbare niet-participerenden angeduid als 'discouraged workers". moedigd kunnen zijn door een slechte algemene arbeidsmarktsituatie met een hoge werkloosheid. waardoor ze geen zoekactiviteiten ontplooien. Deze invloed van hoge werkloosheid op het zoekgedrag staat bekend als het discoumged worker effect. Ook kunnen mensen na enige tijd werkloos te zijn geweest ontmoedigd aken ondat ze nog steeds geen baan hebben gevonden". Een werkloze zal dan stoppen mer zoeken, en derhalve vervolgens als niet-participerend worden beschouwd". In dit licht bezien is het te verklaren dat het reservoir van niet-participerenden ook wel stille reserve genoemd wordt.

De OECD heeft internationaal onderzoek verricht nat de relatie tussen werkloosheid en het aantal ontmoedigde niet-participerenden, 1.e. de beschikbare niet-participerenden ${ }^{50}$ Het blijkt dat in de meeste landen van de OECD het werkloosheidsniveau in de periode 1983-1993 positief samenhangt met het aantal 'discouraged workers'. Het onlsenutte arbeidspotentieel van zowel werklozen als beschikbare niet-participerenden fluctueert dus mee met de conjunctuur. Voor Nederland kon echter het verband russen werklozen en 'discouraged workers' niet worden vastgesteld. Mogelijkerwijs beefi de kortere periode warover gegevens beschikbaar waren voor Nederland (1987-1943) hierbij een rol gespeeld.

Uit ander onderzoek blijkt dat de werklozen en beschikbare niel-participerenden op elkaar lijken wat betreft de kans op het aanvaarden van een betaalde baan (cle bainvindkans) ${ }^{5}$. Dit dus in tegenstelling tot hun zoekgedrag. Een reden voor de vergelijkbare baanvindkansen is dat de kans op herintrede kleiner is narmate het langer geleden is dat men betalt werk heeft verricht, evenals dat bij werklozen met betrekking tox de werkloosheidsduur geldt. Hierbij moet wel de kanttekening worden genaaki dat de kans op het vinden van een baan door niet-participerenden in belangrijke mate word bepaald door hun leeftijd en geslacht en de regio waar ze wonen. Het onderzoek naa de batanvindkans wan werklowen en net-participerenden leidt echter nied tor ecenduklige" resultaten. onder meer vanwege de grote heterogeniteil in de groep van niel-panticiperenden "

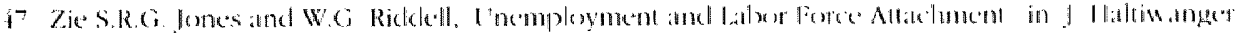

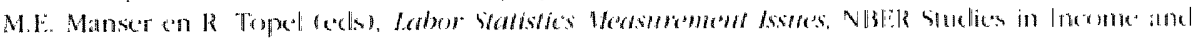

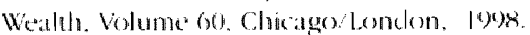

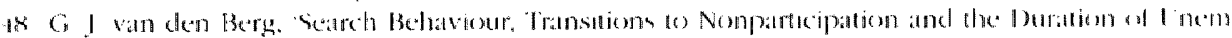

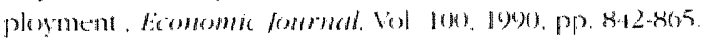

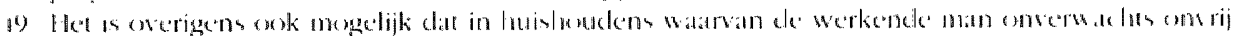

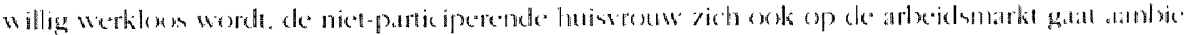

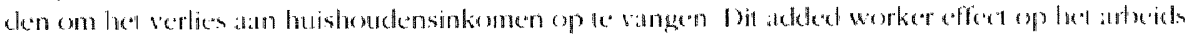

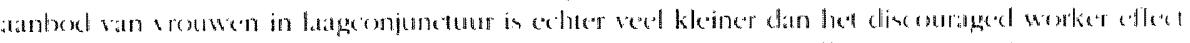

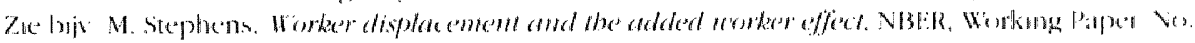
R260. 20011

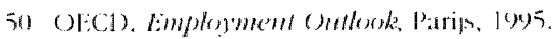

it gones con Riddell. op sit

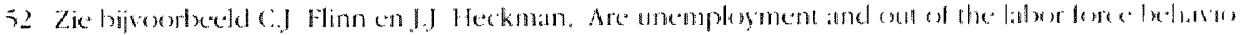

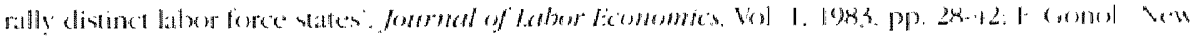

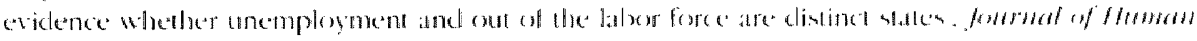

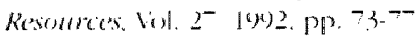


Nederland heeft gedurende het latste decennium zowel laag- als hoogconjunctuur gekend. Terwijl in 2000 de werkloze beroepsbevolking minder dan $4 \%$ uitmaakte van de beroepsbevolking (werkenden en werklozen), was dat in 1994 nog ruim $8 \%$. Uit de volgende paragraaf zall blijken dat zich ook aanzienlijke daling heeft voorgedaan van het aantal niet-participerenden van het onbenutte arbeidspotentieel. Tevens wordt er gekeken naar de achtergrondkenmerken van werklozen en niet-participerenden. Op basis van de eerder genoemde dimensies bereidheid en geschiktheid kan een oordeel worden gevormd over de kwaliteit van het onbenutte arbeidspotentieel gedurende laag- en hoogconjunctuur.

Voor een analyse van de flexibiliteit van het arbeidsaanbod is het van bijzonder belang om te weten of niet alleen het reservoir van werklozen meedeint op de golven van de conjunctuur, maar of hetzelfde geldt voor (een deel van) de niet-participerenden. Als het arbeidsaanbod vanuit de categorie van niet-participerenden reageert op de conjunctuur, is er reden te meer om de niet-participerenden daadwerkelijk als een 'stille reserve' te bestempelen die ten tijde van hoogconjunctuur kan worden ingezet. Deze 'stille reserve' zal bij een eventuele overgang naar een ruimere arbeidsmarkt mogelijk weer toenemen. Er dient derhalve rekening mee gehouden te worden dat bij een eventuele toekomstige tegenvallende conjunctuur de doorgroei van de arbeidsparticipatie zal stagneren ${ }^{5.3}$. Tot slot dient er rekening mee te worden gehouden dat ook sociale en culturele veranderingen de toename van de arbeidsparticipatie van met name vrouwen over een langere termijn bepalen ${ }^{51}$.

\subsection{Ontwikkeling en kenmerken van het onbenutte arbeidspotentieel}

De bereidheid en geschiktheid van personen om betaald werk te verrichten zijn twee belangrijke dimensies op basis waarvan personen van het onbenutte arbeidspotentieel kunnen worclen ingedeeld. In de studie van het ROA Naar een Employability Monitor" wordt uitgebreid ingegaan op de vraag welke belemmeringen personen kunnen ondervinden om werk te verkrigen. Deze belemmeringen, die verband houden met de bereidheid en geschiktheid om betaald werk te verrichten, kunnen zeer divers zijn. De belemmeringen kunnen bijworbeeld betrekking hebben op de bereiklheid om een opleiding re volgen of te verhuizen, de persoonlijke situatie in het huishouden, zoals de samenstelling van het huishouden en de leeftijd van eventuele kincleren, malar ook de arteidsmarliperspectieven, de competenties en de inativiteitsduur. In cleze paragraal wordt gekeken nilar een beperkt aantal factoren die met bereidheid en geschiktheid samenhangen, watabij bovendien de samenhang met de conjunctuur zichtbar wordt gemaial. Datanaist word gekeken hoe diverse achergrondkenmerken van de werklozen en de niet-participerenden zich verhouden ten opzichte van de werkenden.

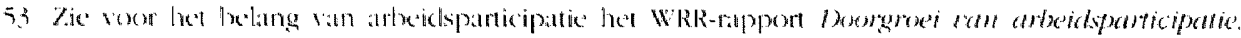
Nr. $5-1$. Den Haing, 2000

5. M. Vondrik. Collective habits and social noms in labour supply. From micromatives to macrobebareotr: Disientation no, 93-18, I niversite it Matastricht. 1993

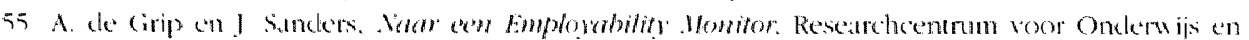
Alucidsmathi, Marastricht, 2000 


\title{
Bereidheid
}

In figuur 4.1 is een rangorde van de verschillende te onderscheiden groepen werklozen, beschikbare niet-participerenden en niet-beschikbare niet-participerenden weergegeven, in volgorde van een afnemende bereidheid om op de arbeidsmarkt te participeren. De werklozen die de afgelopen weken naar werk hebben gezocht, zijn kennelijk meer bereid om betaald werk te verrichten dan de niet-participerenden. Naarmate zij langer werkloos zijn, mag worden aangenomen dat de bereidheid om te gatan werken kleiner is. Voor het onderscheid tussen kort-en langdurig werklozen wordt valak de min of meer arbitraire grens van een jaar genomen. Voor de beschikbare niet-participerenden geldt dat een deel van hen gedurende de laatste zes maanden heeft gezocht, terwijl het andere deel niet heeft gezocht. De onderverdeling naar bereidheid van de nietbeschikbaren is niet helemaal scherp te maken. Degenen die niet op korte termijn kunnen beginnen of arbeidsongeschikt maar bereid tot betaald werk zijn, worden verondersteld een grotere bereidheid te hebben ten opzichte van degenen die vervroegd zijn uitgetreden of mer pensioen zijn en degenen die geen betaald werk willen.

Figuur 4.1

Onbenut arbeidspotentieel naar afnemende bereidheid om betaald werk te verrichten

\section{Werklozen}

- afgelopen vier weken gezocht, kan op korte termilin beginnen, minder dan een jarar werkloos

- afgelopen vier weken gezocht; kan op korte termijn beginnen, meer dan een jaar werkloos

\section{Beschikbare niet-participerenden}

- afgelopen half jaar werk gezocht, kan op korte termijn beginnen

- afgelopen half jaar geen werk gezocht, kan op korte termijn beginnen

\author{
Niet-beschikbare niet-participerenden \\ - kann niel op korte termijn beginnen \\ - arbeidsongeschikt, wel bereid tot betalald werk \\ - VUT' of pensioen \\ - wil geen werk
}

Bron: CBS(EBB)

Tabel 4.1 geeft de onvang en de verdeling van de onderscheiden groepen werklosen en net-participerenden weer un 1994 en 1999 Deze tabel geeft derhalve inzoth in cke bereidheid van het onbenute arbeidspotentieel om betaald werk te verrichten bij latigrespectevelijk hoogconjunctur thet onbenutte arbeidspotenticed is tussen 196) en 1999 duidelijk gedaald. Het andeel van de werklowen in het onlenulte arbeidspotentieel is tussen 1994 en 1999 met 6 procentpunten aanzienlijk afgenomen. Ook het joercentage niet-participerenden dall beschikbaar is voor de arbeidsmarkt is duicledijk gedaald, hetgeen een indicatie dijkt te zijn voor het bestat van het discouraged worker effecl bij de ruime arbeidsmarkt van 1994. Relatief gezien is de groep beschikbarce nictparticiperenden die het half jar voorafgaande aan de enquêtering heh hen ge\%ocha nata betaald werk, hel meest gedaald. Op basis van bun zoekgedrag lijken zij nog loct mee'st op de werklozen. Verder is het a antal en percentage toegenomen van de niet-participerenden die niet op korte termijn beschikbaar zijn. I) arlxeidsongeschiklen die |xereic| 
zijn om te werken zijn zowel absoluut als relatief aanzienlijk toegenomen. Verder heeft zich tussen 1994 en 1999 een aanzienlijke daling voorgedaan van het aantal mensen dat niet wil werken, en dus ook niet beschikbaar is voor de arbeiclsmarkt. Deze categorie is als percentage van het onbenutte arbeidspotentieel echter wel toegenomen.

Tabel 4.1

Onbenut arbeidspotentieel, excl. studenten en scholieren

Categorie

Werkloos

Beschikbaar, werk gezocht

Beschikbaar, niel gezochı

Nict op korte termijn beschikbaar

Arbeidsongeschikt, bereid tot werk

VUT' of pensioen

Wil niel werken

Totaal onbenut arbeidspotentieel

\begin{tabular}{rrrr} 
& 1994 & & \multicolumn{2}{c}{1999} & \\
aantal & $\%$ & aantal & $\%$ \\
492.500 & 15 & 255.000 & 9 \\
108.500 & 3 & 59.500 & 2 \\
219.000 & 7 & 156.500 & 6 \\
195.500 & 6 & 196.500 & 7 \\
67.500 & 2 & 144.000 & 5 \\
259.000 & 8 & 267.000 & 9 \\
2.007 .500 & 60 & 1.762 .000 & 62 \\
3.349 .500 & 100 & 2.840 .500 & 100
\end{tabular}

Bron: CBS(BBB)

In het algemeen kan worden geconcludeerd dat de onvang van het onbenut arbeidspotentiet aanzienlijk is gedaald, terwijl ook de samenstelling ten ongunste is veranderd. Hel aandeet personen in het onbenutte arbeidspotentieel dat werkloos is of beschikbaar is voor werk, is van $25 \%$ in 1994 nar $17 \%$ in 1999 gedaald. Daarentegen is voor de vier cattegorieën van niet-participerenden die niet beschikbaar voor de arbeidsmarkt zijn, het aandeel in het onbenutte arbeidspotentieel juist toegenomen. Dit hangt wararschijnlijk voor een bellangrijk gedeelte samen met de verbeterde conjunctuur sinds 1994. walardoor degenen die het meest bereid waren om betald werk te verrichten datar ook vors een belitngrijk deet reeds in zijn gestalagd.

\section{Geschiktheid}

De gesthiktheid van personen wit de potentiële beroepsbevolking on betald werk te verkriggen word txepaiald door verschillende firctoren als gezondheid, opleiding, ervalring. inaclivileitseluur, persoonlijkheid, flexilbiliteit en ambitie Gezonde personen zijn vanzelfsprekend in het algemeen beter geschikt te werken dan arbeidsongeschikten. Ook het at dan nive helblen van de juiste opleidlingsichtergrond bepalt in belangrijke matte de kans op een goede batan. Van groot belang is echter dat de invloed van de opledidingsiathtergoond op de kans op heat verrichten van betaald werk in sterke mate

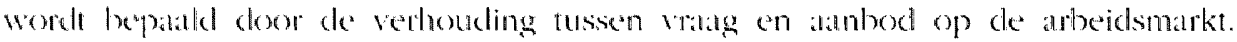
De geschilitheid geeti vanuit dit gezichtspunt onder andere weer hoe antrekkelijk iemand voor werkgevers is. Datathij spelen de allnsluting tussen opleiding en beroep. de breche van een opleiding en de concurrentiepositie ten opzichte van andere opleidingen ook een rol. Aangezien de arbeidsmarkt dynamisch is, kan de gesdhiktheid van personen met een bepalakle opleiding root het vinden van een betalde bean in de loop der tijal ten voordele of juist ten nadele veranderen. 
Een indicatie van het gemiddelde opleidingsniveau van de verschillende groepen van het onbenutte arbeidspotentieel wordt weergegeven in tabel 4.2. In de tabel wordt weergegeven hoe groot het percentage mensen met een MBO-opleiding of hoget is in elke categorie in 1994 en 1999 . Een MBO- of een daaraan gelijkwaardige opleicling als HAVO of VWO wordt vaak beschouwd als de minimale startkwalificatie op de arbeidsmarkt. Wat betreft de arbeidsmarktperspectieven lijkt er daactwerkelijk sprake te zijn van een tweedeling tussen enerzijds mensen met een opleiding op slechts $\mathrm{BO}$ of VMBO-niveau, en anderzijds mensen met een MBO-opleiding of hoger (zie hoofdstuk 1) ${ }^{\text {ic }}$. Bovendien lijkt een opleiding op MBO-niveau of hoger van belang te zijn voor de employability van personen, waaronder de mogelijkheden om molxiel te zijn tussen beroepen of sectoren van cle economie

In het algemeen blijkt uit tabel 4.2 dat naarmate de bereidheid daalt om betald werk te verrichten, ook het percentage mensen daalt dat minimal een MBO-opleiding heeti Uitzonderingen hierop zijn de niet-participerenden die niet op korte termijn beschilkbaar zijn en degenen die vervroegd zijn uitgetreden of met pensioen zijn. Het algemene beeld dat de bereidheid om te werken en het opleidingsniveau samenhangen is in overeenstemming met de buman capital theorie . Uit deze theorie volgt dat het alleen atmtrekkelijk is om te investeren in menselijk kapitaal als deze investeringen terugverdiend kunnen worden op de arbeidsmarkt. Hoe hoger de afgeronde opleiding, hoe groter de kosten van het volgen van deze opleiding (school- en collegegeld, overige studiekosten voor bijvoorbeeld boeken, kosten van niet-werken, etc.), en hoe groter de 'prikkel' om de kosten terug te verdienen door betaald werk te aanvatrden Bovendien zijn de kosten van het niet-werken (de zogenaamde 'opportunity cost') in het algemeen groter naarmate de gevolgde opleiding hoger is, omdat het potentieel te verdienen marktloon hoger is. Bijvoorbeeld, iemand die het MBO heeft afgerond, zal als gevolg van de keuze om huishoudelijke taken te verrichten doorgaans grotere "opportunity cost" helben dan iemand met een VMBO-opleiding.

Uit tabel 4.2 blijkt verder dat het oplesdingsniveau van de werkende beroepsbevolkmg tussen 1994 en 1999 is gestegen. Het percentage personen met minimal een Ml30)opleiding nam met drie procentpunten toe lot 72 procent De toename in procempunten ligt echter lager voor alle categorieën van het onbenulte arbeidspotentied, met uilzondering van degenen de niet willen werken en de werklozen voor de beschiklatre niet-participerenden is het percentage personen met minimat een Ml3O-opleading constant gebleven De arbeidsongeschikten die beregd zijn om te werken hebben witctabur een achterstand wat betreft hun gezondheid, matr heblen ook samen med degenen dic net willen werken, het laagste andeet personen met minimat een MBO-topleiding.

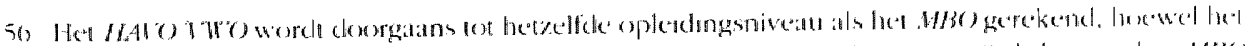

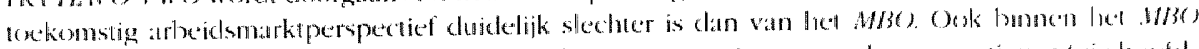

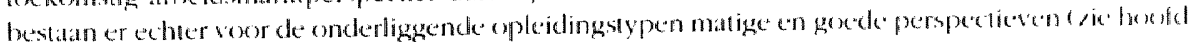
stuk 2)

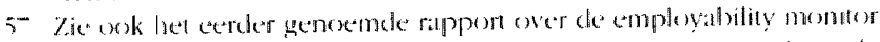

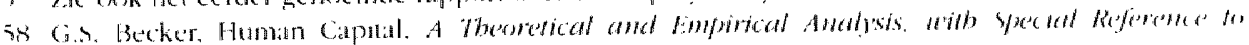

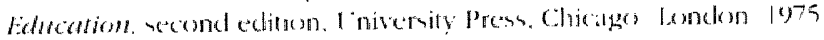


Tabe 4.2

Onbenut arbeidspotentieel, excl. studenten en scholieren, aandeel met minimaal MBO-niveau of hoger

\section{Categorie}

\begin{tabular}{|rr}
1994 & 1999 \\
$\%$ & $\%$ \\
\hline 53 & 56 \\
45 & 45 \\
43 & 43 \\
52 & 54 \\
41 & 39 \\
63 & 64 \\
35 & 40 \\
42 & 45 \\
69 & 72
\end{tabular}

\section{Werkloos}

Beschikbaar; werk gezocht

Beschijbaar, niet gezocht

Niel op korte termin beschikbar

Arbeidsongeschikt, bereid not werk

Vit' of pensioen

Wil niet werken

Total onbenut arbeidspotentieel

Total werkende beroepsbevolking

Bron: CBS(BBB)

Uit tabel 4.2 volgt dat de geschiktheid van het onbenutte arbeidspotentieel op basis van het aandeel personen met een minimaal een MBO-opleiding tussen 1994 en 1999 is toegenomen met 3 procentpunten. Het opleidingsniveau van het totale onbenutte arbeidspotenticel is evenveel toegenomen als voor de totale werkende beroepsbevolking. Het aandeel personen in het onbenutte arbeidspotentieel met minimaal een MBO-opleiding ligt echter nog altijd beduidend lager dan het gemiddelde voor de werkende beroepsbevolking. Er kan worden geconcludeerd dat wat betreft het opleiclingsniveau de achterstand van het onbenutte arbeidspotentieel ten opzichte van de werkenden tussen 1994 en 1999 groot is gebleven. Dit betekent dat het niet participeren op de arbeidsmarkt vooral een zaak is van de lager opgeleiden.

De labellen 4.3 en 4.4 geven een beeld van de verschillende achtergrondkenmerken viln cle potentïle beroepsbevolking in 1999. De verschillende categorieën van het onlenutte arlxeidspotentieel kunnen onderling en met de werkenden worden vergeleken. In tabel 4.3 staan de werkenden en degenen die her meest bereid zijn werk te alanvatarden, terwijl tabel 4.4 een overzicht geefi van de achtergrondkenmerken van de vier catcgorieèn niet-participerenden die niet beschikbair zijn voor de arbeidsmarkt. Van de werkenden mel een baan van 32 uur of meer bijkt bijnal driekwart man te zijn. Onder de werkenden in deeltijd is 87 procent vrouw. Deze werkenden zijn bovendien relatied vatia in de leettijd van 30 tor 49 jatr. Deze groep van cleeltijdwerkenden bestaat voolal wit vouwen die huishoudelijke taken met deeltijdwerk combineren. Voorts blijkt diat cle werkenden het grootste alandeel miklelbaar en hoger opgeleiden hebben, en het kileinste andext litger opgeleiden.

Onder de werklozen is een onderscheid gentakt tussen degenen die vanaf hun 15 e jatar in tolat mincker tan een jatr of meer dan een jala werkloxs zijn geweest". Naast andere achtergrondkemmerken als lectrijd en opleiding. beinvloedt de inactiviteitsduur op

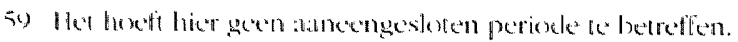


zichzelf ook de werkloosheidsduur vanwege het eerder besproken ontmoedigingseffect, maar ook vanwege het verlies aan kennis en vaardigheden en het negatieve signaal aan werkgevers ${ }^{\text {sil }}$. Het is opvallend dat met name de jongeren onder de kortdurig werklozen sterk oververtegenwoordigd. zijn. Bij een tegenvallende conjunctuur lopen zij het risico langer werkloos te worden, waardoor hun kans op werk verder afneemt. Vrouwen zijn oververtegenwoordigd onder de werklozen: ongeveer $60 \%$ van de werklozen is vrouw. Eerder werd al duidelijk dat het gemiddelde opleidingsniveau van de werklozen lager is dan dat van de werkenden.

Onder de niet-participerenden die beschikbaar zijn voor de arbeidsmarki zijn veel vrouwen van middelbare leeftijd. Met name de vrouwen die werk hebben gezocht zouden vanwege hun bereidheid om betaald werk te hebben, kunnen worden ondersteund bij hun zoekactiviteiten. Meer dan de helft van de beschikbare niet-participerenden is echter lager opgeleid. Voor de personen in de relatief grote groep van beschikbare niet-participerenden in de leeftijdsklasse van 50 tot en met 64 jaar mag worden aangenomen dat $z e$, in combinatie met andere factoren als langdurige inactiviteit, een lage opleiding en geringe inspanningen voor het verwerven van een baan, een kleine kans hebben op een betaalde baan .

Tabel 4.3

Werkenden, werklozen en beschikbare niet-participerenden van de potentiële beroepsbevolking, excl. studenten en scholieren, naar achtergrondkenmerken, 1999

\section{Kenmerk}

werkend

$\begin{array}{rr}\text { vanaf } 32 & 12-32 \\ \text { uur } & \text { uur } \\ \% & \%\end{array}$

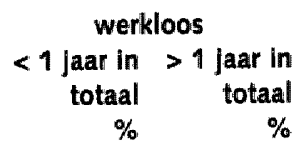

39

61

Vrouw

Leeftijd

$15-29$ jaar

30-49 jaar

50-64 jaar

Opleiding

BO-NMBO

MBO-HAVO-WWO

HBO-WO

Total

Aantal

Bron: CBS(EBB)
26

\section{3}

87

$27 \quad 15$

55

18

64

21

27

44

29

$\begin{array}{rr}100 & 100 \\ 15.173 .000 & 1.421 .500\end{array}$
29

45

26

100

84.000

\begin{tabular}{rr}
\multicolumn{2}{c}{ beschlkbaar } \\
werk & nlet \\
gezocht & gezocht \\
$\%$ & $\%$
\end{tabular}

nlet

$\%$ 
Uit tabel 4.4 blijkt dat bijna $80 \%$ van de niet-participerenden die niet op korte termijn beschikbaar zijn, vrouw is. Deze vrouwen zijn veelal van middelbare leeftijd, en hebben een gemiddeld opleidingsniveau dat ongeveer gelijk is an dat van de langdurig werklozen, terwijl hun opleidingsniveau gemiddeld hoger is dan dat van de beschikbare niet-participerenden. Dit lijkt derhalve een belangrijke groep om eventueel op termijn tot participatie te bewegen.

De arbeidsongeschikten clie bereid zijn te gaan werken zijn relatief vaak laag opgeleid. Bijna de helft valt in de leeftijdscategorie van 50 tot 64 jaar. Voor deze mensen zal het in het algemeen moeilijk zijn om betaald werk te vinden.

Uit tabel 4.4 blijkt dat verder dat degenen die met pensioen of VUT zijn, het hoogste aandeet hoger opgeleiden en het laagste aandeel lager opgeleiden hebben onder de niet-participerenden die niet beschikbaar zijn voor de arbeidsmarkt. Gezien de krapte op de arbeidsmarkt voor hogere opleidingen blijft het interessant om de personen die in deze categorie vallen langer aan het werk te houden. Ook het stimuleren van een (gedeeltelijke) arbeidsmarktparticipatie door reeds gepensioneerden is een a antrekkelijke optie, hoewel dat in het licht van de relatief goede pensioenregelingen niet eenvoudig zal zijn.

Bij cle grote groep niet-participerenden die niet willen werken. blijken vrouwen. lager opgeleiden en personen uit de oudere leeftijdsklasse sterk oververtegenwoordigd te zijn. In het algemeen zal deze groep zeer moeilijk te bewegen zijn om betaald te gaan zoeken, terwij] ook deze groep vanuit het perspectief van de werkgevers waarschijnlijk weinig alantrekkelijk zal zijn.

'Tabel 4.4

Niet-beschikbare niet-participerenden van de potentiële beroepsbevolking, excl. studenten en scholieren, naar achtergrondkenmerken, 1999

Kenmerk

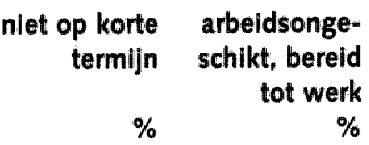

$\%$

$\%$

\section{Geslacht}

Min

Vionw

Leeftijd

$15-20$ jitil

30.49 |alit

50-64 jatar

Opleiding

BO-1M130

MBso-HAO-1WO

HBO $)$ WO

lotatil

A:ubtil

Brom: $\mathrm{CBS}(\mathrm{BBB})$
44

56

8

44

49

61

31

100

144.000

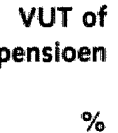

83

17 15 85

7 38 55 60 30 9

100 762.000 
In tabel 4.5 wordt een overzicht gegeven van de verdeling van de potentiële beroepsbevolking over de opleidingscategorieën. Per opleidingscategorie wordt het percentage werkenden, werklozen, beschikbare nier-participerenden en nier-beschikbare nietparticiperenden weergegeven ${ }^{1,2}$. Werklozen en beschikbare niet-participerenden ('discouraged workers') kunnen beschouwd worden als het deel van het onbenutte arbeidspotentieel van de betreffende opleidingscategorie warvoor de afstand tor de arbeidsmarkt het kleinst is. Het blijkt dat in alle opleidingstichtingen het onbenutte arbeidspotentieel als percentage van de potentiele beroepsbevolking daalt natamate het opleidingsniveau hoger is. Een verklaring hiervoor is al eerder gegeven door te wijzen op de grotere investeringen in onderwijs door hoger opgeleiden en de groter ${ }^{*}$ opportunity cost" van het niet-werken voor hoger opgeleiden. Daarnalast laten opleidingsrichtingen waarin relatief veel mannen een opleiding heblsen gevolgd, zoals landbouw en techniek, een groter percentage werkenden dan gemiddeld zien. Het omgekeerde is het geval voor richtingen watrin relatief veel vrouven een opleiding hebben afgerond, zoals verzorging of dienstverlening en gezondheidszorg.

Voor het oplossen of verlichten van knelpunten op de arbeidsmarkt is het met name van belang om een indruk te krijgen van de mogelijkheden om het onbenutte arbeidsportentieel van werklozen en beschikbare niet-participerenden in te zetten in het arbeiclsproces. Uit tabel 4.5 blijkt dat deze twee groepen bij de lager opgeleiden (basivonderu'ijs en $V M B O$ ) qua onvang ongeveer gelijk zijn. Voor de hogere opleidingen is het a antal beschikbare niet-participerenden ongeveer de helfi van hel aantal werklozen. Onder de middelbare en hogere opleidingen zijn relatiel de meeste werklozen en beschikbare niet-participerenden te vinden in de opleidingscaltegorieën $\mathrm{MBO}$ dicmstverlening en gezondbeidszorg en wO tetteren en sociad-cultured. In het algemeen b) ijkt dat personen die een opleiding hebben gevolgd in het midkellatar of hoger onderwijs zich minder laten ontmoedigen dan personen met een lagere opleiding. Dexe ontmoediging kan ook veroorzalkt worden door de eerder genoemde verklatring dall lager opgeleiden een geringere stimulans hebben om te gatan werken, omdal de investering in hun opleiding lager is. Ook is al gewezen op het feil dall liger opgeteiden in het algemeen een lager loon verdenen. Wataderor hea vertichen van bijventhedel hushoudelijke taken relaticf alantrekkedijker is (i.e. ligere opportunity cost van nietwerken).

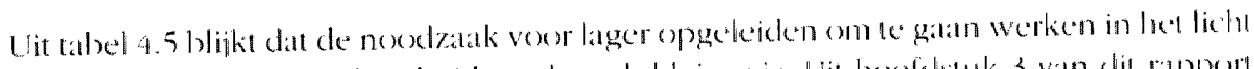
van de knelpunten op de arbeidsmarkt oxk kleiner is. lii hooldstuk i van dit rappont is in de tabel de typering valn de inclicator voor toekomstige knelpunten in de perser-

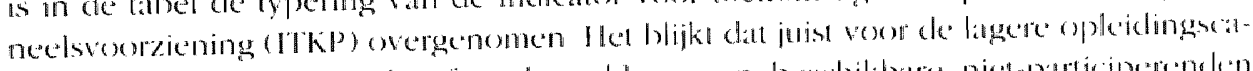

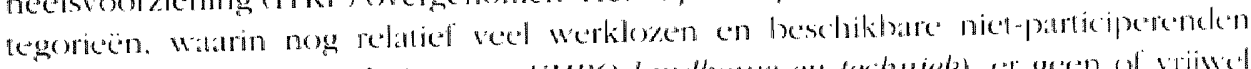

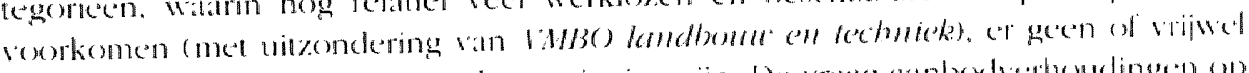

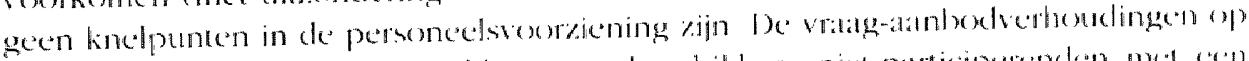

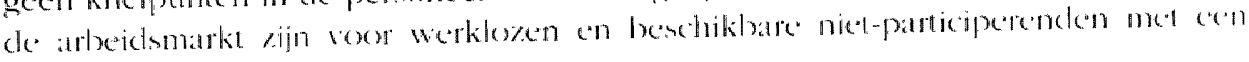

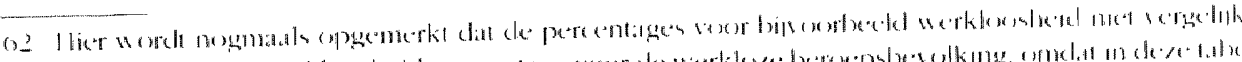

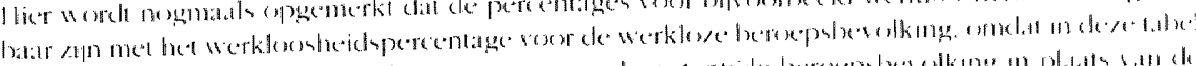

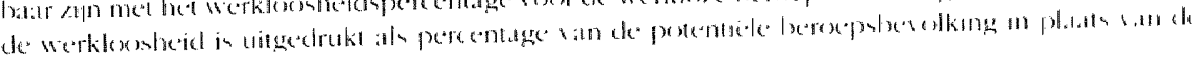

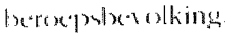


lagere opleiding geen stimulans om aan het werk te gaan. Naast de in het algemeen lagere bereidheid van personen met een lagere opleiding om te participeren, heeft dus ook de arbeidsmarkt een slechts geringe aanzuigende werking op deze personen om te gaan participeren.

Tabel 4.5

Arbeidsmarktpositie onbenutte arbeidspotentieel (exclusief scholieren en studenten) als percentage van de potentiële beroepsbevolking naar opleidingscategorie, gemiddelde 1998-1999

Opleidingscategorie

VMBO theorie

VMBO landbourw en techniek

VMBO economie

VMBO verzorging

HAVONWO

MBO landbouw en techniek

MB30 economie

MBO dienstver ening en gezondheidszorg

HBO landbouw en techniek

$\mathrm{HBO}$ economie

HBO onderwijs en socialit-cultureel

HBO paramedisch

wo landbouw en lechniek

Wo economie

Wo letteren en social-culturee

Wo medisch

Toual onbentl abeidspotentieel

BtoI: (BSS(B:BBS) / ROM(POA)
Werkloios Beschilkbaar

$\%$

$\%$

$\%$

Niet beschikbaar

Toekomstige knelpunten personeelsvoorziening (ITKP)

-

4

$3-2$

44

$4 \quad 4$

$5-3$

$2-1$

2

$3 \quad 3$

1 I

2

3

2

2

2

4

1

3

2 geen

vrijwel geen

geen

geen

geen

vrijwel geen

groot

groot

groot

groot

groot

groot

groot

zeer groot

zeer groot

grool

groot

\subsection{Concurrentiepositie van het onbenut arbeidspotentieel}

In de\%e paragratil wordt ingegaan op de vratag in welle mate het onbenut arbeidspo kntied door werkgevers ook als acceptabel atbeidsaanbod wordt gezien. Willen werk gever's weyklowen en herintreders ook diadwerkelijk in dienst nemen, of hebben zij eet sterke voorkeur voor het antrekken van schoolverlaters of mensen die reeds elder werkzaam zijn? Werligevers sekecteren nieuw personeel op basis van de verwacht geschilitheid voor de functie watrvor worde gerekruteed ${ }^{\text {th }}$. Ze houden datarbij teven rekening met versihillen in loonkosten en eventuele opleidingskosten die gemaak moxken worden wannect een bepatalde sollicitant wordt alangetrokken. De verwateht

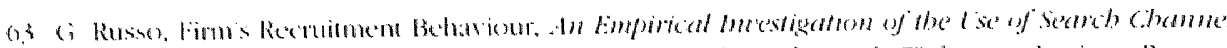

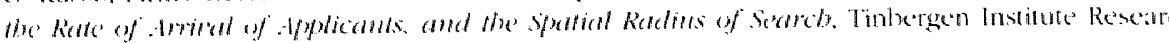

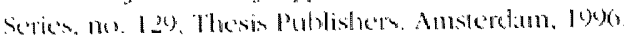


geschiktheid van een kandidaat is niet alleen afhankelijk van de vooropleiding van de kandidaten maar ook van de werkervaring ${ }^{6 \cdot 4}$. Veel kennis en vaardigheden kunnen zowel tijdens de opleiding als in de praktijk worden opgedaan. Daarnaast zijn er ook verschillende vaardigheden die vrijwel alleen maar in de praktijk kunnen worden verworven. Dat geldt met name voor sociaal-cognitieve vaardigheden zoals bijvoorbeeld leiding geven, het omgaan met collega's, het plannen en organiseren van het werk ${ }^{6 x}$. Bovendien kunnen mensen competenties na het verlaten van de opleiding weer (gedeeltelijk) verliezen wanneer deze lange tijd niet benut worden. Dit komt voor wanneer mensen enige tijd werkloos zijn, maar ook wanneer iemand lange tijd in een ander beroep werkzaam is dan waar hij of zij voor is opgeleid ${ }^{(\mathrm{s})}$. Scholingsveroudering treedt ook op als de inhoud van een beroep door technologische en/of organisatorische ontwikkelingen verandert.

Opleiding, werkervaring en (tijdelijke) inactiviteit zijn daarom belangrijke indicatoren voor de verwachte productiviteit van een kandidaat. Het belang van deze indicatoren zal echter verschillen tussen beroepen. In sommige beroepen zijn vaardighecten die tijdens de opleiding worden opgedaan van groot belang, denk daarbij bijvoorbeekl aan medische beroepen, zoals artsen. In andere beroepen is iemands opleidingsrichting van veel minder belang, omdat de belangrijkste vaardigheden voor deze beroepen juist in de praktijk worden opgedaan. Ook het gevaar van scholingsveroudering is niet in alle beroepen even groot. Met name voor beroepen die veel complexe kennis en varaligheden vereisen of waarin sprake is van snelle technologische veranderingen. zoals in veel IT-beroepen, is het belangrijk dat kennis en vaardigheden up to date worden gehouden.

Het relatieve belang van opleiding, werkervaring en inactiviteit voor een bepaakl beroep bepaalt voor een groot deel de concurrentiepositie van herintreders en werklozen in dat beroep ten opzichte van andere groepen op de arbeidsmarkt, zoals degenen clie reeds elders werkzaam zijn en schoolverlaters. Recente schoolverlaters heblen nog weinig last van scholingsveroudering mar hebben over het algemeen nauwelijks werkervaring. Reeds werkenden heblen wall valker clian schoolverlaters te malien meet scholingsveroudering, bijvoorbeck als ze lange lijd werkzatam zijn in een beroep buiten het eigen beroepsdomein. Daar stat tegenover dat $\%$ deor ervaring wel ved nicuwe kennis en vaardigheden hebben opgedaan. Herintreders en werklowen zijn korte of lange tijd inactief en een deel van hun kennis en vatardigheden zal daarom zijn verouderd. De mate van scholingsveroudering is in sterte mate allhankelijk valn de clutur van de inacriviteit" Herintreders en werklozen kunnen in het verlecken echler wel vect

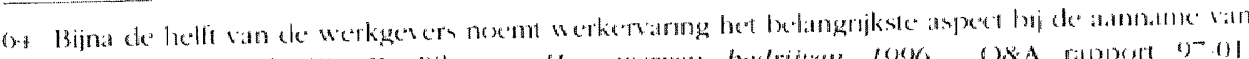

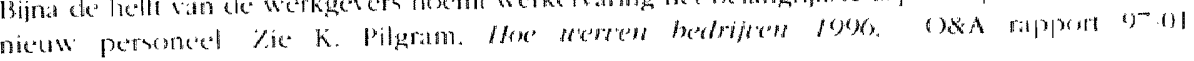

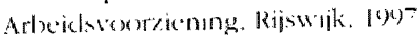

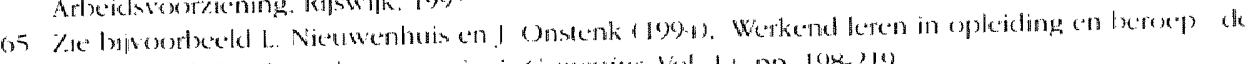

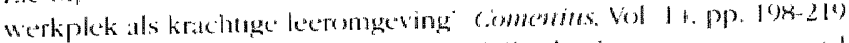

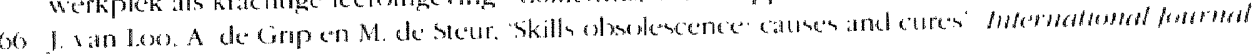

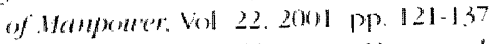

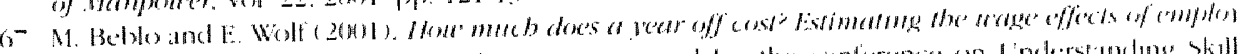

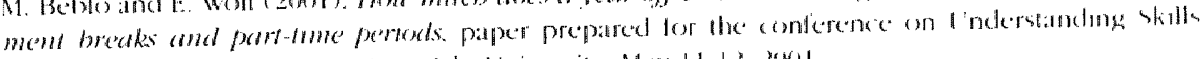

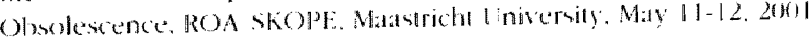


werkervaring hebben opgedaan. Op basis van deze werkervaring kunnen ze waarschijnlijk in beroepen waar weinig gevaar is voor scholingsveroudering, maar waar werkervaring van groot belang is, zoals bijvoorbeeld zorgheroepen, goed concurreren met schoolverlaters.

Howel er weinig reden is om aan te nemen dat werklozen meer last van scholingsveroudering hebben dan herintreders zullen werkgevers beide groepen toch niet als equivalent beschouwen. Met name in tijden van hoogconjunctuur is (langdurige) werkloosheid voor veel werkgevers een negatief signaal ${ }^{\left(x^{3}\right.}$. Als iemand er na een redelijke termijn nog niet in geslaagd is om een baan te vinden, is hij of zij, in de ogen van de werkgever, waarschijnlijk ook minder capabel.

De concurrentiepositie van herintreders en werklozen ten opzichte van andere alanbieders is eveneens afhankelijk van de schatarste op de arbeidsmarkt. Werkgevers kunnen weliswar een sterke voorkeur hebben voor werkende kandidaten met een goed alansluitende opleiding en veel werkervaring; als deze kandidaten niet voorhanden zijn zullen ze toch moeten zoeken naar alternatieven. Winden en Van Nes hebben onderzoek gedaan naar werkgeversreacties op een krappe arbeidsmarkt in de periode van 1995 tot $1999^{\left(x^{*}\right)}$. Uit het onderzoek blijkt dat de oorzaak van moeilijk vervulbare vacatures steeds vaker een kwantitatief tekort aan kandlidaten is, clat wil zeggen er reageren gewoon te weinig kandidaten. Bedrijven die vacatures niet vervuld krijgen, kunnen het aantal bedriffsactiviteiten verminderen. dle werkdruk van zittend personeel verhogen. zittend personeel omscholen of de selectiecriteria voor nieuwkomers verrumen eventueel in combinatie met alanvullende scholing. Het blijkt dat tussen 1995 en 1999 opleidingeisen voor nieuwkomers inderdaad steeds minder belangrijk zijn geworden. In plaats daarvan kijken werkgevers met name natar de leergierigheid van kandidaten. Bovendlien blijkt dat bedrijven die daadwerkelijk knelpunten ondervinden bij het vervullen van vacatures vaker de eisen die ze stellen aan nieuw personeel verrumen en vaker nieuw personeel zelf opleiden. Door cle krappe arbeidsmarkt zien werkgevers herintreders steeds valker als potentiè le kandiclaten voor een functic.

\section{Werkgeversvoorkeuren}

Om inziche $1 e^{2}$ krijgen in cle werkgeverswoorkeuren kan worden gekeken natar cke concurrentic|positie van herintreders en werkikzen ten oprichte van degenen die reeds werkzatam zijn en sehomberlalers in cen drietal bedrifssectoren, namelijk de IT: de

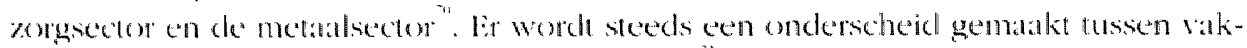

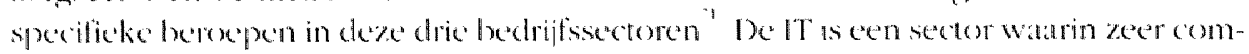

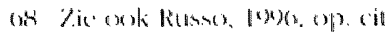

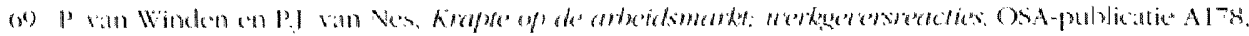
$2(x) 1$

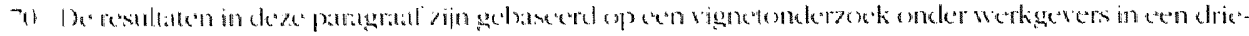

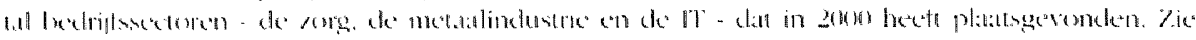

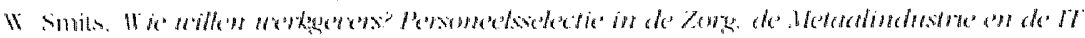

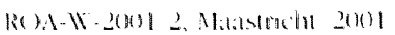

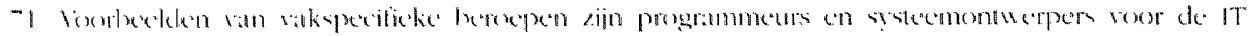

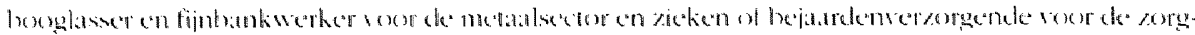

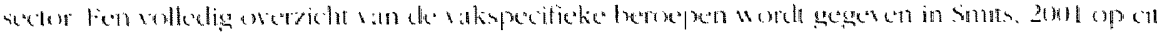


plexe vaardigheden vereist worden die bovendien door de snelle technologische ontwikkelingen snel weer verouderen. De relatie tussen opleiding en beroep is in deze sector relatief zwak ${ }^{2}$. De laatste jaren ondervindt de IT-branche grote knelpunten in de personeelsvoorziening. De zorgsector is een zeer arbeidsintensieve sector, watr scholingveroudering veel minder een rol speelt maar waar daarentegen de formele opleidingseisen voor de verschillende functies zeer belangrijk zijn. Ook in de zorgsector zijn de knelpunten de laatste jaren sterk toegenomen ". Verder word de zorgsector getypeerd door het hoge percentage vrouwen dat in de sector werkzaam is. In de metaal is het percentage vrouwen daarentegen zeer laag. In tegenstelling tot beide overige sectoren is de werkgelegenheid in de metaal zeer conjuncturgevoelig. Verwacht mag worden dat genoemde sectorkenmerken ook tot uiting komen in de werkgeversvoorkeuren met betrekking tot personeel voor verschillende functies.

Korte of langdurige inactiviteil kan, zoals gezegd, tor scholingsveroudering leiden. Daarom mag verwacht worden dat herintreders en werklozen in veel functies mincler productief zijn dan werkenden en dat bij- of herscholing voor deze groep vaak noxdzakelijk is. In welke mate concurreren kandidaten zonder baan met kandidaten die al een baan hebben, en is er daarbij een verschil tussen iemand die werkloos is en iemand die huisvrouw of -man is? In tabel 4.6 worden kandidaten die korte of lange tijd inactice zijn geweest vergeleken met werkende kandidaten die verder dezelfde vooropleiding en werkervaring hebben. Uit de tabel blijkt dat voor de vakspecitieke beroepen in de metaal, de IT en de zorgsector, kortdurige werkloosheid er niet zoveel toe doet. Langdurige werkloosheid verkleint echter de kans dat iemand word aangetrokken wel aanzienlijk. Gemiddeld is de kans dat iemand die langdurig werkloos is word verkozen boven iemand met een baan 35\%, hetgeen significant lager is dan $50 \%$. In de zorgsector is deze kans wat groter en in de IT wat lager, maar de verschillen tussen de drie bedrijfssectoren zijn minimal.

Tabel 4.6 laat verder zien dat in de IT iemand die korte tijd huisvrouw of -man is geweest een kleinere kans heeft on te worden verkozen dan kandidaten die korte tijd werkloos zijn geweest. Voor degenen dic lange tijd huisvrouw zijn geweest is er in de IT geen verschil me kandidaten die lang werkloos zijn geweest. In cle zorgsector hebben kandidaten die lange tijd huisvrouw zijn geweest datantegen de voorkeal boven kandidaten die lang werkloos zijn geweest. Men is hier veed meer gewend te werkien met herintreders. omdat er in deze sector veel vrouwen gijn dic valak vour lange lijel stoppen met werken om voor de kinderen te zorgen en weer aan de slig willen als de kinderen wat groter zijn Bovendien speelt hier scholingsverestedering e'en munder belangrijke rol, zodal herintreders relaticel makkedijk weer aton de slag kunmen in de metala is er geen verschil tussen herintreckers en werklowen.

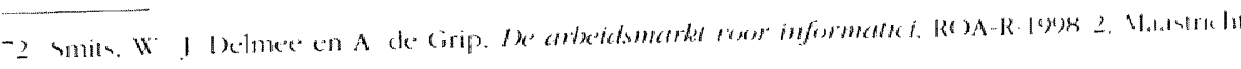
1948

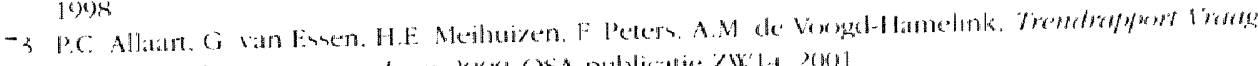

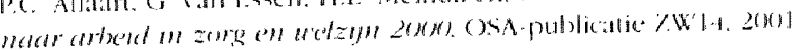




$\begin{array}{lrrr} & \text { IT } & \text { Zorg } & \text { Metaal } \\ & \% & \% & \% \\ \text { Korter dan I jaar werkloos } & \% & & 49 \\ \text { Langer dan I jaar werkJoos } & 43 & 54 & 35 \\ \text { Korter daun I jaar huiswrouw/man } & 32 & 38 & 44 \\ \text { Langer dan I jaar huisvrouw/man } & 28 & 41 & 36\end{array}$

- Als de kans gelijk is tan $50 \%$, dan hebben werkgevers geen voorkeur voor een werkloze of herintreder ten opzichte van een werkende.

Bron: ROA(Vignetonderzoek)

Werkgevers hebben voor de meeste beroepen een duidelijke voorkeur voor werkenden boven herintreders en langdurig werklozen. Scholingsveroudering speelt deze laatste twee groepen dus inderdaad parten. Kortdurig werklozen kunnen daarentegen beter concurreren met werkenden.

Werklozen en herintreders concurreren echter niet alleen met reeds werkende kandidaten, maar ook met schoolverlaters. Schoolverlaters hebben geen last van scholingsveroudering, maar hebben meestal erg weinig ervaring. Een herintreder of werkloze kandidaat die in het verleden veel relevante werkervaring heeft opgedaan, kan daarom in sommige beroepen een meer aantrekkelijke kandidaar zijn dan een schoolverlater.

"iabel 4.7

De kans dat werklozen en herintreders met relevante werkervaring worden verkozen boven een tien jaar jongere schoolverlater*

\begin{tabular}{|c|c|c|c|}
\hline & $\begin{array}{l}\text { IT } \\
\%\end{array}$ & $\begin{array}{r}\text { Zorg } \\
\%\end{array}$ & $\begin{array}{r}\text { Metaal } \\
\%\end{array}$ \\
\hline Korter diun l fatilr werkikloos & 80 & 62 & 84 \\
\hline L.anger diun 1 jatar werkloos & 71 & 46 & 75 \\
\hline Korter denn I jutur huisvrouw/man & 67 & 49 & 81 \\
\hline I.anger dian I jaur huisvrouw/man & 74 & 55 & 76 \\
\hline
\end{tabular}

* Als de kans gelijk is atu $50 \%$, diun lebben werkgevers geen voorkeur voor een werkloze of herintreder ten opzichte vin wen schoolverlater.

Bron: RoA(Vignetonderoelk)

'lahble 4.7 geeft een beekl van de kins dat een herintreder of werkloze met retevante werkervaring word verkozen boven een tien jata jongere schoolverlater met dezelfde

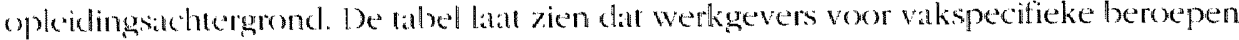
in de me:iat en de IT een duidetijke voorkeur hebben voor werklozen of herintreclers mel vere relevante werkentaring boven een schoolverlater. Met name voor de IT is dit opmenkelijk, omdat dit cen sector is wiar, door de snelle technologische ontwikkelingen. hel risico van scholingsveroudering erg groot is. In de zorgsector zijn de voorkeuren veel minder sterk. Werkgevers hebben wel een voorkeur voor korturig werklozen 
met veel relevante werkervaring boven schoolverlaters maar zijn indifferent tussen langdurig werklozen en herintreders of schoolverlaters.

Tabel 4.8

De kans dat werklozen en herintreders met een goed aansluitende opleiding en relevante werkervaring worden verkozen boven een tien jaar jongere schoolverlater met een niet goed aansluitende opleiding*

\begin{tabular}{|c|c|c|}
\hline & $\begin{array}{r}\text { Zorg } \\
\%\end{array}$ & $\begin{array}{r}\text { Metaal } \\
\%\end{array}$ \\
\hline Korter dan 1 jaar werkloos & 84 & 86 \\
\hline Langer dan 1 jaar werkloos & 72 & 77 \\
\hline Korter dan 1 jaar huisvrouw/man & 73 & 83 \\
\hline Langer dan 1 jaar huisvrouw/man & 80 & 78 \\
\hline
\end{tabular}

Bron: ROA(Vignetonderzoek)

De positie van herintreders en werklozen word nog beter indien ze concurreren met schoolverlaters met een minder goed aansluitende opleiding. Tabel 4.8 laat zien dat in dat geval ook in de vakspecifieke beroepen van de zorgsector een sterke voorkeur is voor werklozen en herintreders boven schoolverlaters.

Tabel 4.9

De kans dat werklozen en herintreders zonder relevante werkervaring worden verkozen boven een vijf jaar jongere schoolverlater met een gelijke opleiding*

Konter dan 1 jaar werkloos

Langer dan 1 jaar werkloos

Korter dan 1 jaar huisurouw/man

Langer dan 1 jaar huisvrouw/man

$\begin{array}{rrr}\text { IT } & \text { Zorg } & \text { Metaal } \\ \% & \% & \% \\ & & \\ 46 & 42 & 58 \\ 34 & 27 & 43 \\ 30 & 30 & 52 \\ 38 & 35 & 45\end{array}$

* Als de kans gelijk is aan 50\%, dan hebben werkgevers geen woorkeur wor wen werkloze of herintreder ten opzachite vim een schoolverlater.

Bron: ROA(Vignetonderzoek)

Ten slotte bekijken we de concurrentiepositie van herintreders en werkloze kandidatten die in het verkeden geen relevante werkervaring hebhen opgedaan Taled 4.9 lital zien dat in de meeste beroepen kortdurig werklozen zonder ervaring redelijk kunnen concurreren met schoolverlaters. Langdurig werklozen en herintreders die geen rede werkervaring heblyen, hebben met name in de tT en de zorgaector ecen cry sledate oncurrentiepositie ten opzichte van schoolvetlaters. 


\section{Knelpunten en selectiecriteria}

In het bovenstaande werd ingegaan op de voorkeuren van werkgevers. Deze voorkeuren bepalen voor een belangrijk deel of een kandidaat acceptabel is voor een functie. Echter, werkgevers kunnen wel sterk de voorkeur hebben voor kandidaten met een aansluitende opleiding en vijf jaar werkervaring, maar wat doen ze als deze kandidaten niet voorhanden zijn? Met andere woorden, passen werkgevers de selectiecriteria aan onder invloed van de arbeidsmarktsituatie? Om dit na te gaan is eerst gekeken of bedrijven die daadwerkelijk knelpunten in de personeelsvoorziening ondervinden een kandidaat eerder acceptabel vinden voor een functie. Daarnaast is gekeken of de gemiddelde kwaliteit van potentièle kandiclaten voor een functie van invloed is op de kans dat iemand acceptabel word gevonden. Als blijkt dat werkgevers minder streng gaan selecteren naamate de kwaliteit van de kandidaten lager is, kan geconcludeerd worden dat de selectiecriteria duidelijk aan de arbeidsmarktsituatie worden angepast.

Tabel 4.10

Het effect van knelpunten in de personeelsvoorziening en de kwaliteit van het arbeidsaanbod op de selectiecriterla

loename knelpunten

Niname kwaliteit arbeidsaanbod
IT

minder streng

minder streng
Zorg

geen effect minder streng

strenger minder streng

Bron: ROA(Vignetonderzoek)

Uit tabel 4.10 blijkt dat werkgevers in de IT en de metal minder streng gaan selecteren als ze moeilijkheden hebben om vacalures te vervullen. In de zorgsector wordt geen significant effect gevonden van knelpunten in de personeelsvooziening. Verder blijkı dat in de l't" en de metaal de kitns dat een kandidatal atceptabel wordt gevonden voor cen functice, roeneemt nairmate de gemiddelde kwaliteil van de sollicitanten lager is. bit betekent dat de selectiecriteria worden verrumel als de kwaliteit van hel atrbeids-

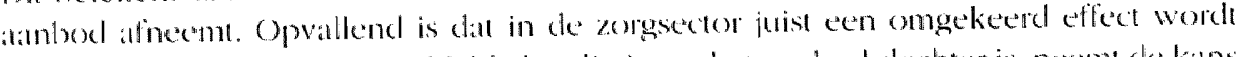
gevonden Natarmate de gemiddelde kwalliteit vatn het atanbod slechter is, neemt de kans

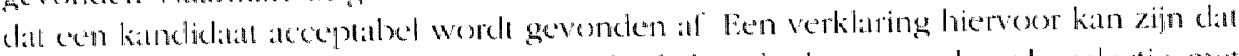

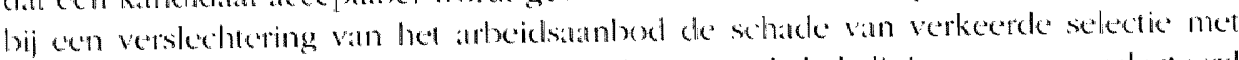

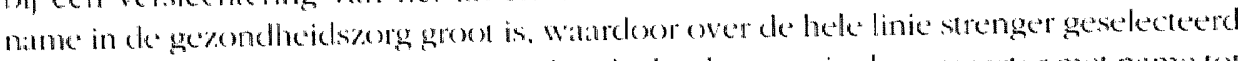

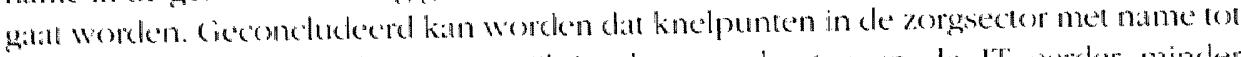

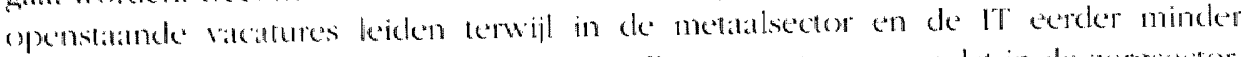
geschikte kandidaten worden atmgenomen. Datr statt tegenover dat in de zorgsector. herint reckers met een geschikte vooropleiding en relevante ervaring. beter kunnen concurreren met reeds werkende kiandidaten. hetgeen de kims op knelpunten juist verkileint.

\subsection{Het onbenutte arbeidspotentieel in de IT-, zorg- en metaalsector}

Als vervelg op de analyse over de concutentiepositic van werklozen en he rintreders in 
de IT-, zorg- en metaalsector wordt in deze paragraal nagegaan hoe groot het onbenutte arbeidspotentieel in deze sectoren is. Voor het opsporen van het onbenutte arbeidspotentieel voor deze sectoren is gekeken naar de werklozen en niet-participerenden die een voor de sector geschikte opleiding of passende werkervaring hebben. In de vorige paragraaf werd duidelijk dat werklozen en niet-participerenden op de arbeidsmarkt concurrerend kunnen zijn ten opzichte van schoolverlaters als ze een sectorspecifiekte opleiding hebben en gedurende hun werkzame arbeidsleven voor de sector relevante werkervaring hebben opgedaan. Deze factoren worden door werkgevers zo belangrijk geacht dat bij knelpunten in de personeelsvoorziening werklozen en niet-participerenden met een voor de sector relevante opleidings- en ervaringsachtergrond een goede kans op betaald werk maken.

\section{Geschikte opleiding}

In tabel 4.11 zijn de belangrijkste opleidingstypen in de IT-, zorg-en metaalsector weergegeven. Deze opleidingstypen zijn geselecteerd op basis van de mate watrin ze vor komen in de betreffende sectoren, met name in de beroepen watrdoor deze sectoren gekenmerkt worden ".

Tabel 4.11

\section{Belangrijkste opleidingstypen in de IT-, zorg- en metaalsector}

\section{IT}

MBO automatisering, MBO electrotechniek, $\mathrm{HBO}$ electrotechniek, $\mathrm{HBO}$ informatica, WO wiskunde en natuurwetenschappen, wo informatica en bestuurlijke informatiekunde

\section{Zorg}

VMBO (uiterlijke) verzorging, MBO dokters-, tandarts- en dierenartsassistent, MBO apothekersassistent, MBO verpleging, MBO gezondheidstechniek, MBO verzorging, MBO uiterlijke verzorging, MBO beweging en therapie, HBO verpleegkunde, HBO (frsio) therapie, HBO voeding, $H B O$ radiologie, $H B O$ paramedisch overig, wO (dier)geneeskunde, wO tandheellkunde, Wo farmacie en medische biologie

\section{Metaal}

VMBO meteal: (fijn)mechanische techniek. MBO werktuighouw en mechaniscle techniek. MBO fijnmechatnische tech niek. $\mathrm{HBO}$ werktuigbouwkunde, WO werktuighouwkunde

\section{Bron: ROA(POA)}

In de bersepen van de betreffende sectoren. en zeker in de meer algemene beroepen. kunnen echter ook mensen met een anckere opleidingsidetergend werksatam zijn.

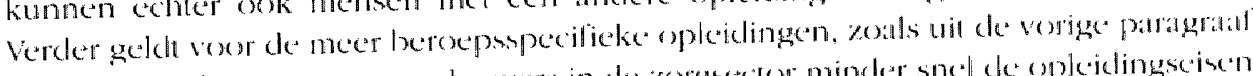
is gebleken, dat met name werkgevers in de zorgsecter minder snel de oppledelingscisen

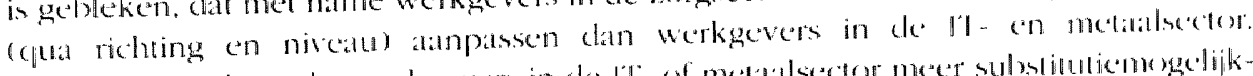

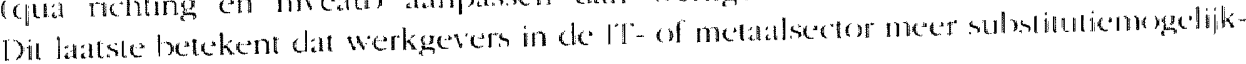
heden hebloen clan werkgevers in de zorgsector.

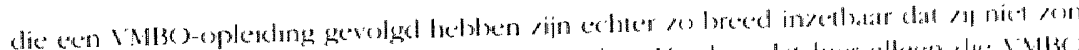

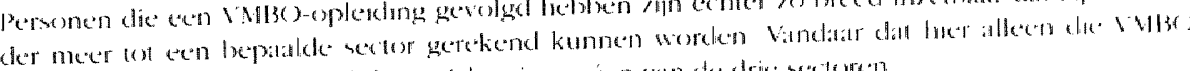

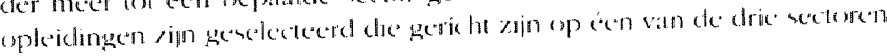


Tabel 4.12

Aandeel werklozen en niet-participerenden in de potentiële beroepsbevolking (exclusief studenten en scholleren) voor drie sectoren, naar opleidingsniveau, gemiddelde 1998-1999

Sector Oplleidings:
niveau

IT

\begin{tabular}{|c|c|c|c|c|}
\hline & MBO & 2 & 8 & 221.500 \\
\hline & $\mathrm{HBO}$ & 2 & 7 & 94.000 \\
\hline & Wo & 3 & 8 & 90.500 \\
\hline & 'Totaal & 2 & 8 & 406.000 \\
\hline \multicolumn{5}{|l|}{ Zorg } \\
\hline & VMBO & 8 & 59 & 530.500 \\
\hline & MBO & 6 & 32 & 782.000 \\
\hline & $\mathrm{HBO}$ & 3 & 14 & 153.500 \\
\hline & Wo & 1 & 6 & 68.500 \\
\hline & Totanl & 6 & 38 & 1.534 .500 \\
\hline \multicolumn{5}{|l|}{ Metaal } \\
\hline & $\mathrm{VMBO}$ & 5 & 14 & 147.000 \\
\hline & MBO & 2 & 12 & 175.000 \\
\hline & $\mathbb{H B O}$ & 1 & 10 & 42.500 \\
\hline & WO & 2 & 4 & 13.500 \\
\hline & Totaal & 3 & 12 & 378.000 \\
\hline
\end{tabular}

Bron: CBS(EBB, SEP) / ROA $(\mathrm{POA})$

In tabel 4.12 is weergegeven hoe groot het andeel van het onbenutte arbeidspotentieel in de potentiële beroepsbevolking is voor de sectorspecifieke opleidingstypen van elk van de dric sectoren. Datalbij word onderscheid gemaakt tussen de opleidingsniveau's van enerzijds de werklozen en de beschikbare niet-participerenden en anderzijds de nict-participerenden die niet beschikbatar voor de arbeidsmarki zijn. Llit de tabel blijkt dat op alle opleidingsnivealus het andeel van de niet-beschikbare personen van de

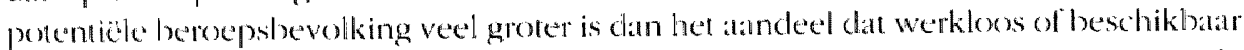
is. Zoals in paragrala 4.2 duidelijk werd, aijn degenen die niet beschikbatar zijn voor de atheidsmark mensen die niet willen werken, matr on mensen die niet op korte lemijn beschikhatur zijn, arbeidsongeschikt zijn of met pensioen zijn. Met name bij opleidingen voor de zorgsector op $\mathrm{VMBO}$ - en MBO-niveal is het alandeel wan de\% mensen erg hoog (respectievelijk $59 \%$ en $32 \%$ ) hetgeen woor belangrijk cleel zijn oorzatak vind in het traditioneel grote abudeel trouwen met een zorgopleiding.

Mel witzomelering van de VMBO-opleidingen voor de zorg- en metalsector en de MBOopleidingen voor de zorgsecor, is hed percentage werklowen en beschikbare niet-participerende persenen rin de potentie le beropstrevolking voor de andere opleidingsniveaus nergens groter dan $3 \%$. Bij de HBO-opleidingen gerich op de metalisector en de Wo-opkedingen geticht op de zorgsector is het percentage werklozen en beschikbare nict participerenden slechts $1 \%$. 
In tabel 4.13 wordt het aantal werklozen en niet-participerenden afgezet tegen het verwachte vraagoverschot in 2006 voor elk van de drie sectoren. Met name in de zorgsector, maar ook in de metaalsector blijkt het potentieel arbeidsaanbod dat beschikt over een sectorspecifieke opleiding voldoende groot om in de verwachte personeelstekorten te kunnen voorzien. Daarvoor is het noodzakelijk dat voor de zorgsector ruim $20 \%$ en voor de metaalsector bijna $60 \%$ van het onbenutte arbeidspotentieel weer in de betreffende sector instroomt. Bij deze confrontatie van het potentiële arbeidsaanbod en het verwachte vraagoverschot wordt echter geen rekening gehouden met de kwalitatieve discrepanties. Zo bestaat het onbenutte arbeidspotentieel van de zorg- en metaalsector voor een belangrijk deel uit personen met een VMBO-opleiding (tabel 4.12), waarvoor geen vraagoverschot wordt verwacht (zie paragraf 3.2 )"

Tabel 4.13

Aantal werklozen en niet-participerenden met een geschikte opleiding maar zonder relevante werkervaring in relatie tot het verwachte vraagoverschot in de IT-, zorg- en metaalsector, gemiddelde 1998-1999

Sector

IT

Zorg

Metalal
Werkloos of niet-participerend Inclusief niet-

beschikbare

personen

40.000

681.500

58.500
Exclusief niet-

beschlkbare

personen

8.500

95.000

12.000

\section{Indicatie \\ vraagoverschot in \\ 2006}

32.000

20.000

7.000

Bron: CBS(EBB, SEP) / ROA(POA)

\section{Relevante werkervaring}

Van het onbenutte arbeidspotenticel dat een sectorspecifieke opleidingsachtergrond heett, zijn met name de personen interessint die ook herocpsspecifieke werkervatsing hebben opgedaan. Uit de vorige paraglatif is gebleken diall de\% personen voor ved werkgevers atantrekkelijker zijn dan schoolverlaters, en dan de relevante werkervaring die schoolverlaters nu eenmalal meestal missen databij een belangrijke lactor is. In laluel 4.14 is angegeven in welke beroepsgroepen de relevante werkervaring door werklozen en niet-participerenden gedurende hun werkzame arlocidsleven kin zijn opgedatan.

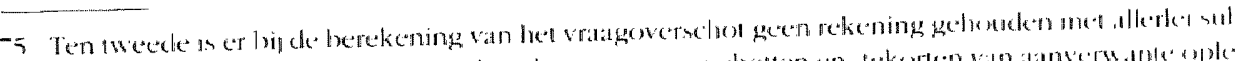

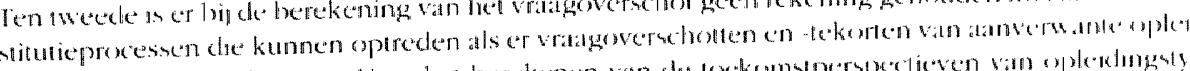

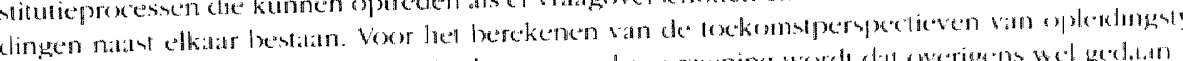

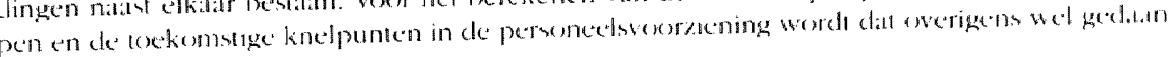


Tabel 4.14

Beroepsgroepen in de IT-, zorg- en metaalsector waar werklozen en herintreders relevante werkervaring kunnen hebben opgedaan

Metaal

Metalarbeider, Bankwerker en lasser, Monteur, Bedriffshoofd metaallbewerking Materiaalkundige

\section{Zorg}

Verpleeghulp en leerling-verpleegkundige, Verplegende en doktersassistent, Apothekersassistent en medisch laborant, Medisch secretaresse, Ziekenverzorgende, Therapeut en verpleegkundige, Afdelingshoofd zorginstelling

\section{IT}

Programmeur; Systeemanalist

Bron: ROA(PON)

Tabel 4.15 geeft het aantal werklozen en niel-participerenden weer met een geschikte opleiding én relevante werkervaring in één van de drie sectoren ${ }^{-6}$. Het blijkt dat er voor de IT-sector nauwelijks onbenut arbeidspotentieel is met een geschikte opleiding en relevante werkervalring. Voor de zorg- en de metalsector lijkt er in eerste instantie genoeg potentieel alanbod te zijn van werklozen en niet-participerenden om te voldoen atan het verwachte vraagoverschot in 2006 . Verreweg het grootste deel van dit onbenutte arbeidspotentieet is echter niet beschikbaar voor de arbeidsmarkt . De inzet van werklozen en niet-participerenden die wel beschikbaar voor de arbeidsmarkt zijn, zal voor ruim een derde kunnen bijdragen aan het verminderen van het verwachte vraagoverschot in 2006 in de zorgsector. In de metalsector is dat voor ongeveer de helft ${ }^{-x}$.

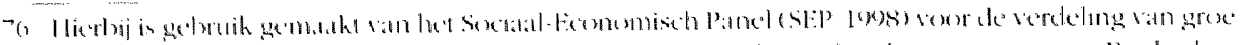

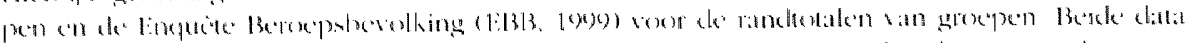

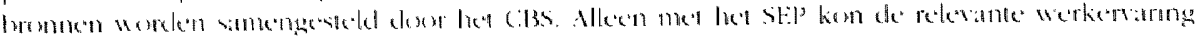

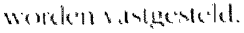

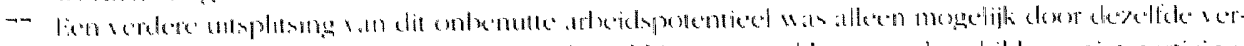

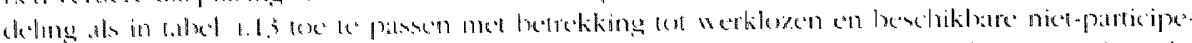

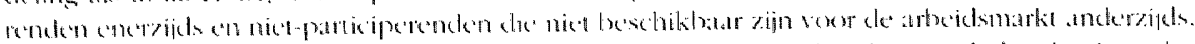

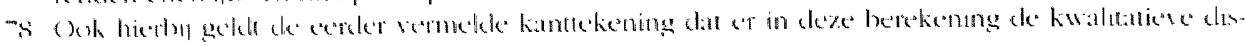

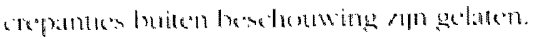


Tabel 4.15

Aantal werklozen en niet-participerenden met een geschikte opleiding én relevante werkervaring in relatie tot het verwachte vraagoverschot in de IT-, zorg- en metaalsector, gemiddelde 1998-1999

Sector

Werkloos of niet-participerend Inclusief niet- Exclusief niet-

beschikbare beschikbare

personen

IT

Zorg

Metaal
54.000

16.500
Indicatie

vraagoverschot in

2006

32.000

20.000

7.000

Bron: CBS(EBB, SEP) / ROA(POA) 


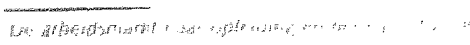




\section{De aanhoudende krapte op de arbeidsmarkt}

Uit voorgaande hoofdstukken van dit rapport komt naar voren dat voor de periode 2001-2006 de krapte op de arbeidsmarkt zal blijven aanhouden, ondanks de verwachte minder sterke economische groei. Dit betekent enerzijds dat schoolverlaters met een middelbare beroepsopleiding, een hogere beroepsopleiding of een universitaire opleiding over het algemeen goede vooruitzichten hebben op een baan die aansluit bij hun opleiding. Anderzijds zal het voor werkgevers op veel segmenten van de arbeidsmarkt moeilijk blijven voldoende personeel te vinden met minimal een middelbare beroepsopleiding in de gewenste richting.

Tabel 5.1 laat zien dat $40 \%$ van de schoolverlaters een opleidingsachtergrond hebben waarvoor werkgevers grote tot zeer grote knelpunten in de personeelswerving ervaren. Het gaat hier met name om schoolverlaters met minimaal een middelbare beroepsopleiding. Als werkgevers nieuw personeel moeten aantrekken omdat de werkzalamleden toenemen of omdat er personeel uitstroomt, zal het voor hen moeilijk zijn schoolverlaters met een dergelijke opleidingsachtergrond te vinden. De consequenties daturvan kunnen velerlei zijn. Werkgevers kunnen trachten schoolverlaters met een opleidlingsachtergrond waarvoor minder grote knelpunten bestaan, nog altijd de hellt van de totale arbeidsmarktinstroom van schoolverlaters, te rekruteren en hen om of bij te scholen. Deze schoolverlaters zijn voor een groot deel ongeschoolden ('drop outs") en gediplomeerden van het VMBO en het HAVO/VWO.

In dit verband dient er op gewezen te worden dat de totale instroom van schoolverlaters op de arbeidsmarkt als percentage van de werkgelegenheid naar verwachting datalt (zie hoofdstuk 1). Met name voor de hoger opgeleiden van zowel het HBO als het WO. zo bleek in hoofdstuk 2, houdt de arbeidsmarktinstroom geen gelijke tred met de werkgelegenheidsgroei. Het verwachte gemiddelde aantal HBO-ers dat op de arbeidsmarkt instroomt, blift met ongeverer 58.000 personen per jaar gelijk. Datarentegen datall thet alantal WO-ers dat tot de arbeidsmarkt toetreed van ongeveer $30.0(0)$ per jatal in de periode 1996-2000 naar rum 26.000 afgestudeerden gemideleld per jaar in periocke 2001-2006. Toch zullen er ook schoolverlaters met een middellyarc of hogere I xere expopleiding zijn die genoodzaakt worden buiten hun vakrichting of onder hum nivean ic gatan werken vanwege de minder goede perspectieven van hun opleicling op de arbeidsmarkt. De minder goede perspectieven voror deze schoolverlaters zullen edolet slechts in beperkte mate in werklonsheid resulteren. pere schoolvertaters kunnen immers in de vratagledoethe vourzien op andere arberdsmarktsegmenten vanwege de substitutiemogelijkheden die er voor werkgevers bestatan lussen personen med een ver-

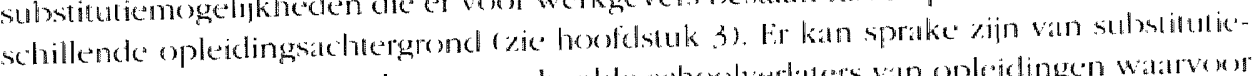
vraag natar middelbare en hoger geschookle schoolvetaters van opleidingen watrox er een alinbodoverschot is. Deze schoolverlaters werden dan angeltokken op funders in een andere vakrichting of op een lager beroepsniveatu.

1)aarnalst kunnen werkgevers putten uil een reservoir van werklowen en nico-participerenden. Van dit onbenute arbeidspotentieed wan ruim 2.8 miljexn personen is exther

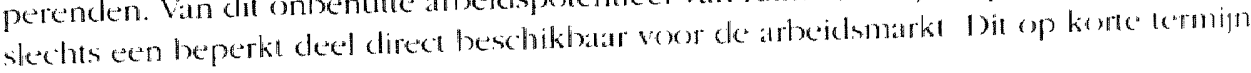


voor de arbeidsmarkt beschilklbare onbenutte arbeidspotentieel is de laatste jaren namelijk vanwege de aanhoudende grote krapte op de arbeidsmarkt aanzienlijk geslonken. Het alandeel van deze groep in het totale onbenutre arbeidspotentieel is gedaald van $25 \%$ in 1994 nat $17 \%$ in 1999 . Bovendien blijkt uit tabel 5.1 dat slechts eenderde deel van de werklozen en iets meer clan eenvijfde deel van de niet-participerenden een opleidingsachtergrond heeft waar werkgevers behoefte an hebben. In totaal gaat het hier nat schatting om ongeveer 125.000 personen". Het grootste deel van de werklozen en beschikbare niet-participerenden dient echter eerst om- of bijgeschoold te worden om voldoende productief te kunnen zijn. Hun aantal bedraagt ruim 300.000 personen.

Tabel 5.1

Percentage van de schoolverlaters en de potentiële beroepsbevolking waarvoor werkgevers naar verwachting met (vrijwel) geen of julst (zeer) grote knelpunten in de personeelsvoorziening zullen worden geconfronteerd in 2006

\begin{tabular}{|c|c|c|}
\hline & $\begin{array}{r}\text { (vrijwel) geen } \\
\text { knelpunten } \\
\%\end{array}$ & $\begin{array}{r}\text { (zeer) grote } \\
\text { knelpunten } \\
\%\end{array}$ \\
\hline Schoolverlater & 50 & 40 \\
\hline Werkzatan & 42 & 48 \\
\hline Werkloos & 61 & 33 \\
\hline Beschikbutar & 71 & 22 \\
\hline Niet-heschikbatal & 72 & 23 \\
\hline Totalal (excl. schoolver: thers) & 50 & 41 \\
\hline
\end{tabular}

Bron: ROA(POA)

Uit tabel 5.1 blijkt verder clat bijna de helft van de werkzame bevolking (ruim 3 miljoen mensen) (en opleidingsachtergrond heeti waarvoor in de periode $2001-2006$ grote knclpunten in de personeelsvoorziening worden verwacht. Indien hun werkgelegenheid lexneemt of indien ar uitstroom van dit personed platsvindt. terwijl de werkgever er onvoldoende in silatgl nieuw personect atan te trekken, kan dall als gevolg hetbben dill het ziltende personeel moel overwerken of onder grote werkelruk moet fincbioncren Andere gevolgen kunnen zijn een verlaging van de kwaliteil van de verrichte

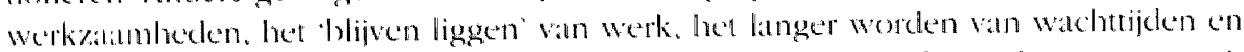
wathelijsten, het ontstan van productie- en omeaverlies, of zells het sluten van vestigingen of het overplatitsen van deze vestigingen natr het buitenland.

In voomgatande hootelstuklien is ingegatan opeen anantal belangrijke ontwiklielingen die sitmenhangen met de kraple op de ableidsmarkt. Deze ontwikkelingen an zowel de vratig-als cle atabxelizijke van cle arbeidsmarkt, zullen hieronder nader worden belicht.

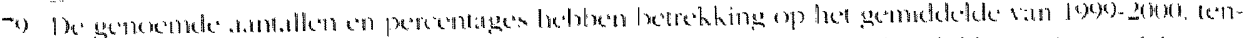

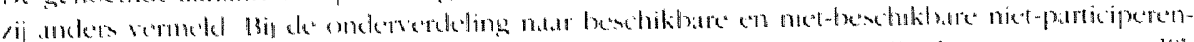

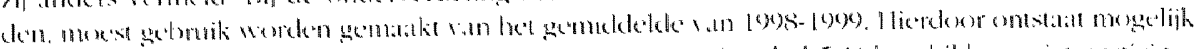

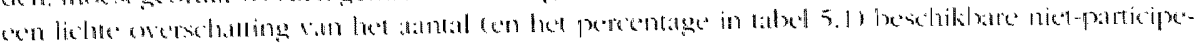
nemente 


\section{Besproken worden:}

- de snelheid van het upgradingsproces;

- de kenmerken van het personeelsbestand in beroepsklassen;

- de arbeidsomstandigheden en uitstroom van de arbeidsmarkt;

- de instroom van voortijdig schoolverlaters op de arbeidsmarkt:

- de arbeidsmarktinstroom vanuit het post-initieel onderwijs.

\section{Snelheid van het upgradingsproces}

Eén van de belangrijke oorzaken van het tekort aan hoger opgeleiden is de upgrading van de opleidingseisen in veel beroepsgroepen. Hierdoor stijgt de vraag natr hoger en middelbaar opgeleiden ten koste van degenen mel een middelbare respectievelijk lagere opleiding. De verschuiving in de verwachte werkgelegenheidsontwikkeling voor de verschillende opleidingsniveaus die hieruit resulteent, is in hoofdstuk 1 weergegeven door middel van het 'opleidingseffect, Uit scenario-analyses" en een door het ROA uitgevoerde gevoeligheidsanalyse voor het Centraal Economisch Plan $2000^{* 2}$ blijk dal de snelheid van het upgradingsproces van grote invloed is op de uitbreidingsvratag en de mede daaruit resulterende knelpunten op de arbeidsmarkt. Het is van groot belang om de toekomstige upgradingssnelheid van de kwalificatie-eisen binnen cke verschillende beroepsgroepen, dat wil zeggen de snelheid watarnee het opleidingsniveall van de Nederlandse werkgelegenheid stijgt, goed in te schatten vanwege de grole invloxt ervan op de toekomstige arbeidsmarktperspectieven voor hoger en lager opgeleiden.

Zoals in hooldstuk 1 werd aangegeven wordt de snelleid van het upgradingssnetheidproces mer name bepaald door de diffusie van technologische vernieuwingen en cle mede daaraan gerelateerde organisatorische veranderingen. In een recente studie van het ROA is geprobeerd het upgradingsproces te molelleren. In deze analyse word geprobeerd de verschuiving in de opleidingsachtergronden van de werkenden in de diverse beroepsgroepen te verkjaren uit enerzijds de witgaven ain researdh and development (R\&D) en informatie- en communicatie-technologie (ICT), en anderzijds de opleidingsstructum van lect atheiclsatumbol

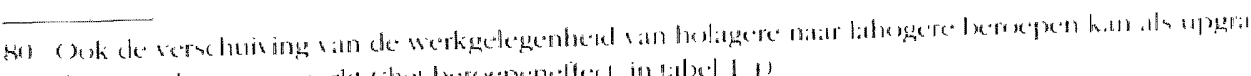

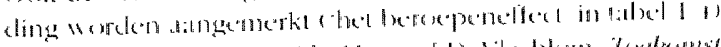

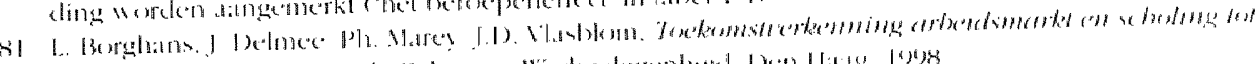

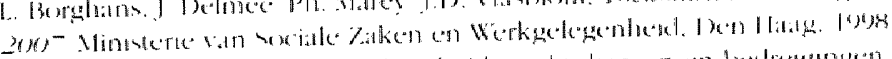

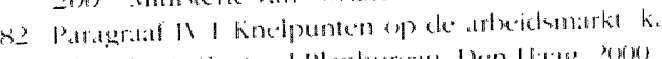

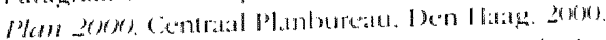

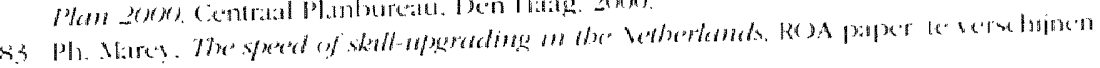


Dit laatste indiceert de mate waarin de hogere opleidingsachtergronden van de werkenden binnen beroepen het gevolg is van een verdringingsproces. Door een aanbodoverschot van hoger opgeleiden verdringen deze de lager opgeleiden uit hun traditionete beroependomein .

Het blijkt dat de gestage groei van het relatieve aanbod van hoger opgeleiden een belangrijke bijdrage heeft geleverd aan de stijging van het opleidingsniveau van de Nederlandse werkgelegenheid gedurende de periode 1969-1993. In deze periode is het toenemende opleidingsniveau van de werkenden in veel beroepen derhalve met name het gevolg geweest van een verdringingsproces. Dit heeft geresulteerd in een neerwaartse tendens van cle relatieve lonen van hoger opgeleiden. Vanaf 1986 gaat de toename van het aantal hoger opgeleiden echter niet langer gepaard met een dalend loon, maar met een hogere beloning. Dit geeft aan dat er vanaf dat moment niet langer sprake is van een verdringingsproces, matr van een toenemende vraag naar hoger opgeleiden. met andere woorden: een upgrading van de kwalificatie-eisen. Tegelijkertijd vinden er aan de vragzijde technologische veranderingen (R\&D en ICT) plats die een opwaarts affect hebben op zowel de relatieve werkgelegenheid als de relatieve lonen van hoger opgeleiden. Als het relatieve aanbod van hoger opgeleiden zou gaan dalen in de toekomst, zullen deze technologiefactoren naar verwachting een belangrijke rol blijven spelen bij de toename van hel opleidingsniveau van de Nederlandse werkgelegenheid.

Verder blijkt dat nalmate bedrijfssectoren meer uitgeven aan R\&D, de vraag naar hoger opge] eiden groter wordt ten koste van de vraig naar middelbaar en lager opgeleiden. Uitgaven aan ICT leiden darentegen vooral tot een toename in de vratag naar middelbatar en hoger opgeleiden ten koste van lager opgeleiden en ongeschoolden. De effecten van R\&D zijn op de korte termijn iets sterker clan op de langere termijn. Dit suggereen dal het clirecte effect - een toename in het atantal R\&D-werkers - sterker is dan het indirecte effect via een toenemend aantal hoger opgeleiden in de productieafelelingen. Dit latste effect zal immers naar verwachting met enige vertraging platsvinden. 1)e effecten van ICT komen datrentegen pas lot witing op de lange termijn. Dit koml wallschijnlijk doordau cen voortschrijclencle diffusie van informatie- en communicallic-technologicën med zich mee brengl dat er organisallorische veranderingen op

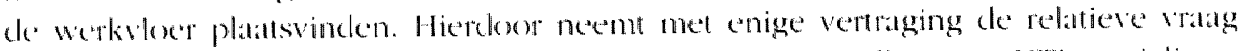

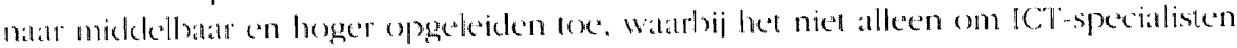
gital.

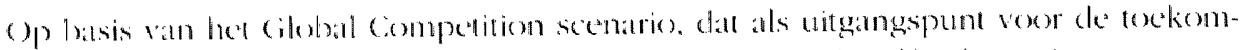

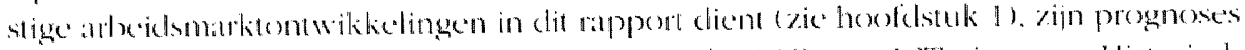

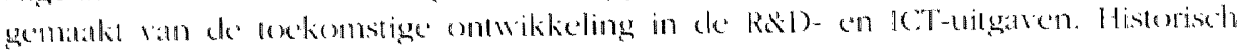

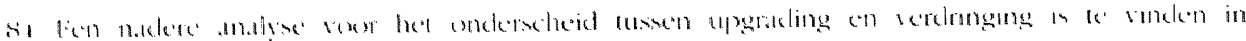

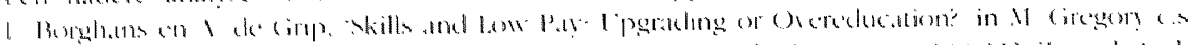

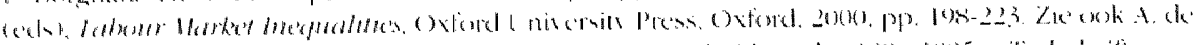

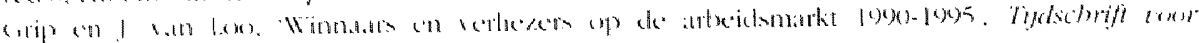

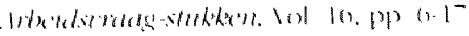


gezien zijn R\&D-uitgaven aanmerkelijk meer variabel dan ICT-uitgaven en vormen derhalve de belangrijkste oorzaak van veranderingen in de snelheid van het upgradingsproces. Het Global Competition scenario kenmerkt zich door snelle technologische ontwikkelingen. waarbij voor de periode 2001-2006 wordl uitgegaan van een sterke toename van R\&D-uitgaven. Ten aanzien van de ICT-uitgaven wordt uitgegaan van de groeisnelheid in het verleden.

Met name de verwachte verhoging van de R\&D-uitgaven inzal de komende jaren draingt derhalve bijdragen aan een grotere vraag naar hoger opgeleiden ten koste van de vraik naar middelbaar en lager opgeleiden. Dit is af te lezen wit het opleidingseffect in tabel 1.4 van hoofdstuk 1 . Zonder de positieve bijdrage van de hogere R\&D-uitgaven aan de upgradingssnelheid, zou het positieve opleidingseffect voor $\mathrm{HBO}$ en $W O$ minder groor zijn, en het opleidingseffect voor $H A V O / V W O, M B O, V M B O$ en basisonderwijs (nog) lager uitvallen. Daarmee draagı de hogere upgradingssnelheid in de periode 2001-2006 substantieel bij aan de verwachte grote knelpunten op de arbeidsmarkt voor hoger opgeleiden.

\section{Kenmerken van het personeelsbestand in beroepsklassen}

De verschillen in vervangingsvraag tussen beroepsklassen en opleidingcategorieën (zik" hoofdstuk 2) worden voor een belangrijli deel bepald door de leetrijdsoplouw van de werkenden $^{\text {ni }}$. De toenemende vergrijzing van de werkzame bevolking heeft, met name" in beroepen met een relatief oud personeelsbestand, hatr weerslag op de uitstrom van de arbeidsmarkt. De uitstroom van werkenden leidt niet tot vervangingsvratig in beroepsgroepen met een dalende werkgelegenheid. Een andere lactor die van helang is, en veelal tot vervangingsvraag leidt, is de anwezigheid van relatief veel vrouwen binnen een beroep. Indien vrouwen kinderen kriigen en vervolgens de opvoeding en andere zorgtaken voor een groot deel voor hun rekening nemen, resulteert dat in veel gevallen in een tijdelijke arbeidsmarktuittrede.

Tabel 5.2 geeft per beroepsklasse het percentage verowen en ouderen onder de werr kenclen weer. In sommige beropepklassen bestiat het personed voomamelijk til man-

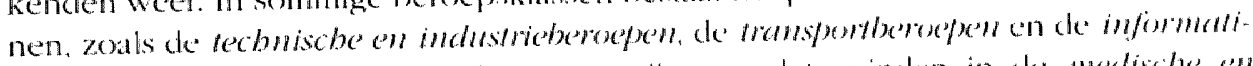

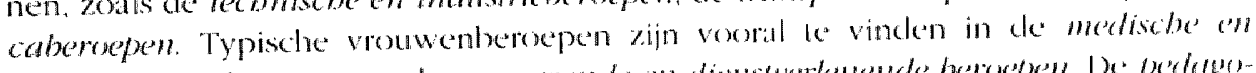

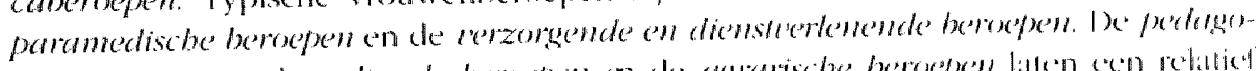

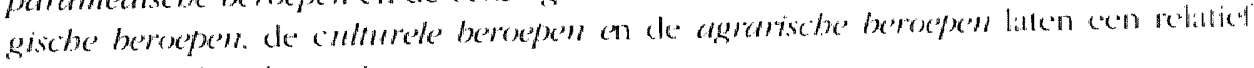
groot a andeed ouderen zien

Op basis van tabel 5.2 kan ecen relatie worden geleged ussen de vergrijging in leel per-

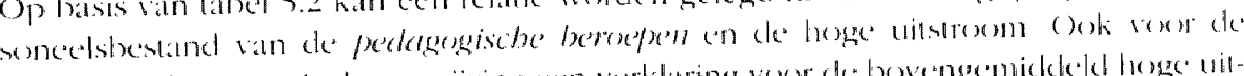

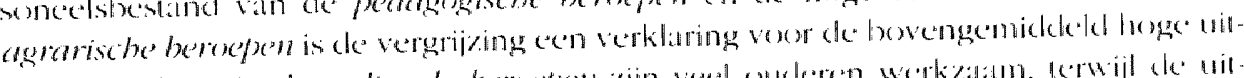

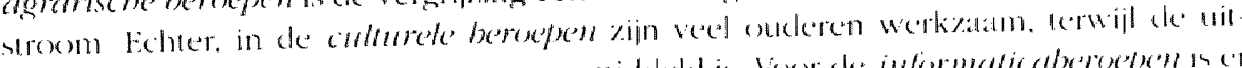

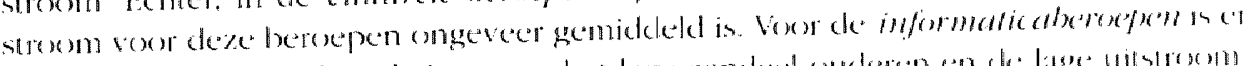

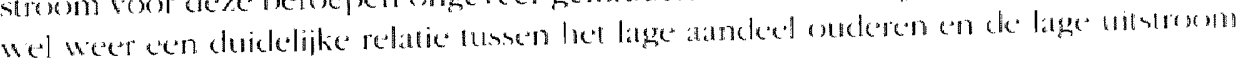

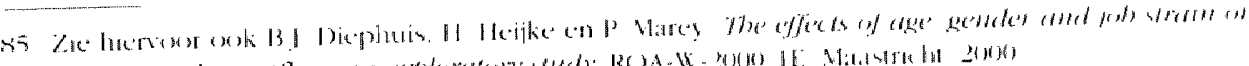

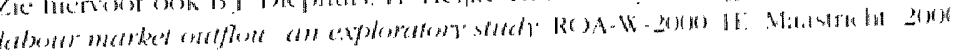


Uit de tabel wordt duidelijk dat een bovengemiddeld (c.q lager dan gemiddeld) aancleel ouderen niet vanzelf betekent dat de uitstroom bovengemiddeld (c.q. lager dan gemiddeld) is. Dit is het geval voor 6 van de 11 beroepsklassen. Hetzelfde gaat ook op voor het aandeel vrouwen per beroepsklasse $\mathrm{ZO}$ is hel alandeel vrouwen in de mediscbe en paramedische beropen erg hoog, en is tevens de uitstroom hoger dan gemiddeld. In de verzorgende en dienstvertenende beroepen is het aandeel vrouwen echter bijna even hoog, terwijl daar de uitstroom lager is dan gemiddeld

Hoewel de verdeling van werkenden naar leefrijd en geslacht zonder meer samenhangt met de vervangingsvragg en uitstroom naar beroep, zijn er vele andere factoren medebepalend zijn. Deze hebben betrekking op o.a. de geboden mogelijkheden voor vervroegde uittreding, de looplyanpatronen die werkenden in hun beroepscarrière kunnen doormaken, de aantrekkelijkheid van beroepen wat betreft de arbeidswoorwarden, de kans op uittrede door arbeidsongeschiktheid vanwege ongunstige arbeidsomstandigheden.

'label 5.2

Vrouwen en ouderen (50-64 jaar) naar beroepsklasse, als percentage van de werkgelegenheid, gemiddelde 1999-2000, en uitstroom, gemiddeld jaarlijks percentage van de werkgelegenheid, 2001-2006

Beroepsklasse

$\begin{array}{rrr}\text { Vrouwen } & \text { Ouderen } & \text { Uitstroom } \\ \% & \% & \%\end{array}$

Pedayogische beroejen

culturte beroepen

Agrarische beroepen

Techuische en industrieberoepen

'Trumspontheroepen

Medische en paramedische beroepen

Fonomisch-administratice beroepen

Informaticalertoepen

Sickiatil-cullurele berween

Ver\%orgunde en dienswarlenende beroepen

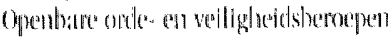

"lotititl

$\begin{array}{rrr}56 & 27 & 4,2 \\ 46 & 25 & 3.1 \\ 26 & 27 & 4,6 \\ 9 & 19 & 3.3 \\ 11 & 20 & 2.7 \\ 73 & 16 & 3.5 \\ 48 & 19 & 3.2 \\ 12 & 9 & 1.8 \\ 61 & 17 & 2.4 \\ 69 & 15 & 2.9 \\ 14 & 13 & 3.3 \\ & & 3.2\end{array}$

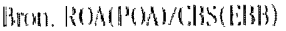

Arbeidsomstandigheden ${ }^{\text {sto }}$

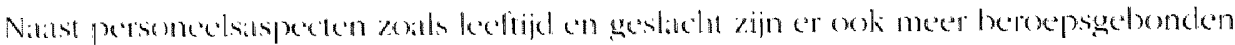

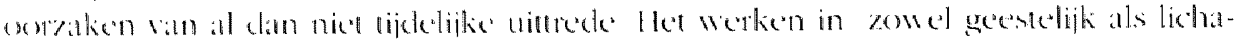

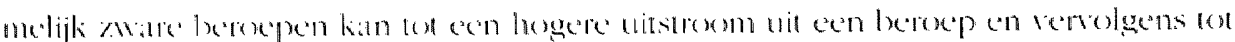

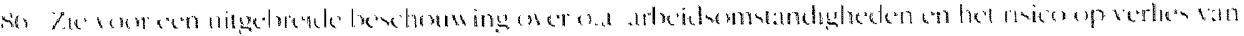

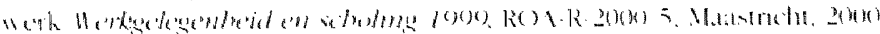


vervangingsvraag leiden. Er kan in dit geval sprake zijn van te zwate belasting resulterend in bijvoorbeeld letsel of 'repetitive strain injury' (RSI), maar ook in gecstelijke wilputting of "burnout'. In sommige gevallen slaagt een werknemer er in samensprak met de werkgever in de werkplek aan te passen of anderszins alternatieve werkzaamheden binnen het bedrijf te vinden. In andere situaties zal de werkende elders, bij een andere werkgever of in een minder belastend beroep. emplooi trachten te vinden. Diarnatast is er een kans op (tijdelijke) uittrede van de arbeidsmarkt door arbeidsongeschiktheid.

Karasek en Theorell onderscheiden twee tactoren die werkgerelateerde stress verootzaken of verergeren. Enerzijds speelt de werkinhoud (lichamelijk zwaar, gevaarlijk, monotoon. hoge werkdruk, etc.) een rol en anderzijds zijn de mogelijkheden van de werknemer om met deze invloeden om te gaan van belang. Deze zogenatamde controls" geven de mate van vrijheid van de werknemer aan die hem in staat stellen rust of afstand te nemen van de vervelende en negatieve aspecten van het werk. Dit leidt tot de schijnbare tegenstelling dat veel leidinggevenden minder stress zeggen te ondervinden dan hun ondergeschikten. De verklaring van deze paradox ligt erin dat persomen in hogere posities weliswar te maken hebben met een hogere werkdruk, maar dall hen ook meer mogelijkheden ter beschikking statan om hiermee om te gaan. De vrijheid om zelf de tijd in te kunnen delen in plats van zich te moeten conformeren atan strak opgelegde werkplanningen biedt managers en bedrijtshoofden veelal meer soelats in het omgalan met stressvolle invloeden. Hierdoor zou hun uittrede beperkt kunnen blijven.

In tabel 5.3 is in beeld gebrach in welke mate de werkenden in de verschillende beroepsklassen geconfronteerd worden met belastende arbeidsomstandigheden. Fir worden zes arbeidsomstandigheden onderscheiden: het werken in een lawailige omgeving, het werken met trillend gereedschap, het krach moeten zetten tijkens het werk, het werken in ploegendiensten, het werken onder rijdsdruk, en het verridnten van beeldschermwerk (computers etc.). Feitelijk kunnen deze zes indicatoren in lwee groepen worden verdeeld. De eerste vier (lawaai, trillend gereedschap, kracht zetten en plexgendienst) duiden op lichamelijk zwatre omstandigheden, terwijl tijdsdrok en beeldschermwerk indicatief zijn voor mentat zware omstandigheden. De lichannelijk

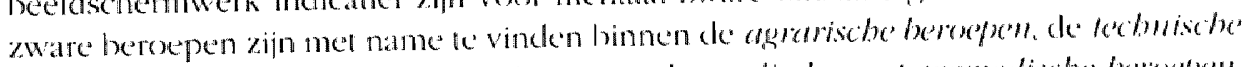

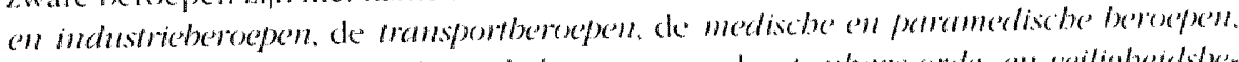

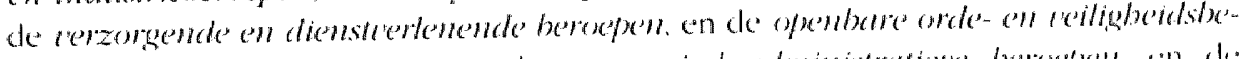

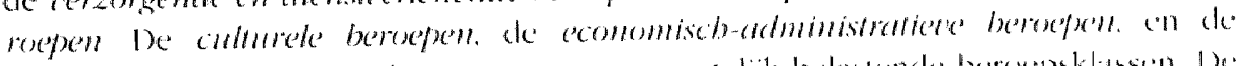

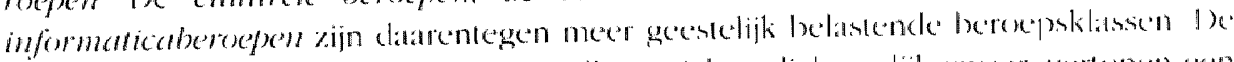

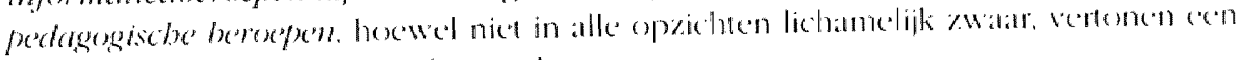
hoge matle van lawald tijdens hel werk

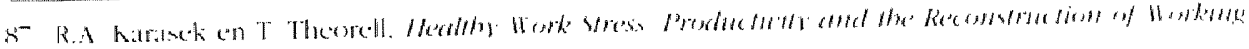

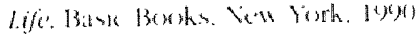


Tabel 5.3

Voorkomen van arbeidsomstandigheden naar beroepsklasse, 1998

Beroepsklasse

Pedagogische beroepen

Culturele beroepen

Agrarische beroepen

"Technische en industrieberoepen

"Transportberoepen

Medische en paramedische beroepen

liconomisch administratieve

beroepen

Informaticaberoepen

Socialal-culturele beroepen

Verzorgende en dienstwertenende

beroepen

Openbare ofde en veiligheids-

beroepen

Totala

Bron: CBS(EBB) / ROA(POA)

$\begin{array}{rrr}\text { Lawaal } & \begin{array}{r}\text { Trillend } \\ \text { gereed }\end{array} & \begin{array}{r}\text { Krach } \\ \text { zetten }\end{array} \\ \% & - \text { schap } & \% \\ \% & \% & \% \\ 28 & 3 & 12 \\ 11 & 2 & 14 \\ 25 & 29 & 6 \\ 46 & 39 & 55 \\ 26 & 12 & 60 \\ 10 & 6 & 44\end{array}$

\begin{tabular}{rrr}
$\begin{array}{r}\text { Ploegen- } \\
\text { dienst }\end{array}$ & \multicolumn{1}{c}{$\begin{array}{c}\text { Beeld- } \\
\text { schem }\end{array}$} \\
$\begin{array}{rrr}\% & \% & \% \\
1 & 59 & 59 \\
3 & 70 & 85 \\
2 & 44 & 25 \\
15 & 60 & 41 \\
20 & 60 & 22 \\
24 & 72 & 60\end{array}$
\end{tabular}

$8-1-8$

$5-2-5$

11

14

20

10

13
55

30

34
68

21

77

67

51

60

80

4

10

12

42

10

62

58

Van belang is verder dat met name een combinatie van factoren de kans op uitstroom door langclurige ziekte of arbeidsongeschiktheid vergroot. Zo kan bijvoorbeekl een hogere leeftijd in combinatie met fysiek belastende omstandigheden een risicofactor zijn. Een hoge werkdruk zal sneller tot (tijclelijke) uitstroom leiden als de arbeidsverhoudingen binnen het bedrijf verstoord zijn. Door de complexiteit van verschillende soms met elkatar samenhangende arbeidsomstandigheden kunnen klachten als RSi zich pas voordoen nadan de werkdruk over een langere tijdsperiode aanhoud. Hel bovenstatande betekent onder meer dat het moeilijk is om een directe relatie zichubatr te maken lussen het vertrek van werkenden wit een beroepsklasse en de ard exidsomstandigheden watin ze verkeren

Voortijdig schoolverlaters

I lit hooldistuk 2 is gebleken dal de verwathe instroom op de arbeidsmarkt van schoolverlaters met als hoogst voltooide opleiding bosisonderuijs. TMBO theorie of HAOM $110 \mathrm{Crg}$ groot is. Fen belangrijke verklaring hiervor is dat het overgrote deel van dexe schoolverlaters wel atan een hogere vervolgopleiding in het reguliere onderwijs begint. matar deze niet met een diploma kan afsluiten

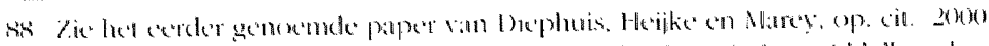

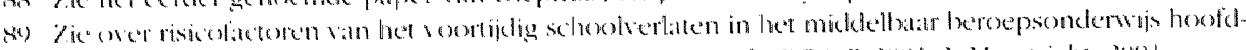

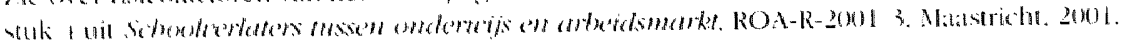


Tabel 5.4.

Arbeidsmarktinstroom van voortijdig schoolverlaters naar hoogste voltooide opleidingstype, als gemiddeld percentage van totale jaarlijkse arbeidsmarktinstroom, 2001-2006

\begin{tabular}{|c|c|c|}
\hline & $\begin{array}{l}\text { Ongediplomeerd } \\
\text { vervolgopleiding } \\
\text { verlaten }\end{array}$ & $\begin{array}{l}\text { Totale } \\
\text { arbeidsmarkt- } \\
\text { instroom }\end{array}$ \\
\hline & $\%$ & aantal \\
\hline Basisonderwijs & 69 & 27.000 \\
\hline VMBO theorie & 92 & 23.400 \\
\hline HAVO/NWO & 56 & 40.10 \\
\hline
\end{tabular}

Bron: ROA(POA)

Tabel 5.4 geeft aan dat $69 \%$ van de arbeidsmarktinstroom van schoolverlaters met als hoogst voltooide opleiding basisonderwijs", een 'drop out' uit het vervolgonderwijs is. De meeste van deze drop outs beginnen aan VMBO. HAVO/VWO of MBO, mar maken deze opleiding niet af. De 'drop outs' die VMBO theorie als hoogst voltooide opleiding hebben afgesloten, is maar liefst $92 \%$ van de totale arbeiclsmarktinstroom van schoolverlaters met $V M B O$ theorie. Een groot gedeelte hiervan is gestopt na het afronden van het derde leerjaar HAVO/VWO. Het percentage 'drop outs' dat HAVO/VWO als hoogst voltooide opleiding heeft afgesloten, is $56 \%$ van de totale arbeidsmarktinstroom van schoolverlaters met HAVO/VWO. De schoolverlaters van de HAVO die door gatan leren maar de opleiding niet afronden, volgen meestal een HBO-opleiding (economie. sociaal agogisch en pedagogiek), mar ook wel een $\mathrm{MBO}$-opleiding (wooral MBO oconomie). Van de schoolverlaters met VWO als hoogst voltooide opleiding heblen de meeste 'drop outs' een WO-opleiding voortijdig afgebroken.

\section{Post-initieel onderwijs}

Zoals hierboven opgemerkt, gaat een groot deel van de schoolverlaters met als hoogst voltooide opleiding basisonderwijs, VMBO theorie of HAVOVWWO een post-initiële ver-

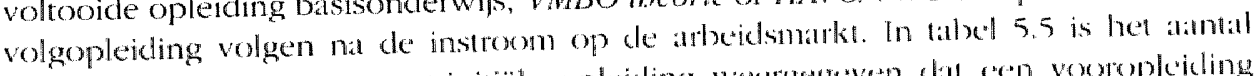
schoolverlaters van een post-initielle opleiding weergegeven dat een vooropleiding

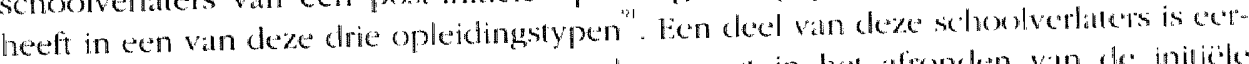
der in de schoolloopbaan nied succesvol geweest in het afronden van de iniliek vervolgopleiding. Het post-initiële onderwijs biedt an de\% drop outs' exn twede kans terwijl zij reeds op de arbeidsmarkt participeren".

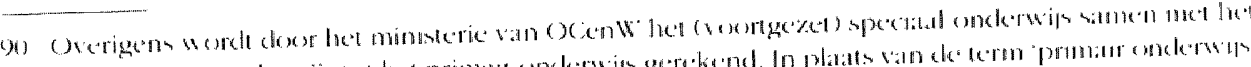

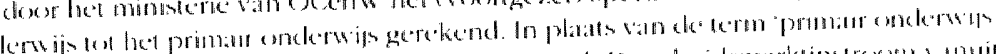

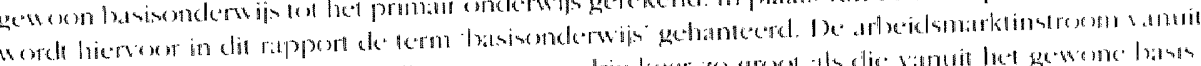

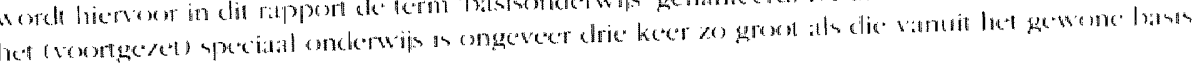
onderais

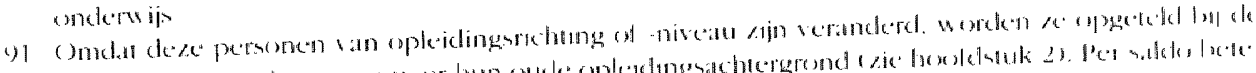
2.8.

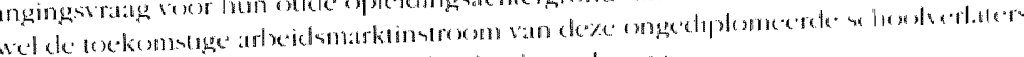

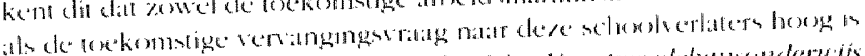


Tabet 5.5

Gediplomeerde schoolverlaters van het post-initiële vervolgonderwijs naar vooropleiding, gemiddeld jaarlijks, 2001-2006

Opleidingstype

Aantal

Basisonderwijs

25.000

13.000

20.500

MMBO theorie

Bron: ROA(POA)

Tegenover het relatief grote aantal "drop outs' dat op de arbeidsmarkt instroomt met één van drie hierboven genoemde opleidingstypen (ca. 62.500, zie tabel 5.4), staan jaarlijks ongeveer evenveel personen die een vervolgopleiding met succes afsluiten (ca. 58.500). Daarmee lijkt het post-initiële onderwijs een zeer belangrijke functie te vervullen om 'clrop outs' betere perspectieven op de arbeidsmarkt te bieden. Vanwege de omvang van deze groep is het van belang na te gaan hoe het arbeidsmarktperspectief van cleze schoolverlaters is veranderd. In tabel 5.6 is dat weergegeven aan de hand van de verdeling van toekomstperspectieven van schoolverlaters met een post-initiële opleiding ten opzichte van hun toekomstperspectieven als ze cleze vervolgopleiding niet zouden volgen. In het algemeen blijken meer schoolverlaters na het volgen van een post-initiële opleiding een goed tot zeer goed toekomstperspectief te hebben dan zij met hun vooropleiding zouden hebben gehad.

Tabel 5.6

Indicator toekomstig arbeidsmarktperspectief van schoolverlaters met post-initiële opleiding ten opzichte van hun vooropleiding, 2001-2006

$\begin{array}{lrrrrr} & \begin{array}{r}\text { zeer goed } \\ \%\end{array} & \begin{array}{r}\text { goed } \\ \%\end{array} & \begin{array}{r}\text { redelijk } \\ \%\end{array} & \begin{array}{r}\text { matig } \\ \%\end{array} & \begin{array}{r}\text { slecht } \\ \%\end{array} \\ \text { Vocropleidling } & 7 & 22 & 30 & 36 & 5 \\ \text { Post-lnitieille opleding } & 10 & 43 & 19 & 25 & 3\end{array}$

Brom: ROA $(\mathrm{P} O \mathrm{ON})$

len slette is in tabel 5.7 het toekomstig arbeidsmatkiperspectief voor de schoolverlaters van post-initiële ten opzichte van schoolverlaters van initiële opleidingen weergegeven. l lieruil blijki dat de schoolverlaters door hel volgen van een post-initële opleiding een beter toekomstperspertief heloben dan de schoolverlaters die een initièle opleiding hebben gevolgd. Een verklaring hiervoor zou kunnen zijn dat de post-initiële opleidingen worden bekostigd door individuete personen en bedrijven, watrdoor bij de heslissing vin hey volgen vin een dergelijke opleiding een betere kosten-baten afweging workte gemalakt datn bij de initieble opleidingen. Dit impliceert dat de pest-initiele opleidingen gemideleld meer malkiconform zijn dan cle inirièle opleidingen

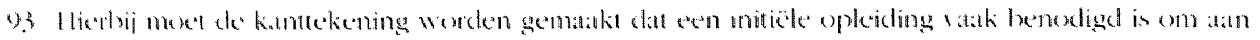

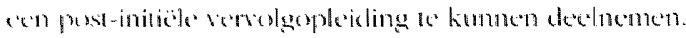


Tabel 5.7

Indicator toekomstig arbeidsmarktperspectief van schoolverlaters met een post-initiële ten opzichte van een initiële opleiding, 2001-2006

zeer goed goed redelijk matig slecht

$\%$

\%

Initiële opleiding

$8 \quad 30$

30

$\%$

$\%$

$\%$

Post-initiële opleiding

10

43

23

31

8

Bron: $\operatorname{ROA}(\mathrm{POA})$ 


\title{
Bijlage A. Enkele centrale begrippen"
}

\begin{abstract}
Allochtoon
Het begrip allochtoon wordt in dit rapport gehanteerd volgens de (oude) CBS-definitie. Deze definitie houdt in dat iedereen die een niet-Nederlandse nationaliteit bezit, of clie buiten Nederland is geboren, allochtoon is. Van speciaal belang vanuit beleidsoogpunt zijn de allochtonen uit de landen die genoemd worden in de Wet Bevordering Evenredige Arbeidsdeelname Allochtonen (WBEAA). Deze landen zijn: Aruba, Nederlandse Antillen, Ethiopië, Inak, Iran, voormalige Joegoslavië, Marokko, Somalië. Suriname, Turkije en Vietnam. Op grond van deze wet zouden echter ook kinderen van allochtonen tot de doelgroep gerekend moeten worden, ongeacht zij een nietNederlandse nationaliteit bezitten.
\end{abstract}

\section{Arbeidsmarktinstroom van schoolverlaters}

Het aanbod van nieuwe arbeidskrachten op de arbeidsmarkt, zoals deze is bepatal door de verwachte uitstroom van schoolverlaters uit het initielle dagonderwijs de schoolverlaters van het deeltijdonderwijs, het niet-reguliere voltijdonderwijs en de* beroepsgerichte volwasseneneducatie.

\section{Publicaties:}

H. Berendsen, R.J.P. Dekker, A. de Grip, P.J.E. van de Loo, Prognose arbesdsmarktinstroom van schoolverlaters per opleidingstype. ROA-W-1992/2, Maastricht.

A. de Grip, A. Jacobs. De doorstroom van bet initieel naar bet niet-initied onderwijs. ROA-W-1999/3, Maastricht.

\section{Arbeidsvolume}

Het totaal atantal arbeidsjaren, watrbij is uitgegatan van een werkweck van 40 uut

\section{Baanopeningen}

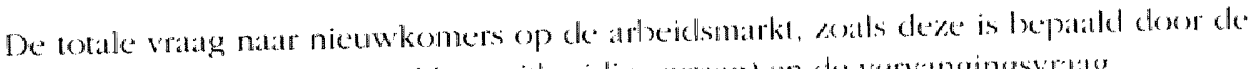
werkgelegenheidsgroei (positieve uithereingswatig) en de vervangingswatitg.

\section{Bedrijfssector}

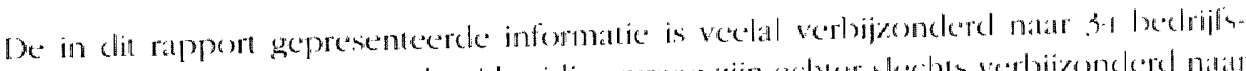

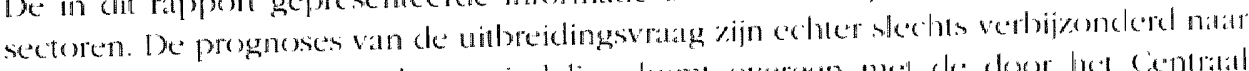

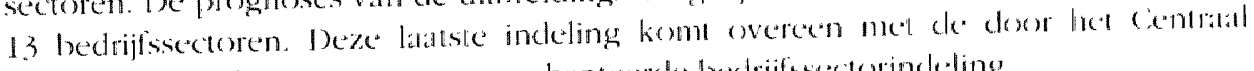
Planbureau bij de sectorprognoses gehantecerde bedriffssectorindeling

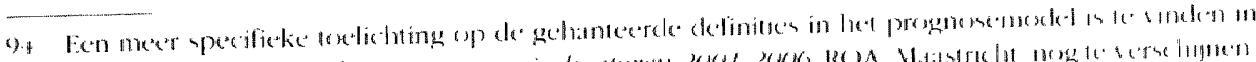

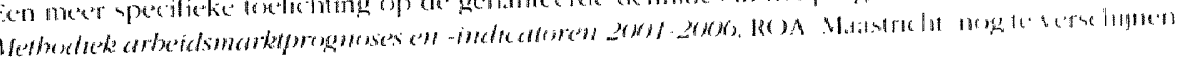




\section{Beroepsgroep}

In dit rapport wordt uitgegatan van 127 beroepsgroepen. Deze kunnen verder worden geclusterd tot 11 beroepsklassen.

\section{Publicatie:}

Centraal Bureau voor de Statistiek, Standaard Beroepenclassificatie 1992, SDU. Den Haag, 1993.

\section{Beroepsbevolking}

De beroepsbevolking omvat de werkenden en de werkzoekenden zonder baan. ledereen met een leefijd tussen de 15 en 64 jaar, die minstens 12 uur per week betaalde arbeid verricht of zou willen verrichten wordt tot de beroepshevolking gerekend. Als men reeds meer dan 12 uur per week werkt, wordt men tot de werkzame beroepsbevolking gerekend. Werkt men niet of minder dan 12 uur, maar wil men wel minstens 12 uur per week betalde arbeid verrichten, dan behoort men tot de werkloze beroepsbevolking.

\section{Publicatie:}

Central Bureau voor de Statistiek, Enquête Beroepsbevolking 1999, Voorburg/Heerlen. 2000.

\section{Conjunctuurgevoeligheid}

De conjunctuurgevoeligheid van de werkgelegenheid heeft betrekking op de mate walain cle werkgelegenheid in een beroepsgroep, of voor mensen met een bepaalde opleidingsichlergrond, gevoelig is vor veranderingen van de economische situatie. Deze indicator geeft datmee de mate van werkzekerheid aan. De conjunctumgevoelighleid word nepalald door de sectorale werkgelegenheidsfluctuaties in hed verkeden te

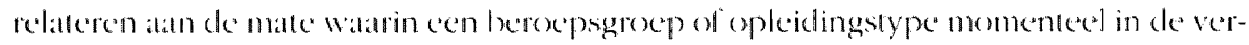
schillende bedriflssectoren is vertegenwordigd. Hierbij word rekening gehouden met

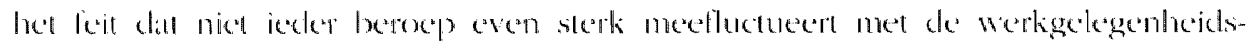

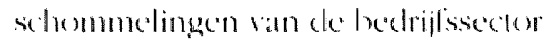

\section{Flexibele arbeidsrelatie}

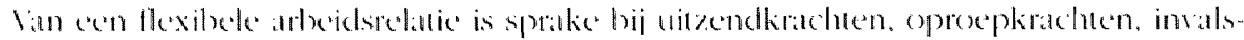

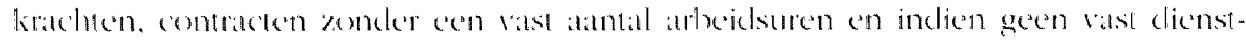

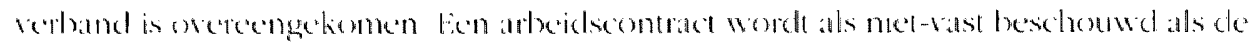

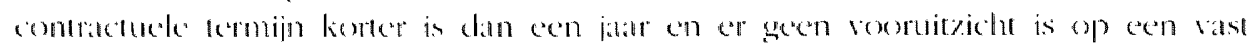
dienstrevilund.

Knelpunten in de personee|svoorziening per beroepsgroep

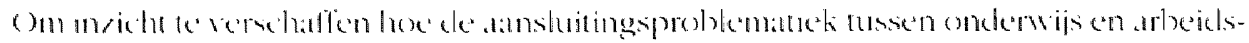

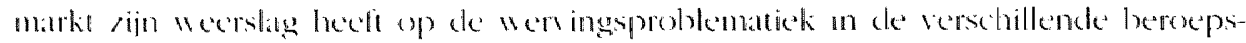

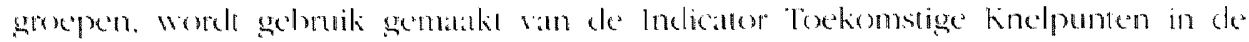


Personeelsvoorziening naar Beroepsgroep (ITKB). De ITKB geeft aan in welke mate het voor werkgevers mogelijk is om de gewenste personeelssamenstelling natar opleidingsachtergrond binnen beroepen te realiseren, bij de voorspelde vraag-aanbod-verhoudingen voor de verschillende opleidingstypen. De ITKB heeft een waarde tussen 0 en 1. Naarmate de warde van de indicator lager is, zijn de knelpunten in de personeelsvoorziening voor de betreffende beroepsgroep groter. Werkgevers zullen dan relatief veel moeite hebben nieuw personeel met de door hen gewenste opleidingsachtergrond te vinden. Wanneer de ITKB daarentegen bijna gelijk is atan 1, zullen werkgevers weinig moeite hebben de gewenste personeelssamenstelling binnen het beroep te realiseren. Voor die opleidingen die aandacht schenken aan de in dat beroep relevante ke'nnis en vaardigheden, worden clan geringe knelpunten verwacht.

\section{Publicatie:}

W. Smits, J. Delmee en A. de Grip, De arbeidsmarkt voor informatici, ROA-R-1998/2, Maastricht.

\section{Knelpunten in de personeelsvoorziening per opleidingstype}

Als de vraag naar werkenden met een bepaalde opleidingsachtergrond groter is diun het aanbod kunnen knelpunten in de personeelsvoorziening verwach worken. Vergelijkbaar met de Indicator Toekomstige Arbeidsmarktsituatie (ITA) geeth de Indicator van de Toekomstige Knelpunten in de Personeelsvoorziening (ITKP) dexe vraag-aanbod-spanning aan. Verschil met de ITA is dat bij cle ITKP de tutstroom van werkenden als gevolg van een krimpende werkgelegenheid is meegerekencl in de vraag, omdat verwacht mag worden dat bij knelpunten in de personedsworomicning deze (gedwongen) uitstroom kan worden afgeremd of elders werk zou kunnen vinden. Naarmate de waarde van de indicator lager word, zijn de verwachte knelpunten groter.

\section{$\overline{\text { Onderbenutting }}$}

Fen indicatie van de mate watrin atheidskrachten werkzatam zijn op een functieniveau clat lager is dan hun oplejdingsniveatu. De mate van onderlenulling is vastgestedel deor de schoolverlaters atan te baten geven in hocverte de werkgever hea verworven opleidingsniveau vereist voor de uitgerefende. funclic.

\section{Publicatie}

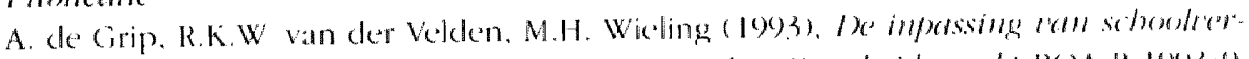
fatersinformatic in bet R(A-informaties) Marasticht

\section{Opleidingstype}

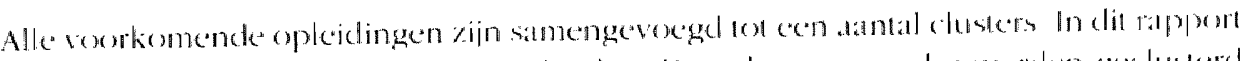

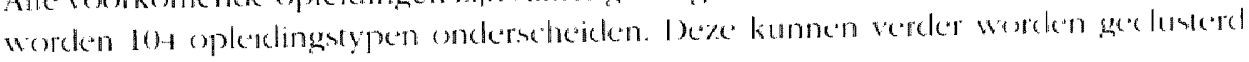

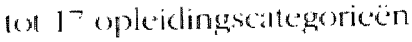

\section{Problicatio.}

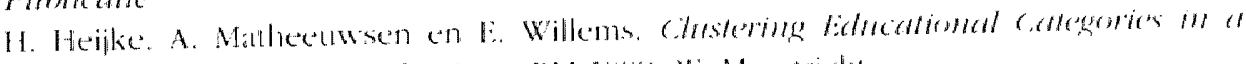

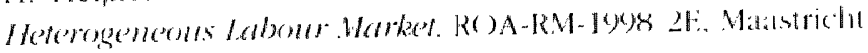


De potentiële beroepsbevolking omvat alle personen tussen de 15 en de 64 jaar, voor zover hun belangrijkste activiteit niet studie betreft. Scholieren en studenten worden dus niet tot de potentiele beroepsbevolking gerekend. De potentiële beroepsbevolking omvat daarmee naast de beroepsbevolking ook de niet-participerenden.

\section{Substitutie-effect (passief en actief)}

Als gevolg van discrepanties tussen vraag en aanbod op de arbeidsmarkt treden er verschurvingen op in de werkgelegenheidsstructuur schoolverlaters in een aanbodoverschotsituatic kunnen anders opgeleiden gaan verdringen, terwijl werkgevers die te kampen hebben met een tekortschietend arbeidsaanbod, personen met een andere opleidlingsachtergrond kunnen gatan werven. De vraag die hierdoor verloren gaat of ontstaat wordt anngeduid als het passieve-substitutie-effect. Als het passieve substitutieeffect positief is, gaat het om extra baanopeningen als gevolg van tekorten bij andere opleidingen. Een negatief substitutie-effect duidı daarentegen op een verlies aan baanopeningen, omdat men verdrongen word door andere opleidingen. Het actieve-substitutie-effect geeft - als het positief is - a an in hoeverre werkenden met een opleidingsachtergrond warvoor er een aanbodoverschot is door een verhevigde concurrentie alsnog werk zullen vinden door arbeidskrachten met een andere opleidingsachtergrond te verdringen. Een negatieve actieve substitutie geeft datrentegen aln welke werkgelegenheid niet meer vervuld zal worden als gevolg van de verwachte aanbodtekorten.

\section{Publicaties:}

L. Borghans en $\mathrm{H}$. Heijke. Forecasting the educational structure of occupations: A manpower reguirement approatch with substitution: Labour, Vol 10. 1994. pp. 151-192.

A. de Grip. L. Borghans. W. Smits, Future developments in the job level and domain of highly-skilled workers', in: H. Heijke, L. Borghans (eds). Touards a transparem labon.

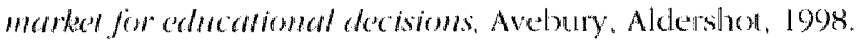

\section{Substitutiemogelijkheden bij de personeelswerving}

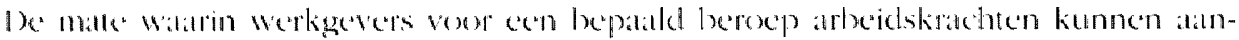

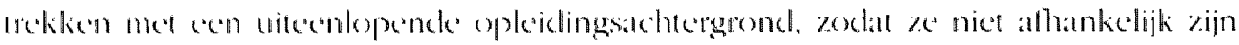

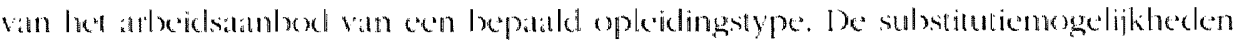
worken bepatal mee beluph ran een spreidingsindex.

\section{Toekomstig arbeidsmarktperspectief}

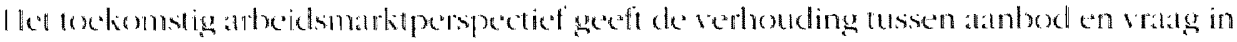

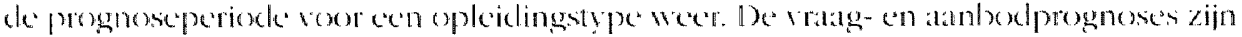

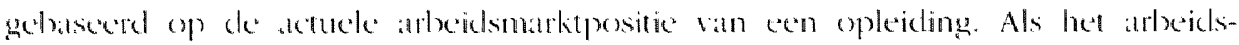

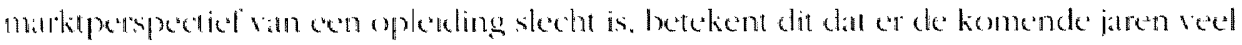

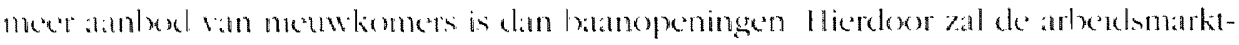

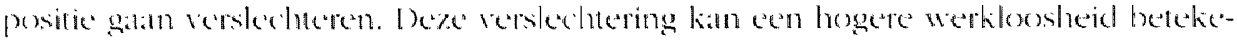

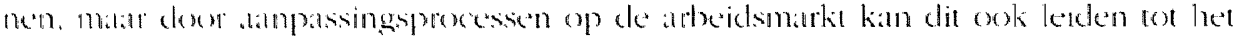

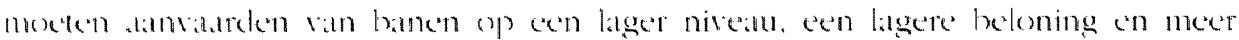


tijdelijke contracten. Omgekeerd zal een goed perspectief tot een grotere kans op werk. maar ook tot een verbeterde positie op andere punten leiden. Het toekomstig arbeidsmarktperspectief per opleidingstype wordt bepaald door middel van de Indicator Toekomstige Arbeidsmarktperspectieven (ITA), die is gedefinieend als de verhouding tussen enerzijds de verwachte arbeidsmarktinstroom van schoolverlaters en het alantal kortdurig werklozen en anderzijds de verwachte baanopeningen en de passieve substitutievraag. Naarmate de waarde van de indicator hoger is word het perspectief slechter.

\section{Publicaties:}

Methodiek arbeidsmarktprognoses en -indicatoren 2001-2006. ROA, Malastricht. A. de Grip en H. Heijke, Bevond Manpouer Planning: ROA s Labour Markel Moded and its Forecasts to 2002, ROA-W-1998-6E, Maastricht.

\section{Uitbreidingsvraag}

De vragg naar nieuwe arbeidskrachten die ontstaat door groei van de werkgekgenheid. Als er sprake is van een werkgelegenheidsdaling, is de uitbreidingsvratg negattict.

\section{Publicalies:}

L. Borghans. H. Heijke. Het loorspellen wan de beroepenstrmatur lam bedrifstakken binnen bet kader van bet Athena-model, ROA-W-1994/L. Malstricht.

A. de Grip en H. Heijke, Beyond Mampower Planning: ROA s' Labour Markel Model and its Forecasts to 2002, ROA-W-1998-6E, Maastricht.

\section{Uitwijkmogelijkheden}

De mate warin arbeidskrachten met een bepaalde opleidingsichtergrond of met exon bepaald beroep terecht kunnen komen in andere beroepsgroepen op een atansluitend of hoger functieniveau, respectievelijk in andere bedriffssectoren. Deze matstal guedi

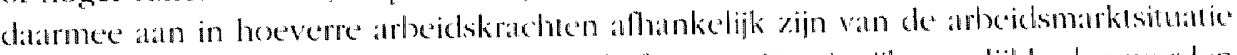

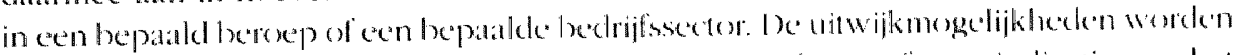

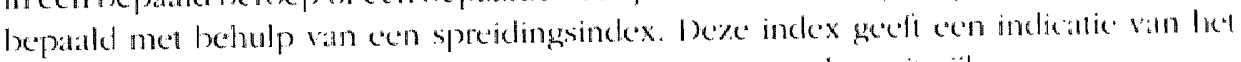
atantal beroepsgroepen of beelrijfssectoren walamatar men kian uitwijke'n

\section{Pablicatie.}

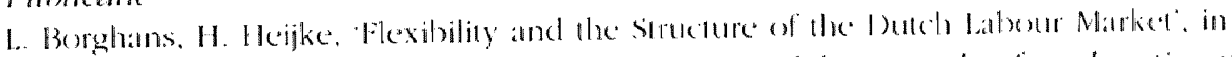

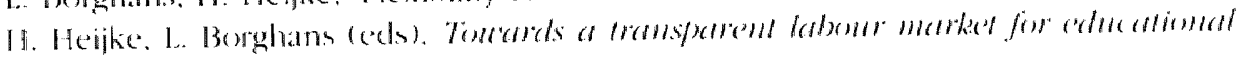
decisums. Andrury. Adelershot. 19)8.

\section{Upgrading}

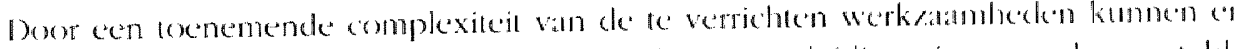

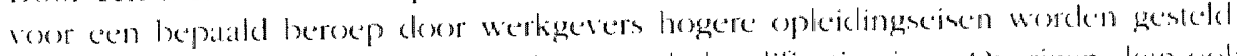
In diat geval spreekt men van upgrading van de kwalificatic-eisen ()verigene kallo on

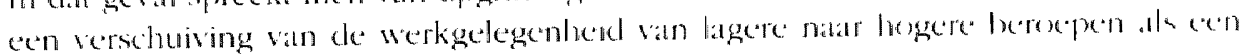
upgradingspreces worden gerypecel 


\section{Publicatie.}

L. Borghans and A. de Grip, Trends in occupations and qualifications: upgrading versus bumping down', in: Burkart Sellin, CEDEFOP (ed.), European trends in the development of accupations and qualifications. Findings of research, studies and analyses for policy and practice, Vol. II, CEDEFOP, Thessaloniki, 1999, pp. 87-102.

\section{Verdringing}

Inclien de arbeidskrachten met een bepaalde opleidingsachtergrond vanwege een aanbodoverschor bij een ander opleidingstype, te kampen hebben met een dalend werkgelegenheidsaandeel in de beroepen waarin zij werkzaam zijn, is er sprake van verdringing. Meer technisch wordt dit ook wel aangeduid als een negatief passief substitutie-effect. Bij het opleidingstype dat de anders opgeleiden verdringt is er sprake van een positief actief substitutie-effect.

\section{Publicatie:}

A. de Grip, L. Borghans, W. Smits, Future developments in the job level and domain of highly-skilled workers', in: H. Heijke, L. Borghans (eds). Towards a transparent labour market for educational decisions. Avebury, Aldershot, 1998.

\section{Vervangingsvraag}

De vraag natr nieuwe arbeidskrachten die ontstaat doordat de arbeidsplatsen van werkenden die met pensioen gaan, arbeidsongeschikt worden of zich (tijdelijk) terugtrekken van de arbeidsmarkt opnieuw moeten worden opgevuld. De vervangingsvratag per beroepsgroep kan bovendien ontstaan cloor de beroepsmobiliteit. De vervangingsvraag natr opleiclingstype kan bovendien ontstatn wanneer arbeidskrachten door middel van niveauverhogende of richtingveranderende scholing aanvullende kwalificaties weten te verwerven. Vertrek van werkenden dat niel leidt tot vaag naar nieuwkomers wit hetzelfde opleidingstype of clezelfde beroepsgroep wordt niet meegerekend als vervangingsvoray.

\section{Publicalies:}

1:J.T.A. Willems, A. de Grip, Forecasting Replacement Demand by Occupaltion and lidecation, International fonmal of forecasting, Vol. 9, 1993, pp. 173-185.

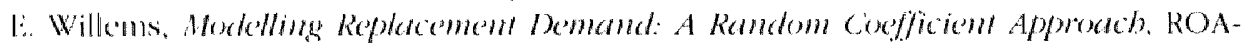
$\mathrm{RM}-1(9) / 2 \mathrm{l}$ : Milatitricht.

\section{Werkloosheid}

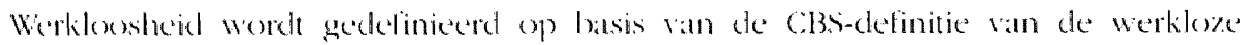
berexpstevelking. Tot de werkiloze beroepstevolking worden gerekend de personen die niet of mincler dian 12 un werken en die:

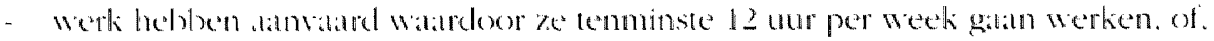

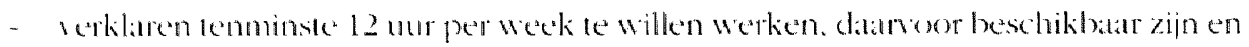
activiteiten ontplosien om werk vor tenminste 12 um per week te vinden 
Het werkloosheidspercentage wordt bepaald door het antal werklozen te relateren aan de beroepsbevolking. Kortdurig werklozen worden gedefinieerd als personen die minder dan een jaar werkloos zijn.

\section{Publicatie:}

Centraal Bureau voor de Statistiek, Enquête Beroepsbevolking 1999, Voorburg/Heerlen. 2000. 


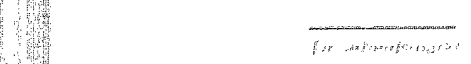




\title{
Bijlage B. Classificaties naar sector, beroep en opleiding
}

\author{
Bedrijfsectoren
}

Landbouw en visserij

Tuinbouw

veehouderij

Akkerbouw, bosbouw en visserij

Voeding

Vlees- en visverwerking

Overige voedingsproducten

Drank en tabaksproducten

Chemie

Basischemie

Eindproducten chemie

Kunststofverwerking

Metaal en elektrorechniek

Basismetaal

Metaalproducten

Machine-industrie

Elektrotechniek

Transportmiddelen

Overige industrie

Texticl

Hout- en bouwmatlerialen

Papier

Grafische inclustrie

\section{Energie}

Energie

Bonue en romererend gend

Bous

Fxplestatie van onrexerend goed

Handel en reparate

Handel en reparatix

Tramspont en commanticalice

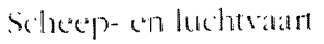

Weg-en rativernoct

Communicatic: 
Bank en verzekeringswezen

Bankwezen

Verzekeringswezen

Horeca en zakelijke dienstverlening

Horeca

Zakelijke dienstverlening

Overige commerciële dienstverlening

Kuartaire diensten

Gezondheidszorg

Overige kwartaire diensten

Overheid en onderwijs

Onderwijs

Overheid

Beroepsklassen en onderliggende beroepsgroepen

Pedagogische beroepen

Leraar basisonderwijs

Docenten exacte, medische en verzorgende vakken ( $2 e$ graads)

Docenten exacte, medische en verzorgende vakken (1e graads)

Docenten landbouw en techniek (2e graads)

Docenten landloouw en techniek (le graads)

bocenten economisch-administratieve vakken ( 2 e graads)

Docenten economisch-administratieve vakken ( 1 e graads)

Docenten talen en expressie

Docenten letteren (le graads)

boconten sociale vakken ( 2 e graads)

Docenten sociale valkken (le graads)

bocenen 20 gratads zonder specialisatie

bocent le gratads ander specialisatic

()nderwijskundig modewerkers

()nclerwijskundigen en pedagogen

Rij-instructeurs

Foweminstructeurs

siportinstructeors

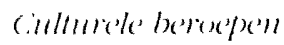

lolken, rentalers en sichrijers

Biblioherekissistenten

Biblionlecartissen

(iratisch ontwerperts

kumstenatas

(icestelijk rergorgers

(ierserelijken

foumalisten

liallimehgen 


\section{Agrarische beroepen}

Agrarische hulparbeiders

Agrarische arbeiders

Agrarische vakkrachten

Milieuhygiënisten en agrarisch vertegenwoordigers

Landbouwkundigen

Landbouwmachinebestuurders en vissers

Agrarische bedrijfshoofden

Technische, ambacbls-en industrieberoepen

Productiemedewerkers

Laboratorium-assistenten

Laboranten

Technisch analisten

Natuurwetenschappers

Conciërges

Hoofden technische dienst

Werktuigbouwkundigen

Bouwvakkers

Aannemers en installateurs

Architecten en bouwkundig projectleiders

Weg-en waterbouwkundigen

Weg- en waterbouwkundige arbeiders

Weg- en waterbouwkundige vakkrachten

Weg- en waterbouwkundig ontwerpers en projectleiders

Metaalarbeiders

Bankwerkers en lassers

Bedrijfshoofden metaalbewerking

Assembleurs

Monteurs

Werktuighouwkundig ontwerpers en hookden lectunische diensl Elektronicamonteurs

Monteurs en controleurs elektrotechnische producten

Elektromonteurs

Elektrotechnisch ontwerpers en lxedriffshootden

Elektrotechnici

(irafisch productiepersonecl

(iralische vakkrachten

Mechanisch operators

processeperators

Procestechnologen

Vateriaalkundigen

Conlecter-arbeiders

shoen-on klecrmakers 
Laders en lossers

Chauffeurs

schippers en conducteurs

Vliegers, scheepskapiteins en leidinggevenden transport

Stewards

\section{Mediscbe en paramedische beroepen}

Verpleeghulpen en leerling-verpleegkundigen

verplegenden en cloktersassistenten

Therapeuten en verpleegkundigen

Artsen

Apothekersassistenten en medisch laboranten

Medisch analisten

Apothekers

Afdelingshoofden zorginstelling

\section{Economisch-administratieve beroepen}

Kantoorhulpen, inpakkers en colporteurs

Ondersteunende administratieve hulpkrachten

Bedriffshoofden

Economen

Productieplanners

Organisattie-adviseurs

Organisatjedeskundigen

Receptionisten en administratieve employés

boekhouders en secretaresses

Assistent accountants

Accountants

Ver\%ckeringsigenten

commerciecel employés

commereded medewerkers

Tirdmischecommerecied employés

Techmisch-bedrijfskundig medewerkers

furidisch en fiscalal medewerkers

Juridisch, lecstumrlijk medewerkers

Juristen

Administrateve tamspertemployes

l.cidinggevenden

Mamigers

Medisch secredaresents

Informatica berespen

Programmenturs

sisteomimatistem

Intermallei

fechnisch sistermamalisten 
Sociaal-culturele beroepen

Activiteitenbegeleiders en medewerkers arbeidsbemiddeling Medewerkers sociaal-cultureel werk en personeel en arbeid Hoofden sociaal-cultureel werk en personeel en arbeid Sociaal-wetenschappelijk medewerkers

Sociaal-wetenschappelijk onderzoekers

Verzorgende en dienstuerlenende beroepen

Vakkenvullers

Interieurverzorgers

Verkopers

Winkeliers

Hulpkrachten horeca en verzorging

Ziekenverzorgenden

Verzorgend personeel

Café- en snackbarhouders

Bedrifshoofden horeca

Bakkers en slagers

Openbare orde- en veiligheidsberoepen

Aspirant politieagenten, soldaten en beveiligingshulpkrachten

Politieagenten, onderofficieren en beveiligingsemployes

Politie-inspecteurs en officieren

Brandweerlieden

Opleidingscategoriën en onderliggende opleidingstypen

Basisondenuijs

Basisonderwijs

IMBO Therric

VMBO theoric

IMBO Landbonte ('n lecblick

VMBO landbouw en naturlijke omgeving

$\checkmark \mathrm{MBO}$ berwedechnick

$\checkmark \mathrm{MlBO}$ installaterectonek

VMBSC metalal mechansehe lectmeck

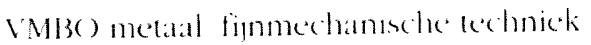

MMBS ) vertuigentechnek

VMBB( ) ekektrotechnek

IMBC grafinche technock

imliso brocel en bankel

vilso transport en logmsticts

VMIB() beveiliging

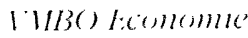

$\checkmark 11 B 30$ admmostratic handel en mode

111830 consumplet en keremidelekntechnek 
VMBO Verzorging

VMBO (uiterlijke) verzorging

HAVONVWO

HAVO/VWO

MBO Landbouw en lechniek

MBO landbouw en veeteet

MBO milieu en groene ruimte

MBO laboratorium

MBO bouw

MBO grond-, weg- en waterbouw

MBO installatietechniek

MBO werktuigbouw en mechanische lechniek

MBO fijnmechanische techniek

MBO motorvoertuigentechntek

$\mathrm{MBO}$ vlicgtuigtechnick

MBO operationele techniek

MBO elektrotechniek

MBO grafische techniek

MBO procestechniek

MBSO brood en banket

MBO levensmicklelentechniek/vleesverwerking

MBO vervoer en logistiek

$\mathrm{MBO}$ atutomatisering

$\mathrm{MBO}$ openbare orde en veiligheid

MBO Economic

MBO aldministratie

MB3( ) handel

MIBO secrelatrian

MIB() loerisme en recreatic

MIS() bedriilskunde

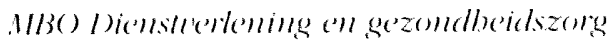

Mlse) doklers-, landatts- en dierenamtsassistent

Mls() apentrekersisststent

MIB( ) rerpleging

MIBC $)$ g( \%ondhe idstechnick

MI3() socitial-cultured

MIBC ) rersorgeng

Nllzo ) wilerlijke veresging

MIB() horecal

Mll3() berweging (n theraple

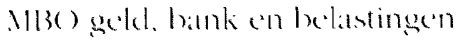

MlBs ) verstictingswe\%n 


\section{HBO Landbouu' en techniek.}

$\mathrm{HBO}$ landbouw en veeteelt

HBO milieukunde en levensmiddelentechnologie

HBO laboratorium

HBO bouwkunde

$\mathrm{HBO}$ civiele techniek

HBO werktuigbouwkunde

HBO elektrotechniek

$\mathrm{HBO}$ informatica

$\mathrm{HBO}$ chemische technologie

$\mathrm{HBO}$ vervoer en logistiek

HBO openbare orde en veiligheid

HBO Economie

HBO accountancy en bedrijfseconomie

$\mathrm{HBO}$ commerciële economie

HBO toerisme en recreatie

HBO recht en bestuur

HBO secretariaat

HBO bedrijfskunde

\section{HBO Onderwijs en sociaal-cultured}

HBO lerarenopleiding basisonderwijs

HBO lerarenopleiding talen

HBO lerarenopleiding natuur en techniek

HBO lerarenopleiding economie en matschappij

HBO lerarenopleiding lichamelijke opvoeding

HBO lerarenopleiding medisch en verzorging

HBO lerarenopleiding expressie

HBO tolk en vertaler

HBO communicattic en journalistiek

HBO maatschappelijk werk en hulpverlening

HBO personeel en arbeid

HBO bibliotheek en clocumentatic

IIBO nitvoerende en beckdende kunsien

IIBC) Peramedisch

IIBO) verplecegkunde

IIB() (lysiontherapic

IIIB( ) rexeding

HBB( ) racliologice

II) Iandbontu en lechnick

II) landbour en mileseukunde

$\mathbb{P}($ ) wiskunde en natuuruedenschappen

Wo bouwkunde

Wo ( ) ivicke le hnick

Wo werkrumghoumkunde 
WO elektrotechnick

WO informatica en bestuurlijke informatiekunde

WO ticonomie

WO econom(etr)ie

WO bedrijfskunde

WO accountancy en belastingen

wO rechten en bestuurskunde

WO Letteren en sociaal-cultureel

wO letteren

WO theologie

WO sociale wetenschappen

WO kunstwelenschappen

WO Medisch

WO (dier)geneeskunde

WO tandheelkunde

WO farmacie en medische biologic 
Per bedrijfssector, beroepsgroep of opleidingstype zijn de hieronder weergegeven variabelen verkrijgbaar. De betreffende arbeidsmarktinformatie is samengesteld in het kader van het Project Onderwijs-Arbeidsmarkt (POA). Bij het Researchcentrum voor Onderwijs en Arbeidsmarkt is per bedriffsector, beroepsgroep of opleidingstype van Bijlage $B$ een tabel te bestellen met de beschikbare arbeidsmarktinformatie.

\section{Bedrijfssectoren}

- aantal werkenden

- percentage vrouwen

- percentage allochtonen

- percentage jongeren (15-29 jaar) en ouderen (50-64 jaar)

- percentage werkenden naar opleidingsniveau

- percentage deeltijdarbeid

- percentage flexibel en vast werk van arbeidskrachten in loondienst

- percentage zelfstandigen

- belangrijkste beroepsgroepen

- belangrijkste opleidingstypen

- conjunctuurgevoeligheid

- verwachte knelpunten op middellange termijn in de personeelsvoorzicning

\section{Beroepsgroepen}

- aantal werkenden

- percentage vrouwen

- percentage allochtonen

- percentage jongeren (15-29 jatar) en oucteren (50-64 jaar)

- gemiddelde leceftijd

- percentage werkenden natar epleidingsnivealu

- percentage dechlijdarlecid

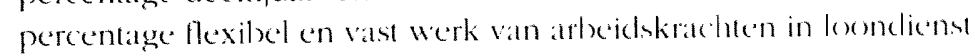

- percentage zelfstandigen

- belangrijkste bedrijtsicectoren

uitwijkmogelijkheden nalat versichillende bedrijtissectoren

belangrijkste opleidingstype

substitutemogelijkheden ussen menenen met uiteentespende.

oplexlingsachtergronden

conjuncturgereselighend

bervakhe uitherelongstratg

rerwatche remangingstrata

rerwache batanopenengen

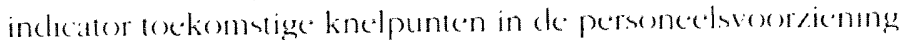


- aantal werkenden

- arberdsmarktpositie potentiele beroepsbevolking

- participatie schoolverlaters in vervolgopleidingen

- percentage schoolverlaters met een intredewerkloosheid van 4 maanden o

- percentage werkloze schoolverlaters

- percentage vrouwen

- percentage allochtonen

- percentage jongeren (15-29 jaar) en ouderen (50-64 jaar)

- gemiddelde leeftijd

- percentage deeltijdarbeid

- percentage deeltijdarbeid onder werkzame schoolverlaters

- percentage flexibel en vast werk van arbeidskrachten in loondienst

- percentage werkzame schoolverlaters met een vast dienstverband

- percentage zelfstandigen

- gemiddeld bruto maandloon van werkzame schoolverlaters

- percentage werkzame schoolverlaters met een functie in de eigen vakricht

- percentage werkzame schoolverlaters van wie kwalificaties onderbenut wo

- belangrijkste beroepsgroepen

- uitwijkmogelijkheden naar verschillende beroepsgroepen

- belangrijkste bedrijfssectoren

- uitwijkmogelijkheden nar verschillende bedrijfssectoren

- overzicht opleidingstypen waarvan op de markt sterke concurrentie wor vonden

- conjuncturgevoeligheid

- verwachte uithreidingsvraag

- verwachte vervangingsvaag

- verwalchte baanopeningen

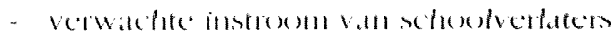

- indicator l(xkomstige arlexidsmarkiperspecteven (ITA) en indicator toe knelpunten in de personectsvoromiening (ITKP) 
